KNOWLEDGE COMMUNITIES

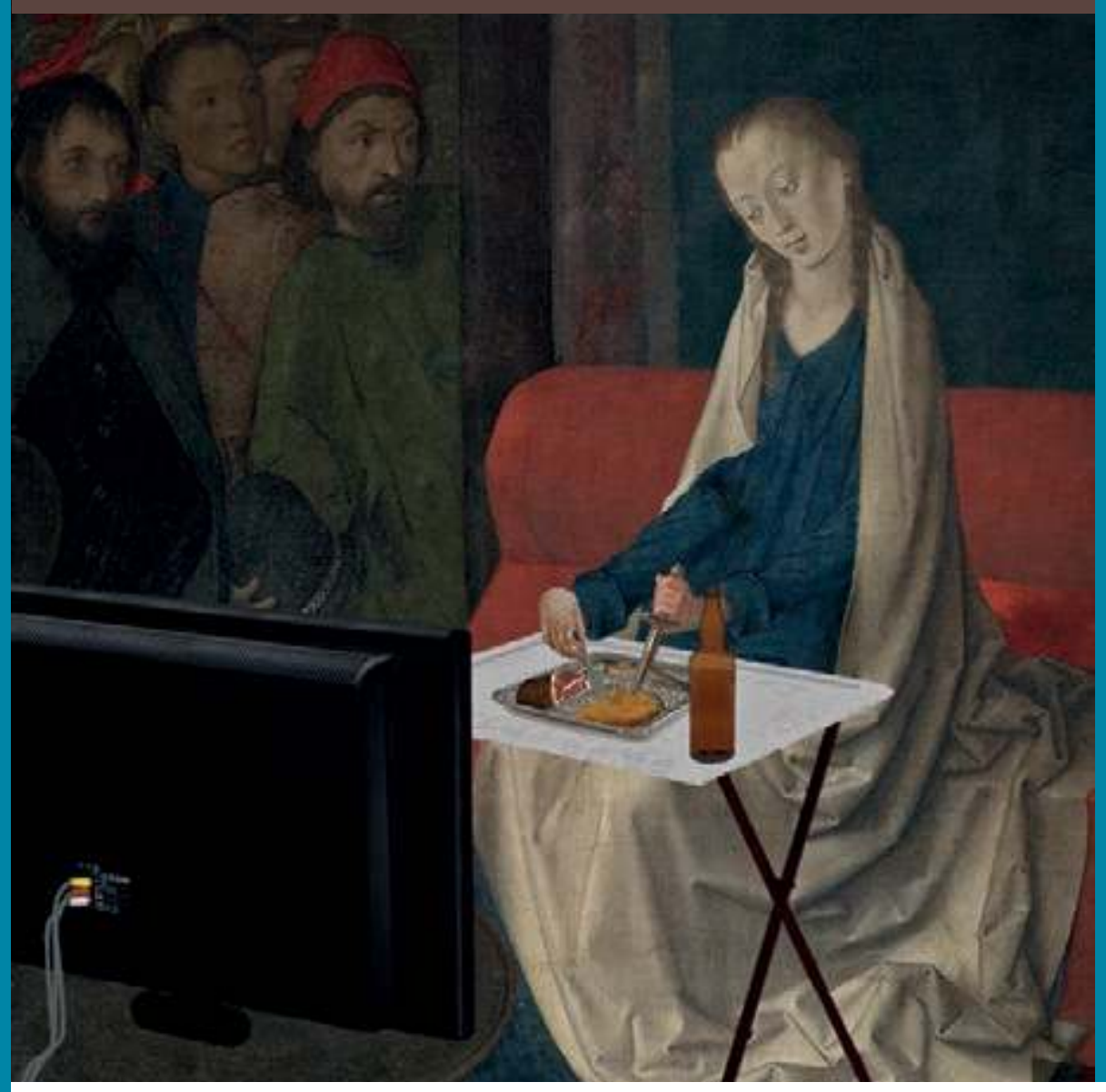

Alicia Spencer-Hall

\title{
Medieval Saints and Modern Screens
}

\section{Divine Visions as Cinematic Experience}


Medieval Saints and Modern Screens 


\section{Knowledge Communities}

This series focuses on innovative scholarship in the areas of intellectual history and the history of ideas, particularly as they relate to the communication of knowledge within and among diverse scholarly, literary, religious, and social communities across Western Europe. Interdisciplinary in nature, the series especially encourages new methodological outlooks that draw on the disciplines of philosophy, theology, musicology, anthropology, paleography, and codicology. Knowledge Communities addresses the myriad ways in which knowledge was expressed and inculcated, not only focusing upon scholarly texts from the period but also emphasizing the importance of emotions, ritual, performance, images, and gestures as modalities that communicate and acculturate ideas. The series publishes cutting-edge work that explores the nexus between ideas, communities and individuals in medieval and early modern Europe.

\section{Series Editor}

Clare Monagle, Macquarie University

\section{Editorial Board}

Mette Bruun, University of Copenhagen

Babette Hellemans, University of Groningen

Severin Kitanov, Salem State University

Alex Novikofff, Fordham University

Willemien Otten, University of Chicago Divinity School 


\title{
Medieval Saints and Modern Screens
}

\author{
Divine Visions as Cinematic Experience
}

Alicia Spencer-Hall 
Cover illustration: Untitled digital collage, by James Kerr (2017)

Source work: 'The Adoration of the Magi', by Justus of Ghent (c. 1465). Distemper on canvas. $43 \times 63$ in. $(109.2 \times 160 \mathrm{~cm})$. Currently held by The Metropolitan Museum of Art (New York); accession number 41.190.21; artwork in the public domain.

Cover design: Coördesign, Leiden

Typesetting: Crius Group, Hulshout

Amsterdam University Press English-language titles are distributed in the US and Canada by the University of Chicago Press.

$\begin{array}{ll}\text { ISBN } & 9789462982277 \\ \text { e-ISBN } & 9789048532179 \text { (pdf) } \\ \text { DOI } & 10.5117 / 9789462982277 \\ \text { NUR } & 684\end{array}$

(C) Alicia Spencer-Hall / Amsterdam University Press B.V., Amsterdam 2018

All rights reserved. Without limiting the rights under copyright reserved above, no part of this book may be reproduced, stored in or introduced into a retrieval system, or transmitted, in any form or by any means (electronic, mechanical, photocopying, recording or otherwise) without the written permission of both the copyright owner and the author of the book.

Every effort has been made to obtain permission to use all copyrighted illustrations reproduced in this book. Nonetheless, whosoever believes to have rights to this material is advised to contact the publisher. 


\section{Table of Contents}

Introduction: Ecstatic Cinema, Cinematic Ecstasy 11

$\begin{array}{lr}\text { The Agape-ic Encounter } & 14\end{array}$

$\begin{array}{lr}\text { Ecstatic Cinema } & 16\end{array}$

$\begin{array}{lr}\text { Cinematic Ecstasy } & 18\end{array}$

The 'Holy Women of Liège'

A Collective Audience $\quad 40$

Cinematic Hagiography $\quad 43$

$\begin{array}{ll}\text { Mysticism and Popular Culture } & 47\end{array}$

Beyond the Frame $\quad 52$

$\begin{array}{ll}\text { Overview of Chapters } & 59\end{array}$

1 Play / Pause / Rewind: Temporalities in Flux 65

$\begin{array}{ll}\text { The Miracle of Photography } & 65\end{array}$

$\begin{array}{ll}\text { Photographic and Sacred Time } & 71\end{array}$

$\begin{array}{ll}\text { Saints as Photographs } & 73\end{array}$

Pressing Play: Cinematic Reanimation(s) $\quad 77$

$\begin{array}{ll}\text { Execution Films } & 79\end{array}$

Resurrection, Resuscitation, and Unfulfilled Promises 83

$\begin{array}{ll}\text { The Purgatorial Body } & 86\end{array}$

$\begin{array}{ll}\text { Liturgical Time } & 91\end{array}$

$\begin{array}{lr}\text { Purgatorial Time } & 96\end{array}$

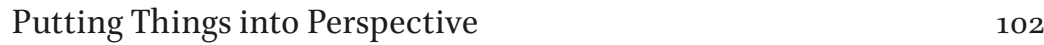

2 The Caress of the Divine Gaze 107

$\begin{array}{ll}\text { Look, and Look Again } & 107\end{array}$

$\begin{array}{ll}\text { Bacon's Synthesis Theory } & 113\end{array}$

Becoming What You See: The Cinesthetic Subject 118

God the Projector 122

Feeling What You See: Sensual Catechresis $\quad 128$

$\begin{array}{ll}\text { The Collective Spectatorial Body } & 131\end{array}$

Coresthesia: Reading, Seeing, and Touching the Corpus $\quad 136$

3 The Xtian Factor, or How to Manufacture a Medieval Saint 147

$\begin{array}{ll}\text { Marie of Oignies, the Celebrity Saint } & 147\end{array}$ 
An Anti-Cathar Poster Girl 152

Marie the Mystical Chanteuse $\quad 156$

Jacques of Vitry, Star Preacher $\quad 15^{8}$

$\begin{array}{ll}\text { Hairdressers to the Stars } & 161\end{array}$

Celebrity Role-Models $\quad 165$

$\begin{array}{ll}\text { Margery Kempe's Fanfictions } & 167\end{array}$

Keeping Up With Kempe 173

$\begin{array}{ll}\text { Fans in the Academy } & 187\end{array}$

4 My Avatar, My Soul: When Mystics Log On 193

Vision, Presence, and Virtual Reality 193

Situating SL: Disentangling Television, Film, and Virtual Worlds 197

The Online Communion of Saints 204

'Logging On' to the Communion of Saints 210

Of Avatars and Offline Bodies $\quad 214$

The Agony and the Ecstasy of Technology 221

Crucifixion Online $\quad 228$

Men, Women, and Heterodoxy 231

Gender-Swapping to Level Up 234

Agency and Dependence $\quad 239$

Conclusion: The Living Veronicas of Liège 243

Unveiling the Veronicas $\quad 243$

Lively Relics $\quad 245$

Bargaining: Agency and Impotence 247

The Other Women, Glimpsed in the Mirror 253

$\begin{array}{ll}\text { Abbreviations } & 255\end{array}$

$\begin{array}{ll}\text { Bibliography } & 259\end{array}$

$\begin{array}{ll}\text { Index } & 292\end{array}$ 


\section{List of Tables and Figures}

Table 1 Corpus summary data 22

Figure $1 \quad$ Map of the Low Countries, c.1100-c.1500 26

Figure 2 Map of the southern Low Countries in the thirteenth century, showing principal towns and regions 27

Figure 3 Dioceses in the southern Low Countries, 1146-1559 28

Figure 4 The first beguine communities in Brabant-Liège $(c$. 1200-c. 1230) 29

Figure 5 'Face of Christ Superimposed on an Oak Leaf', photogenic drawing by Johann Carl Enslen (1839) 66

Figure 6 Radiation through the glacial (or crystalline) humour according to Roger Bacon $\quad 116$

Figure 7 Manuscript illustration of Olibrius the prefect, with abrasions

Figure 8 Manuscript illustration of St. Margaret, unmarked, between two guards, with head and feet erased

Figure 9 Section of manuscript folio, showing text of Augustine's Confessions (left) and medieval commentator's notes (right)

Figure 10 Parchment mitre commissioned by Jacques of Vitry (front)

Figure 11 Parchment mitre commissioned by Jacques of Vitry (back)

Figure 12 Second Life advertisement featuring Avatar-style avatar ('Navitar') from 2010

Figure 13 Author's avatar using a prayer pose in a Second Life Catholic church

Figure 14 Author's Second Life avatar using 'Jesus Cross with Animation' (created by Trigit Amat) 



\section{Acknowledgments}

This book originated in my $\mathrm{PhD}$ thesis, undertaken at University College London (UCL) (2010-2014). My postgraduate studies would not have been possible without the financial support of the Arts and Humanities Research Council. I am truly indebted to my primary supervisor, Jane Gilbert, and my secondary supervisor, Katherine Ibbett. Simply put, I am a far better scholar than I could ever have imagined thanks to their guidance, dedication to scholarly rigour, and inexhaustible cheerleading. Generous funding from the Modern Humanities Research Association facilitated the revision of my $\mathrm{PhD}$ thesis into the present volume. I thank the Association unreservedly. The Department of French in Queen Mary University of London (QMUL) and the Institute of Advanced Studies (IAS) at UCL have been my home during the revision process. At QMUL, I could not have wished for a more supportive mentor than the inimitable Adrian Armstrong, a partner-in-crime in the best of ways. My mentor at the IAS, Bob Mills, has been a shining beacon of encouragement, and a sage career advisor. Bill Burgwinkle, my former supervisor for undergraduate and Masters-level research in Cambridge, continues to inspire me to push for the most incisive, the most innovative thinking. All of these individuals have provided excellent reminders, whether in their own research or in our conversations, of the pleasures of ground-breaking, solid scholarship. Amsterdam University Press, and especially my crack editor Shannon Cunningham and my copyeditor extraordinaire Tyler Cloherty, have astounded me with their gusto for my work. It is a rare gift to be told to take intellectual risks, to turn the scholarly volume up to eleven. I will forever be grateful for this warm welcome.

Throughout this project, many have generously shared their research and expertise with me. These contributions have indubitably enriched my project, and I am grateful to all those who have donated their time, energy, and knowledge. In particular, I would like to thank: Rebeca Sanmartín Bastida, Jacques Berlioz, Marie Anne Polo de Beaulieu, Elisa Brilli, Rosanna Cantavella, Martinus Cawley, Anna Caterina Dalmasso, Bernhard Drax, Tim Hutchings, Clare Monagle, Sarah Salih, Fiona Tolhurst, Laura Varnam, and Edward Vodoklys. As this project developed, I presented work in progress in a variety of conferences and seminars. Audiences offered both enthusiasm for, and constructive criticism of, my work, enabling me to develop my thinking in terms of this project and more generally as a scholar. Numerous individuals also donated their precious time to my research as participants in, or consultants for, my primary research in the online virtual world of 
Second Life. I am immensely thankful for my interviewees' openness, their excitement about my research, and for the fact they placed their trust in me to share details of deeply personal faith experiences.

As I write these remarks, I notice that I am surrounded by my own network of extraordinary visionary women. I stand perpetually in awe of their bravery, their grit, and their decision to embrace happiness whenever possible. I can't help but think that this book, about a medieval community of awesome women, is inspired in some way by them. This book would not be possible without my mother, Shirley, whose determination to hope and to survive against all the odds, love of all kinds of knowledge, and bone-deep generosity has propelled me ever forwards. To her, and to all those who have offered me unfailing support - my Magpie Sisters, my chosen sisters, and my chosen family - I say thank you. Finally, Jon, the eagle to my shark: I'm so glad that you exist. 


\section{Introduction: Ecstatic Cinema, Cinematic Ecstasy}

At the age of six, I took a vow of silence. I had witnessed something so exquisite, so evanescent that I had to memorialize it. I had to sacrifice my words on the altar of something greater than myself. What engendered this act? The impossible purity of love shared by a singing bibliophile and a bestial curmudgeon. I had just seen Beauty and the Beast (Gary Trousdale and Kirk Wise, 1991) at the cinema. In the dark embrace of a nondescript multiplex on an otherwise forgotten afternoon, I had seen - and felt - the truth of the universe, or so it seemed. It was, for want of a better word, mystical. Sure, the singing teapot didn't hurt my complete and overwrought devotion to the film. And I had to abandon my silence a few hours later, so as to stop annoying my Mum. But still. For those brief few hours, I ascended the lofty heights of knowledge of how to be human, how to be in the world, and perhaps most importantly how, eventually, I would be an adult. I was in the film; the film was in me.

The principal contentions formulated in this book lie in the crux of that experience, and are threaded through the analyses in the pages that follow. I maintain that medieval mystical episodes are made intelligible to modern audiences through reference to the filmic - the language, form, and lived experience of cinema. Similarly, reference to the realm of the mystical affords a means to express the disconcerting physical and emotional effects of watching cinema. Moreover, cinematic spectatorship affords, at times, a (more or less) secular experience of visionary transcendence: an 'agape-ic encounter'. This transcendent experience is functionally identical to the episodes of ecstasy which are the mainstay of medieval hagiography. This is not to say that all moviegoers are, actually, Catholic mystics, if only they knew it. Rather, I attest that our use, enjoyment, and conceptualization of cinema - and more recently, three-dimensional virtual environments online - reflect our enduring preoccupation with those topics which were previously the domain of religion, and thus hagiography. ${ }^{1}$ This includes: our fear and anxiety of mortality; our quest to understand the intersection of body and soul (with the latter reconstituted now as the dissatisfyingly secularized 'mind'); the need to know what 'lies beyond' our present reality, and 
even peer into others' lives; the desire for a 'user's manual' to the universe, an explanation for why things happen to us.

The cinema functions as an arena for these deeply human topics to be brought to light, discussed, and potentially resolved, at least until the film's credits roll and we are delivered back into the messy reality of our lives. The apparent a-religiosity of the cinema - a technological invention that mystics surely did not have! - serves to neutralize the existential bite of these investigations. It also obfuscates the umbilical connection between medieval and modern subjects. In the past as in the present moment, we scan our respective visual horizons in the hope of ontological answers. As Nicholas Watson remarks, the past 'remains inseparably entangled with the present and will continue to be so however much this fact is forgotten or its relevance denied. [...] Only the mode of that continued existence is in question." ${ }^{2}$ This book stakes the claim that mysticism, or at least a desire for mysticism and the kind of reassurance mystical insight may bring, continues to exist in and as cinema.

Hagiographical scholarship has long struggled with the issue of mediation inherent to the genre. We can never view the hagiographical subject 'face to face'. We set eyes only on the figuration of the holy person provided by the biographer, compelled to author the work by a variety of ideological aims. ${ }^{3}$ In short: the existence of a medieval vita typically 'only proves that a single, literate man [...] was impressed by the woman he described'. ${ }^{4}$ suggest a change of methodological focus. Instead of grappling with the 'problem' of mediation, I propose that we embrace the full weight of the proposition's heuristic possibility: consideration of hagiography as media. In particular, I consider hagiography as cinematic media, in light of the relationship between cinema and mysticism outlined above. Each of the chapters in this book pivot on this understanding of hagiography, and investigate hagiography in terms of different kinds of cinematic media: photography, film, celebrity (as embodied image), and three-dimensional digital environments online.

In the categorization of hagiography as media, I draw on Birgit Meyer's definition of 'media': 'those artifacts and cultural forms that make possible communication, bridging temporal and spatial distance between people as well as between them and the realm of the divine or spiritual'. ${ }^{5}$ In this 
light, it becomes clear that media are, and always have been, 'intrinsic to religion' as a means of making divinity visible, tangible, and intelligible to believers. ${ }^{6}$ The medieval hagiographic media under study in this book, then, are examples of a temporally pervasive, and ongoing, phenomenon. My formulation of hagiography as media relies also on W.J.T. Mitchell's theories of media, with particular emphasis on two key tenets. ${ }^{7}$ Firstly: media are 'environments where images live, or personas and avatars that address us and can be addressed in turn. ${ }^{8}$ Hagiographic media are immersive and communicative. They solicit interactions with readers, and open up spaces of virtuality in which their hagiographic personas live and into which the reader can project themselves. ${ }^{9}$

Secondly, I concur with Mitchell's prouncement that 'media purity' is a fallacy. ${ }^{10}$ All media are multimedia in the sense that they are fabricated from an assemblage of mixed media. A film, for example, is an admixture of image, text, sound, and so on. Consequently, engagement with media is always a multisensuous and multimodal process. Even in the most superficially two-dimensional interaction between reader and book, for instance, we find the visual (the words on the page), the haptic (turning the page), the imaginative and intellectual (processing the words' meaning), and even the olfactory (the smell of the book). Vitae are fundamentally synaesthetic and interactive. Hagiographic media fuse the textual, visual, and the haptic both in the diegesis and in their receptive modes.

The paragraphs above set out the assumptions and contentions which fundamentally inform this book. In the sections below, I add finer detail to this methodological sketch. Firstly, I examine the interconnection of cinema and mystical visionary experience, in terms of the 'agape-ic encounter' and the tendency to speak of cinematic experience in terms of the mystical and vice versa. I introduce the corpus of primary sources for the present study,

6 Ibid., p. 127. On this, see also: 'Medium', in which the citation appears verbatim on p. 60.

7 Lives and Loves, pp. 201-21.

8 Ibid., p. 203.

9 This associates hagiography with other medieval media which aim at engendering authentic yet virtual experiences. This includes, for example, guided meditational manuals in the tradition of affective piety which place the reader-cum-seer in the thick of biblical history, such as Aelred of Rievaulx's De institutione inclusarum and the Meditaciones vite Christi (dubiously ascribed to John of Caulibus). I refer to the latter briefly in Chapter 4, pp. 193-94. Virtuality was equally central in medieval pilgrimage guides to, and images of, Jerusalem for the imaginative use of those for whom travel to the holy site in person was impossible. For details and analyses of such works, see: Rudy, 'Cityscape'; ‘Guide'; 'Fragments'; Virtual Pilgrimages.

10 Lives and Loves, p. 215. Mitchell writes extensively on this topic, see in particular: Iconology, pp.7-46; Image Science, pp. 13-21; 125-35. 
and my rationale in selecting the medieval and modern works. Following a discussion of the potential limiting factors of the present study, I provide a summary of each chapter.

\section{The Agape-ic Encounter}

Writing in 1975, Margaret A. Farley developed a radically egalitarian feminist ethics of Christian agape (perfect, transcendent or divine love; charity). The role of women in the practice of agape had long been determined according to the sexist logic of theology, in which women were 'by nature' inferior to men. ${ }^{11}$ Agape for women, then, obliged self-sacrifice and self-effacement. Men reaped the rewards of these loving martyrdoms, whilst also asserting themselves in the practice of agape, as befitting their status as the active sex. In the prevailing theology of the early twentieth century, agape was dependent on, and indeed expressed as, 'other regard'. ${ }^{12}$ This amounts to an all-encompassing appreciation of and dedication to the other, brought out by the relinquishing of all 'self regard' (or 'self love'). Farley challenged this definition of Christian love, arguing for a recognition of agape instead as 'active receptivity and receptive activity', founded on open-ended mutuality between persons. ${ }^{13}$

The basis of Farley's agape is the 'equal regard' between all humans, and between humanity and divinity. ${ }^{14}$ If radically and fully applied, this 'equal regard' enacts agape as: 'the meeting between lover and beloved (whether God or a human person) which is utterly receptive but utterly active, a communion in which the beloved is received and affirmed, in which receiving and giving are but two sides of one reality which is othercentred love. ${ }^{15}$ My intense experience with(in) Beauty and the Beast was an 'agape-ic encounter' of this kind. My insistent gaze towards the screen, my beloved, was reciprocated by a look emanating from the screen, from the film itself. In the confluence of these two 'equal regards', I emptied myself out actively as much as I was filled up passively by the movie onscreen. It

11 Farley, pp. 634-40.

12 On this background, see: Andolsen, pp. 146-50.

13 Farley, p. 638.

14 Ibid., p. 633. Farley leverages Gene Outka's work in which agape is defined as 'equal regard', though without attention to the feminist potentiality of this: Outka, pp. 7-54, 260-91. Agape as 'equal regard' has come to be accepted as one of the most dominant interpretations of the concept. On this, see: Pope.

15 Farley, p. 639. 
was transcendent, a flickering existence both beyond myself and entirely of myself. The 'act of looking' became 'a way of relating', structuring the relation to myself and to the world. ${ }^{16}$

By literalizing the 'equal regard' of Farleyian agape, I stake the claim that the scopic act can be an experience of complete mutuality between the individual who looks and that which is looked at. Moreover, I contend that this spectatorial mutuality is rendered most fully intelligible in two domains: cinematic visions in the modern movie theatre, and divine visions as detailed in medieval hagiographical texts. In each, the reciprocal literalized sightlines at play (moviegoer to/from screen; saint to/from God) produce an 'agape-ic encounter'. The lived experience of this exchange of 'equal regards' is characterized by a sense of transcendence, both for the modern cinema-goer and the medieval visionary saint. The sense of transcendence - an intellectualized apprehension of what is happening in the scopic instant - is conjoined with the sensation of transcendence. For the evanescent glory of the 'agape-ic encounter' is also, paradoxically, felt intensely in the viewer's body. This is due to the inherently synaesthetic nature of the scopic act, in which looking opens out into multisensory experience across the viewer's entire body. The agape-ic spectatorial experience is functionally identical in ecstatic episodes of divine visions that are the mainstay of medieval hagiography and in the transcendent episodes felt and lived in the cinema.

The framework of the 'agape-ic encounter' offers a counterpoint, and means to move beyond, earlier theories of film spectatorship which pivoted on the notion of film spectatorship as ineluctably objectifying, particularly to women. The most famous of such theories is found in the work of Laura Mulvey, with an insistence on the 'male gaze' of the camera and an attestation of the female spectator as perpetually passive. ${ }^{17}$ The 'agape-ic encounter' foregrounds that scopic mutuality is possible, and can be experienced. ${ }^{18}$ However, this is not the default viewing position for either the modern cinema-goer or the medieval saint. Whilst they might feel like an eternity or mere seconds, ecstasies (cinematic and otherwise) are transitory states, extra-ordinary in their nature as beyond the ordinary spectatorial regimes that enfold us, yet dependent on those regimes for their socio-cultural signification(s).

17 Mulvey, 'Pleasure', 'Afterthoughts'; Mulvey and Sassatelli, 'Interview'. For a useful summary of critical responses to the Mulveyian 'male gaze', see: Chaudhuri, pp. 31-44.

18 Vollmer, pp. 50-52. 
The 'agape-ic encounter' is produced by and in the act of genuinely reciprocal spectatorship: by looking at an object which exerts itself simultaneously as a subject, that returns a look that makes plain one's own object-hood. In the cinema, I meet the film's gaze; in hagiography, a holy woman meets God's gaze. So doing, we perceive (feel and see) ourselves being seen, and thus we are looked and felt into being. Functionally speaking, film is divinity in the re-staging of the mystical vision into the cinema theatre. Nevertheless, I favour the term 'agape-ic encounter' as a means of undercutting any simplistic one-to-one identification of this experience as a definitive encounter with or of agape. The signification of this momentary transcendence, engendered by the visual act, is bound up with the macro socio-cultural frameworks to which the viewer is subject, and their own individual beliefs and ethics. Yet, the notion of the 'agape-ic encounter' cuts to the heart of what is so unsettling about experiences in which we seem, however briefly, to find communion in the cinema theatre. They feel religious-ish, or mystical-ish. Not completely religious, certainly, but not not of that ilk either.

\section{Ecstatic Cinema}

I am not alone with my 'agape-ic encounter' in the cinema. Such encounters correspond to episodes of cinematic vision(s) that evince, as Vivian Carol Sobchack puts it, 'transcendence in immanence' ${ }^{19}$ That is: the intensely felt apprehension of the mutual imbrication of mind and body, the ontological and the ontic, brought about by cinema spectatorship. Sat in the cinema theatre, we are tethered, as ever, to the material fact of our bodies. Yet this radical materiality carries within itself the capacity to transcend its physical borders. As an anchor to a "'here"' and '"now"', the body also points towards an "elsewhere"' and "'otherwise"'. In the movie theatre, the body literally points towards that "elsewhere"' and 'otherwise"': directly facing the screen into which we immerse ourselves. We experience transcendence in the movement of our gaze - a metonymy for our entire being - towards the screen. This movement 'relocates us "beyond" the presentness of our flesh to dwell in the on-screen world'. For Sobchack, this movement is properly termed an 'ek-stasis', drawing on the Greek definition of the word as literally to be "put out of place". ${ }^{20}$ Dynamically propelled away from ourselves and

19 Emphases in original. 'Embodying Transcendence', p. 197.

20 Emphases in original. Sobchack uses the term in 'Embodying Transcendence' (pp. 197-98, p. 202) and in Carnal Thoughts (pp. 297-98, p. 301). She glosses it in the latter, p. 297, n. 24. 
our lived reality, we accede to 'a unique extoriority of being'. ${ }^{21}$ However, this 'ek-stasis' is also a movement inwards, as we inhabit 'our own fleshly presence' with an intensity equal to the velocity of our ' $e k$-static' trajectory outwards. ${ }^{22}$ What results is 'a porous experience that transcends not only any single sense perception but also traditional subject-object, here-there, inside-outside dichotomies. ${ }^{23}$

According to Sobchack, episodes of 'transcendence in immanence' fill the cinema spectator with 'grace' and a sense of 'the sublime'. ${ }^{24}$ These reactions do not depend on the spectator's faith, or indeed the subject matter of the viewed film. For Sobchack, an avowed atheist, they are instead instances of a transcendence divested from religion, located in the movie theatre and produced by the act of cinematic spectatorship itself. ${ }^{25}$ This is a secular form of transcendence, ontologically inflected 'in [the] egological recognition that we are some "thing" more (and less) than egological beings' ${ }^{26}$ Sobchack's insistence on the secularity of the experience is telling, and not entirely persuasive. It is emblematic of the pervasive sense of unease generated by experiences which should be secular but feel like something else, something 'more'. Indeed, Sobchack explicitly connects the movie theatre and the church as two spaces in which 'ek-static transcendence is not only purposefully solicited but also formally shaped and experientially heightened'. Apart from the differing significations accorded to the spectatorial experience itself after the fact - we either saw God (church) or saw the very extent of ourselves (cinema) - what is there really to differentiate the two modalities of spectatorship? They are both, ultimately, 'agape-ic encounters'.

Sobchack posits that the spectator's movement towards the screen involves their removal 'imaginatively, intellectually, or spiritually' from their bodily instant. ${ }^{27}$ This fabricates an unnecessarily rigid distinction between the three modes of relation with the screen. In fact, an initial imaginative or intellectual engagement with the screen opens up a space for a spiritual liaison with the film in the act of spectatorship itself. I use the term 'spiritual' here in explicit counterpoint to the term 'religious'. themes in Sobchack's theories, see Cooper, pp. 108-17.

26 Carnal Thoughts, p. 298.

27 
Whilst the latter connotes organized institutional religion, the former hinges upon a considerably more diffuse awareness of the sacred stuff of life, encountered primarily in individualistic encounters to which the spiritual individual assigns their own meaning. This distinction is captured well in the ever more common identification of being 'spiritual, but not religious'. ${ }^{28}$ A spiritual attitude is secular, 'but in a very special, soul-filled way'. ${ }^{29}$

Nevertheless, a spiritual-cinematic encounter may be overlaid with a religious meaning by a devout believer and thus the experience may become religious. The point is not that the state of filmic 'transcendence in immanence' (or the 'agape-ic encounter') is unequivocally spiritual (or indeed religious), though it may be for some cinema spectators. Rather, its character cannot be adequately expressed in an entirely secular framework: it forces a return to the lexical domain of mystical religiosity as a way of making sense of the experience. Hence, Sobchack turns to 'ek-stasis' to express the fundamental character of the cinematic visions she analyses, and she herself has experienced. The retention of the (transliterated) Greek orthography and hyphenation in the term 'ek-stasis' operates as a distancing mechanism from the mystical and religious baggage of the term 'ecstasy'.

\section{Cinematic Ecstasy}

In a post-Englightenment context, the spectre of Sobchack's ecstastic cinema is a deeply troubling destabilization of rationality's claims. What's more, such experiences operate as an emphatic and empiricist avowal of the interconnection of mind and body. The dictum 'mind over matter' falls by the wayside: mind is matter, and thus matter matters very much. The situation is not necessarily much better for staunch Christian believers. The ecstatic capacity embedded in cinematic spectatorship threatens the mystical monopoly in which the Church has trafficked for centuries..$^{30}$ The experience of 'transcendence in immanence' shortcuts the established route to a communicative encounter with divinity which depends upon obedience to doctrine and submission to clerical hierarchies. Equally, it suggests divinity is as much 'out there', outside the Church (and the church), as it is contained and preserved within the fibre of its being. If you can see

28 Kripal, 'Secrets', p. 300-01. On this, see also: Drescher, Religion, in particular pp. 53-88; Mercadante; Parsons; Strieber and Kripal, pp. 54-56.

29 Strieber and Kripal, p. 55.

30 On this, see in particular: Kripal, 'Secrets', p. 296. 
God in the movies, who needs to go to church? As a self-defence mechanism, the religious establishment must deny at all costs the mystical potential (or resonance) of the cinema. Or, at the very least, negotiate on the form and extent of that extra-ecclesiastical ecstatic experience, try to broker a good deal on the resulting spiritual sentiments and access to divinity. This is a central conundrum for the medieval Church when dealing with visionary holy women, and an issue which I explore from various angles in the rest of this book.

Much as some might find it surprising, our contemporary moment is not devoid of mysticism understood as such, with or without the stamp of approval from religious authorities. Whitley Strieber and Jeffrey J. Kripal, for example, present numerous contemporary paramystical visions which bear the hallmarks of the 'agape-ic encounter' sketched above, a mutuality enacted by a reciprocal gaze which radically implicates the body. Strieber, for instance, recounts a paranormal vision he received in 2014, featuring an entity appearing initially as seven glowing balls:

When I asked to see him as he really was, he appeared as a little star hanging over the front yard. It was radiant, and the rays were like living light. They penetrated my skin, bringing with them the most intimate sense of human touch I have ever known. It was a moment of transcendent beauty and joy. ${ }^{31}$

Another modern visionary, Paul Marshall, receives a vision of small, moving circular life-forms that 'were simultaneously both in him [...] and yet also exactly the same as he was, all-knowing and all-inclusive, the recognition of which triggered universal love. ${ }^{32}$ Strieber and Kripal characterize such paranormal visions as modern eruptions of mysticism, which in other times and locations may be understood as divine visions in the Christian context. ${ }^{33}$

Mysticism renders the invisible visible, but the nature of that visible entity shifts according to social mores. Whatever form the vision takes, all mystical and paranormal episodes are moments in which a visionary communicates with, according to Strieber and Kripal, a 'soul-of-the-world' or 'cosmic mind'. ${ }^{34}$ This entity, envisioned as a kind of mind separate from 
biology or free-floating consciousness, is not separate from us: it is 'us and not us at the same time' ${ }^{35}$ When perceived by humans, this 'deeper consciousness [...] beyond the ego' appears in the form of the 'Other or Alien', the divine or the paranormal..$^{6}$ Staring this 'Other' in the eye, we see 'both our own humanity and our own divinity'. ${ }^{77}$ This is an 'agape-ic encounter', a parallel to Sobchack's realization as to the enmeshment of the ontological and the ontic. However, such an encounter is transcendent, according to Strieber and Kripal, only if the viewing subject is capable of ceding their egological sovereignty. ${ }^{38}$ If the ego can 'let go of itself', then it may merge with the fabric of the world itself: a communion leading to ecstasy following the logic of Sobchack's cinematic 'ek-stasis'.

Strieber and Kripal repeatedly turn to metaphors of cinematic spectatorship to elucidate their hypotheses. Visionary encounters with the cosmic consciousness are like watching movies with one's 'own private movie screen' ${ }^{39}$ By watching this movie screen, individuals can - paradoxically - "wake up" out of the social and sensory movie that they are caught in as characters. They peel themselves as perceptions off the screen, turn around, and come to know something of the projecting light streaming in from behind or above them.' ${ }^{40}$ This luminescence is the 'cosmic mind' itself, which operates 'much like the lights dancing on the movie screen', capable of taking on 'any cultural narrative (or myth), any subjective form (or ego)'. ${ }^{41}$ In the context of prophetic visions, the human mind works 'like a camera and a video projector.' ${ }^{42}$ The multifunctional apparatus 'sees" and then projects what is happening at some distance along the space-time continuum within a mini-movie in the mind of the visionary.' Sobchack's cinema is ecstatic; Strieber and Kripal's ecstasies are cinematic.

Strieber and Kripal's recourse to the filmic to explain contemporary mystical phenomena is mirrored in a noteworthy amount of medievalist scholarship in which hagiography is situated in terms of cinema. Catherine Innes-Parker, for example, suggests that the typical narrative of the female martyr is 'like a script for the worst kind of pornographic film'. ${ }^{43}$ Discussing 
the potent orality of Margery Kempe's Book, Barbara Newman suggests that if more medievalists were filmmakers, the book would 'yield an excellent screenplay'. ${ }^{44}$ Bernard McGinn proclaims that vitae 'may perhaps be seen as something like modern film'. ${ }^{45}$ Such comments are frustratingly vague. This book seeks to rectify this limitation, fleshing out more fully the interplay of the medieval hagiographic with the modern cinematic. Nevertheless, McGinn offers the most fulsome explanation of the cinematic nature of hagiography, which I detail in a section below.

\section{The 'Holy Women of Liège'}

McGinn's critique is fruitful also in terms of formulating a corpus of medieval material for study of the cinematic quality of hagiography. The volume in which McGinn sets forth his hypothesis specifically examines the 'new mysticism' that emerged in the period 1200-1350. He characterizes the religiosity of this pan-European movement as 'visionary, ecstatic, excessive'. ${ }^{46}$ Some of the earliest traces of the lifestyle, or one specific form of it, are found in the textual corpus of the 'Holy Women of Liège'. With few exceptions, this corpus provides the medieval material for this book. The corpus comprises a collection of Latin prose biographies, either with an avowed male author or from an unknown hand. This book examines twelve vitae in particular: Alice of Schaerbeek (the Leper) (c. 1220-1250), Beatrice of Nazareth (1200-1268), Christina Mirabilis (the Astonishing) (1150-1224), Elisabeth of Spalbeek (c. 1246-after 1248), Ida of Léau (c. 1200-1266), Ida of Louvain (c.1212-c. 1261), Ida of Nivelles (1199-1231), Juliana of Mont-Cornillon (c.1192-1258), Lutgard of Aywières (1182-1246), Margaret of Ypres (1216-1237), Marie of Oignies (c. 1177-1213), and Yvette of Huy (1158-1228). See Table 1 for a summary of the holy women's vital statistics. ${ }^{47}$

The Liégeoise vitae are apposite objects of enquiry in the present study for several intersecting reasons. Firstly, the texts are replete with ecstatic visionary experiences. Such episodes reveal the form, content, and function of divine visions in the period. Again and again, the visions reveal the problematic division of body and soul, Christ and human. They also emphasize

44 'Clash', p. 29.

45 P. 20.

46 Ibid., p. 30.

47 Data in Table 1 are adapted from those provided in primary sources, and in: Carpenter, 'New Heaven', pp. 5-6; Delle Stelle, pp. 432-518; Simons, 'Survey', pp. 647-62. 


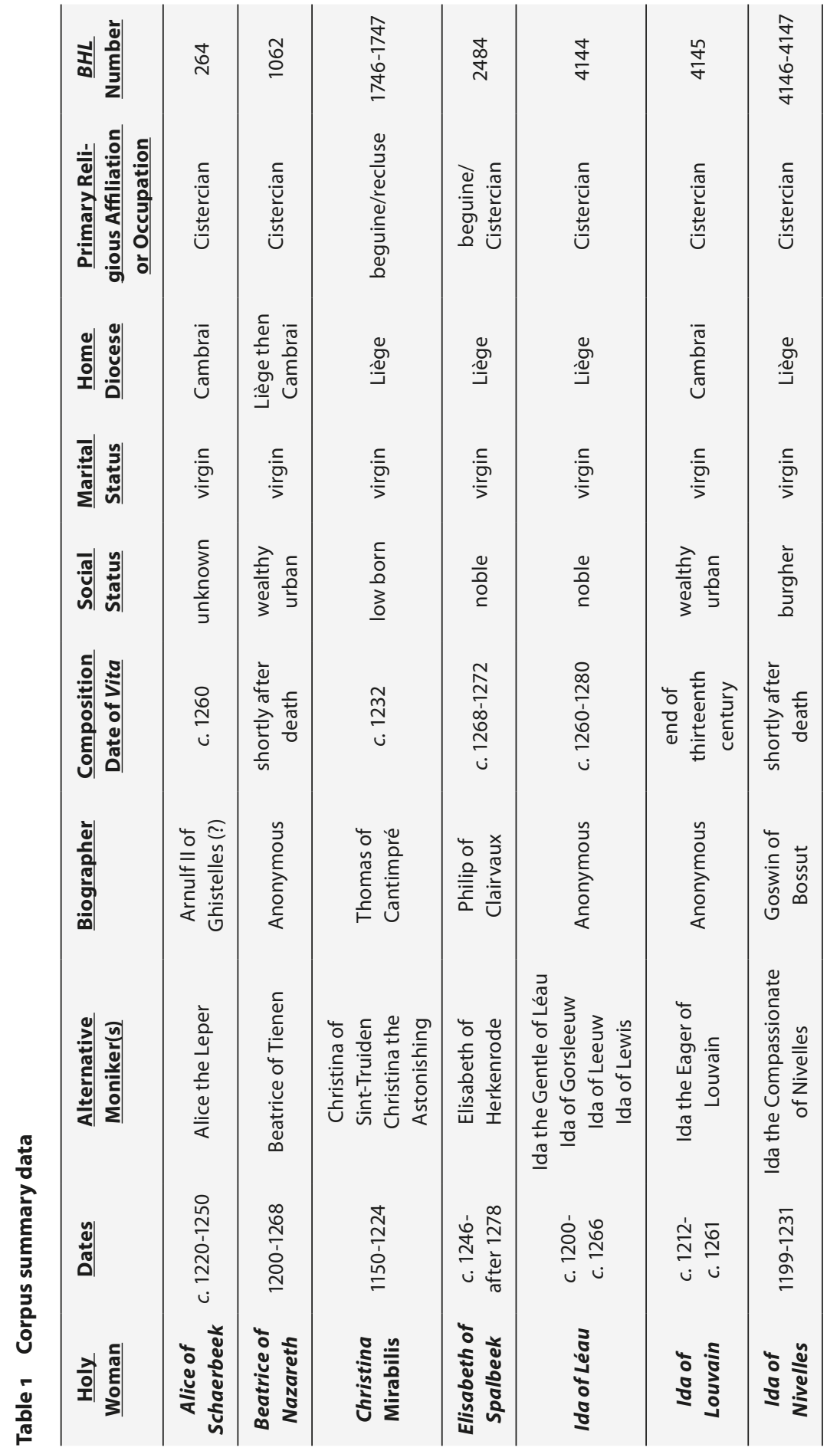


INTRODUCTION: ECSTATIC CINEMA, CINEMATIC ECSTASY

\begin{tabular}{|c|c|c|c|c|c|}
\hline 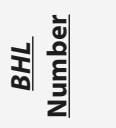 & $\overline{\mathfrak{N}}$ & 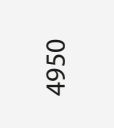 & $\frac{a}{n}$ & 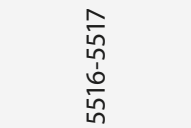 & ণ্ণু \\
\hline 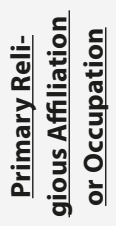 & 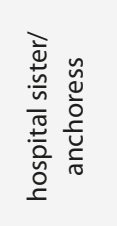 & 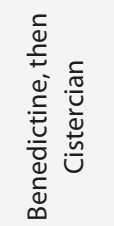 & 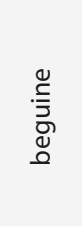 & 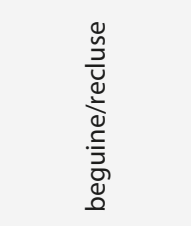 & 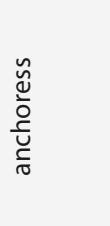 \\
\hline 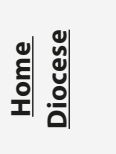 & :ֶّ & $\begin{array}{l}\mathscr{D} \\
: \underline{\Xi}\end{array}$ & 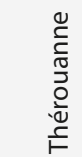 & : & : \\
\hline 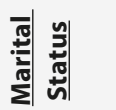 & :气 & $\begin{array}{l}\stackrel{5}{5} \\
\stackrel{5}{>}\end{array}$ & $\stackrel{5}{\frac{5}{>}}$ & 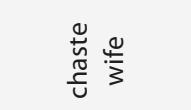 & 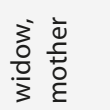 \\
\hline 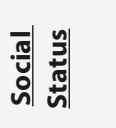 & $\frac{0}{0}$ & 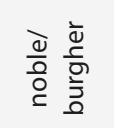 & 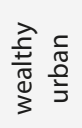 & 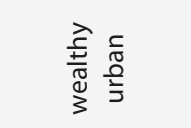 & 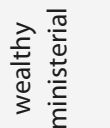 \\
\hline 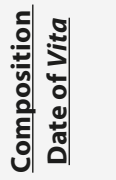 & 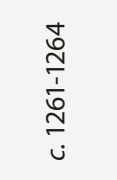 & 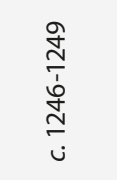 & $\underset{i}{\stackrel{O}{I}}$ & 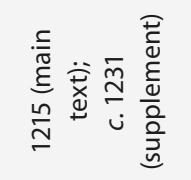 & 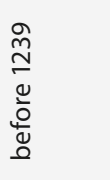 \\
\hline 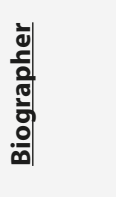 & 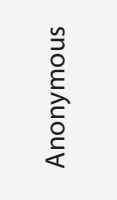 & 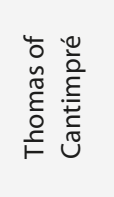 & 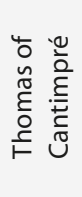 & 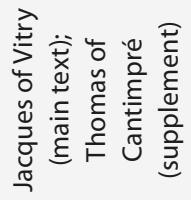 & 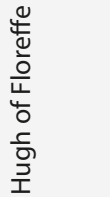 \\
\hline 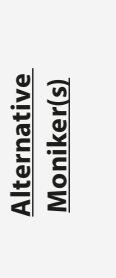 & 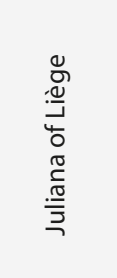 & 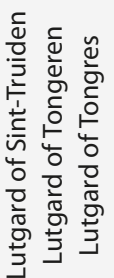 & ' & 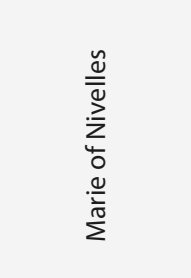 & 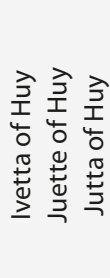 \\
\hline $\begin{array}{l}\tilde{y} \\
\stackrel{y}{\pi}\end{array}$ & 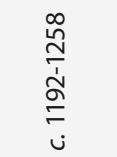 & 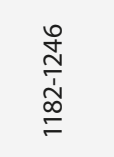 & 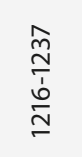 & 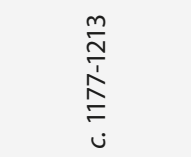 & 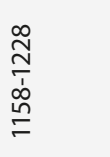 \\
\hline 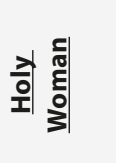 & 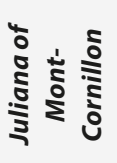 & 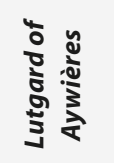 & 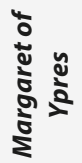 & 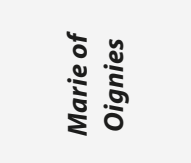 & 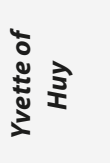 \\
\hline
\end{tabular}


that the viewer's body is central to the scopic act itself, as the visionary experiences intensely physical mystical unions with Christ. Secondly, this content demonstrates the ways in which text can transmit experiences of the visual, the haptic, and the virtual to the reader. In this, then, they are excellent examples by which to elucidate a theory of hagiography as media. Finally, as visionaries in the mould of the 'new mysticism' of the thirteenth century, the holy women of Liège throw into stark relief the shifting power dynamics between laity and clergy. Their holiness, founded upon their mystical visionary capacity, permit their involvement in social, political, and religious spheres. Yet, they can never exist wholly independent of the clergy. The Liégeoises are neither fully of the profane nor the sacred world. In this, they share the character of the modern cinematic experience as neither outright mystical (sacred), nor completely rationalize-able (profane).

In his prologue to Marie of Oignies' (d. 1213) vita, Jacques of Vitry (d. 1240) summarizes the key features of the new lifestyle evident in the diocese of Liège in the early thirteenth century:

They had scorned carnal enticements for Christ, despised the riches of this world for the love of the heavenly kingdom, clung to their heavenly Bridegroom in poverty and humility, and earned a sparse meal with their hands, although their families abounded in great riches. Forgetful of their people and the home of their father, they preferred to endure distress and poverty than to abound in riches that had been wrongly acquired or to remain in danger among worldly pomps. You saw holy women serving God and you rejoiced. With what zeal did they preserve their youthful chastity, arming themselves in their honourable resolve by salutary warnings, so that their only desire was the heavenly Bridegroom. [...] Frequently they recalled to memory the words of the Apostle that the widow 'that lives in pleasure is dead' [I Timothy 5.6] and, because holy widows 'share with any of the saints who are in need', they washed the feet of the poor, 'made hospitality their special care' [Romans 12.13], applied themselves to works of mercy, and promised to bear fruit sixty-fold [cf. Matthew 13. 18].48

48 VMOEng, prol. 3.42-43. '[...], quae spretis pro Christo carnalibus illecebris, contemptis etiam amore regni caelestis hujus mundi divitiis, in paupertate \& humilitate Sponso caelesti adhaerentes, labore manuum tenuem victum quarebant, licet parentes earum multis divitiis abundarent. Ipsae tamen obliviscentes populum suum \& domum patris sui, malebant angustias \& paupertatem sustinere, quam male acquisitis divitiis abundare, vel inter pomposos seculares cum periculo remanere. Vidisti (\& gavisus es) sanctas \& Deo servientes matronas, quanto zelo juvencularam pudicitiam conservarent, \& eas in honesto proposito, ut solum caelestem Sponsum 
These medieval Liégeoises develop their piety outside of enclosure, and thus are known commonly but not necessarily accurately as 'beguines'. The women embrace work in society, such as tending the sick and the poor and even work in textile production, whilst simultaneously devoting themselves to God. Equally, they undertake a life of holy poverty. As shown in Jacques' description, chastity, poverty, humiliating and merciful service to the poor and the sick, with a constant remembrance of the Lord's munificence, are essential elements of the beguine way of life. Such a lifestyle exemplifies the vita mixta, the combination of active and contemplative religious practice.

Visionary experience is also essential to the Liégeoise lifestyle: all the holy women have divine visions. This outbreak of visionary acuity is not due to some biological cause, a genetic mutation or mystical spider bite. Rather, the women's mystical capacity is constituted, legislated, and shaped by the precise socio-cultural context(s) in which they are situated. As such, the divine visions are both a product of and response to the forces which governed life as a woman in thirteenth-century Brabant-Liège. The chapters in this book consider in depth 'how' and 'what' the holy women see. Such analyses are grounded in an acknowledgment of the ways in which the 'when' and 'where' directly impact the 'why', the rationale and very possibility of the Liégeoise's mystical visions. This is the work to which I devote the rest of this section. Put otherwise: before turning our attention fully to the cinema screen in later chapters, we must now briefly switch our attention to the projectionist, the hidden hand which makes the film appear before our eyes. This switch permits a deeper understanding of the socio-cultural ground in which the Liégeoise's visions are anchored. It also enables us to consider the impact of our own role as scholarly projectionists, i.e. the ways in which modern scholars project upon the holy women certain subject positions, primarily with the problematic label of 'beguine'.

The beguine movement was formed at the turn of the thirteenth century in the Low Countries, shaped by the dense urban environment of its major cities such as Bruges, Ghent, Antwerp, Brussels, and Liège (see Figs. 1-4 for maps). The area saw impressive economic development and had an established literary culture, operating in both Dutch and French vernaculars.

desiderarent, salutaribus monitis instruerent. [...] frequenter ad memoriam revocantes illud Apostoli: Vidua, quae in deliciis vivit, mortua est: \& quod sanctae viduae, quae Sanctorum necessitatibus communicant, quae pedes pauperum lavant, quae hospitalitatem fectantur, quae operibus misericordiae insistunt, fructum sexagesimum promerentur.' VMO, prol. 3.636-37. The 'you' to whom Jacques directs these remarks is Fulk, bishop of Toulouse. For more references to the significant number of pious female religious in Liège, see: VILéau, 1.4.109; VIH, 44.113.884; VIN, 22.253-56; VMO, 2.6.57.651; 2.11.101.663. 
Figure 1 Map of the Low Countries, c. 1100-c. 1500

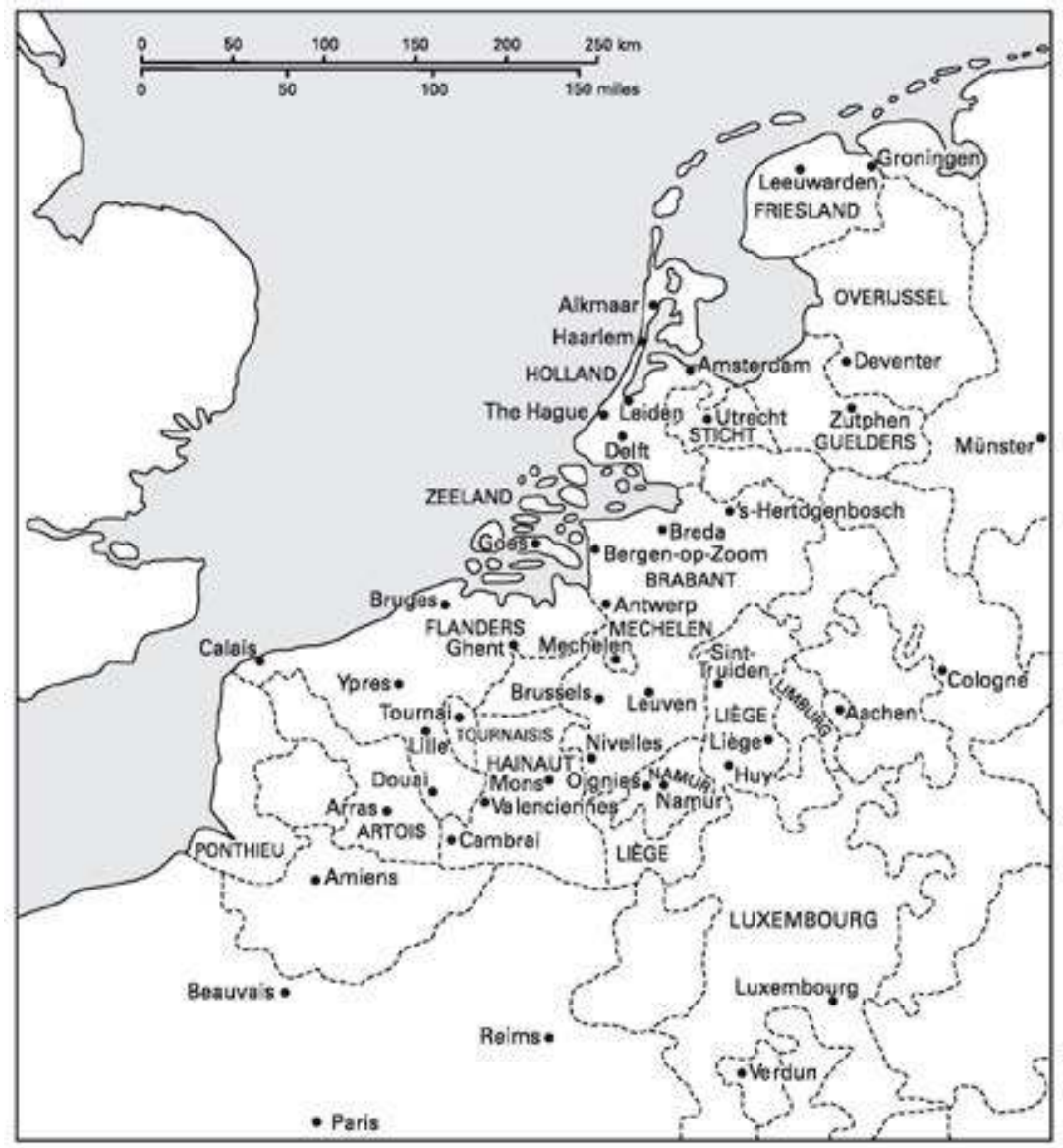

Reproduced with permission of Cambridge University Press, from Miri Rubin and Walter Simons, eds., Christianity in Western Europe c. 1100-c. 1500 (Cambridge: Cambridge University Press, 2009), p. $x x i$

Urban development provoked the disintegration of rigid social barriers and the emergence of a new middle class. The borders between spiritual and secular became more porous than ever. Preachers roamed the urban centres, spreading religious devotion, whilst work guilds embraced patron saints, and the lay public became informed about purgatory and the fate of the soul after death via popular spiritual tracts.

Alongside such increased interaction between the religious and profane worlds, women were facing specific changes and challenges to their conventional social roles, which provoked the development of new forms of 
Figure 2 Map of the southern Low Countries in the thirteenth century, showing principal towns and regions

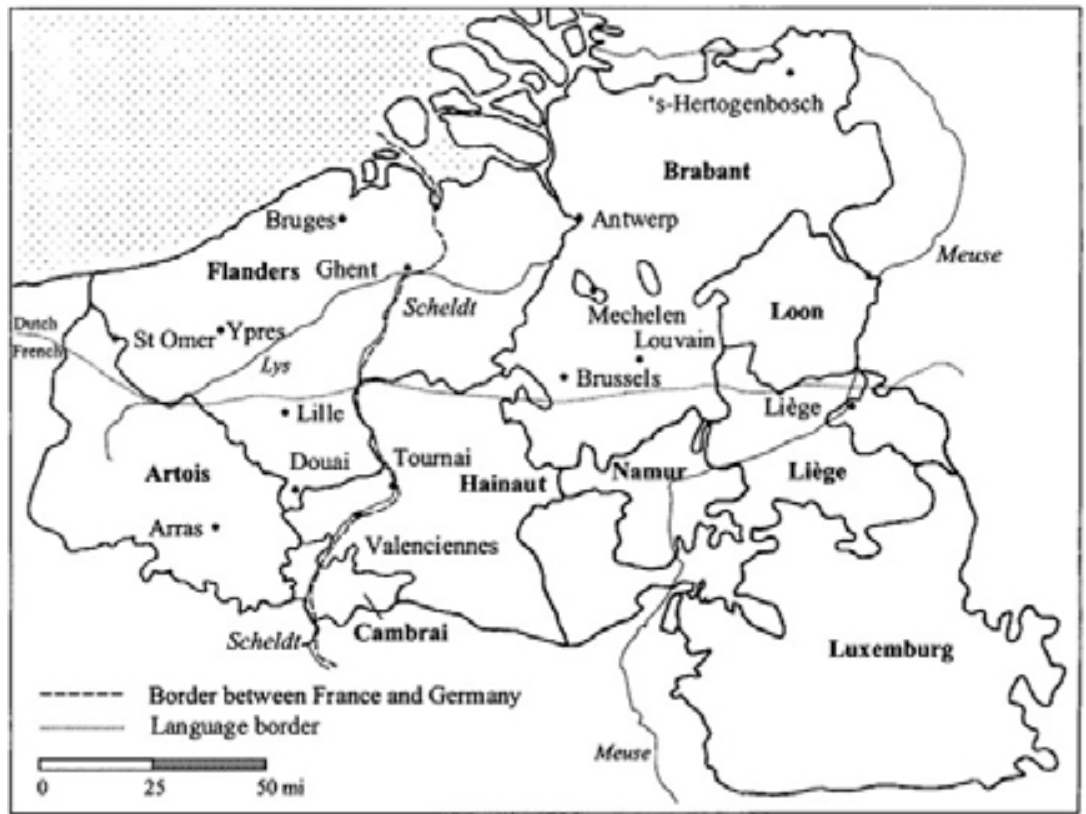

Reprinted with permission of the University of Pennsylvania Press, from Walter Simons, Cities of Ladies: Beguine Communities in the Medieval Low Countries, 1200-1565 (Philadelphia: University of Pennsylvania Press, 2001), p. 2

religion. The so-called Frauenfrage - the surplus of unmarried women due to a variety of factors inhibiting the ability or proclivity of men to marry precipitated a significant demand for space in nunneries, leading to higher prices for entry. A notable portion of the growing ranks of the middle classes could not afford to send their daughters to monastic institutions which demanded large dowries, and the foundations themselves simply could not house all those wishing to enter their walls. Certain orders would not accept new female religious, such as the Premonstratensians from $1170 .{ }^{49}$ The Premonstratensians were the beguines' 'precursors', as the Order's founder Norbert of Xanten (d.1134) permitted female religious to actively engage in the world by doing acts of charity. ${ }^{50}$ Foreclosure of the Premonstratensian option, then, severely curtailed women's choices for an active religious lifestyle. Beguinages, the communities which typically housed a group 
Figure 3 Dioceses in the southern Low Countries, 1146-1559

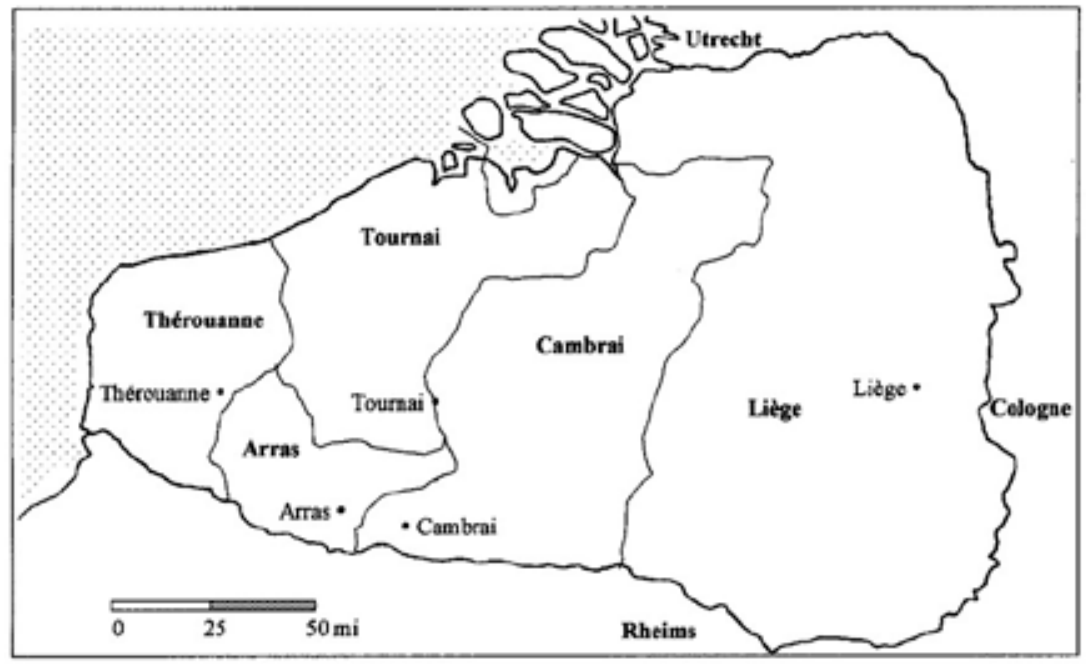

Reprinted with permission of the University of Pennsylvania Press, from Walter Simons, Cities of Ladies: Beguine Communities in the Medieval Low Countries, 1200-1565 (Philadelphia: University of Pennsylvania Press, 2001), p. 13

of beguines, also increased in number over the thirteenth century..$^{51}$ By $135^{\circ}$, it is estimated that there were perhaps as many as three hundred beguine communities in the Low Countries, two thirds of these in what is now Belgium. ${ }^{5^{2}}$ Although afforded limited freedom from clerical control as they remained in the world, the women availed themselves of the spiritual services of the clergy, such as the performance of Eucharistic rites. However, they were not affiliated with a specific monastic order.

Beguines and beguinages gained legitimacy in the eyes of the Church by dint of significant support from a group of powerful religious men such as Jacques of Vitry (Augustinian canon regular at the church of Saint-Nicholasof-Oignies in Liège 1210-1216; bishop of Acre 1216-1226; cardinal-bishop of Frascati (also known as Tusculum) from 1229; d. 1240), John of Nivelles (canon of collegiate church of Saint-John at Liège; joined Augustinian priory of Oignies before 1219; d. 1233), John of Liroux (probably a canon at

$5^{1}$ Simons, 'Margins', p. 320.

$5^{2}$ Simons, 'Survey', p. 627. For a summary of the development of the beguine lifestyle from isolated women to institutional living, see: McDonnell, Beguines, pp. 4-7. For a study of the beguinages in Oignies, Nivelles, and Namur, see: ibid., pp. 59-70. For a study of the Parisian beguinage, see: Miller, Gender. For a quantitative overview of beguine communities 1200-1565 in the Low Countries, see: Simons, Cities, pp. 253-313. 
Figure 4 The first beguine communities in Brabant-Liège (c. 1200-c. 1230)

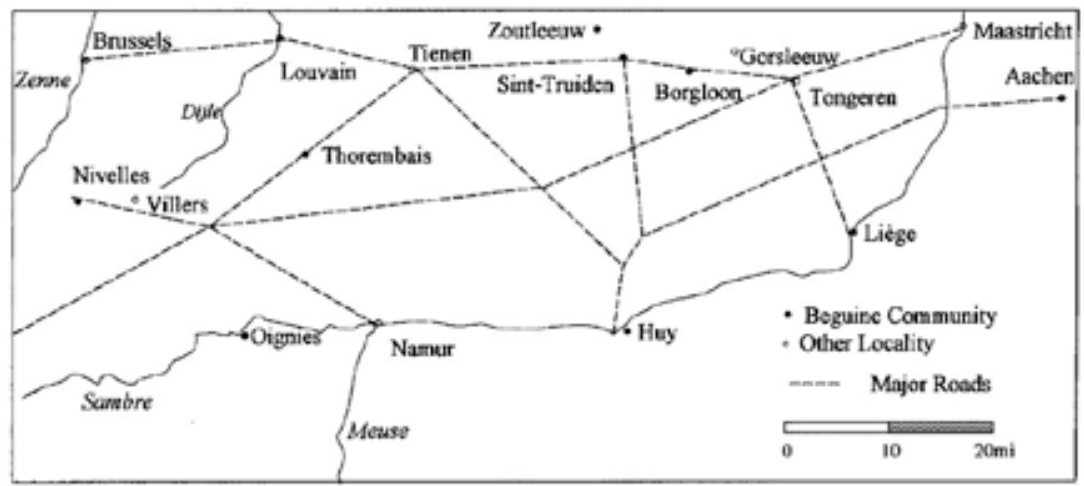

Reprinted with permission of the University of Pennsylvania Press, from Walter Simons, Cities of Ladies: Beguine Communities in the Medieval Low Countries, 1200-1565 (Philadelphia: University of Pennsylvania Press, 2001), p. 45

Saint-Denis, collegiate church of Liège; d. 1233), Guido of Nivelles (chaplain at Willambroux leprosarium until c. 1207; minister at Saint-Sepulchre hospital's chapel and serving nearby beguines until his death; brother-in-law of Marie of Oignies; d. 1227), and Thomas of Cantimpré (Augustinian canon regular at Cantimpré, 1217-1232; Dominican friar; subprior at the Dominican house in Louvain $c .1246$; d. c. 1272). ${ }^{53}$ The support offered by such men came in the form of acting as clerical advisers to beguinages, and/or writing laudatory and essentially propagandistic vitae chronicling the exemplary lives of certain virtuous beguines. Additionally, many beguinages were the recipients of support from ecclesiastical authorities in the form of episcopal charters. $^{54}$

In October 1216, Jacques of Vitry reports in a letter to friends a conversation with Honorius III on the topic of beguines. The Pope gives his blessing to beguines, Jacques witnesses, permitting these women 'not only in the diocese of Liège but also in France and the Empire, to live in the same house and to incite each other toward the good by mutual exhortations'. ${ }^{55}$ This was a crucial turning point in the acceptance of these religious women living

53 Simons, Cities, pp. 38-48. Guido of Nivelles should not be confused with Giles, one of the founders of Oignies' priory, or John of Nivelles: ibid., p. 47; VMOSuppEng, p. 137, n. 1.

54 Simons, 'Margins', p. 321.

55 Translation from ibid., p. 321, n. 30. 'ut liceret mulieribus religiosis non solum in episcopatu Leodi[n]ensi, sed tam in regno quam in imperio in eadem domo simul manere et sese invicem mutuis exhortationibus ad bonum invitare'. Huygens (ed.), letter I, p. 74, ll. 78-81. The news is not altogether positive, however: see below, Chapter 3, p. 156. 
without monastic affiliation, and thus of central importance to the acceptance of this way of life as an authorized form of female piety..$^{56}$ This proved to be the high point of the beguine phenomenon. In response to the growing numbers of women adopting the new lifestyle and thereby attaining 'a spiritual freedom' ('une liberté spirituelle'), the Church imposed sanctions for greater control in the early fourteenth century. ${ }^{57}$ The beguines were conflated with the Free Spirit heretics and accused of antinomianism..$^{8}$ Marguerite Porete, a beguine from Hainaut and author of Le Mirouer des simples ames, was executed in 1310 as authorities perceived her vernacular text to be promulgating the Free Spirit heterodoxy. ${ }^{59}$ The decree Ad nostrum qui from the Council of Vienne (1311-1312) listed eight characteristics of the beguine lifestyle which corresponded to the fundamental elements of the Free Spirit heresy. ${ }^{60}$ Ultimately, the Council condemned the beguines in a special decree, Cum de quibusdam mulieribus ${ }^{61}$ The decree's oppositional stance was repeated in another bull, Ratio recta, disseminated on 13 August 1318 by John XXII. ${ }^{62}$ Though the Church acknowledged that there could be pious uncloistered religious women, remaining beguines were constantly subject to interrogations for heretical behaviour. The dynamic piety exemplified by the holy Liégeoises became, for the most part, a thing of the past.

There is scant historical documentation for early communities of beguines in the Low Countries. The vast majority of our knowledge about the movement is derived from study of the biographies, though the texts are not necessarily authentic representations of the beguine lifestyle. Scholars tend to group the biographies together as a group of beguinal vitae, which is technically inaccurate, as Walter Simons observes: 'most of these women were beguines only for a short while before their conversion to a traditional monastic life and ended their lives as nuns, following a rule in a monastic setting, ${ }^{6}{ }^{6}$ I contend that the term 'beguine' is not an official status per se, but operates instead as a shifting discursive grouping, characterized by a variety of motifs which can be interpreted negatively or positively depending on

56 Wogan-Browne and Henneau, p. 5 .

57 My translation; Bartoli, p. 61.

$5^{8}$ Simons, Cities, pp.120-21. On the Free Spirit heresy, including its intersection with beguinal piety, see in particular: Lerner.

59 On Marguerite, see in particular: M. Brown, pp. 191-216; Hollywood, pp. 87-119.

6 o Fredericq (ed.), I, pp. 168-69, no. 172 (Latin); Denzinger (ed.), pp. 288-89, DS 891-99 (English translation). Flory, pp. 63-64.

61 Fredericq(ed.), I, pp. 167-68, no. 171 (Latin); McDonnell, Beguines, p. 524(English translation).

62 Fredericq (ed.), II, pp. 72-74, no. 44. Simons, Cities, p. 133.

63 Cities, p. 37. 
particular biases. In this sense, all the Liégeoises under discussion in the present study are beguines.

Five of the vitae explicitly refer to beguines, allowing for insight into the circulating meaning of the term in the period ${ }^{64}$ The texts repeatedly portray contact with the uncloistered groups as foundational to the spiritual life and development of the female protagonist, though clearly positioning the holy Liégeoises as 'not beguine'. Aged seven, Beatrice of Nazareth temporarily joins a group of beguines in Léau to develop her pious education. ${ }^{65}$ Similarly, Ida of Léau frequently and eagerly visits local beguines for instructive conversation. ${ }^{66}$ After being forced out of three Cistercian institutions, Juliana of Mont-Cornillon finds temporary sanctuary with a group of destitute beguines in Namur during her second exile from home in $1248 .{ }^{67}$ Notably, such episodes of contact with identified beguines are transitional and transitory. Juliana's beguine lifestyle does not last long. By 1252, Juliana and her last remaining companion, Isabelle of Huy (herself a former beguine), transfer to Salzinnes Abbey as they are too frail to live in the world. ${ }^{68}$ Beatrice spends only a year with the beguines, a period in which she is mercilessly mocked by fellow students for her zealous self-discipline. ${ }^{69}$ The beguine community, though educational, is not a site in which Beatrice can become spiritually perfect: she joins the Cistercian Order in Florival the following year..$^{70}$ This transferral is categorized by Bartholomew, Beatrice's father, as her 'total conversion' ('omnimoda sui conuersione'), suggesting that the beguine lifestyle, at least in his eyes, is only a partial uptake of the religious life. ${ }^{71}$ Ida of Léau also eschews the beguine life in favour of becoming a Cistercian nun in La Ramée. ${ }^{72}$

Jennifer N. Brown asserts that the term 'beguine' is often used in modern scholarship as an 'umbrella term', encompassing any medieval woman

$64 V B N, 1.3 .20 .24 ;$ VILéau, 1.11.110; VILov, 1.5.27-28.165; 1.5.31-35.166-67; 1.6.39.168; 2.2.6.172; VJC, 1.4.17.450; 1.6.36.455; 1.6.38.455-56; 1.6.41.456; 2.2.8.460; 2.6.32.469-70; 2.9.53.476-77. Though there is no evidence of direct contact with beguines in her vita, Marie of Oignies also refers positively to beguines in the Liège diocese: $V M O, 2.6 .57 .651 ; 2.11 .101 .663$.

$65 V B N, 1.3 .20-22.24-26$.

66 VILéau, 1.11.110.

67 VJC, 2.3.32.469-70.

68 Ibid., 2.6.33.470.

$69 V B N, 1.3 .21 .26$.

70 Ibid., 1.4.23.28.

71 Beguines are repeatedly depicted as witnesses of the holy women's extraordinary piety rather than as particularly holy women themselves. See: VILov, 1.5.27-28.165; 1.5.31-35.166-67; 1.6.39.168; VJC, 1.6.36.455; 1.6.38.455-56; 1.6.41.456; 2.2.8.46o.

72 VILéau, 2.13.112. 
devoting herself to religion, whether or not the woman herself - or those in her community - would necessarily have used this label. ${ }^{73}$ It is clear that the Liégeoises viewed themselves as distinct from beguines, or at least their biographies depict them in this manner. The women themselves, and their clerical supporters, shun this label, preferring instead more positive descriptors, including 'religious women' ('mulieres religiosae', 'religiosae feminiae'), 'sacred virgins' ('sanctae virgines'), 'sacred women' ('mulieres sanctae'), and 'chaste virgins' ('virgines continentes'). ${ }^{74}$ Jacques of Vitry, for example, rejects the term 'beguine' when describing Marie of Oignies, opting for 'mulier religiosa' instead. ${ }^{75}$ Marie of Oignies is repeatedly referred to as 'benigna' ('good', 'kind') in her liturgical office, which Daniel Misonne and Hugh Feiss take to be a simple replacement for the word 'beguine'. ${ }^{6}$ The word replacement, however transparent, skirts a definitive identification of Marie as a beguine. Nevertheless, the correlation between many characteristics of Marie's lifestyle and those of the women explicitly named as beguines remains.

As the contents of the Holy Fathers' texts offer endless examples for the pious, Jacques affirms that Marie's life is a text to be read for pious inspiration: 'Then you belched forth many and wondrous readings from a wondrous and unheard of fullness and, had we been able to understand, you read to us from the book of life [de libro Vitae], suddenly changing from a disciple into a master. ${ }^{77}$ Drawing from this passage, Anneke B. Mulder-Bakker proposes a new label for the corpus biographies: 'libri vitae' ('books of life'). ${ }^{78}$ She argues persuasively that the Brabant-Liège biographies are not, sensu stricto, hagiographies. Rather, they are 'books of life', with living saintly protagonists. The Bollandist Hippolyte Delehaye formulates the traditional definition of hagiographal works as: 'any written monument inspired by the cult of saints and aimed at its promotion' ('tout monument écrit inspiré par le culte

73 'Introduction', p. 2.

74 Simons, Cities, p. 36.

75 J. N. Brown, 'Introduction', p. 2.

76 VMOOL, pp. 181-82, 187. For Misonne and Feiss' comments, see VMOOL, p. 178; VMOOLEng, p. 185 , n. 1 .

77 VMOEng, 2.5.48.84. 'tunc demum à [corde] puro \& ebrio extorque batur veritas; tunc mira \& inaudita de plenitudine eructans de libro Vitae, si possemus capere, multas \& mirabiles lectiones, de discipula in magistram subito conversa, nobis legebas.' $V M O, 2.5 \cdot 48.649$. See also reference to the book of life in Revelations 20.12, and Ida of Nivelles' vision of a similar book: VIN, 18.241-43.

78 'Laywomen', pp. 32-33. On this, see also: Anchoresses, pp. 194-99; 'Experience', pp. 94101. On the 'book of life' as Christ and in visions in the corpus, see below: pp. 138 and 206 respectively. 
des saints, et destiné à le promouvoir'). ${ }^{79}$ Hagiographic documents aim at veneration of their protagonists, a process which could solidify after their death by canonization. Yet, none of the Liégeoises were ever considered for canonization, nor did they secure a lasting, significant cult. ${ }^{80}$ Furthermore, several scholars point out that Elisabeth of Spalbeek's biography is not a vita per se but instead a probatio - a document that typically records tests of an individual's holiness - more an interrogation of piety than a laudatory hagiographic text. ${ }^{81}$ It is with Mulder-Bakker's specific nuance that I use the terms 'vita' and 'hagiography' throughout this book: relating to texts detailing the spiritual adventures of living (non-canonized) saints.

In response to the conflation of 'beguine' with 'mulier religiosa' evident in much scholarship, Mulder-Bakker unpacks the latter term, generating three broad subsets: (1) holy virgins and beguines; (2) holy matrons, widows (and holy knights); (3) anchoresses and hermits. ${ }^{82}$ This framework allows for a recognition of the lifestyle differences in the corpus, and offers a taxonomy which deals well with the mobility on display in the vitae. For example, Marie of Oignies and Yvette of Huy were both widows and entered anchorholds - thereby variously positioned in sets (2) and (3). ${ }^{8_{3}}$ MulderBakker's scheme consciously focuses on holy laywomen, and thus excludes the nuns Alice of Schaerbeek, Beatrice of Nazareth, the three Idas, and Lutgard of Aywières. ${ }^{84}$ These nuns exhibit the same type of religious activities as their unenclosed counterparts. The similarity of worship practices between the cloistered and non-cloistered women is noteworthy, and must be taken into account. Thus, I expand Mulder-Bakker's framework to add a fourth category for monastics, and use the term 'mulier religiosa' or 'holy woman' for all the women in the corpus. A further nuance must be added to Mulder-Bakker's typology. In set (1), no distinction is made between 'institutionalized' beguines (those living in beguinages) and beguines who live alone, or in less formalized groups. ${ }^{85}$ The latter most often appear in the corpus of Netherlandish Lives. Whilst the holy Liégeoises are taken to be archetypes of the beguine lifestyle, they are in fact explicitly extraordinary. Not every beguine can become a living saint, after all.

P. 2; my translation.

80 Mulder-Bakker, 'Laywomen', pp. 30-33; 'Invention', pp. 10-11. On the medieval canonization process, see in particular: Mulder-Bakker, 'Invention'; Vauchez, Sainthood, pp. 22-84.

81 Elliott, Woman, pp. 186-89; Njus, pp. 297-300.

82 'Laywomen', pp. 10-27; Spencer-Hall, 'Review of Living Saints', pp. 55-56.

83 Mulder-Bakker, 'Laywomen', pp. 19, 21.

84 Ibid., p. 12.

85 Galloway; Ziegler, pp. 113, 118-23. 
Beguinage regulations 'bonded all [residents] together', despite differences relating to social class, age, or personal experiences ${ }^{86}$ Such rules created a cohesive community, less threatening to the Church due to its supervision by clergymen and a rigid hierarchy. Moreover, women could finally be identified as beguines just by looking at them, in theory at least. ${ }^{87}$ As beguinages became more commonplace in the thirteenth century, clerics increasingly viewed their female residents as the 'better kind' of beguine. ${ }^{88}$ The beguinage minimizes the inherent problem of classification posed by the lay female religious. By contrast, a significant hallmark in the lives of all the Liégeoises is resistance to integration into a coherent group. This is most often testified by significant tension between the Liégeoises and the rest of the community, be that monastic or lay. Jacques of Vitry conjures an atmosphere of bitter enmity towards the women in his prologue to Marie of Oignies' vita: 'You have seen and marvelled at those shameless men [...] who, hostile to all religion, maliciously slandered the religious life of these women and, like mad dogs, railed against customs which were contrary to theirs. ${ }^{\prime}{ }^{89}$ The texts provide many detailed elaborations of such hostility. Some women, for example, are reprimanded by spiritual superiors for excessive asceticism or urged strenuously to reduce their mortifications, including Beatrice of Nazareth, Juliana of Mont-Cornillon, Margaret of Ypres, and Yvette of Huy. ${ }^{90}$

Unlike the figure of the institutionalized beguine, a devout woman who enthusiastically obeys the rule of her beguinage, the Liégeoises find the strictures of formalized religious life difficult to bear. Official monastic rules are repeatedly depicted as obstacles to their preferred worship practices. Alice of Schaerbeek is initially overcome with grief when disallowed access to the chalice, and thus ingestion of the Lord's blood, due to her leprosy and the perceived danger of contagion..$^{91}$ Ida of Léau's disordered behaviour after reception of the Eucharist leads to a rule imposed on all nuns in the community: no nun who behaves in such a manner can take Communion..$^{92}$ In order to receive Communion when she enters Kerkom monastery, a rite not normally allowed to such junior members of the Order, Ida of Nivelles feigns

86 Ziegler, p. 114.

87 Miller, 'Name', p. 69.

88 McDonnell, Beguines, p. 127; Miller, 'Name', pp. 68-69.

89 VMOEng, prol. 4.43. 'Vidisti etiam \& admiratus es, [...], quosdam impudicos \& totius religionis inimicos homines, praedictarum mulierum religionem malitiose infamantes, \& canina rabie contra mores sibi contrarios oblatrantes'. $V M O$, prol. 4.637 .

$90 \quad V B N, 1.4 .26 .30-32 ; V M Y, 18.115 ;$ VJC, 1.1.4.445; 1.2.12.447; 1.3.15.447-48; VIH, 17.49.873.

91 VAS, 2.15 .480 .

92 VILéau, 2.19-20.113. On this episode, see also below, p. 76. 
acedia.$^{93}$ She is devastated that she cannot take Communion as established nuns do; she would rather have her head cut off a hundred times than endure further delay. ${ }^{94}$ Agnes, abbess of Aywières, prohibits Lutgard from taking the sacrament every Sunday. ${ }^{95}$ Lutgard's prediction of forthcoming divine punishment for denying her such grace comes true: Agnes falls seriously ill, and her sickness is only cured when she relaxes the prohibition. Lutgard's solution emphasizes her disjunction with the monastic community. Though present there, her membership in the choir of God's elect supersedes any association she might have with the foundation.

Members of the religious community are shown to be highly antagonistic to the holy women in their midst. A junior Dominican friar undertakes a diabolical plot against Ida of Louvain, accusing her of pregnancy. ${ }^{96}$ The pernicious gossip spreads far and wide, only halted after a friar's inspection of Ida's eyes to discover the truth of the matter. Ida of Nivelles suffers myriad slanderous attacks from those in La Ramée who disbelieve the authenticity of her displays of exemplary piety. ${ }^{97}$ Jealous nuns in the monastery of Saint-Catherine similarly disparage Lutgard for her devout way of life. ${ }^{98} \mathrm{~A}$ priest in Ypres mocks Margaret and drives her off when she seeks him out to find spiritual solace when her confessor, Zeger, is unavailable. ${ }^{99}$ Juliana of Mont-Cornillon is constantly beset by attacks from clerical and monastic quarters, including from the wicked prior John I of Mont-Cornillon, countless churchmen, and a faction of envious nuns. ${ }^{100}$ The persecution results in her twice being forced into exile from Mont-Cornillon. ${ }^{101}$

The laity similarly pour scorn on the holy women. Although Christina Mirabilis' outlandish behaviours, including three mystical deaths, are explicitly formulated as divinely ordained in her biography, the lay community of Sint-Truiden believe her a demoniac and persecute her. ${ }^{102}$

93 VIN, 3.208-09.

94 Ibid., 3.209-10. See also episode in which Ida ingests sacramental wafer intended for a sick woman: ibid., 20.249-50.

$95 V L A, 2.1 .14 .246$. See also Lutgard's prediction of divine vengeance for nuns who do not worship at canonical Hours: ibid., 3.2.14.259-6o; analysed below in Chapter 1, pp. 94-95.

96 VILov, 2.4.17-21.175-6. See further persecution in: ibid., 2.6.32.179-80.

97 VIN, 31.283; 32.284 .

$98 V L A, 1.1 .8 .238$. See similar examples in: ibid., 1.2.17.240.

$99 V M Y, 24.118$.

100 On John, see: VJC, 2.5.21-22.466; 2.6.31.469. On churchmen resistant to the institution of the Corpus Christi Feast inspired by Juliana's vision, see: ibid, 2.3.10.461-62. On the nuns, see: ibid., 1.6.40.456.

101 Ibid., 2.5.22.466; 2.6.28-31.468-69.

102 VCM, 2.20-21.653. 
A chronicle records King Philip III of France's (d. 1285) consultation of an unnamed religious woman, believed to be Elisabeth of Spalbeek, to discover if his wife was responsible for the fatal poisoning of his son. Any favourable gloss on the event as a sign of Elisabeth's good reputation in the region is undermined by the chronicler, who refers to her as a 'pseudo-prophetess' ('pseudoprophetessa'). ${ }^{103}$ The holy women's families are likewise often sources of hostility. Margaret of Ypres' biological sisters, for example, harshly upbraid their holy sibling for not following her confessor's command to sleep on one Christmas Eve. ${ }^{104}$ Ida of Louvain's kin strap her down three times in a single day, thinking her insane after her humble adoption of wretched garb. ${ }^{105}$ Marie of Oignies' parents mock her mercilessly when she eschews fine garments and adornments from early girlhood. ${ }^{106}$ Various relatives and worldly people condemn her and her husband for converting to chaste marriage and renouncing earthly possessions. ${ }^{107}$

As modern scholars struggle with a precise definition for the pious medieval woman - 'beguine', 'holy woman', and so on - similar strife is evident in clearly defining the limits of the corpus of devout Liégeoises. Critics agree that the biographies constitute a coherent textual collective, indicating a 'critical moment' in female engagement with new forms of spiritual practice. ${ }^{108}$ Neverthless, there remains little consensus as to the precise contours of the 'Holy Women of Liège' corpus. Particular trouble is caused by the inclusion or exclusion of the vitae of Odilia of Liège and Catherine of Louvain amongst the list of the twelve other women that I include in the present study. ${ }^{109}$ For example, Barbara Newman and Wybren Scheepsma include all fourteen women, but Michel Lauwers, and Margot

103 Guillaume of Nangis, p. 502. For details of Elisabeth's involvement in the affair, see Njus, pp. 310-16.

$104 V M Y, 18.115$.

105 VILov, 1.3.19.163. See also her sister's verbal attacks: ibid., 1.6.36-37.167-68.

106 VMO, 1.1.11.639.

107 Ibid., 1.1.15.640. On chaste marriage, see in particular: Elliott, Spiritual Marriage; Karras, pp. 45-52.

108 Wogan-Browne and Henneau, p. 8.

109 The three books of Odilia's Life are split across two publications: Vitae B. Odiliae; Vitae Odiliae liber III. For Catherine, see: De venerabili Catharina. This edition incorporates two versions of Catherine's life: Caesarius of Heisterbach, II, pp. 95-98; Thomas of Cantimpré, Bonum universale de apibus, pp. 295-98. For analyses of Catherine's life, and analyses, see: Goodich (ed.), Other Middle Ages, pp. 26-31; Kleinberg. She is also widely known as Catherine of Parc-aux-Dames, though she belonged not to the monastery of Parc-aux-Dames in northern France, but instead to Parc-les-Dames in Brabant, near Louvain. 
H. King with Ludo Jongen count only thirteen, eliding Odilia. ${ }^{10}$ Jennifer Carpenter and Jocelyn Wogan-Browne writing with Marie-Elisabeth Henneau concentrate only on the twelve Liégeoises included in this book. ${ }^{111}$

The criteria for inclusion in the corpus for the present study are: holy women resident in Brabant-Liège in the thirteenth century; shared narrative tropes and spiritual practices; evidence of contact between the women; interconnection of biographers; and medieval manuscript holdings grouping the collection. I disregard Catherine (neé Rachel) of Louvain as anomalous: she is the only convert to Christianity in the group. Further, her biography is exceedingly brief, focusing on the custody battle between Catherine's Jewish family and the Cistercian community of Louvain (also known as Vrouwenpark), to which the virgin flees. The text contains only one vision, provided with scant details, in which the young girl is visited by the Virgin Mary and told to leave her family home. With regards to Odilia, as Simons notes, her vita has far more emphasis on the ecclesiastical politics of the Liège diocese than attention to the specificities of religious life..$^{112}$ Moreover, her text is 'far from exceptional." ${ }^{113}$ The contours of Odilia's spirituality are very similar to that of Yvette of Huy, and she is thus excluded.

The twelve women in this book's corpus are expressly, and repeatedly, depicted as acting as spiritual advisers to one another in the vitae. For instance, Ida of Nivelles mentors a young Beatrice of Nazareth upon the latter's arrival at La Ramée, with Beatrice eventually considering Ida as her mother. ${ }^{114}$ Lutgard and Marie are also close spiritual allies. On her deathbed, Marie covers her head with Lutgard's veil and is touched by the spirit of prophecy. ${ }^{115}$ She predicts Lutgard's performance of copious bodily and spiritual miracles. After her death, Marie appears to her friend in a vision, asking for a favour. ${ }^{116}$ Christina Mirabilis also visits Lutgard in spirit to advise her to follow God and His desire for the saint to transfer to the Cistercian monastery of Aywières, instead of transferring to her preferred choice, Herkenrode. ${ }^{117}$

110 B. Newman, 'Preface', pp. xlviii-xlix; Scheepsma, p. 85; Lauwers, p. 63, n. 7; King and Jongen, n.p.

111 Carpenter, 'New Heaven'; Wogan-Browne and Henneau, pp. 7-8.

112 Cities, p. 38.

113 Mulder-Bakker, Anchoresses, p. 126.

$114 V B N$, 1.10.58-66; 1.11.57.70-72; 1.14.67.84; 3.1.188.218. See also the unnamed holy woman in Ida's vita, whom Martinus Cawley suggests could be Beatrice: VIN, 25.261; VINEng, p. 70, n. 117. For reference to Ida as mother, see: $V B N, 1.10 .60$.

$115 V L A, 2.1 .9 .245$. See also ibid., 3.3.18.261.

116 Ibid., 3.1.8.257-58.

117 Ibid., 1.2.22.242. 
The primary sources also reveal a network of contact between the women, mediated by individual figures. ${ }^{118}$ For example, Christina is also connected with Lutgard via the recluse Jutta of Borgloon (then known as Loon). Jutta receives Lutgard for a fortnight at some point before 1200, and later welcomes Christina in her home for a period of nine years, $c .1210-1218 .{ }^{119}$ St. Boniface (d. c. 1266) spends the last eighteen years of his life in La Cambre, Alice of Schaerbeek's home. ${ }^{120}$ For two years, both were resident in La Cambre at the same time (1248-1250). Boniface also acts as patron to Juliana of Mont-Cornillon and her spiritual sister Eve of Saint-Martin. ${ }^{121}$ His relics are transferred behind the high altar at Villers with those of Juliana and others in $1269 .{ }^{122}$ Venerable cleric Guiard of Laon (d. 1248) - archdeacon of Troyes (1215-1221); chancellor at Paris university (1237-1238); bishop of Cambrai (1238-1247) - connects Juliana, Lutgard, and Margaret. John of Lausanne (d. c. 1258-1263), a canon of Saint-Martin, discusses Juliana of Mont-Cornillon's momentous vision revealing the necessity of the institution of the Corpus Christi Feast with Guiard. ${ }^{123}$ In 1242, Guiard visits Juliana himself. ${ }^{124} \mathrm{He}$ later advises Juliana and her companions, then living unenclosed in exile from Mont-Cornillon at Namur (from c. 1247-1248). ${ }^{125}$ Guiard also visits Lutgard in Aywières, and is miraculously able to communicate with the holy woman despite a language barrier, as he speaks only French and she only Flemish. ${ }^{126}$ Margaret's confessor, Zeger of Lille, receives a summons from Guiard, though Zeger does not comply due to Margaret's ill health. ${ }^{127}$

There are also clear links between the vitae's authors. Thomas of Cantimpré writes three biographies (Christina, Lutgard, and Margaret), alongside a supplement to Jacques of Vitry's earlier Life of Marie. Thomas refers repeatedly to Jacques' biography of Marie in his vita of Lutgard. ${ }^{128} \mathrm{I}$ analyse the connections between Thomas and Jacques in Chapter $3 \cdot{ }^{129}$ The

118 Wogan-Browne and Henneau, p. 14.

$119 V L A, 1.2 .16 .240$; VLAEng, p. 231 n. 86; VCM, 4.38.657. Jeay and Garay misidentify the 'Ivetta' in the text here as Yvette of Huy: 'Strategies', p. 33. The explicit reference to Loon (approximately forty kilometres from Huy) directs us to identify the woman as Jutta instead, as in VCMEng, p. 125. 120 Smet and Tiron, p. 62.

121 Mulder-Bakker, 'Laywomen', p. 39.

122 VJCEng, p. 292, n. 462.

123 VJC, $2.2 .7 \cdot 459$.

124 Ibid., VJC, 2.5.25.467; VJCEng, p. 264, n. 35 o.

125 VJC, 2.6.33.470.

$126 V L A, 2 \cdot 3 \cdot 40.25^{2}$.

$127 V M Y, 14.113$.

$128 V L A, 1.2 .22 .242 ; 3.1 .5 .257 ; 3.1 .8 .257-58$.

129 See in particular pp. 160-61. 
composer of Ida of Nivelles' vita, Goswin of Bossut (d. after 126o) - cantor of Villers abbey, c. 1230-126o - also wrote Marie of Oignies' liturgical office. ${ }^{130}$ Ida's vita was written at the request of her patron, William of Dongelbert (or Dongebert; Dongelberg) (d.1242), abbot of Villers 1221-1237, later abbot of Clairvaux 1238-1239. ${ }^{131}$ William's governance of Villers coincides with Alice's early life, with her posited entry to the community of La Cambre, which was under Villers' paternity, occurring in 1227 , at the end of his tenure. ${ }^{132}$ William was also Elisabeth of Spalbeek's patron. ${ }^{133}$ Elisabeth's relative, William of Ryckel, abbot of Sint-Truiden, acted as her confessor. ${ }^{134} \mathrm{He}$ also translated Lutgard's Latin text into Middle Dutch. ${ }^{135}$

The Liège biographies were certainly viewed as a corpus in the medieval era, with no distinction made between the lives of women who were enclosed and those who lived in the world. Manuscript collections show the perceived interconnection of the texts. For example, a library catalogue dating to the seventeenth century reveals that the Abbey of Sint-Truiden housed the biographies of Christina Mirabilis, Ida of Léau, Ida of Nivelles, Lutgard of Aywières, Marie of Oignies, Margaret of Ypres, and Yvette of Huy. ${ }^{136}$ A seventeenth-century codex, now lost, contained the biographies of Yvette, and the Idas of Nivelles and Léau. ${ }^{137}$ From the same period, the lives of Christina, Elisabeth, Lutgard, and Yvette were bundled together into a manuscript, still extant..$^{138}$

130 VMOOL; VMOOLEng; Cawley, 'Introduction [to SMG]', pp. 6-8). Goswin's dates of birth and death are unknown, and the date of his accession to cantor is uncertain. However, records testify that he was replaced as cantor in 1260 , hence the likely death date.

131 VINApp, prol. 222; VINEng, prol. B.29; Cawley, 'Introduction [to SMG]', pp. 3-4, 26. The prologue is absent from VIN, but is extant in two MSS in divergent forms: Brussels, BRB, MSS 8609-862o, fols. $146^{\mathrm{r}}-178^{\mathrm{v}}(\mathrm{A})$ and MSS $8895^{-88} 896$, fols. $1^{\mathrm{r}}-35^{\mathrm{v}}(\mathrm{B})$. Prologues $\mathrm{A}$ and $\mathrm{B}$ are reproduced in VINApp.

132 Cawley, 'Introduction [in VAS]', p. xiii.

133 Mulder-Bakker, 'Laywomen', p. 39.

$134 V E S, 18.373 ; 21.375 ; 23.376$. Njus, pp. 286-90. It is unclear as to how Elisabeth and William are related - the relevant text reads 'secundum carnem cognatæ', which Ziegler and Vodoklys translate loosely as 'uncle': VES,18.373; VESEng, 18.3, n. 119. As VESEng is in the form of an unpublished MS Word document with unstable pagination, all references to this work relate to numbering of chapters and subsections (respectively) established by the translators.

135 Mulder-Bakker, 'Laywomen', pp. 39-40.

${ }_{13} 6$ Sint-Truiden Abbey Library Catalogue, Brussels, Bibliothèque des Bollandistes, MS 98, fol. $345^{\mathrm{v}}$; Mulder-Bakker, 'Laywomen', 39; VIHEng, p. 72, n. 1. None of the indicated manuscripts are extant.

137 This codex was the source of the first edition of VIH by Chrysostomus Henriquez in 1633, and the Bollandists' edition from 1642 .

138 Collection of Latin Hagiographies, Trier, Stadtbibliothek, MS 1179. 


\section{A Collective Audience}

Mulder-Bakker's canon of thirteenth-century southern Netherlandish female vitae includes the urban anchoress Margaret of Magdeburg (c.12101250), clearly not resident in the Brabant-Liège region. ${ }^{139}$ As with some of the more commonly referenced 'core' holy women, Margaret's biographer refers to beguines and uses the reference in a similar way: Margaret's superior piety is highlighted. ${ }^{40}$ There is also evidence the work had an audience in the medieval Southern Netherlands. ${ }^{141}$ Mulder-Bakker thus argues for an appreciation of the dynamic interchange between Brabant-Liège and farther afield, in this instance Saxony. ${ }^{142}$ The thematic - as opposed to geographic grouping is strengthened by an appreciation of the mobility of the religious lifestyle in the period. In a sermon to virgins and young girls from his Sermones ad status collection (edited 1229-1240), Jacques of Vitry observes similarities between groups of religious women across thirteenth-century Europe: 'This [beguine] is what they are called in Flanders and Brabant, or Papelarda, just as they are called in France, or Humiliata as they say in Lombardy, or Bizoke just as they say in Italy, or Coquennunne as they say in Germany. ${ }^{143}$ Jacques views the women as a collective, united in the practice of a particular kind of religious worship across linguistic and geographic divides. This is opposed to the predominant approach in modern scholarship: consideration of texts from a single geographic or language area. As Anke Gilleir and Alicia C. Montoya remark, such modern studies thus 'follow the lines of thought that were set out in the nineteenth century, when the nation-state became the dominant framework for the study of modern literatures.' ${ }^{144} \mathrm{~A}$ medieval perspective would be different. For example, the English Benedictine chronicler Matthew Paris (d. 1259) commented that a multitude of women were undertaking a new form of uncloistered religious

139 'Laywomen', p. 6.

140 Johannes of Magdeburg, The Life of Margaret the Lame, 66.388; Die Vita der Margareta contracta, 66.88-92 On Margaret, see in particular: Mulder-Bakker, Anchoresses, pp. 148-73.

141 Mulder-Bakker, 'Laywomen', pp. 6, 33.

142 Anchoresses, p. 157.

143 Muessig, Faces, 'Second Sermon to Virgins and Young Girls', section 4, p. 89. 'sic enim nominantur in Flandria et Brabancia, - vel Papelarda - sic enim appellantur in Francia -, vel Humiliata - sicut dicitur in Lumbardia, - uel Bizoke - secundum quod dicitur in Ytalia -, vel Coquennunne - ut dicitur in Theotonia'. Muessig, Faces, p. 143, n. 242. On the bizzoche (also known as pinzochere), see in particular: Guarnieri; Mazzonis, pp. 2-9; Papi; Sensi. On German beguines, see in particular: Deane; Weiß. For a discussion of fourteenth-century Swedish beguines, see: Morris, pp. 161-70.

144 P. 2. 
life 'mostly in Germany' ('in Alemannia praecipue'), an area which appears to include the imperial regions of the Low Countries. ${ }^{145}$

What's more, bracketing off the 'beguine phenomenon' exclusively, or primarily, to the period c.1200-1350 obfuscates the importance of these holy women as models for later non-traditional female religious. ${ }^{146}$ For example, in a study of a sixteenth-century Dominican tertiary and visionary from Castile, María de Santo Domingo (c.1480/86-1524), Rebeca Sanmartín Bastida underscores the parallels between María's religiosity and those of her spiritual forebears, including the holy Liégeoises ${ }^{147}$ Lay female religious in modern-day Italy and Spain rose to prominence in the fifteenth century, and were particularly active in their communities until the seventeenth century. ${ }^{148}$ Simply put, these women - known as 'beatas' - are beguines by yet another name. Their spiritual and visionary practices broadly mirror their Northern European counterparts. In Chapter 3, I analyse the ways in which fifteenth-century Englishwoman Margery Kempe (d. after 1438) explicitly drew on Marie of Oignies as a spiritual model.

The above remarks trace, all too briefly, the ways in which the 'beguine' movement must be understood as a pan-European phenomenon, with lasting resonance for women even outside of Brabant-Liège and beyond the thirteenth century. My point is not that all medieval holy women are the same, or that their practices are identical. Context is key. Each woman's religiosity is inflected by her circumstances, both at the micro-level (the specificities of her life) and at the macro-level (the socio-political and cultural framework that she inhabits). Yet, the fact remains: the shared 'visionary, ecstatic, excessive aspects' of the women's religiosity bind them together in a form of community. ${ }^{149}$

Through their visions, the holy women form a 'collective audience' for the divine. Membership in this audience does not mean that all women see God in the same place or the same time, or even in the same way. But, crucially, all have access to the source material. For example, I saw Beauty

145 Luard (ed.), IV (1877), 278. Cited in Simons, 'Survey', p. 625.

146 Northern European beguines did not vanish after this period, but the lifestyle was certainly in decline and women were ever more subject to institutional constraints. Beguines experienced a relative resurgence in the seventeenth century: Simons, Cities, pp. 138-41.

147 Representación, pp. 17-82, in particular 21-22, 24, 26, 33, 39-44. On this, see also: 'Construcción'; 'Herencia'. For a depth study of María de Santo Domingo, see: Bastida and Balbás (eds.), pp. 13-88. On Castilian beguines, see also: Cantavella, pp. 69-73; Jiménez.

148 On such women in the Crown of Aragon, see in particular: Pou y Martí; Toro. On the beatas in València, see in particular: Perarnau i Espelt; Vela and Lizondo. On the beatas in sixteenth- and seventeenth-century Spain, see: Giordano; Keitt, pp. 91-113.

149 McGinn, p. 30. 
and the Beast as a child in a movie theatre. A friend watched the film for the first time on DVD as an adult. My goddaughter watches the film as streamed content on an iPad. We have all seen the movie, though we have never seen the film together. Indeed, we have encountered the movie in very different spectatorial contexts which inarguably impact our reception of it. Nevertheless, the three of us are joined together as a 'collective audience', a grouping constituted by the fact that we have all seen the same film. In fact, all those who have ever seen the Disney flick are united in this 'collective audience'.

For the majority of this book, I discuss the Liégeoises' religious visions in terms of cinema spectatorship, i.e. watching a film in a movie theatre. But there is no singular iteration of film viewership. The holy Liégeoises see God in the cinema theatre, but other beguines have different viewing situations. Movie theatres beyond the diocese offer a different viewing experience. Perhaps they have smaller screens, or more comfortable seats. And for various reasons, women beyond thirteenth-century Brabant-Liège may prefer, or be compelled, to view the divine film in a different format. The thirteenth-century Liégeoises were the earliest members of the 'collective audience' of visionary beguinal piety, the first to take their seats in the movie theatre(s) screening God's magnificence. The concept of the 'collective audience' - an assembly of individuals who all see the divine film but with different viewing times and circumstances - permits the analytical insights of the current study to be transferred to other works of medieval hagiography.

Nevertheless, it is clear that Brabant-Liège was the crucible for the beguine lifestyle, or at least the texts present the situation in this manner. In particular, Marie of Oignies is positioned as the original holy Liégeoise, and her biography is identified as the first text representing 'a much wider phenomenon'. ${ }^{\circ}{ }^{\circ}$ She is singled out by Jacques as a 'surpassingly excellent pearl' ('pretiosa \& praeexcellente margarita'), a 'jewel among other stones' ('carbunculus inter alios lapides'), and a 'sun' ('sol') amongst the other holy 'stars' ('stellas'). ${ }^{.51}$ As the beguinal archetype, Marie of Oignies sits in the front row at the premiere of the divine film. Other Liégeoises may drift into their local theatre alone on a sunny afternoon, or for a late-night screening with friends. Crucially, however, the movie theatres in Brabant-Liège all offer a roughly similar customer experience, as if all part of the same local franchise or chain. We can thus more confidently generalize their 
spectatorial experiences as forming a coherent set. In the preceding theorization of holy women as a collective audience, I posit God as constituting the film at which they direct their spectatorial attention. I move now to delineate the ways in which McGinn sets out hagiography as a whole as filmic.

\section{Cinematic Hagiography}

McGinn's first assertion as to the filmic nature of hagiography is founded upon the fusion of 'communication and entertainment' in both media. ${ }^{152} \mathrm{He}$ sounds a note of caution, though: 'If films intend primarily to entertain, vitae may at times entertain but always in the service of instruction.' The latter is emphasized in Marie of Oignies' vita. Jacques of Vitry gives Hugolino of Segni - bishop of Ostia and future pontiff Gregory IX - Marie's vita specifically because it contains 'most telling examples' ('exemplis evidentissimis'). ${ }^{.53}$ Those plagued by an overweening spirit of blasphemy, such as the bishop himself, can more easily be (re)inspired to faith with the many striking miraculous episodes from Marie's life than reasoned theological counsel. In the prologue to Marie's vita, Jacques explains the educative, exemplary value of hagiography as follows:

They [the holy Fathers] therefore put down in writing the virtues and the works of the saints who went before them for the use of those coming afterwards in order to strengthen the faith of the weak, instruct the unlearned, incite the sluggish, stir up the devout to imitation, and confute the rebellious and the unfaithful. [...] In this way, many who are not moved by commands are stirred to action by examples. ${ }^{154}$

Readers and listeners of hagiography should be moved to greater piety because of the example of the saint's life and works transmitted in such texts. Such examples, conveyed by vivid and rich imagery, are more effective than a dry theological sermon in attracting the attention of the lay community to religious matters. Jacques is motivated to write the vita, we are

152 P. 20.

153 VMOSuppEng, 3.16.154; VMOSupp, 3.16.672.

154 VMOEng, prol. 1.40-41. 'ad utilitatem sequentium, virtutes \& opera Sanctorum praecedentium redegerunt in scriptum, ut infirmorum fidem roborarent, indoctos instruerent, pigros incitarent, devotos ad imitationem provocarent, rebelles \& infideles confutarent. [...] Multi enim incitantur exemplis, qui non moventur praeceptis.' $V M O$, prol. 1.636. 
told, because of its 'utility to the many people who will read it' (multorum etiam legentium utilitate incitatus'). ${ }^{.55}$

Hagiographic texts function as vehicles to instruct their audiences as to how to become better Christians by modelling their behaviour on the pious devotion of saints, if not going quite as far as saints in terms of asceticism and so on. Similarly, films - as with all forms of address - instruct spectators how to behave, think, and feel, albeit often implicitly. ${ }^{156}$ The link between films and hagiography as ways to impart social/cultural/religious mores is significant as both fictional film and hagiography are designed to be entertaining, and often contain fantastical elements. Although cinema may not be presented to its consumers as a means to learn how to fit in with society, to adopt the correct moral code and even cultural mores, it nevertheless can - and does - function in this way. An entertaining narrative acts as a spoonful, or bucketful, of sugar to make the ideological medicine go down. Hagiography and cinema are both educative: hagiography avowedly so, and cinema in a more tacit fashion. Whilst literary texts may function ideologically, the reader can look away from the page, away from the propagandistic narrative. Cinema spectatorship, by comparison, is immersive; in the cinema, one is captive to the projector's unstoppable whirr. Moreover, cinema-going is often coded as an ideologically neutral event of pure escapism or shared entertainment, a family-friendly activity or good option for a date night. As such, cinema - outside of academia seems less freighted with the need to parse ideological messaging, to resist propaganda, and to engage our higher levels of analytical judgement. As with hagiography, the privileging of entertainment at the cinema allows for deeply persuasive socio-cultural 'education'.

The same patterns of behaviour, forms of devotion, and even personalities occur again and again in hagiography. There is a model of holiness to which one must conform. As McGinn says, 'certain modes of representation remain characteristic of the whole'. ${ }^{157}$ In thirteenth-century female saints' lives, certain components of sanctity repeat. These include visions, miracles, spiritual meditation, asceticism, and dynamic community service. The frequency of such behaviours across the Liégeoise corpus is central to the capacity for us to group the holy women together at all. ${ }^{15^{8}}$ An individual hagiographer tailored the precise manifestation of such components to suit his task at

155 VMOEng, prol. 10.49; VMO, prol. 10.638.

156 Hughes.

157 P. 20.

158 Petroff, Body, p. 162. 
hand, what needed to be said and proved about the subject of his text. Biblical texts, models from earlier spiritual biographies, and even chunks of previous hagiographies were regularly incorporated into the 'new' vita. Explicit signposting of the similarities between the saint in the 'new' vita and her devout forbears, recognized as holy, encouraged an acknowledgment of her own sanctity. Detailing Ida of Louvain's miraculous ability to summon flocks of poultry to attend a religious service to keep her company, her biographer exclaims: 'Wondrous thing! A thing scarce belonging to our times! A thing fit to be grouped with Saints' tales of old!'159 Ida's connection with the saints of years gone by legitimizes her own saintly classification.

Cinema spectators are similarly adept at recognizing the conventional tropes and patterns of the genre or character configuration of a given film and thereby anticipating its theme, mood, and message. Elements of filmmaking, such as lighting, editing, music, and so on, also all contribute to the creation of a distinctive style to a genre. Additionally, actors are often typecast, or perhaps simply choose a certain type of role to play again and again. A crucial difference between the static convention of character in some literary genres and in fiction film is the role of the reader/viewer's imagination. Despite the fact that the character in question may behave in exactly the same manner as every other character in the genre, the reader is allowed to imagine a plethora of specificities, most notably outward appearance. In comparison, the moviegoer is stuck with an individual who is identifiable across films and in different parts. Indeed, it is fundamental to the sense of surprise if an actor chooses to break out of their given mould. Hagiographic tropes operate according to the schema of recognisability in film, as opposed to literature: the hand of God is eternally present in saints' lives, and the saint is always identifiable.

McGinn maintains that there is a significant correlation between the relationship of reality and illusion in cinema and in saints' lives. He develops his hypothesis, stating:

Some pieces of hagiography, like cinéma vérité, do their best to imitate the appearance of reality, though the modern reader should not confuse this form of representation with real life, any more than we would do in the case of films that pretend to imitate everyday occurrences. Most saints' lives, however, involve a heightening of the presentation of the events according to certain conventions that were as well understood by

159 VILovEng, 1.13.3od.26. 'Res mira, nostrisque temporibus quanto magis inusitata, tato dignius inter antiqua Sanctorum miracula recitanda.' VILov, 1.5·30.166. 
their medieval audience as the adaptations of reality that contemporary viewers accept in film. ${ }^{160}$

Conventionally stylized depictions of saintly behaviour, as discussed above, allow for saints to be recognized as holy. However, such conventionality does not necessarily preclude that such behaviour is authentic, or at least supposed to be perceived to be authentic. Saints' vitae are presented to their audience as factual accounts of extraordinary things.

Hagiographers strenuously emphasize the reliability of their sources and the eye-witness accounts they have used. Ida of Léau's biographer, for instance, shores up his tale from attacks impugning the veracity of his text by foregrounding his exemplary and numerous sources. ${ }^{161}$ Thomas of Cantimpré details the selection process he undertook when gathering source material for his biography of Lutgard of Aywières. ${ }^{162} \mathrm{He}$ has excluded material for which he could not find sufficient substantiation, we are told, and even events which are so miraculous that only the highly cultivated would be able to comprehend them. The very need for such insistence on direct testimony and factual evidence demonstrates the necessity for hagiographers to defend their texts from claims of fanciful confabulation and to justify extraordinary and implausible miracles. Nevertheless, claims of authenticity direct the reader on how they should interpret the text: as fact.

The status of the women as 'living saints' is a significant indicator of a discernable agenda, or at least one possible agenda, underpinning this insistence on factuality in the vitae. The women literally incarnate Catholic doctrine, vividly portraying in their lives the rectitude of theology ${ }^{163}$ Philip of Clairvaux expounds at the end of Elisabeth of Spalbeek's text: 'How inexcusable you are, $\mathrm{O}$ humanity, if arguments so dynamic and manifest do not excite you to a robust strengthening of [your] faith and a feeling

16o McGinn, p. 20. Elsewhere, McGinn spares two sentences to liken vitae featuring particularly odd paramystical phenomena to horror and/or science fiction film: ibid., pp. 161, 178. This comparison is based on the allegorical or dream-like nature of these genres, which allow for the exploration of spectators' pressing contemporary concerns in a safe filmic space. He refers specifically to the texts of Christina Mirabilis and the German beguine Christina of Stommeln (d. 1312). The latter's hagiographic corpus is somewhat complex; for details see: ibid., p. 407, n. 99-100; Coakley, pp. 90-92. For a reading of Christina Mirabilis' vita in connection to horror films (in the zombie genre), see: Spencer-Hall, 'Horror'.

161 VILéau, prol. 2-3.107-08.

$162 V L A$, prol. 234.

163 Mulder-Bakker, Anchoresses, p. 198. On this, see discussion in the Conclusion below, pp. 243-54. 
for charity and a zealous devotion!'164 This book interprets the 'dynamic and manifest' visionary episodes from the corpus, seeking to tease out 'authorized' readings, along with more subversive strands identifiable by reading against the grain.

In 2002, Mulder-Bakker made an urgent call for the revalorization of hagiography as a rich source of medievalist material: The message seems to be that "true medievalists" do not concern themselves with hagiographic sources, or if they do, it is only because they wish to study the earliest texts in the vernacular or are interested in folk beliefs and popular mentality. ${ }^{165}$ I maintain that hagiography is important precisely because it reflects the 'popular mentality' of medieval Catholics. Moreover, I contend that this 'popular mentality' is not reducible to an inherent medieval-ness. Medieval hagiography is certainly a product of its historical context. Nevertheless, it expresses and discusses many of the issues with which our contemporary popular culture grapples. Medieval hagiography's 'popular mentality' is constituted by altogether human, trans-chronological pre-occupations, as we shall see.

\section{Mysticism and Popular Culture}

It is entirely logical for the mystical to be expressed in, and exert itself as, cinema, at least according to Strieber and Kripal. The enduring force underlying mystical visions (the 'cosmic mind') has not changed over time, nor has its communicative desire diminished. It is a savvy interlocutor. It appears to us according to the 'visual grammar' which best 'fits our imagination' at a given socio-historical moment:

If a form of mind wanted to really influence, shape, or direct a culture, it would not bother with the culture's public arguments or politics. It would choose to work on the culture's deepest operating system. It would go to the place of dreams and visions. It would choose to work on the cultural imagination. ${ }^{166}$

In the medieval era, the Church and its theology were the 'place of dreams and visions' into which the mystical entity inserted itself to most effectively

164 VESEng, 30.3. 'Quam inexcusabilis es, o homo, si te ad robur fidei et caritatis affectum et devotionis studium tam viva et tam manifesta non excitant argumenta!' VES, 30.378.

165 'Invention', p. 5. See similar comments in Ogden, p. 15.

166 Ibid., pp. 22, 222-23. 
make contact. In the modern era, cinema dominates our formulation of the visionary, and the kinds of visual experience possible. Strieber himself turns to successive historically inflected 'visual grammars' to de-code his first paranormal visitations in December 1985. The preternatural events unfolded 'at once as a horror movie, a grim fairy tale, a nightmare, and a viscerally real, physically painful experience. ${ }^{167}$ Frantically struggling to understand what he is witnessing, and what is being done to him, the quality of Strieber's gaze shifts between 'visual grammars'. In the retelling, he lists these in a reverse chronological trajectory: moving from the cinematic (horror movie), to the folkloric (childish fairytale), to the psychological (nightmare), and finally to the pre-linguistic (the body itself). The divine mystical does not figure here, as Strieber is not inculcated in any institutional religion's cultural-spectatorial regime. He is not himself religous, nor does he live in a predominantly religious society which immerses him in its tenets. After the visitations, Strieber still refers to himself as 'secular', though this is, as Kripal remarks, inflected clearly by a notion of a soul-ful aspect to nature and the universe (i.e. the spiritual). ${ }^{68}$

It is striking that Strieber particularizes the filmic character of the visitations: they are not like any movie, but a 'horror movie'. This reflects, of course, the immense terror he felt during his deeply unpleasant encounter with the paranormal. But it also speaks to another important facet of the mystical as perceived in the filmic, at least from Kripal's perspective. Kripal maintains that the mystical today manifests itself in 'the form in which the imagination (and so the image) are given the freest and boldest reign: popular culture. ${ }^{169}$ The filmic horror genre is most often taken as an extension of popular tastes, a vulgar appetite for carnage onscreen. ${ }^{170}$ Most horror flicks achieve limited critical praise in terms of artistic value. Strieber's reference to the horror genre, then, reveals the way in which mystical concerns and forms are embedded in pop-cultural artefacts. Moreover, it exposes the ways in which we turn to pop culture in order to express our contemporary mystical, paranormal, and otherwise visionary experiences. ${ }^{171}$

167 Ibid., p. 27.

168 Ibid., p. 55 .

169 Kripal, Mutants, p. 5. See also: 'Secrets', p. 296.

170 On this, see: Williams; below, p. 112.

171 For a relevant, though potentially out-of date, case study, see: Meyer, 'Popular Cinema'. It is a widely held belief in Ghana that the supernatural can deleteriously influence the world of the living. The supernatural is the most favoured subject in Ghanian popular cinema, or at least this was the case when Meyer published her study in 2003. Thanks to the technology of 
Peter H. Aykroyd develops the premise of 'mystical pop culture' even further. He suggests that the materialization of the mystical depends on pop culture itself, on the very fact of its popularity:

Whether they were believers or skeptics or somewhere in between, those who have experienced psychical phenomena have been entertained. Frightened, amused, touched, moved. And aren't these precisely the emotions we want to experience when we attend a play, or see a movie, or go to a ballet? ${ }^{172}$

Pop culture is above all entertaining, or at least taken as such by a wide swathe of consumers. We immerse ourselves in such pop-culture media, allowing ourselves to be taken in by the latest blockbuster movie. We live in the filmic world for the movie's running time, and also drop our egological guard, suspending belief and investing ourselves in the filmic diegesis. This state actualizes, or liberates, moviegoers' latent psychical powers. Paranormal apparitions are thus 'a kind of spontaneous, unconscious projection of the psyches present'. ${ }^{173}$

Regardless of the actual validity of Aykroyd's theory, it is compelling, to a scholar of hagiography at least, given its insistence on entertainment as a foundation to mystical experience. It is taken for granted in scholarship that a typical work of medieval hagiography is both entertaining and educative. ${ }^{174}$ Indeed, the entertaining character of a tale is central to its spiritually instructive ultility, as discussed in the preceding section. For medieval hagiographers, audiences needed to be entertained in order to grasp the core religious message of a text. So doing, the text becomes transformative as an entertained and attentive audience will be moved to implement its religious lessons in their own lives. Aykroyd theorizes that being entertained unleashes the dormant parapsychological powers of an audience, leading to an exteriorization of their spiritual energy. In medieval hagiography, the entertainment factor produces deeper understanding of divinity. This effects in the reader both an interiorized and exteriorized

film and special effects, the invisible which haunts Ghanaian society can be made visible. The films Meyer analyses are wildly popular as they provide a space in which the supernatural can be evoked, confronted, and ultimately worked through.

172 Akyroyd and Narth, p. 183; cited in Kripal, Mutants, p. 5 .

173 Kripal, Mutants, p. 5 .

174 See, for example: Campbell, Lives, p. 12; Cazelles, Lady, pp. 4, 7; Herrick, p. 7; Petroff, Body, p. 162; Salih, p. 15 . 
manifestation of the text's 'spiritual energy' (central religious message) as the reader changes their spiritual-mental attitudes and their behaviour.

An appreciation for the interplay between pop culture and mysticism, or the perception of such an interplay in the public imagination, grounds the selection criteria for modern primary sources in the present study. Sources consulted in this book - including photography, film, TV, and digital content - are drawn, almost exclusively, from popular culture. By and large, this is media that has entertained the masses, problematically designated as 'low culture'. In sum, I am concerned with media favoured by the 'cultural laity'. Some works under discussion may also have been met with significant critical recognition, but their inclusion in my analyses rests on their broad popularity with 'ordinary' moviegoers and content consumers. Chapter 1, for example, features an extended discussion of The Dark Knight (Christopher Nolan, 2008). Nominated for eight Academy Awards, the movie was lauded by critics, including being widely hailed as one of the top ten films of the decade (2000-2009). ${ }^{175}$ More importantly, though, it was an immense commercial success with audiences, earning over a billion dollars in box offices worldwide. ${ }^{176}$

By comparison to today's media market, media consumers of days gone by had very little choice. Before the advent of the internet and digital streaming, for example, TV-viewers were subject to the whims of broadcast networks in terms of the shows to which they had access, and the time at which they could watch a given show. You tuned into a channel to be served with whatever product the 'televisual gods' decided to air at that slot. Moreover, these 'gods' had privileged access to the technologies of media production, with few consumers being able to lay hands on requisite equipment to produce media themselves. This has significantly changed, as such technologies, such as video recording and editing, have become significantly less costly and much more readily available. Every smartphone owner walks around with a camera, video recorder, and editing suite in their back pocket. The internet functions as a vast free distribution network for media produced by industry outsiders or amateurs. Technological development has lead to a narrowing of the traditional gap between media consumers and media producers, and a tension between the two forms of cultural production. I conceive of this as a tension between the 'cultural laity' and the 'cultural clergy'.

175 Dietz, n.p.

176 Box Office Mojo, n.p. 
In our current moment, the 'cultural laity' is playing an ever more active role in the production of media content. The control of the 'cultural clergy' over the means of media production has been progressively weakened, and as a result more 'low-brow' content is streaming out to the masses. The 'cultural clergy', then, comprises both traditional content producers and the critical elite, those who rule on matters of taste. The 'cultural clergy' is dependent for its existence on the 'cultural laity', and vice versa. Content producers need audiences, and cultural critics need someone to instruct, alongside a baseline of popular consumption from which they can extrapolate a hierarchy of cultural taste. Lay media producers depend on established modes of production to model their own processes and forms. What's more, the 'big players' of media production still control the rules of the game, by and large, thanks to their size and incredible reach across the global media marketplace. I consider this situation as analogous to the circumstances in which the medieval Liégeoises find themselves. The holy women are developers of a new kind of religious content for popular consumption, their vitae are pop-cultural devotional media. Nevertheless, the Liégeoises cannot escape clerical control entirely: their vitae are made to the model of religious figurations of how and in what ways women could be holy in the era.

In Chapters 3 and 4, I draw upon modern sources that cut to the heart of this shifting power dynamic between the 'cultural laity' and the 'cultural clergy'. Celebrities, especially in the Classic Hollywood model, are productions of the latter. A movie studio takes the raw potential of an individual and then processes, repackages that individual into a 'star'. People submit to this factory-style celebrification because of the immense pay-offs, fame and fortune. This model is being radically disrupted in the age of social media, and in the popularity of reality TV. Now, wannabe stars may package themselves, drum up a fanbase on social media, and gain significant airtime for just 'being themselves' on pseudo-documentary shows. In Chapter 3, I consider hagiography in terms of these modes of celebrity production, contrasting the successful celebrification of some holy women in hagiography to Margery Kempe's failed bid for holy recognition. In terms of modern celebrity, I am interested primarily in women whose careers and public personas reflect the different models of celebrification on offer, specifically Jessica Simpson and Kim Kardashian West. The former has been canonized, whilst the latter remains a lay saint. Simpson is not an A-list celebrity, but is certainly popular enough with the general public and viewed as a 'legitimate' star. Kardashian West is one of the most polarizing female figures in today's pop-culture ecosystem, subject to defamatory 
ridicule by detractors and breathless adoration by fans. I unpack the celebrification mechanics which underlie these very different expressions of modern celebrity, aligning them with the ways in which female identities are processed and produced in medieval hagiography.

In Chapter 4, I consider the ways in which media consumers produce themselves in and as media from a different angle. If Chapter 3 considers the 'macro-level' of mediatized identity production (celebrity writ large), then Chapter 4 scrutinizes its 'micro-level' (individualized representations for private consumption). I explore the ways in which contemporary Christians practise their religion in the online virtual world of Second Life (SL), with particular attention to the manner in which users choose to represent themselves with their avatar (a three-dimensional digital character). Much of the material in this chapter is derived from my own observations from spending time in SL, including details of interviews I conducted with SL Christians and examination of particularly arresting in-World religious imagery.

\section{Beyond the Frame}

William Germano observes that books 'are like photographs, possible only because the camera and the eye were fortunate to be somewhere at the very moment when the clouds held their shape just long enough. ${ }^{177}$ The photograph only records one version of the reality which lays beyond the lens, of the epistemological narrative which the photograph itself attempts to convey. The photographer's choices decisively impact the image with which a viewer is later presented. They control the focus and determine the frames of the final shot. The analyses in this book similarly bear the mark of my own perspective. In the chapters that follow, I offer my snapshot of the holy women of Liège, an image that emerged when the 'clouds' of medieval religion and modern film 'held their shape' before my eyes for 'just long enough' to be captured in writing. Two significant choices determine what lies 'beyond the frame' of the present study, and thus necessarily impact the broader signification of its findings. Firstly, I privilege textual representations of visual experience in the medieval corpus. Secondly, the vitae of holy men from thirteenth-century Brabant-Liège are explicitly excluded from this study. 
The focus on literary sources of medieval visuality in this book is both a practical and personal choice. The vast majority of scholarly work undertaken on the Liégeoises to date relates to their textual corpus. The Latin corpus has been edited to a high standard, and is relatively easily available in libraries. By contrast, it is difficult to identify a body of relevant images of the Liégeoises. In addition, it is challenging to discern a cohesive suite of images which were particularly popular with the holy women, with the notable exception of the Veronica icon. I discuss the vernicle at length in the Conclusion. Some insight has been shed on the artwork typically on display in beguinages, however. Joanna E. Ziegler demonstrates that these institutions favoured sculptural pieces with which women could enact publicly their intimate personal spiritual experiences. For example, small freestanding models of the Christ-child, known as the Christuskindje or Infant Jesus, were especially popular amongst beguines in Louvain and Mechelen in the early fifteenth century. ${ }^{17}$ Women interacted with the statue, tending to it as if it were their own divine child. This pattern of engagement offered an externalized form of affective response, replacing the fairly commonplace visionary motif of tending to the infant Christ found in vitae. Whilst ecstatic visionary experiences are a hallmark in the lives of Marie of Oignies et al., evidence suggests that ravishment was a rare occurrence for the vast majority of 'ordinary' women in beguinages. ${ }^{179}$ Indeed, institutionalized beguines were specifically encouraged to look outside themselves for devotional images, thereby dampening down the ecstatic potential of their religious practices. Whilst insight into the visual landscape of institutionalized beguines is certainly welcome, it is thus of limited utility as a means to reconstruct a bank of contemporary artwork to which the Liégeoises may have had particular attachment.

Little systematic study has yet been undertaken of manuscripts belonging to the Liégeoise corpus in terms of their illustrative content. It is my sincere hope that this project advances as rapidly as possible, thereby opening up new avenues of study into the holy women's visual processes, and the ways in which they themselves were visualized. In my own investigations into manuscript witnesses and accompanying pictorial content, I have been frustrated by the dearth of images. Admittedly, these investigations were superficial in terms of their limited scope: I have consulted a handful of manuscripts, and only those available digitized online. My intitial frustration at the lack of illustrated content, however, ultimately gave way to an 
appreciation for its effects. The vitae operate according to an impressive mechanics of virtuality.

Without recourse to a flat image (re)presenting a given scene from a saint's life, the reader turns more fully to the text itself. This necessitates an attentive and lingering gaze into the text, bringing about an immersive engagement in the vita's events which seem to be projected out from the manuscript to penetrate the reader's scopic horizon. This outward scopic propulsion into the panoramas conjured by the text entails a simultaneous inward movement, into the reader/viewer's own imaginative meditative capacity. The material form of the manuscript, then, acts as an agent for another kind of 'agape-ic encounter'. In some instances, the manuscript operates as the body of an other that textually meets the reader's probing gaze, with each 'looking' the other into more affirmative subject-hood. At other times, the manuscript works as a material proxy for the characters encased in its pages, the former's latent ontological capacity dissolving into the latter's explicit liveliness. The discussions of medieval art and artistic objects in Chapters 2 and 3 foreground the deeply interactive, intimate, and somatized nature of engaging with texts in and as manuscript forms. ${ }^{180}$ In Chapter 2 in particular, I pay attention to the way in which scholars have found themselves, and others, in their lived experience of interactive interplay with manuscripts.

This sketch of manuscript's potential to act as body raises the question of the body more generally in this book. The bodies upon which I concentrate my attention are, almost exclusively, female. I examine Jacques of Vitry, and to a lesser extent Thomas of Cantimpré, in Chapter 3. However, my examinations occur in the explicit context of dissecting the ways in which these clerics shaped their identities based on their relationships with holy women. But the women whom I study here were not the only people to strive to develop a new form of religiosity in the thirteenth century in Brabant-Liège. Barbara Newman and Anneke B. Mulder-Bakker, for instance, list twelve extant biographies of holy laymen, monks, and monastic lay brothers. ${ }^{181}$ The male counterparts to the Liégeoises are: Gerlach of Houthem (d. 1165); Bernard the Pentitent (d. 1184); Godfrey the Sacristan (of Villers) (d. c. 1200); John of Cantimpré (d. c. 1210); Arnulf of Villers (d. 1228); Simon of Aulne (d. 1229); Franco of Archennes (d. after 1230); Abundus of Huy (d. 1239); Godfrey Pachomius (d. 1262); Gobert of Aspremont (d. 1263); and Peter of Villers (d. ?). Beyond similarities in piety,

18o See in particular: Chapter 2, pp. 136-45; Chapter 3, pp. 187-92.

181 'Canon'. See also: Delle Stelle, pp. 88-92. 
there is authorial overlap between the male and female corpus. Goswin of Bossut, author of Marie of Oignies' liturgical office and Ida of Nivelles' vita, composed the biographies of Arnulf of Villers and Abundus of Huy. Alongside writing the biography of John of Cantimpré, the prolific Thomas of Cantimpré produced the vitae of Margaret of Ypres, Christina Mirabilis, Lutgard of Awyières, and the supplement to Marie of Oignies' vita.

There is a lamentable paucity of scholarship on the holy men of Liège, though in the recent past some scholars have begun to fill the gap. This scholarship, which I will briefly delineate below, bears witness to the fecundity of an intersectional, kyriarchal methodology in working with hagiographic texts. At any given time, an individual is defined by multiple categories of difference. One is never just 'woman', but also of a given social status, race, sexuality, and so on. Elisabeth Schüssler Fiorenza coins the term 'kyriarchy' to describe the 'sociocultural and religious system of dominations by intersecting multiplicative structures of oppression' which are present in all societies in historically and culturally specific iterations. ${ }^{182}$ In Fiorenza's view, patriarchy rests upon the notion that gender and sex difference is the 'primary oppression,' rendering gender the 'essential difference of humanity'. ${ }^{183}$ This suggests that patriarchy has been omnipresent and omnipotent throughout history, and continues to be the principal means of female subjugation. However, women are not only disfavoured by gender-based discrimination, but by other categories of difference too. ${ }^{184}$ Such oppressions do not act in parallel, but instead are 'multiplicative,' constantly interacting and thereby constructing 'the pyramidal hierarchical structures of ruling which affect women in different social locations differently,' the kyriarchy. ${ }^{185}$ Every individual, man or woman, is defined by various other categories of difference at any given time. If a particular identity marker is accorded a more privileged social position, it becomes 'a nodal point' through which all other markers are filtered: 'While in any particular historical moment class may be the primary modality through which one experiences gender and race, in other circumstances gender may be the privileged position through which one experiences sexuality, race, and class. ${ }^{186}$

182 'Introduction', 9. Fiorenza first elaborates the concept elsewhere: But She Said, pp. 101-32.

183 Emphasis in original. But She Said, p. 105.

184 Ibid., p. 114.

185 Emphasis in original. Ibid., p. 115.

186 Fiorenza, 'Introduction', p. 10. 
Hagiographic scholarship is dominated, by and large, by investigations that focus only on one gender or the other, male or female saints. Comparative studies are relatively rare, reflecting the tendency for scholars to pursue work in which gender is defined, more or less explicitly, as the determining 'nodal point' for saintly subjects under investigation. In these studies, patriarchy is taken as the primary oppressive category. Attention to the specific character of women's religious experience, and the ways in which patriarchy moulded and inflected that experience, is important feminist work. First begun over forty years ago, this work - as represented in the outputs of scholars such as Caroline Walker Bynum, Barbara Newman, and Anneke B. Mulder-Bakker - remains a worthy, and depressingly necessary, endeavour for the foreseeable future. Nevertheless, a kyriarchal methodology develops our heuristic toolkit, facilitating even sharper deconstruction of essentialist concepts of gender difference in terms of medieval religious expression. If we adopt holiness as the primary kyriarchal 'node' for hagiographic scholarship, we open up the scope of our enquiries to incorporate complementary interrogation of holy men and women as a collective. What emerges, then, is that patriarchal-ist methodologies may have over-estimated the essential(ist) differences between saintly men and women and their experiences. ${ }^{187}$ This is borne out by recent work on the holy men of Liège. ${ }^{188}$

Jeroen Deploige, for example, presents the anonymous biography of Simon of Aulne, a Cistercian lay brother, in dialogue with several of the Liégeoises vitae. ${ }^{189}$ This shows the interconnection of the holy men and women, and

187 On this, see in particular Biddick: pp. 136-38; Hollywood, pp. 26-56. Biddick critiques Bynum's insistence in Holy Feast that gender alone is that which defines medieval women's lives, excluding other significant factors which impact their subjective experiences. Hollywood challenges Bynum's findings in another book, Fragmentation, which evinces that the corporeal paramystical phenomena which became a common motif of twelfth- and thirteenth-century hagiography reflected a specifically female religious praxis of the body. Hollywood shows, for example, that female-authored hagiographies do not feature such graphic somatisation in the lives of holy women in the period. Both Biddick and Hollywood's criticism are founded, albeit implicitly, on a need for a kyriarchal methodology.

188 See: Deploige; More, 'Convergence'; M.G. Newman. For a kyriarchal approach to relevant gender history, see: Sautman. In this study of the reigns of two thirteenth-century countesses of Flanders, Joan (r. 1214-1244) and Margaret (r. 1244-1278), Sautman demonstrates that the 'general political context, rather than sex and gender' caused trouble in the sisters' governance (p. 49). Joan and Margaret were defined more by their status as high-ranking women of prestigious ruling lineage than the biological fact of their sex (see in particular pp. 51-53,60).

189 At present, there is no standard edition of Simon's vita. The original manuscript of Simon's 1229 vita has been lost. However, a seventeenth-century copy remains: Vita Simonis Alnensis, Brussels, BRB, MS $8965-66$, fols. $209^{\mathrm{r}}-223^{\mathrm{v}}$. Deploige notes that he is preparing an edition of this 
their supporters, in the period. Simon appears as a powerful spiritual colleague in Lutgard of Awyières' biography as the pair band together to save a nun from diabolical attack with their prayers. ${ }^{190} \mathrm{In}$ his Historia occidentalis (Occidental History) Jacques of Vitry recounts his knowledge of a certain Cistercian brother to whom God endows the knowledge of all concealed sins, plausibly an allusion to Simon. ${ }^{191}$ Simon's mystical ability to decipher any mortal's hidden sins is the hallmark of his holiness. He shares this trait and several others - including the ability to exorcise demons, reception of visions of heaven and hell, and hostility towards him from his community - with many of the Liégeoises. ${ }^{192}$

Another shared aspect of piety evident in the co-ed corpus is the reversal of gender norms as a motif. Alison More asserts that the Liégeois(e) biographies portray the fluidity of gender, with holy women taking on typically masculine ideals from which the holy men are shown to retreat. ${ }^{193}$ Holy men, for example, engage in acts of highly physical asceticism which is often characterized as feminine, or at least predominately present in hagiographies of holy women. ${ }^{194}$ Goswin of Bossut relates how Arnulf of Villers, a Cistercian lay brother of Villers, mortifies his flesh by binding his body tightly with a rope for numerous days. Eventually, the rope became 'so firmly embedded that the flesh began to rot and wriggle with worms', and his putrefying skin gave a foul odour. ${ }^{195}$ Arnulf's extreme penitence is not sanctioned by his monastic superiors, who had in fact ordered him to remove two other ropes moments before he donned this particularly tight longer cord. His gender does not protect him from the kind of criticism holy women face when attempting to push their ascetic acts to the limit. ${ }^{196}$

manuscript, though it is not yet available (p. 102, n. 34). The earliest account of Simon's piety occurs in Caesarius of Heisterbach's Dialogus miraculorum: I, 3.33.150-55. The seventeenth century witnessed a resurgence of interest in Simon, with a concomitant expansion of his corpus: his vita was rewritten in Latin, translated into French, and also transformed into an illustrated narrative. For full details, see: Deploige, pp. 101-02.

$190 V L A, 2.1 .10 .245^{-46}$; Deploige, pp. 101, 113-14. Simon is also mentioned in Odilia of Liège's biography: Vitae B. Odiliae vidua Leodiensis libri duo priores, pp. 255-57.

191 Hinnebusch (ed.), 14.115; Deploige, pp. 111-12.

192 Deploige, pp. 106, 111, 116.

193 'Convergence', in particular p. 34. On masculinized female saints, see also: Easton.

194 More, 'Convergence', p. 36 . See also n. 187 above regarding the potential pitfalls of categorizing intense somatization as a particularly female expression of piety.

195 Life of Arnulf, 1.1.10.132. 'carni ejus tam valide immersus est, ut de carne ejus putrefacta vermes ebuillerent'. De B. Arnulfo, 1.1.10.56o. On Arnulf's asceticism, see also: M.G. Newman, pp. 190-92.

196 See, for example: $V B N$, 1.4.26.30-32; VJC, 1.1.4.445. 
In contrast to feminized portrayals of holy men, holy Liégeoises are masculinized in various ways. For example, Ida of Louvain's conversion to Christ, in conflict with her parents' wishes, is characterized as '[n]either womanish nor knavish' ('non muliebriter aut ignave') but 'marked rather by bravery and manly constancy' ('sed forti virilique constantia propulsaret'). ${ }^{197}$ Moreover, Goswin of Bossut's vita of Ida of Nivelles does not contain any examples of the excessive 'feminine' self-mortification evident in Arnulf's biography. ${ }^{198}$ In many other ways, however, Ida and Arnulf's religious experiences run parallel: both work hard to save souls and rescue people from purgatory, compassionately consider Christ's Passion, and receive visions revealing the truth of the divine. Gendered imagery functions as a useful tool to showcase the saintly transformation from a life entrenched in earthly concerns towards the divine: 'a journey away from any expression of sexual identity'. ${ }^{199}$ By the end of their lives holy men and women 'become genderless saints,' though they continue to inhabit biologically gendered bodies. ${ }^{200}$

In a study of male and female Cistercian hagiogaphies produced by Villers monastery in the thirteenth century, Martha G. Newman contends that social class and literacy differentiate holy individuals more than gender. She asserts that there are three 'explicitly gendered positions' evident in the Villers corpus. ${ }^{201}$ Firstly, monks are portrayed as adopting a feminine role in relation to God, underpinned by nuptial imagery. Lay brothers are characterized in explicitly masculine terms, shown to mortify the flesh in forms of imitatio Christi. Religious women occupy a third position, in earlier texts being described with nuptial motifs similar to the monks. In later works, the women tend to be depicted in the mode of the lay brothers, with imagery of intensely corporeal asceticism and masculine virility. As Newman points out, this shift testifies the fact that 'Cistercian authors were more concerned about maintaining differences based on literacy and monastic status than about emphasizing distinctions based on sex,' at least initially. ${ }^{202}$ Illiteracy fundamentally differentiated lay brothers from monks. This difference was strictly enforced: lay brothers were forbidden from learning to read. The deficiency severely impacted lay brothers' influence within the Order, as they could not participate fully in clerical life. Lay brothers also lived apart from monks, wore a different habit, and followed

197 VILovEng, 1.1.4a.5; VILov, 1.1.4.159.

198 M.G. Newman, pp. 198-99.

199 L'Estrange and More, pp. 7-8.

200 More, 'Convergence', p. 42.

201 P. 185.

202 Ibid. 
a shortened liturgy. They were, in essence, 'second class' monks. Indeed, the lay brotherhood had been founded by the Order as a pool of agricultural labour which could work land holdings and lay brothers were often, though not always, peasants. For the monks of Villers, it was more important to discriminate between men's social status than on the basis of gender, at least for a time. It is unclear what precisely induced the shift from social status to gender as the primary kyriarchal node of differentiation in the hagiographies. ${ }^{203}$

I affirm that holiness, expressed as an extreme (divine) visual acuity, is the primary kyriarchal node through which the Liégeoises inhabit all other structural positions. However, this remains a hypothesis, given the lack of explicit comparative study of the male corpus. Nevertheless, this book is deeply inflected by a kyriarchal methodology. Whilst gender politics are acknowledged and taken account of throughout, the focus remains on the Liégeoises as holy individuals gifted with divine sight first, with their femininity a complicating secondary factor. As articulated in my elucidation of the 'agape-ic' encounter above, I privilege the holistic bodily spectatorial experience, particularly in terms of Sobchackian film theory. This is in conscious opposition to the expressly gendered spectatorial frameworks derived from Mulveyian cinematic scholarship. Within my analyses, the function of the saintly body is highlighted, a function which could well apply similarly to a masculine saintly body, albeit with an expression modulated by gender. It is for this reason that I use inclusive language whenever possible throughout this book. Whilst I preserve female pronouns for the medieval holy women under investigation, I deploy the gender-neutral singular 'they' ('them', 'themselves', 'their') for all other references to generalized readers, viewers, and so on.

\section{Overview of Chapters}

Bruno Latour elaborates a theory of the 'polytemporal' in which events are organized according to a helical, as opposed to linear, schema:

We do have a future and a past, but the future takes the form of a circle expanding in all directions and the past is not surpassed but revisited, repeated, surrounded, protected, recombined, reinterpreted and reshuffled. Elements that appear remote if we follow the spiral may turn out to 
be quite nearby if we compare loops. Conversely, elements that are quite contemporary, if we judge by the line, become quite remote if we traverse a spoke. Such temporality does not oblige us to use the labels 'archaic' or 'advanced', since every cohort of contemporary elements may bring together elements from all times. ${ }^{204}$

It is in this 'polytemporal' context that this book operates. Throughout, I eschew the 'spiral' paths in order to grasp the 'loops' which appear to intimately connect the cinematic and hagiographic in the shared co-incidence of 'agape-ic encounters'. In my analytical peregrinations, I use metaphor, analogy, and simile to blur the bounds of these 'loops' to their fullest extent, and ultimately to excavate to their fullest depth the gaps which stubbornly persist between them.

Chapters in this volume focus on different strands of modern cinema theory: the relationship of film to time and mortality, embodied spectatorship, celebrity studies, and digital environments. I argue for a spectrum of visual experiences from the medieval to modern period, a non-hierarchical and interconnected series of possible viewing positions which inform both the medieval and modern experience. ${ }^{205}$ Nevertheless, a coherent organizational structure is necessary to get to grips with the particularities of these 'polytemporal' neomedievalist encounters. The chapters thus unfold according to the trajectory of the technological development of cinema: from the nineteenth-century invention of the photographic process in Chapter 1 to twenty-first century digital media and virtual environments in Chapter 4.

Chapter 1 considers the interconnection of the visual and the temporal, specifically the ways in which photographic technologies and divine visions confuse our understanding of linear time. Saintly visionaries and photographic subjects exist in a temporal framework outside of 'normal' linear time. Still-living, long-dead and yet-to-be-born individuals populate the vision realm of medieval saints. Mere moments spent in vision-space may be felt as hours by witnesses to the visionary episode, trapped in a different timeline. A photograph records a moment in time: figuratively in the narrative implied by the picture, and literally inasmuch as it chemically fixes the rays of light reflected from the photographed object(s). Film, composed of still photographic frames run together, resuscitates such frozen tableaux, offering spectators access to an alternate temporality which runs 
alongside our own. Specific acts of looking, however, allow those enmeshed in linear time to momentarily experience this alternative temporality - be that moments in which a Christian witnesses a saint's miracles, or a cinema spectator identifies overwhelmingly with the narratives onscreen.

In Chapter 2, I explore the medieval understanding of the process of visual perception alongside the field of embodied film spectatorship. Medieval optical theories emphasized the necessity of the viewing subject to be touched, quite literally, by the viewed object in order for the transmission of an image to the eye of the beholder. To see an object, the viewer had to touch, or be touched by, the object's species, its intangible, imperfect, yet authentic representation. The species left an imprint of the object on the viewer's eye, either actively expelled by the object itself (intromission) or transmitted via an actualising beam emitted by the viewer (extromission). Recent film scholarship similarly posits a dialogic and haptic interplay between the moviegoer and the bodies onscreen. ${ }^{206}$ The sight of an onscreen body opens the spectator to becoming the body onscreen, feeling both the bodies portrayed onscreen and their offscreen body as their own. Similarly, medieval saints are shown literally to fuse with the object of their divine visions: God. This chapter interrogates how far theories of embodied spectatorship, particularly those developed by Sobchack, can be applied to medieval spiritual texts, and the limitations of such an approach.

In Chapter 3, I investigate the shaping of female saints as 'stars', focusing on the production of a palatable form of female sanctity authorised by the Church. When analysing celebrity, Richard Dyer maintains that 'we are dealing with the stars in terms of their signification, not with them as real people'. ${ }^{207}$ Similarly, the saints depicted in hagiographic texts are manufactured by their editors and hagiographers for specific ideological and sociological functions. As a case study, I dissect the textual representation of Marie of Oignies, cast as a celebrity-saint by her hagiographer Jacques of Vitry. Jacques' textual manipulation of Marie and her life allows him to promote his own anti-heretical causes and fast-track his ecclesiastical career. By casting himself as Marie's number-one fan, Jacques becomes a celebrity in his own right, with a following of his own. Thomas of Cantimpré, author of several of the Liégeoises vitae, self-identifies as one of Jacques' most ardent fans. I consider the ways in which Thomas attempts, ultimately unsuccessfully, to leverage Jacques' fame to build his own celebrity identity. Finally, I examine the ways in which another holy woman, fifteenth-century 
English mystic Margery Kempe, utilized Marie of Oignies as a role model in her bid for spiritual fame.

From Chapter 3's exploration of the construction of saintly identity by hagiographers, I move in Chapter 4 to examine a saint's self-fashioning via meditative visions. The medieval saint sees, hears, touches, and interacts with God in her mind - yet these mental experiences are figured as having meaningful corporeal consequences and significant tangible outcomes. The online environment of Second Life (SL) offers parallels of modern Christian worship to meditative medieval piety. SL is a three-dimensional online virtual environment designed to allow users to live out a simulated version of life via their avatar. The avatar is a visible version of the self whose appearance and behaviour is wholly controlled by the offline user. SL Christians attend services, pray, and participate in recognizable religious rites in the intangible ('meditative') space of the internet, and these rites significantly affect the user's offline body. SL Christians' modern worship experiences can shed light on the experiences of medieval mystics, and vice versa.

In my conclusion, I posit a new way of interpreting the Liégeoises as animated visual objects and active icons. As such, the women are not solely defined by their status as spectatorial objects but also dynamic agents who are capable of 'looking back'.

The terms 'technology' and 'technological' are used above, and throughout this book, in the context of the 'medieval identification of technology with transcendence', which gained particular currency from the twelfth century onwards. ${ }^{208}$ Cistercian and Benedictine monastics pioneered innovations, including the windmill and the mechanical clock, with an explicit acknowledgment of the spiritual value of such devices. Technological development became a crucial means to (re)capture a state of perfection that was lost after the Fall. Additionally, in the thirteenth century, a period in which millenarianism flourished, technology became 'a means of anticipating and preparing for the kingdom to come' and simultaneously 'a sure sign in and of itself that that kingdom was at hand'. ${ }^{209}$ Our contemporary 'secular' technological mode is ineluctably dependent on the religious tenor of all preceding technological innovation.

The modern attitude to technology, as Bronizlaw Szerszynski observes, is 'not really secular at all, in the sense of being independent of any particular

208 Noble, p. 53. On the religiosity of technology in the period, see in particular: ibid., pp. 9-29, 48-56, 211-17; Szerszynski, pp. 53, 67-73; White Jr, especially pp. 93-103, 235-53, pp. 320-38. 209 Noble, p. 26. 
religious or sacral beliefs. ${ }^{210}$ For example, the internet's capacity to function as a form of 'digital heaven', into which all users could upload their consciousness and live on for eternity, was repeatedly seized upon by the technology's earliest pioneers. ${ }^{211}$ In the twenty-first century, Silicon Valley's software engineers and computer programmers are 'taking over from the priests and the rabbis and the shamans', including in promising to consumer-believers the chance of immortality. ${ }^{212}$ Technology has not nullified potent religious belief. Instead, technology has become the language for expressing concerns and desires that were previously in the domain of the religious. Cinema's embedded mysticism, then, is an indicator of a considerably wider phenomenon. As Yuval Harari remarks: 'We are really witnessing the rise of technoreligion, a movement that makes all the traditional religious promises, but they promise to accomplish them not with the aim of supernatural beings living in the sky, but with the aid of technology. ${ }^{2213}$ This ever-present interconnection of technology and religion underpins this book's analyses. I turn now to examine photography's 'miraculous' genesis, and the way in which the revolutionary new technology was immediately turned to spiritual matters.

210 Pp. 23-24. See also Noble, p. 5; further remarks on this topic below, Chapter 4, pp. 194-95 and 220-21.

211 See in particular: Casey, 'Examination', pp. 197-201; Noble, pp. 158-6o; Spadaro, Cybergrace, loc. 35-48; Cybertheology, pp. 10-11; Wertheim, pp. 15-21, pp. 38-40, pp. 253-66.

212 Azeem and Harari, n.p.

213 Ibid., n.p. 



\section{$1 \quad$ Play / Pause / Rewind: Temporalities in Flux}

\section{The Miracle of Photography}

In 1839, a miracle transpired in Germany. Christ descended to earth and imprinted himself on an oak leaf. Or rather, it seemed like he did. In fact, the apparently mystical image was the work of Johann Carl Enslen (d.1840), a pioneer in the field of photography. 'Face of Christ Superimposed On An Oak Leaf' (Fig. 5) is the first recorded example of photo-montage, the superimposition of one image over another to create a hybrid representation. ${ }^{1}$ To produce the image, Enslen utilized the new technology of camera-less 'photogenic drawing', invented by English scientist William Henry Fox Talbot (d. 1877) in $1835 .^{2}$ After immersion in a weak salt solution and silver nitrate, a piece of paper would darken in proportion to the amount of light it received. By placing an object on top of the chemically primed sheet, a photographer could thus generate the object's negative image. Exposing this negative to another primed sheet would produce a positive image of the object.

Despite being the result of an intensive technical process - most certainly the work of man - I maintain that Enslen's image is a 'miracle'. In this, I draw upon the full weight of the etymology of the term 'miracle'. 'Miracle' descends from the Latin word 'miraculum', a nominal form of the verb 'mirare', 'to wonder (at)'. In the formulation of a late nineteenth-century etymological dictionary, a 'miracle' is 'anything wonderful: a prodigy; anything beyond human power, and deviating from the common action of the laws of nature; a supernatural event.' 'Mirare' is also the root of the term 'mirror', that reflective surface which offers the viewer an objective representation. The 'Face of Christ' encapsulates these two meanings. On the one hand, it purports to objectivity as a scientific fixing of the light rays reflected by the oak leaf. It is a 'mirror' of reality. Simultaneously, the image is literally 'miraculous' - a mystical artefact that shows God's presence in the world, a theophany. But it is also 'miraculous' precisely because it tends to a completely faithful representation of an object, to which it retains a

1 On this image, see in particular: Beaumont; Bernasconi, p. 15; Nickel, pp. 138-39; Perez, 'Picturing', pp. 162-64. For a visual history of photographs of Christ, see: Perez, Revelation.

2 Kennel, Waggoner, and Carver-Kubik, p. 61.

3 Donald (ed.), p. 323 
Figure 5 'Face of Christ Superimposed on an Oak Leaf', photogenic drawing by Johann Carl Enslen (1839)

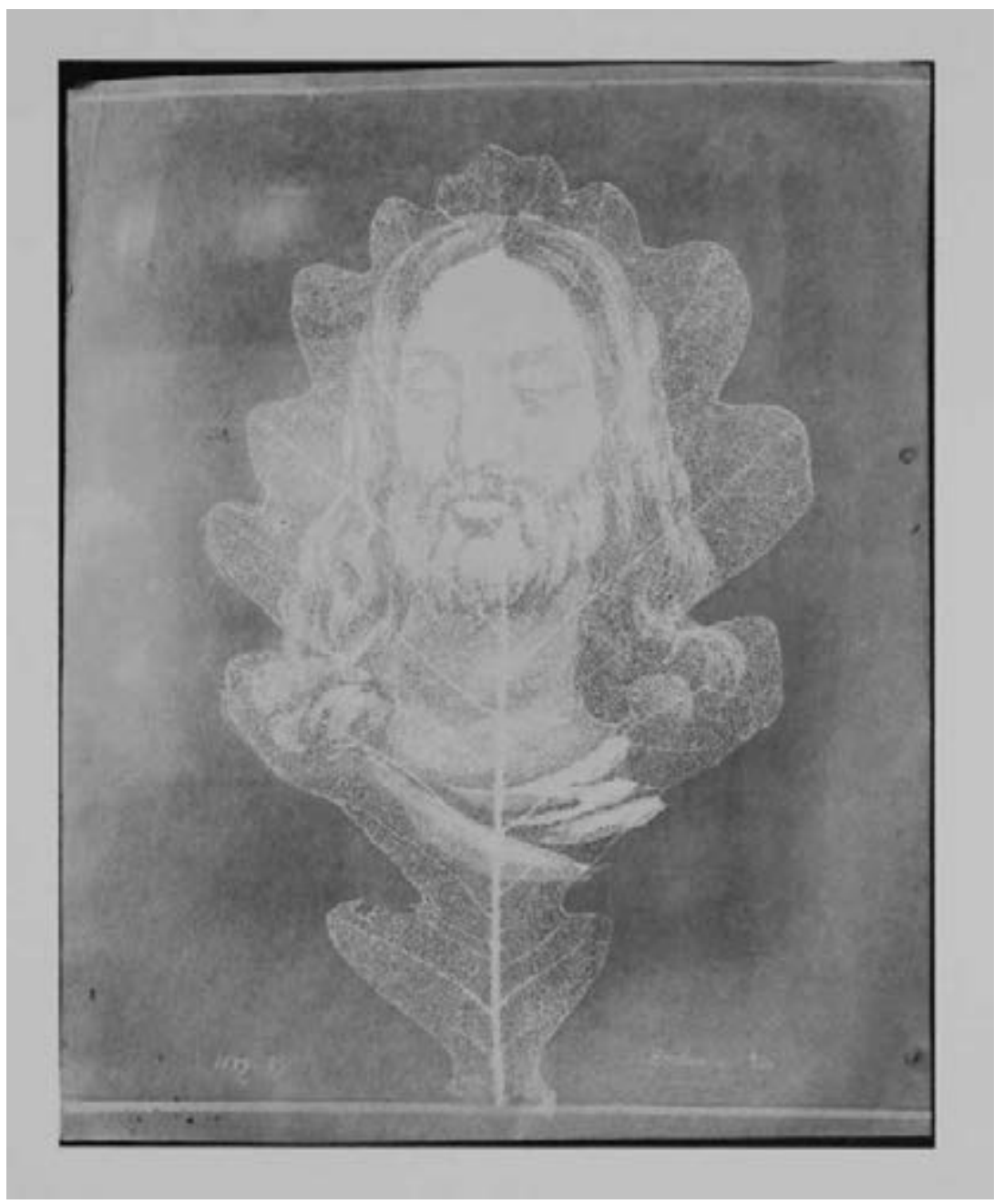

@ Royal Photographic Society/National Media Museum/Science \& Society Picture Library

direct ontological connection. Photographic technology possesses a visual power far beyond that of standard human perception, with our straining and fallible mortal eyes. It is plausible, then, that a photograph could reveal heretofore invisible presences in the world.

It is clear that Talbot also appreciated the 'miraculous' capacity of his new invention. In January 1839, he delivered a talk outlining the process 
at the Royal Society in London. He situated his discovery as 'new proof of the value of the inductive methods of modern science'. ${ }^{4}$ However, Talbot also sketched the metaphysical resonance of his photographic system: 'The phenomenon which I have now briefly mentioned appears to me to partake of the character of the marvellous, almost as much as any fact which physical investigation has yet brought to our knowledge.' Photogenic drawing, he proclaimed, was a form of 'natural magic', by which even the 'most transitory of things' is 'fixed for ever in the position which it seemed only destined for a single instant to occupy.'

The 'miraculous' values of photography were central to the massive popularity of spirit photography in the nineteenth and early twentieth century. ${ }^{5}$ Photography was hailed as an 'apparitional technology', allowing spirits and mystical forces to be made visible. ${ }^{6}$ A photograph might, for example, capture the visitation of a loved one's spirit, offering comfort to those in mourning by allowing for a form of contact with the deceased, whilst making plain the authenticity of belief in the afterlife. In March 1861, William H. Mumler took a photograph of himself alone. When he developed the image, however, a ghostly figure shared the frame with him. The spectre was interpreted as the spirit of a deceased individual, perhaps even the photographer's dead cousin returning for a familial visit. ${ }^{7}$ Mumler's haunted image was the first example of spirit photography. Writing his memoirs some years later, he stressed his sense of personal responsibility to provide testimony as to the reality of the Christian afterlife: 'I feel it is incumbent upon me to contribute what evidences of a future existence I may have obtained in my fourteen years' experience with Spirit-Photography'.

The tradition of spirit photography lives on in the twenty-first century in the form of tribute photography. ${ }^{9}$ Images of dead relatives are Photoshopped into new images of the living, often into a tableau which takes place in front of the deceased's grave. The spectrality of the scene may be amped up even further by various visual effects applied to the deceased's image. Such effects include, for example: the addition of a radiant halo, a full-body glow, a black-and-white tint, and/or a transparent opacity to the deceased's

4 Talbot, p. 25; emphases in original. Cited in Nickel, p. 133.

5 On spirit photography, see in particular: Gunning, 'Phantom Images'; Kaplan; Wojcik.

6 Wojcik, p. 111. This belief, though certainly no longer mainstream, is shared by some modern artist-photographers who produce religiously inflected images: Verrips, p. 209.

7 Kaplan, p. 19.

8 Mumler, p. 3. Cited in Kaplan, pp. 19-20.

9 See also modern paranormal photography, which purportedly documents otherwise invisible supernatural phenomena: Kripal and Strieber, pp. 29-31 
body. A nimbus-adorned heavenly stairway is another typical feature. The deceased's figure is Photoshopped atop the stairway, signifying not only that they live on in heaven, but that they are watching over their living family members. Sunny Jo, a specialist in tribute photography, explains the ethos for the name of his bundle of ghostly photographic services, introduced due to popular demand: "I will be naming it "One More Time". The reason behind the name is because this service lets you be reunited with your loved ones for one more time! $!^{10}$ The rationale for twenty-first century tribute photography is near-identical to nineteenth-century spirit photography.

As far as Mumler is concerned, photography offers irrefutable proof of divinity. For modern-day tribute photography, the images testify as to the eternal, unbreakable bond between loved ones. All are aware that the deceased has been Photoshopped into the photograph, and thus it is avowedly artificial. This artificiality does not, however, undercut the potential of the photograph to visualize the presence of the deceased. In particular, the tribute photograph indexes the love that the still living have for their deceased relatives. It is this affective impulse that has stimulated the production of the photograph, after all. Photography's capacity to exteriorize that which governs all humanity (divinity) gives way here to a more limited, individualistic appreciation for photography to make visible that which lies inside a grieving individual's heart. This reflects a shift from a religious to a secular-capitalist society.

In actuality, photography can only make a claim to truth. ${ }^{11}$ All photographs contain bias and reflect the choices and aptitudes of the photographer, not to mention the individual that commissioned the photograph. In the case of tribute photography, this was sensationally brought to light by the manner in which the medium added an extra layer of the macabre to an already gruesome crime case. ${ }^{12}$ At the behest of a grieving mother, Jeanie Ditty, Sunny Jo produced a suite of tribute photographs featuring Ditty and her deceased two-year old daughter, Macy Grace. The set of photographs bears all the hallmarks of archetypical tribute images: set in the cemetery in which Macy Grace is buried, the little girl is portrayed as a semi-transparent, glowing figure. Ditty and her boyfriend Zachary Keefer were later charged with child abuse and homicide for killing Macy Grace. Despite any appearance to the contrary, the tribute photographs did not

10 N.p.

11 On this, see in particular: Gunning, 'Point'; Newhall, pp. 86-87.

12 All detail of this case comes from Petchesky. This source also features the tribute photographs in question. 
testify to the mother's grief and love for her daughter. Instead, they were a means to obfuscate the truth, as elucidated by Sunny Jo's shocked reaction to the situation: "I find out that she wanted these photos just to lie to the public, to cover up what she did so she can look like the grieving mother."'13

The 'truth claim' that underpins photography's ability to produce proof of the divine and the invisible finds its parallel in the genre of medieval hagiography. ${ }^{14}$ Establishing this parallel reveals the way in which the epistemological postulation inherent to both forms of visual(ization) technology depend, ultimately, upon the viewer's faith. We have faith in photography's power not just to document, but to conserve, things as they were authentically in the world. This remains crucial in our comprehension of the photographic mode even when we are confronted with the fact that a photograph has been overtly, transparently 'tampered with', i.e. altered with Photoshop or similar technology. Just because a photograph has been doctored does not mean it's an outright fake. It still shows something real, though that 'real thing' may have little to do with the original scopic object and more to do with how that object was 'handled' in the editing process. The Photoshopped photograph, then, bears traces of the invisible hand of a Photoshop god, who remade an 'authentic' image of an earthly object into whatever form they preferred. To perceive the trace of the real which still inheres in the altered photograph, we need to widen the focus of our gaze: zoom out from the visual frame as it is offered to us, to apprehend instead the photograph in its produced totality. The point is less about what the photograph shows (i.e. historical fact), but what it does (i.e. authentically preserve a real trace). The same logic structures hagiography.

Hagiography is not historical per se, or rather hagiographical tales are rarely, if ever, demonstrably historically accurate. Rather, the saint's biography is an elaborate authorial construction, targeted more or less explicitly at inspiring readers to greater faith with an educative, exemplary, and entertaining narrative. But the traces of divinity that the vita conveys are real, in the same way that the Photoshopped image retains the traces of its creator. What's more, hagiography's potency to transform individual Christians' lives is authentic, if only believers open themselves up to the inspiration proferred in the text. All this is possible through faith. In his prologue to Christina Mirabilis' biography, Thomas of Cantimpré underscores the veracity of his tale. His remarks are typical of the hagiographical convention of proclaiming the authenticity of saintly deeds. Thomas has 
gathered first-hand accounts from witnesses to the holy woman's spiritual works, including incorporating the observations made by his venerable mentor Jacques of Vitry in his vita of Marie of Oignies. ${ }^{15}$ Thomas, he assures us, is entirely certain of the events that he presents to us. Yet, Christina's life is full of strange occurrences, including the protagonist's three deaths. In anticipation of readers' unwillingness to believe the truth of the vita, Thomas declares: 'I admit - and it is true - that my account surpasses all human understanding, inasmuch as these things could by no means have occurred according to the course of nature, yet they are possible to the Creator. ${ }^{16}$ The vita is miraculous in the same way as Enslen's photo-montage: it 'objectively' reveals a genuine presence of the divine. As the spiritual imaging capacity of photography exceeds 'natural' human vision, God makes visible His presence in the world by 'imaging' himself in the words, deeds, and body of the saint.

Before I embark upon further analyses, a note on terminology is necessary. The term 'photograph' is not monolithic. There is no overarching unity of apparatus, medium, or format which contributes to a label of a given image as 'photographic'. For example, Talbot's photogenic drawing technique, an instant Polaroid, and a digital camera all operate in decisively different ways. Nevertheless, all three generate 'photographs'. Photography, then, is best defined in terms of functionality, and in the theoretical claims underpinning the image's production and reception. Throughout my arguments, I use the terms 'photograph' and 'photographic' to refer to images which evince the 'photographic function'. For the purposes of this chapter, the 'photographic function' primarily comprises:1) the apparent objectivity and authenticity of the image; 2) the ontological connection between the image and its object (the index); 3) the confusion of temporality implicit in the image and its reception. ${ }^{17}$ As becomes apparent below, the latter criterion is ultimately generated by the first two, and it is to an interrogation of this temporal ambiguity that I devote this chapter.

$15 V C M$, prol. 1-3.65o. For claims similar to Thomas's, see: VBN, prol. 4-6.2-7; VES, 2.362; VIH, prol. 7.865; VILéau prol. 3.08; VILov, prol.157; VINApp, prol. 222-23; VJC, prol. 444; VLA, prol. 234; $V M O$, prol. 111.636-38; VMY, prol. 106-07. For Jacques' testimony about Christina, see: $V M O$, prol. 8.638. For Thomas' proclamation of the educative value of the vita, see $V C M, 5.55 .659$.

16 VCMEng, prol. 3.128. 'Fatemur quidem, \& verum est, narrationem nostram omnem hominis intellectum excedere, utpote quæ secundum cursum naturæ fieri nequaquam possent, cum tamen sint possibilia Creatori'. VCM, prol. 3.650.

17 There has been much debate as to the perceived non-indexicality of digital photography, which severs the material connection to the photographed object as it eschews chemical processes. I consider both digital and traditional photography to be indexical, though this indexicality is achieved via different means. On this, see: Gunning, 'Point'; Marks, Touch, pp. 161-75. 


\section{Photographic and Sacred Time}

The photograph operates as both a 'landscape' of and 'windowpane' into time. ${ }^{18}$ The 'landscape' proffered by the photograph is the static tableau of a moment taken out of the march of linear time. Laura Mulvey maintains that ' $[t]$ he index, fixed as it is in the photograph, is a record of a fraction of time. When rays of light record an object's presence they also inscribe that moment of time, henceforth suspended. ${ }^{\prime 19}$ The photograph records the temporal frame of that which it images, thereby offering us a 'windowpane' through which we can penetrate - if only meditatively - the specific time that the photograph purports to ossify. The photograph is an image 'that is static but that nonetheless can give a powerful sensation of time passing. ${ }^{20}$ The timeframe conjured by the photograph is non-chronological. The fixed 'present' of the photograph is superimposed on the contemporary moment in which we view it. Past and present flow into one another: with our gaze, we thaw out the moment in time that the photograph has 'frozen'. As such, the discrete temporal descriptors of 'past' and 'present' become unintelligible. We experience a sense of timelessness. As Damian Sutton argues, "timeless"' does not necessarily signify "durationless". ${ }^{21}$ Rather, the temporal schema that governs the photograph's reception is that of 'pure duration', the collapse of the temporal partitions of past, present, and future which orient our lives. Nevertheless, the photograph's capability to disrupt linear time is dependent on the chronology that it distorts. If the photographer had not captured the image in the past, then it would be impossible for the viewer to access the photograph in the present.

The photograph encapsulates two temporalities: the chronological and the a-temporal. Medieval time is structured according to two intersecting temporal modes which functionally correspond to those of the photograph. Human life unfurls according to the linear schema of earthly time, from birth to death. Yet, death is not the end. After passing from the mortal realm, an individual enters the eternity of sacred time, of divinity itself. Within this framework, holy women are privy to the divine photograph that instantiates an alternate temporality within and alongside the viewer's (mortal) chronology. Saints access sacred time in their spiritual visions, in which they routinely see and interact with the living, the dead, and individuals 
from the Bible. Margaret of Ypres, for example, receives visitations from St. Catherine, Mary Magdalene, the Virgin Mary, and Christ. ${ }^{22}$ By tapping into the perpetual simultaneity of sacred time, Margaret also perceives her confessor, Zeger of Lille, in the present moment - even though he is some five leagues away from her. ${ }^{23}$

Knowledge gained from rapturous visions allows the holy women to puncture the 'ordinary chronology' of the mortal world. ${ }^{24}$ During ravishment, for example, Ida of Nivelles sees 'among things past what is no longer; among things future what is not yet; among things present what is afar. ${ }^{25}$ In the a-temporal plenitude of the divine embrace, the typical tripartite division of time is meaningless. Instead, all events from all times come into focus. Ida utilizes insight garnered from her prophetic visions to interrupt and re-organize the chronology of the mortal world. For instance, after mystically intuiting a young man's former career as a monk, she urges him to repent his apostasy and return to his monastery. ${ }^{26}$ Juliana of MontCornillon's anonymous biographer characterizes prophecy as the unveiling of a given event's location in eternity:

Prophecy includes past, present, and future times. Since the meanings of the word can refer to these three times, then, prophecy is rightly so called not because it tells the future, but rather because it reveals the hidden. ${ }^{27}$

The markers 'past', 'present', and 'future' occlude the divine reality of time as eternity. As with Ida of Nivelles, Juliana's immense powers of prophecy lie in her capacity to see beyond such occlusions and appreciate the truth of the matter, to consider the divine photograph and its evocation of perpetual present-ness.

As much as mortal time leads to sacred time (the eternity of the hereafter), it is also part of sacred time. Thus, medieval Catholics live in a 'strained,

\footnotetext{
22 VMY, 11.111; 24.118-19; 31.121; 35.123; 37.123-24; 39.124.

23 Ibid., 34.122-23.

24 Le Goff, Sacred Time, p. 163. On this and time more generally in the Middle Ages, see in particular : ibid., pp. 22-32; Gurevich, Categories, pp. 25-44, pp. 93-153; 'Medieval Chronotope', pp. 229-34; Popular Culture, pp. 136-40; Scribner, pp. 56-58

25 VINEng, 30i.85. '[...] videre de præteritis quod iam non est; videre de futurus quod nondum est; videre de præsentibius quod absens est.' VIN 30.280.

26 VIN, 15.237-39.

27 VJCEng, 1.5.21.20. '... præterirum, præsens, \& futurum tempus continet prophetia. Ut igitur expositio hujus nominis prophetia, tribus his temporibus valeat convenire; recte dicitur prophetia, non quia prædicit futura, sed quia prodit occulta.' VJC, 1.5.21.
} 
dislocated, time-scheme. ${ }^{28}$ The Incarnation augurs humanity's salvation, thereby situating an anticipated future in the past. However, this salvation is deferred, and will only occur at the time of Christ's Second Coming, at some unknown point yet to come. From this perspective, the medieval Catholic's existence is implicitly anachronistic, situated 'both before the end, and after it'. Sutton defines the time evoked by the photograph as 'the traumatizing nonchronological time, which shatters the temporal flow of space-time and projects "the immensity of past and future" out into the time of the look, the out of field. ${ }^{29}$ From this perspective, the Incarnation evinces a photographic effect on mortal time. It is traumatic specifically because it brings the end of time into the believer's present moment. The photograph both anticipates and forestalls the 'end' (disappearance) of its object, and thus can be understood as a secular Incarnation. Whilst the stasis wrought by the photograph is 'a death in replica', it also conserves the object in a state of perpetual present-ness. ${ }^{30}$ 'Salvation' (preservation of the image) was guaranteed at the moment the photographer took the picture. Yet, the memorial promise of the photograph is only fully realized when the image is seen, when we have evidence of its existence. In place of Christ's Second Coming, then, it is the photograph's 'Second Looking' that ultimately offers a glimpse of eternity. What's more, this 'Second Looking' allows for viewers to stabilize the chronology of their own history. Writing in 2013, theatre director Katie Mitchell sums up the reason she feels that looking at old family photographs is so important: 'Like many people, my family was broken up by time, events, place and so on, and looking at these is a way of putting the pieces of my past together, like a jigsaw. ${ }^{31}$ In much the same way, Christ's Second Coming will finally impose an end-point on mortal time from which we can extrapolate a stable linear ordering of the past which believers then impose retroactively.

\section{Saints as Photographs}

During ecstasties, holy women perceive and merge with sacred time, viewing the photograph of divinity. Their bodies, however, remain on earth time, 'paused' in a coma-like stasis much like that of the photograph itself. ${ }^{32}$ Ida

28 Markus, p. 24.

29 P. 56. He cites from Deleuze, p. 32.

30 Stewart, p. $15^{2}$.

31 Morrison et al., n.p.

32 See: $V B N, 1.11 .55-56.68-70 ; 2.17 .163 .190-92 ; 2.19 .180 .208 ; 3.2 .194 .226 ; 3.4 .203 .234 ; 3.5 .206 .238$; VCM, 3.36.656; VES, 3.363-64; 5-6.365-67; VILov, 1.5.34.167; 2.6.32.179-80; 3.1.9.184; 3.2.13.185; VIN, 
of Léau, for example, routinely appears 'like someone dead' ('vertensque tamquam mortuam') during her ecstasies. ${ }^{33}$ In a typical incident, the holy woman falls into rapture after ingesting the Eucharist. Another nun's attempts to move Ida from her prone position on the church floor are futile. Ida 'had ceased to function and simply lingered there, an unwieldy hunk, devoid even of the breath of life'.$^{34}$ Rapture transforms Ida into a spectacular and specular object for others' ocular consumption. Although the nun cannot shift the holy woman, she remains in the church so that she can gaze upon Ida's face at her leisure. Ida's face radiates the grace of God which she is experiencing so intensely in ecstasy. The nun receives a second-degree glimpse of the divine, by looking at a photograph (Ida) of another photograph (God). Ida's stasis represents her complete immersion in sacred time, which renders her participation in the linear flow of mortal time impossible.

'[B] ecoming visible' - photographed - is central to the transformation of a run-of-the mill individual into an authentic saint.$^{35}$ In order to be recognized as a saint, a woman must earn the collective approbation of her community, providing evidence of her holiness through visible signs. The photograph indexes that which it images, chemically fixing or digitally recording the rays of light reflected from the photographed object(s). The 'photographic' saint also operates indexically, manifesting God's real presence in the world. Though she is not identical to God, His presence is an integral part of her life and her body. Beatrice of Nazareth's biographer describes this process in terms of an impression. During rapture, the Lord 'pressed [imprimeret] her soul wholly to himself in the sweetest embrace; and just as soft wax, pressed with a seal [impressa], displays the seal's character in itself, so the divine Spirit modeled her soul according to his own image, and conformed it very appropriately to his own likeness with some proportional harmony. ${ }^{36}$ The metaphor of impression is re-iterated in the vita of Ida of Louvain to convey

20.250; 23.256-57; 29.274-76; 30.281; VJC, 1.5.28.453-54; VMY, 19.116; 21.117; 40.124; VMOSupp, $3.14 .672 ; V M O, 2.7 .65 .654 ; 2.9 .81 .658 ; 2.10 .87 .659 ; 2.12 .107 .665 ; V I H, 22.66 .876$. See also striking episodes of ecstatic stasis in the life of the French beguine Douceline of Digne (1215-1274): Philippine of Porcellet, 9.174.70-124. For further references to ecstatic stasis, see below: p. 131, p. 246, p. 250. 33 VILéauEng, 31b.32; VILéau, 4.31.117. For similar incidents, see: ibid. 3.2425.11415; 4.36.118; 5.4647.121.

34 VILéauEng, 47.50. '[...] permanens quasi vacua omnia vitali spiritu, et tamquam moles corporis inutilis et inepta, a luctante pro nihilo nequivit aliquatenus removeri.' VILéau 5.47.121.

35 Cazelles, Lady, p. 44.

$36 V B N, 2.18 .166 .194-97$. '[...] illius animam, amplexu suauissimo, sibimetipsi totam imprimeret:, et sicut, impressa sigillo mollis cere materies, illius in se karacterem representat, sic ad ymaginem suam illam effigiatem, diuinis spiritus redderet: , et, ad similitudinem suam decentissime figuratam, quadam sibi <proportionali> confromaret consonancia.' See also 
the distinctly physical effects of such intimate liaisons with God. The Lord 'impressed upon' ('impressit') Ida the torments of His own wounds in the form of mystical stigmata. ${ }^{37}$ Her lacerations transform her into a spectacle, an object defined by the necessity of a viewer to gaze upon it. At the close of Beatrice of Nazareth's vita, the author urges his readers to 'firmly imprint [imprimatis] on your minds and inscribe on the fleshy tablets of your heart the imitable image of [Beatrice's] life'.$^{38}$ As the Lord impressed his presence into Beatrice's being, readers should incorporate the holy woman's image (presence) into their own lives. The reader should become a 'photograph' of a 'photograph', conserving a trace of the trace present in the original indexical object. As a 'photographed photograph', the reader has a less direct relationship to the index (God), but is nevertheless haunted by some vestige of His presence that was captured in the first photograph.

Roland Barthes maintains that some photographs have the capacity to 'wound' the viewer, to implicate the viewer directly in their epistemology. ${ }^{39}$ Such photographs possess the 'punctum', a 'kind of subtle beyond' the image itself, a tendency towards 'the absolute excellence of a being, body and soul together'. ${ }^{\circ}$ The 'punctum's' tendency to wound is expressed literally in Ida's stigmata. Her wounds index that original wound - God's sacrifice of His only son, a being in whom flesh and spirit cohered perfectly. By looking at Ida's stigmata, individuals are 'wounded' afresh by the 'punctum' of Christ's Passion: 'They served as a living and indisputable reminder of his Passion, not confined to mental imagining but visible to the naked eye! ${ }^{14}$ The 'punctum' unleashes a cascade of responses in the photograph's viewer: 'I see, I feel, hence I notice, I observe, and I think'. ${ }^{22}$ Equally, Ida's stigmata provoke a progression from sight to contemplation and comprehension to those who look at her. Her body is not breaking down due to illness or lack of care. Instead, it bears the marks of Christ's suffering, thereby graphically asserting God's authenticity and the guarantee of humanity's eventual salvation.

Elisabeth of Spalbeek's stigmata: VES, 3.363-64; 13.371. Alice of Schaerbeek's leprosy can also be understood as a form of perpetual stigmata: Spencer-Hall, 'Suppurating Wounds'.

37 VILov, 1.3.13-17.162-63. Citations from: 1.3.13.162; VILovEng, 1.6.13a.14.

$38 V B N, 3.17 \cdot 342-43$. '[...] quatenus imitabilem sue conuersationis ymaginem, [...], sic vestri mentibus imprimatis et in tabulis cordis carnalibus tam firmiter inscribatis [...].'

39 P. 21.

40 Ibid., p. 59. Emphases in original.

41 VILovEng, 1.6.14a.14. '[...] passionisque Dominæ memoriale redivivum \& indubitatum de se præbentia monumentum, non jam imaginariis aut mentalibus considerationum aspectibus intueri, sed corporalibus in palam oclis speculari?' VILov, 1.3.14.162.

42 Barthes, p. 21. 
The process of 'becoming visible' as a photograph entails an objectification of the holy woman for the ocular consumption of others. ${ }^{43}$ The woman's subjectivity is a hypothetical and ever malleable addendum that each viewer reads - or rather looks - into her imaged form, according to their specific interests. In her ecstatic photographic form, for example, Ida of Léau becomes an object to be traded in the spiritual economy of her community. ${ }^{44}$ In one interlude, she is sought out by a cleric for the sole purpose of being the object of his gaze when she is in rapture. The cleric offers Ida's companion the recitation of two Psalters of Our Lady if she will lift the ecstatic holy woman's veil and permit him to study her face. Nevertheless, raptures also offer holy women intimate experiences of the divine, without recourse to traditional routes offered by the clergy. This tension between the personal relationship with God found in raptures and the mediated experience offered by the Church is also highlighted in Ida of Léau's vita. Due to Ida's tendency to experience ecstatic stupors when exposed to the Eucharist, the nuns of La Ramée prohibit her from taking Communion at all. ${ }^{45} \mathrm{Her}$ behaviour is interpreted as overly disruptive of Church services, particularly in light of Ida's habit of forgetting to drink from the sacristan's cup. Ida is but one of 'quite a number' ('quamplurimæ') of nuns that fail to return from the altar in an 'orderly fashion' ('non redirent ordinate de altari'), and thus a whole host of women are penalized by the new edict. ${ }^{46}$ The direct rapport with divinity cultivated by Ida and the other Liégeoises is a more widespread phenomenon, and a significant destabilizing force for the Church which faces reduced control over such believers' worship praxes. What's more, Ida's vita offers a fairly bleak portrayal of the Church's capacity to (re)assert authority over such 'wayward' Christians. The nuns of La Ramée's plan to domesticate Ida's spirituality backfires, driving her ever more intimately into the arms of Christ. Banned from taking Communion by her sisters, Ida turns directly to Christ and pours out her prayers. In response, the Lord visits her each Sunday for a year and administers the sacraments directly. The interlude starkly demonstrates the problems inherent in any Church attempt to impose external strictures to govern holy women's spiritual behaviours. Attempts to limit private devotional encounters can, and often do, lead directly to an intensification of the 'special bond' between holy woman and God.

Ibid; VILéauEng, 19b.2o. On this episode, see also above: p. 34. 


\section{Pressing Play: Cinematic Reanimation(s)}

The saint becomes a 'photograph' during ravishment; the divine photographer has hit the pause button on time itself. What happens if we press play? In a word: cinema. In André Bazin's famous words, photography - alongside painting and sculpture - is 'the practice of embalming the dead' ('la pratique de l'embaumement'). ${ }^{47} \mathrm{~A}$ 'mummy complex' (“'complexe" de la momie') compels such representational processes, a need to snatch artificially an object from time's flow and store it in a form of perpetual life ('l'arrimer à la vie'). If Bazin's 'mummy complex' fundamentally structures photography, a parallel impulse, a 'zombie complex', underpins cinematic processes and functions. Photograms are the elemental components of the filmstrip, 'individuated photographic units', which are spliced together and run through a projector to generate the illusion of movement on the movie screen. ${ }^{8}$ On a functional level, the inanimate photograms 'come alive' by projection, sutured together to create the illusion of a time experience..$^{49} \mathrm{As}$ film resuscitates the frozen tableaux of photography, Bazin's mummy shambles to life.

Cinema and photography are both 'technologies of temporal dislocation', different only by degree..$^{\circ}$ Film leverages the process of temporal mummification central to the photographic function and takes it one step further. Indeed, the potential of film to 'zombify' the individuals captured in its photograms was central to the appeal of the medium in the late nineteenth century, a culture 'obsessed with death' that enthusiastically embraced spirit photography for similar reasons. ${ }^{51}$ Press reports of the first public showcase of the Lumière brothers' new motion-picture projector in Paris in 1895 seized upon the technology's miraculous capacity to trump death..$^{2}$ With the new-found ability to record the bodily movements of loved-ones, a journalist for La Poste argued that 'death will cease to be absolute' ('la mort cessera d'être absolue') ${ }^{53} \mathrm{~A}$ colleague in Le Radical breathlessly concurred: 'now we can collect and reproduce life' ('on receuille maintenant et l'on reproduit la vie'), ultimately allowing us to bring back our deceased nearest and dearest at will.

51 Christie, p. 8.

$5^{2}$ Burch, pp. 20-21; Christie, pp. 9-10; Ma, p. 100; Stewart, p. x.

53 Translations by Richard Abel, in Christie, p. 8. Original text cited in: ibid., p. 11, n. 31, from Le Radical, 30 December 1895 and La Poste, 30 December 1895. 
The trajectory from mummy to zombie - photograph to moving image - and its attendant temporal complexities is played out dramatically in the vita of Christina Mirabilis, the so-called 'zombie' saint. ${ }^{54}$ In 1182, Christina, heretofore a humble cow-herd in Sint-Truiden, contracts a mysterious illness and dies. ${ }^{55}$ Her 'lifeless body' ('corpus exanime') - evocative of the radically still photograph - is transferred to church in anticipation of burial. Miraculously, Christina is reanimated, and ascends to the building's rafters. Her body is only partially mobile, in a manner reminiscent of the staccato movement of images produced by a projector stuttering to life. She is 'immovable' ('immobilis') until a priest tempts her down from her lofty perch with the sacraments. Catholic rites speed up the 'projection' of Christina's body-image, and allow her to assume the fluidity of normal mortal movement. Christ himself is the 'projector' in this scenario: Christina has been returned to the living in order to experience the torments of purgatory on earth by divine will. ${ }^{6}$ Her post-mortem body will be able to withstand such suffering miraculously, and she will remain seemingly unharmed by the multitudinous punishments to come.

Cinema, Garrett Stewart argues, is an 'immortality machine'. ${ }^{57}$ Christianity is an earlier 'immortality machine', ensuring with its doctrines that its devotees enjoy life eternal. Resurrection is at the very heart of Christian doctrine: the greatest example of the authenticity of revivification is Christ's rise from the dead. $5^{8}$ All Christians, sinners included, will eventually regain an immortal body via resurrection after death. However, there was - and is - debate as to when exactly the soul reclaims the body. The liturgy emphasized the concept of a first resurrection espoused in Revelations 20.6 during the early Middle Ages. ${ }^{59}$ The first resurrection involves only the resurrection of the righteous. After a millennium, all, including sinners, will

54 B. Newman, 'Devout Women', p. 5o. I discuss Christina's zombie-ism and relevant modern theories of zombieology in detail in: Spencer-Hall, 'Horror'. Various other saints reportedly experienced mystical reanimation, with at least six other examples from the thirteenth and fourteenth centuries alone: Peter Amengol (d. 1304), Agnes of Montepulciano (d. 1317), Margaret of Castello (d. 1320), Catherine of Siena (d. 1380), and Julian of Norwich (d. c.1416). On this, see: Petroff, Visionary Literature, pp. 40-41; Quigley, pp. 192-93. Other holy women in the corpus are also shown to return from the dead, though less vividly than Christina: VILov, 2.5.26.178; VMOSupp, 3.14.672.

55 VCMEng, 5.130; VCM, 1.5.651.

$5^{6} V C M, 1.6-8.65^{1-} 5^{2}$. Cf. discussion of Christina's resurrections in terms of the modern technol-

ogy of holographic projection in: Spencer-Hall, 'Post-Mortem Projections'.

57 P. 320.

$5^{8}$ See John 5. 28-29; 6. 39-40; 11. 25; Luke 14.14.

59 Le Goff, Purgatory, pp. 123-24. 
be resurrected for the Lord's final judgement. After divine judgement, the pious will be released to heaven, whilst the sinful will be remanded to hell. Saints will inhabit a glorified body, as described in 1 Corinthians 15·35-44.

Unlike the holy women discussed above, Christina does not experience any 'photographic' mystical raptures before her death. Indeed, Thomas of Cantimpré begins Christina's vita with this event: her life-story unspools from her death. Although the holy woman was blessed with spiritual gifts, these were entirely hidden from those around her.$^{60}$ Further, her family organize their household according to the tripartite division of labour found in monastic institutions: nuns, lay sisters, and farm labourers. ${ }^{61}$ Christina's two sisters are assigned the explicitly spiritual roles of prayer (nuns) and housework (lay sisters). She is relegated to the latter, least spectacularly religious, category. Barthes' concept of the 'punctum' characterizes the experience of 'photographic' ravishments. By contrast, Christina's pre-death existence equates to Barthes' 'studium', an intellectual appreciation for the intended meaning of an image which is devoid of the 'punctum's' ability to wound the viewer. ${ }^{62}$ The 'studium' is 'always coded', deciphered and intellectualized via the knowledge of cultural contexts. ${ }^{63}$ Christina's pre-mortem spirituality is similarly 'coded', intelligible within the framework of monastic structures but offering no spectacular frisson of religiosity to the viewer. It is only by becoming a 'moving image' - an animated corpse - that Christina can evoke a form of 'punctum', that her brand of religious excellence can be appreciated, and deeply felt, by her community. This 'punctum' is further intensified in Christina's case, as she returns to life after three separate 'deaths. ${ }^{64}$

\section{Execution Films}

The existential thrill (or 'punctum') of witnessing a death on film, made reversible by the cinematic medium itself, captivated the audiences of early cinema. Execution films, a subgenre of actuality films, were widely popular works. ${ }^{6}$ Actualities, documentary pieces which showed 'real life' events both newsworthy and banal, were the preferred genre of early cinema, with audience tastes only switching to more narrative works at some point

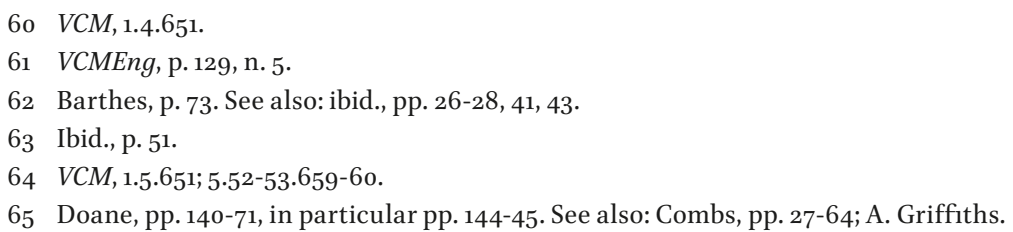


between 1902-1903 and 1907. Vivian Carol Sobchack argues that film is charged with 'existential and ethical investment' if an irreversible death is witnessed onscreen. ${ }^{66}$ Such filmic events, she maintains, generate in the audience 'a sense of the world, existence, bodily mortification and mortality, and all the rest of the real that is in excess of fiction. ${ }^{67}$ Similarly, the indeterminacy of death screened in execution films, and in Christina Mirabilis' biography, provokes an existential charge for audiences, both medieval and modern. These texts all portray death as a reversible phenomenon.

Spectators of execution films were under no illusions as to what they would witness on screen, made plain by the films' descriptively grisly titles. Some films, such as An Execution by Hanging (Mutoscope, 1898) depicted the real death of an individual, whilst others were dramatic reenactments, such as The Execution of Mary Queen of Scots (Edison, 1895). ${ }^{68}$ Hybrid forms fused authentic footage with dramatic retellings of historical events, confounding categorizations of the on-screen deaths as 'real' or 'fictional'. These composite movies keenly elucidate the role of cinema as a space in which the limits of death are explored, as fiction films show 'real' deaths of the condemned criminal. The 'reality' of such executions is undercut by the ability for the spectator to see the 'authentic' event again and again, by viewing the film multiple times. Execution of $C$ zolgosz, with Panorama of Auburn Prison (Edwin S. Porter, 1901) documents the execution of the anarchist Leon Czolgosz on 29 October 1901. ${ }^{69}$ On 6 September of the same year, Czolgosz shot American President William McKinley at the Pan-American Exposition in New York. Shortly thereafter McKinley died, and Czolgosz's fate in the electric chair was sealed. The crime, and the anarchist's execution, were global news and of obvious public interest. Indeed, many people applied for tickets to Czolgosz's electrocution, though only twenty-six non-transferable invitations were issued. ${ }^{70}$ Thomas A. Edison's film company moved to capitalize on the public's compulsion to see Czolgosz's comeuppance directly, by bringing the action of the event before myriad eyes in filmic form with Execution of Czolgosz. Authentic footage of Auburn prison's exterior, shot on the day of Czolgosz's execution, opens

66 Sobchack, Carnal Thoughts, p. 270.

67 Ibid., p. 269.

68 Somewhat confusingly, Mutoscope (partnering with Biograph) released an identicallytitled remake of An Execution by Hanging in 1905, which featured a re-enacted rather than real execution.

69 On this film, see in particular Doane, pp. 147-50; Musser, pp. 187-90.

70 'Execution of Czolgosz', New York Times, 15 October 1901, p. 11; 'Begging to See Czolgosz's Death', New YorkJournal, 22 October 1901, p. 1. Cited in Musser, p. 187. 
the four-minute work. Although Edison intended to film the anarchist's actual death, permission was denied. Instead, the film offers audiences an experience that the film company described as 'a realistic imitation of the last scene in the electric chair'? ${ }^{1}$

In Execution of Czolgosz, the audience witnesses in one instance a genuine and an illusory death. The execution has already taken place; Czolgosz is certainly dead. Yet, the film's execution is also undeniably a fiction. A fiction rendered even more unreal by the medium of film itself, which allows Czolgosz to rise from the dead and be put to death again and again, whenever the film is screened. Repetition similarly governs the time-scape of the vitae of the Liégeois holy women. ${ }^{72}$ The texts function as extended exempla, drawing salvific and symbolic power from the fact that the protagonists were the audience's near contemporaries. Thanks to the holy women's accessible examples, the faithful were drawn closer into God's embrace. The biographies, then, are 'salvational stories that "happen" at the very moment they are being told'. ${ }^{73}$ Theresa Sanders formulates an identical argument as to the experiential immediacy of martyrdom narratives, thereby contending that 'movies are our modern passios'.74 Sarah Kay also connects martyrdom narratives to filmic works, though on the basis of content and genre. ${ }^{75}$ She argues that Wace's (d. c. 1183) AngloNorman Life of St. Margaret has 'the perfect cast for [a] snuff video': the holy martyr wants to die (thereby attaining perfection), and her pagan tormentor wants to kill her. In other words, the text closely follows the logic of an execution film. As in the bona fide execution film, there is no question that the protagonists of the vitae are literally dead. And yet: they spring back to life for the texts' audience. Christina can 'rise from the dead' whenever her text is read, her corpse reanimated meditatively by her audience. The resuscitations evident in her tale serve as vivid examples of the temporal rhetoric which underpins the reception of the entire Liégeoise corpus. Moreover, the potential for Christina's reanimation is intensified

71 'Edison 1901 Projecting Kinescope' [advert], New York Clipper, 16 November 1901, p. 832. Cited in Musser, p. 187 .

72 Mulder-Bakker, 'Two Women', p. 95. Mulder-Bakker extends Gurevich's arguments as to the experiential 'presentness' of medieval Latin exempla: Gurevich, 'Medieval Chronotope', pp. 229-34. On this, see also Le Goff, Imagination, pp. 78-8o. Gurevich draws from Bakhtin's conception of the 'chronotope', the specific spatio-temporal configuration present in a given text: Bakhtin, Dialogic Imagination, pp. 84-258.

73 Mulder-Bakker, 'Two Women', p. 95.

74 P. 23.

75 Kay, Contradictions, p. 221. 
due to the fact that she is a near-contemporary to the thirteenth-century readers of her vita, which was written roughly eight years after her third death in 1224. By contrast, a holy woman like St. Margaret is an antique of the long-ago days of Christian martyrdom: she is already acutely dislocated from the contemporary moment in which her text was composed.

In some sense, Execution of Czolgosz is also a 'salvational' and exemplary tale. It makes plain the fatal consequences of criminality, showing the swift justice wrought after Czolgosz's murder of President McKinley, a potent symbol of the USA and democracy itself. A modern, if ideologically distant, parallel is found in the beheading or martyrdom videos produced by the Islamic State terrorist organization (IS; also known as ISIL; ISIS; Daesh). The 'exemplary' videos demonstrate what happens if the Islamist ideology promulgated by IS is not followed, be that the execution of enemies or the launch of widespread terror attacks by the fundamentalist faithful. In addition, such digital films often explicitly convey a message as to how to avoid similar violence, wrought against higher numbers, in future. For example, warnings as to the removal of foreign troops from IS strongholds serve to educate non-IS viewers on the 'correct' behaviour so as to escape from harm. Similarly, Christina's purgatorial sufferings emphasize the authenticity of divine punishment, and her resurrection effectively 'reifies the mechanisms of judgement. $7^{6}$

From inquisitorial records from the mid-thirteenth century, it is clear that heretics of various different flavours were united in one particular sense. ${ }^{77}$ Many heretics, including the Albigensians, challenged the orthodox position on divine judgement after death, with some entirely repudiating the notion of any judgement whatsoever. As such, Christina's physical testimony as to the reality of purgatory legimitizes the brutal violence of the Albigensian crusade (1209-1229), a twenty-year campaign to annihilate the heretics of southern France. Certainly, Christina's post-resuscitation behaviour seems startlingly violent, as she systematically attacks her body with fire, water, and cold..$^{78}$ Nevertheless, all of Christina's sufferings conform to models of purgatorial punishment evident in other medieval texts. ${ }^{79} \mathrm{Her}$ repeated exposure to flames, water, and frozen conditions are explicit signs of her enduring purgatory in the here and now of the mortal world. Christina's self-mortification

76 Elliott, Woman, p. 76

77 Ibid., pp. 76-77.

78 See $V C M, 1.11-12.65^{2}$. See also her episodes of self-mortification and mock executions: ibid., 2.14.653; $113.652-53$.

79 M.H. King, 'Witness', p. 147; Le Goff, Purgatory, pp. 6-9; B. Newman, 'Introduction' in TCCSL, p. 35 . 
is entirely orthodox: it represents the penitent's purgatorial punishments in strict accordance to doctrine.$^{80}$ Christina's vita is thus a potent weapon in an anti-heretical toolkit, a tale outlandish enough to stick in the mind and keep an audience's attention but also entirely conformist to resurrection doctrines. ${ }^{81}$

In his Otia imperialia, Gervase of Tilbury (d.1228) declared that 'nothing that had ever been done [...] had pleased God so much' as the 'death and extermination of the Albigensians' ${ }^{82}$ In a strikingly similar tone, President McKinley's successor, Theodore Roosevelt, affirmed that 'every other question' was irrelevant when 'compared with the suppression of anarchy': the anarchist was 'the enemy of humanity, the enemy of all mankind'. ${ }^{83}$ In this light, Execution of Czolgosz operates as a means to combat the intolerable 'heresy' of anarchy, which threatened to destroy the capitalist ideals of the USA. In death, Czolgosz becomes a contemptible human placeholder for the entirety of anarchist politics, and his execution concretizes the entire American justice system. In executing the anarchist, the state re-enacts the unspeakable crime that he has committed: the taking of a life. Therein lies part of the appeal of the event for spectators, its deep irony. This correlates with the thrill of Christina's spectacular sufferings for its audience, which overtly seem to be too over the top to be truly orthodox. From another perspective, the apparent reversibility of Czolgosz's death softens the potential shock of witnessing state-sanctioned violence, a troubling reminder of the vituperative power of the government over its citizens. In any case, the film and the vita both demonstrate the harsh ramifications of failing to align oneself correctly with contemporary hegemonic structures, be that Catholicism or democracy. The moral charge of Czolgosz and Christina's example depends on the authenticity of their deaths, and their reanimation before the eyes of witnesses. We need to see them die - and die and die and die - in order to grasp fully the moral imperative of their example.

\section{Resurrection, Resuscitation, and Unfulfilled Promises}

Alongside resurrection, another form of mystical reanimation is possible: resuscitation. In the case of resurrection, an individual is returned from

\footnotetext{
8 Elliott, Woman, p. 76 .

81 Kurtz.

82 3.103.779. 'Interrogatus si mors ac internicio Albiensium Deo placeret, respondit pridem nullum factum regionis illius tantum Deo placuisse;...[].' Ibid., 3.103.778. See also Gervase's invective against Albigensian belief: ibid., 1.2.29-35.

83 Congressional Record; Washington Evening Star, 9 April 1908. Cited in R.B. Jensen, p. 386.
} 
death to life to a glorified body, and cannot die again. With resuscitation, an individual is restored to life from death but is susceptible to dying again. Hence, in his Summa theologica (composed c. 1265-1274), Thomas Aquinas describes resuscitation as 'imperfect resurrection' ('resurrectione imperfecta'). ${ }^{84}$ Nevertheless, those experiencing resuscitation offer a parallel to Christ's resurrection, and foreshadow the resurrection of all mankind following the Second Coming ('ad praemonstrandum quasi in quodam signo resurrectionem ipsius'). As mystical resuscitations of saints showed the historical veracity of Christ's resurrection, Christ's resurrection, in a feedback loop, offers proof as to the authenticity of the saint's own revivification. ${ }^{85}$ In I Corinthians 15.12-17, Paul emphasizes that a belief in general resurrection follows from the fundamental cornerstone of Christian theology: Christ's own resurrection. ${ }^{86}$ Christina, living after death, affirms that, in fact, the 'corruptible is incorrupt' - and a belief in the corruptibility and degeneration of the body into nothingness is a mockery of Christian theology. ${ }^{87}$ The fact that Christina dies three times would seem to lead to a classification of her experiences as repeated resuscitations, as she is obviously susceptible to death. However, Christ explicitly describes her resuscitated body as having a central quality of a resurrected body: incorruptibility. ${ }^{88}$ Thus, Christina's body is both resuscitated and partially resurrected. Christina's imperviousness to physical damage marks her out as one of God's elect, and allows the saint to function potently as an example of a perfectly resurrected body for her community.

Film apparently proffers the means of perfect resurrection, thanks in large part to the erroneous public imagining of film stock (traditional or digital) as an imperishable medium, a substance endowed with incorruptibility thanks to modern manufacturing, as opposed to the Lord's grace. Yet, cinema cannot ultimately deliver on its promise of an incorruptible afterlife. Instead, the spectator is offered a series of resuscitations - repeated imperfect resurrections - rather than any ultimate triumph over death. The fiction of filmic durability correlates with Christina's resurrected and resuscitated body, seemingly eternal as the film is played again and again without incident ('resurrected') yet ultimately prone to extinction

84 Drioux et al. (eds.), part 3, q. 53, art. 3, p. 954.

85 For an example of such reciprocal proofing, see: VILov, 1.6.41.169. Ida of Louvain resuscitates her sister by contemplating biblical cases of resurrection and agents of resurrection.

86 See also: Acts 17.18; 31-32; Romans 8. 11; I Corinthians 6.14; II Corinthians 4.14; 5. 4-5; Philippians 3.21; I Thessalonians 4.12-16; II Timothy 2.11; Hebrews 6.2.

87 Bynum, Resurrection, p. 309 .

88 VCM, 1.7.652. 
('resuscitated', capable of death). Film stock, the material support for photocinematic images, is susceptible to degradation. ${ }^{89}$

Used from 1899 until approximately 1949, nitro-cellulose (or nitrate film) is in 'a perpetual state of decomposition' due to its chemical instability. ${ }^{90}$ Only approximately ten percent of all films produced globally in the silent era before 1930 are extant, whilst about fifty per cent of sound movies survive from the period 1930 to 1955 . So-called 'safety stock', an acetatebased stock, succeeded its nitrate predecessor in widespread usage from the 1950s. However, it too deteriorates due to vinegar syndrome, which causes the film to shrink, warp, and become brittle. In the 199os, polyester-based film stock was developed which appears to be reliably stable, at least so far. Digitization of celluloid offers a hope for cinematic immortality, as analogue film is transferred into files stored on computers. However, the security of the digital format for conservation is also a fallacy, as Jan-Christopher Horak notes. ${ }^{91}$ File corruption can be a monumental problem. In 2000, for example, Pixar Animation Studios prepared for the DVD release of the computer-animated movie Toy Story (John Lasseter, 1995) and discovered that over ten percent of the film's files were either corrupted or missing. Conservation is guaranteed, then, only by having analogue film stock - itself corruptible - upon which one can lay hands, as is the case in at least one movie studio to this day. Moreover, both hardware and software break down, get 'buggy', and ultimately become obsolete. ${ }^{92}$ Storing film digitally in one operating system or file type does not mean it will be accessible forever.

Catholicism, by comparison, delivers on its promises of life everlasting. Though Christina may be imperfectly resuscitated repeatedly, she finally accedes 'to the immortal age of ages' ('ad immortalia secula seculorum') after her third death. ${ }^{93}$ After the cinematic movement of her post-mortem existence, her body returns to stillness. Yet, it continues to exhibit dynamism. When the citizens of Sint-Truiden and residents of the Saint-Catherine monastery open her coffin some seven years after her third death, all are overwhelmed by the grace of divine sweetness. God's grace, functioning as an ever-whirring film projector, continues to (re)animate Christina. The text suppresses any detail as to the state of Christina's corpse in this instance, though the response suggests that the body is not disgustingly

Slide, p. 3 . 
decayed. Rather, it has been 'frozen in time' at the moment of Christina's passing, a fixing highly connotative of the mummification possible through photography. Once the motion of God's projector ceases to animate her, Christina returns to the stillness of the photographic form as a perfectly preserved photogram.

Readers of Christina's vita are left with the lingering suspicion that death may never 'stick' for the mystic. The final two chapters of the vita, appended by an unknown hand after Thomas of Cantimpré's original ending, suggest this most strongly. An old woman in white appears at the monastery of Sint-Truiden in 1249, twenty-five years after the mystic's last known death. This woman advises the monastery to exhume the body of Christina and thereby receive the 'grace of her merits, prayers and glory' ('ipsius meritis \& precibus gratiam [...] \& gloriam') otherwise face 'the displeasure of divine will' ('offensam divini numinis'), and subsequently disappears. ${ }^{94}$ The white-robed woman is most likely Christina herself, though not identified as such. The willingness to make such a presumption is telling. Given the events of Christina's deaths and lives, it seems obvious that she will keep returning from beyond the grave. The fact that the mysterious woman is elderly suggests that Christina is functionally still alive, as she continues to age. Once Christina's body is exhumed, a miracle is received as a woman is cured of her paralysis. ${ }^{95}$ Theoretically, Christina could appear, alive, at any time - there is no telling how many more deaths and resurrections she will undergo.

\section{The Purgatorial Body}

After her third death, Christina's body takes on an almost pure photographic form, crystallised outside of the flow of earthly time. Before this transformation, however, Christina retains a trace of mortality, despite her accession to a resurrected body. The four gifts (dotes) of the glorified body - impassibility, agility, levity, and clarity - allow Christina to endure the torments of purgatory on earth somewhat nonchalantly. Or rather, they should. Though inhabiting a glorified body, Christina can and does feel pain. For example, she lets out gut-wrenching howls of pain during her bouts of extreme self-mortification. ${ }^{96}$ She cannot fully escape her mortal body,

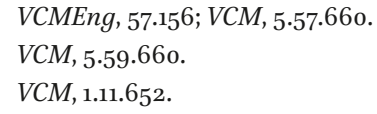


even in her afterlives. So too, the photograph's encapsulation of mortality haunts film. As Mulvey remarks, film retains 'a residual trace of stillness, or the hint of stillness within movement', a sense of the centrality of death (the photogram) which shadows and subverts the moving images' promise of perpetual life. ${ }^{97}$

Christina's passibility emphasizes that the line between resurrection and resuscitation can be very blurry indeed. This ambiguity is problematic, as it points to a potential lack of spiritual authenticity. For example, the widely popular late thirteenth- or early fourteenth-century Pseudo-Albertine text De secretis mulierum recounts Galen's cure of a certain woman who appeared to be dead, complete with loss of pulse and total stasis. ${ }^{98}$ One of the text's medieval commentators ('B') connects such episodes of 'resuscitation' with spiritual charlatanism. ${ }^{99}$ Indeed, Christina's own community initially believe her resuscitation to be the result of demonic possession. ${ }^{100}$ Given the bizarre behaviour the holy woman exhibits once she returns to the mortal realm, this is perhaps unsurprising. Additionally, Christina's ability to feel pain suspiciously negates her claims as to inhabiting a glorified body. Her painful bodily experiences also connect her uncomfortably closely to the still-living Christian. The consequence of sitting in ovens is overwhelming pain, 'just like [for] any of us' mortals ('velut aliquis nostrûm'). ${ }^{101}$ The precise nature of the authorial equivocation here is unsettlingly unclear. Is Christina's experience similar to that of a still-living individual? Or will a now-living individual ultimately experience what Christina feels, perhaps during a lengthy stint in purgatory? Or both? Categorizing Christina's resurrection as devilish in nature is a forcible rejection of the horrifying (and accurate) alternative: that, in purgatory, all Christians will eventually endure similar torments as the holy woman.

Thomas of Cantimprés prevarication about the practical complexities of Christina's resurrected form reflects a widespread preoccupation of the thirteenth century, a period in which theologians debated the nature of the resurrected body at length. ${ }^{102}$ For example, the Council of Lateran IV in 1215 insisted that all 'will rise again with their own bodies, which they now bear' ('omnes cum suis propriis resurgent corporibus, quae nunc

97 Mulvey, Death, p. 67.

98 Pseudo-Albertus Magnus, 11.114.

99 Lemay (ed. and trans.), 11.134; Elliott, Woman, pp. 207-08.

100 VCM, 1.9.652; 2.17-19.653-54.

101 Ibid., 1.11.652; VCMEng, 11.133.

102 Bynum, Resurrection, pp. 229-343. 
gestant'). ${ }^{103}$ This pronouncement was restated in the Second Council of Lyon in $1274 .{ }^{104}$ The vast majority of theologians of the later medieval period agreed that 'God will reassemble and reanimate at the end of time the same material particles [...] of which the body was composed on earth'. ${ }^{105}$ Though theologians maintained that the resurrected body remains whole, in the sense that it continues to possess all 'aspects and elements of its earthly structure', the exact method of the body's reconstitution and its make-up remained topics of intense discussion. ${ }^{106}$ Whatever is doctrinally authentic for Christina, the holy woman's suffering makes plain the inevitable suffering to come for all sinners in purgatory. Escaping death does not mean escaping the body, or pain.

Above all, Christina possesses a purgatorial body. This body shares some similarities to her pre-mortem body. For example, it looks the same and it can feel pain. However, the soul makes its presence deeply felt in the body's new mode. This is reflected by the purgatorial body's typical lightness, and reduced tolerance to the heaviness of earthly objects. Christina's post-mortem body is 'so subtle and light' ('tantae subtilitatis, \& levitatis') that she can walk at dizzying heights, and hang suspended from slender branches of trees. ${ }^{107}$ On one level, the 'subtlety' of Christina's body lies in its status as a glorified resurrected body ${ }^{108}$ However, given the holy woman's passibility, this corporeal lightness makes it evident that she possesses a purgatorial body. For example, in Gervase of Tilbury's famous 'Ghost of Beaucaire' exemplum, a revenant from purgatory explains that 'the lightest straw' ('leuissimam paleam') is 'an unbearable weight' ('sustineri non posse') to those in purgatory ${ }^{109}$ What's more, the visitor proclaims that 'the slightest pain of purgatory is harsher than any bodily suffering. ${ }^{110}$ In purgatory, the body and its discontents are not overcome. Rather, an individual's physical experience and response to stimuli is intensified.

Dealing with a purgatorial body is a difficult proposition for Christina. She is stuck between states: a being paradoxically both fully mortal and

103 Denzinger (ed.), p. 266, DS 801.

104 Ibid., p. 283, DS 854.

105 Bynum, Resurrection, p. 276.

106 Ibid., p. 238.

107 VCMEng, 15.136; VCM, 2.15.653.

108 VCM, 1.6.651. McGinn, p. 161; Sweetman, p. 619 .

109 3.103.768-69. This tale (pp. 758-89) reflects much of the prevailing understanding of purgatory in the thirteenth century. See also: ibid.,1.20.112-15; 3.17.588-91. For analyses of the Beaucaire account, see in particular: Bresc; Cherchi; Schmitt, pp. 87-92.

110 Gervase of Tilbury, 3.103.773. '[...] minimamque purgatorii penam quauis corporali pena esse asperiorem.' Ibid., 3.103.772. 
wholly spiritual. This is powerfully evoked in an emotional dialogue between body and soul, voiced entirely by the holy woman. ${ }^{111}$ The fraught relationship of body and soul is primarily expressed in terms of a reciprocal sense of temporal dislocation. Christina's soul bewails the fact that her body delays its return to God's plenitude ('detinere', 'retardabis'), forcing it to remain on earth for so long ('diu [...] diu'). Equally, her body questions why her soul refuses to let it rest in the slumber of death: 'Why do you not allow me to return to the earth from whence I was taken, and rest until I am restored to you on the last day of judgement? Why do you not go to your rest, so that you might enjoy more desirable things in heaven? ${ }^{\prime \prime 2}$ Both body and soul yearn for a form of timelessness, though their preference for the specific type of a-temporal experience differs. The body craves the stillness of the photograph, a fixing in time that will be reversed if the photograph becomes a photogram, and is then revivified by the divine projector. The soul desires a form of perpetual revivification, becoming a part of God's never-ending film. Christina's soul, then, wishes to be contained by a body different to the biological organism. Instead, it wants to become subsumed in the (divine) filmic body, that 'direct means of having and expressing a world' which equates to 'the immediate experience of consciousness. ${ }^{113}$

This analysis of Christina's precarious situation allows us to disentangle the temporal dynamics at play in The Dark Knight (Christopher Nolan, 2008), a film which stages the interplay between body and soul in the accession of immortality, thanks to the circumstances of its release - a principal actor's death. ${ }^{114}$ Transposed to our modern secular world, 'body' relates to the biological fact of an actor's death, that stillness which haunts the photograph. 'Soul' corresponds to the actor's apparently eternal existence as a character in a film, and ultimately as the film itself. The Dark Knight was Heath Ledger's penultimate film. ${ }^{115}$ Ledger died six months before the

$111 V C M, 5 \cdot 47-48.658$.

112 VCMEng, 48.151. 'Quare non sinis me redire ad terram, unde assumptum sum, \& quiescere, quousque tibi in novissimi judicii die restituar? Quare non vadis ad requiem tuam, ut fruaris potioribus in supernis?' $V C M, 5 \cdot 48.658$.

113 Sobchack, Address, p. 168. Emphases in original.

114 For a summary of film theorists' usage of the concepts of body and soul, see: Cooper, pp. 108-51.

115 See also analyses of this issue in relation to Marilyn Monroe (d. 1962) and her role in The Misfits (John Huston, 1961) in: Salzberg. Cf. Paul Walker's performance as Brian O'Connor in Fast and Furious 7 (James Wan, 2015), which similarly highlights the confusion of categories of life and death inherent in film. An important point of departure: Ledger had completed his role before he died; Walker died mid-shooting. The final film incorporates authentic footage of Walker and scenes featuring his digital double. 
release of the movie in which he played Batman's nemesis, the Joker. Ledger's death was widely publicized by media outlets, and the majority of spectators watching the film likely knew the actor had died before seeing the film. In much the same way, the signification of Christina's vita is founded on the holy woman's death, described in detail at the text's opening. Ledger's death radically oriented the reception of the Dark Knight, in terms both of its financial success and the impact of the character of the Joker on the audience. Reports of the actor's death functioned as free publicity for the movie, and 'supercharged' the 'allure' of the film, enticing droves of spectators. ${ }^{116}$

Death does not decisively end Ledger's existence, as he lives on as and in the Joker. This conflation was intensified by the fact that Ledger was posthumously awarded a Best Supporting Actor Academy Award for his performance in The Dark Knight. The quality of his acting, crystallized in his portrayal of the Joker, endures for perpetuity. Ledger's post-mortem screen presence evinces an unsettling 'spectral quality', magnifying our fascination for the Joker and our sense that Ledger and the Joker have merged into one. ${ }^{117}$ To some, the Joker's psychology became Ledger's inner life, and vice versa. For example, New Yorker film critic David Denby remarked that 'as you're watching him, you can't help wondering [...] how badly he messed himself up in order to play the role this way. His performance is a heroic, unsettling final act: this young actor looked into the abyss. ${ }^{1{ }^{118}}$ More recently, the (re)discovery of Ledger's 'Joker diary', the notes he wrote during the monthlong period of sequestration in which he prepared for his role, was hailed in the media as evidence that the actor began to slide, at least partially, into the Joker's mania. ${ }^{119}$ The spectrality of Ledger's performance amplifies one of the Joker's core characteristics, a troubling slipperiness. The Joker is a barb under the skin of Gotham City: a presence felt all too painfully, yet almost impossible to capture in the pincers of justice. The majority of The Dark Knight's plot revolves around the hunt for the Joker. Although the police capture him mid-way through the movie, he manages to escape. Ultimately, the Joker is re-captured at the end of the film. Yet, this offers little closure to the spectator. He has escaped once, surely he could do so again: the Joker can never definitively be marked as absent. In the event of a remake of The

116 B. Gray, n.p. On the film's marketing strategy after Ledger's death, see: Carroll.

117 Pheasant-Kelly, p. 137.

118 N.p.

119 The diary features in the 2012 German television documentary about Ledger's life, Too Young to Die - Heath Ledger (Dag Freyer). For a representative sample of the news reports, see: Chester and White; Hooton. A clip from the documentary (re)surfaced online in 2015, re-igniting interest in Ledger's death. 
Dark Knight, or a reboot of the Batman saga more generally, the Joker may return in another body, animated by another spirit (a different actor, and his interpretation of the role).

With God's grace, Christina resolves the friction between body and soul. Ventriloquizing the spirit, she seizes upon the gracious forbearance of the body that has 'patiently endured the torments and hardships' ('labores benignissimè ac patientissime pertulisti') imposed by the spirit. The body must only wait a little longer for death. Shortly thereafter it will be 'purified of all corruptibility' ('deposita omni corruptibilitate') via resurrection, thereby reanimated into the ceaseless divine film to meet the soul once more. ${ }^{120}$ Christina's body wishes to divest itself from the cinematic screen, to revert to the photographic stillness of mortal death. Her soul wishes to be ineluctably on the screen, entirely subsumed into God's munificence, in the same way in which we experience Ledger's post-mortem presence. At the moment in which the dialogue takes place, Christina is in the fraught position of the purgatorial body, existing in-between both poles - being neither mortal (photograph) nor immortal (film) decisively - but instead enduring as an artefact of the screen. In a similar way, The Dark Knight's Joker presents a paradox: he is a presence and an absence at once. This dichotomy is emphasized by the way in which the Joker makes himself radically visible in Gotham. To spread his messages of terror, he distributes video messages to news networks. When these videos are played, the Joker simultaneously exists everywhere in the city on myriad screens, whilst also remaining indubitably 'elsewhere'. The Joker is not fully off or on the screen, but rather inhabits a plane somewhere in between. Like Christina during her dialogue, the Joker inhabits a purgatorial body. He exists of the screen, as Ledger himself has become after his death. The Dark Knight's filmic body acts as a substitute for Ledger's own body, a manoeuvre strengthened by the explicit dedication of the work 'in memory of' the actor in the film's credits. ${ }^{121}$

\section{Liturgical Time}

Repetition and circularity orient the temporal plane of both modern cinema and medieval Catholicism. Thanks to developments of film technology,

120 VCMEng, 49.152; VCM, 5.49.658.

121 The film is also dedicated to Conway Wickliffe, a special effects technician who perished whilst shooting a stunt. Though Wickliffe is certainly memorialized with this tribute, he does not appear in the movie overtly and thus he is not similarly embodied by the film. 
movie watchers can replay a film at will, reliving its plot over and over by pressing the appropriate buttons on their DVD player, computer, or smart device. It is this capacity for repetition that allows Ledger to spring to life as the Joker, as long as the spectator has the required technology to hand. Similarly, the liturgical calendar was a form of temporal machinery which brought the divine diegesis into the quotidian routines of medieval Catholics, directing them to relive biblical history in a yearly cycle. ${ }^{122}$ Juliana of Mont-Cornillon, for example, follows the rhythms of the liturgical year assiduously, and emotionally relives each biblical event in her contemporary moment. ${ }^{123}$ Elisabeth of Spalbeek's biography offers a more intense version of liturgical re-enactment. Elisabeth acts out the Lord's Passion daily whilst in ecstasy, anchoring the sequences of her performance to the day's liturgical Hours, from matins to compline. ${ }^{124}$ Her interpretation operates as a personal microcosm of Holy Week, the period before Easter in which the Crucifixion is commemorated. Philip of Clairvaux situates his account of Elisabeth's behaviour in the past. Whilst visiting Liège, he was compelled to visit the holy woman and witness for himself her miraculous performances. ${ }^{125}$ However, his narration of her re-enactments slips in and out of the present tense, endowing Elisabeth's performance with a sense of eternal present-ness. In a sample passage describing Elisabeth's incarnation of the beginning of the Lord's Passion, for example, Philip notes that:

At another subsequent point of time, as if she were being violently dragged vertically in an upright position, she flings herself from one place to another with a peculiar swift motion, [...]. She fixes her gaze with eyes that inspire terror; and she conveys a sense of dreadful horrors and terrors through significant glances, hand gestures and nods of her head. ${ }^{126}$

The author embeds Elisabeth's actions in a vague linear chronology: these events follow that other 'point of time', and thus occur in a historicized trajectory. Yet, the repetition of potently active verbs in the present tense - 'tractus', 'transfert', 'traheretur', 'intuetur', 'exprimit' - insists upon

122 Mulder-Bakker, 'Two Women', pp. 87-88.

123 VJC, 1.4.16.449-50; 1.4.18-19.450-51.

124 VES, 3.363-64.

125 Ibid. 2.363 .

126 VESEng, 4.3-4.4. 'Aliquando vero recte in antea, quasi ex tractus violentia, per varias vicisstudines impetu quoadam præcipiti localiter se transfert, ac si ab aliis nequissime et violentissime traheretur [...]. Terribilibus oculi intuetur; oculis ac manibus, signis et nutibus horrores exprimit et terrores.' VES, 4.364 . 
the immediacy of the holy woman's performance. The alliteration and consonance of ' $t$ ' in these verbs lends a percussive rhythm which further emphasizes Elisabeth's dynamism in the here and now, in a present-ness which overspills from the text into the present moment of the text's reception. Elisabeth's re-enactments exemplify the way in which the liturgy superimposes 'the time of God' ('le temps de Dieu') onto the chronology of the mortal realm. ${ }^{127}$

In her study of the seemingly random tense switching evident in texts from the Middle Ages, Mary Carruthers argues that the present tense operates as an 'unmarked tense-without-time' for medieval authors. ${ }^{128}$ Narrative, she argues, 'is basically construed in the present'. Although the past 'is the ordinary time of narrative, [...] the present is the basic tense of narrative.' Elisabeth's biography demonstrates that the narrative of the liturgy - that is, a believer's lived experience of the liturgical calendar - is experienced in the present 'tense'. In this context, the temporality of film spectatorship may be termed 'liturgical'. Narrative film presents its plot to the audience in the present tense: the drama unfolds in time of the movie's running length. The movie's diegetic 'time' is dislocated from the present moment. By necessity, the film's events were shot prior to the viewing experience. What's more, the film may purport explicitly to show a time different to our own: the past of a period flick, or the imagined future of science fiction, for example. Nevertheless, this diegetic time is experienced as the spectator's own. With repeated viewings, this diegetic time correlates with the viewer's specific temporal moment again and again. The spectator's immersion in the ever-unfurling present tense of the film is at once personal and public. On one level, they are immersed individually in the film. If we widen our focus, though, we see that countless others have a personal viewing experience of their own. In much the same way, the medieval Catholic has an experience of biblical history according to the liturgical calendar that is at once individual and communal.

The liturgy, in Jacques Le Goff's words, is 'a remembrance of the resurrection of Christ, an expectation of his return, and communion with him.'129 Whilst Elisabeth of Spalbeek performs liturgical time, Christina Mirabilis embodies it. Through her multiple revivifications, Christina literally incarnates the circular logic of liturgical time, and the inevitable return of Christ. It is important to appreciate, however, that the liturgy is a timeline 
ultimately controlled by the Church. Accordingly, Christina's (re)insertions into the mortal timeline concretize doctrinal teaching on the nature of purgatory and the resurrected body. As such, she acts as a conduit to allow the rhetoric already governing Christian life to be re-(in)stated visibly.

The nature of the liturgy as a means for the clergy to control spiritual women is further elucidated in Lutgard of Aywières's vita. Shortly before her death, Lutgard prophesies that God will wreak vengeance on her spiritual sisters at Aywières. ${ }^{13^{30}}$ The nuns have refused to heed Lutgard's warnings on the importance of observing the canonical Hours assiduously, a defect for which the Lord will punish them harshly. Lutgard is proved correct. Just after her own death, the convent is ravaged by a 'grievous plague' ('pestilentia gravis') which kills fourteen nuns. These victims were some of the convent's 'most proven' ('Moniales probatissimae') sisters. Even the most superficially spiritual of women can harbour the sinful secret of disobedience to the liturgy. The temporal disorder for which the plague victims are guilty is mirrored in the 'disordered' manner in which they are buried. Lutgard's biographer, Thomas of Cantimpré, notes that he himself buried two nuns in a single grave.

The nuns' disobedience of the temporal regime of the canonical Hours allows Thomas to disrupt the chronological flow of his own text. At the end of the episode, Thomas switches to the present tense in order to address his readership directly: 'I therefore beg you, ladies and sisters of Aywières, to observe all of Lutgard's precepts as best as you can and follow in her footsteps. And I hope that, by her prayers, you will achieve the palm of victory $[. . .]^{3^{131}}$ The tense in which Thomas' remarks are deployed parallels the ever-presentness of the liturgical moment itself. Moreover, Thomas presents correct observance of the Hours as a metonymy for acceptable - and effective - spiritual conduct, epitomized in Lutgard herself. Indeed, the holy woman has previously demonstrated an obsession for the perfect observation of the canonical Hours, attempting to empty her mind of all thoughts during her recitations. ${ }^{132}$ Consequently, Lutgard repeats each Hour two or three times. She overlays her recitation(s) over the previous attempts, meditatively rewinding time to 'record' her new prayers over the old ones. Each time she re-recites an Hour, she acts as if she had said nothing at all' ('quasi nihil dixisset') before. As she tries to obey consummately

$130 V L A ., 3 \cdot 2.14 .259$. See also Margaret of Ypres' difficulty in obeying the liturgy due to her raptures: $V M Y, 18.115,20.116-17$.

131 VLAEng, 3.14.286. 'Rogo ergo vos ô Aquiriæ Dominæ \& Sorores ut piam Lutgardem in omnibus dictis quæ observare poteritis observetis: exemplorumque ejus inhærete vestigiis, \& spero quod ejus precibus pervenietis ad palmam [...].' VLA, 3.2.14.259-6o.

$132 V L A, 2.2 .17 .247$. 
the strictures of the liturgy, Lutgard gets stuck in a temporal loop, as if one replays the same few minutes of video over and over. As with a visual segment removed from its coherent plot - such as a GIF, a digital video clip which perpetually loops a selected few frames extracted from a filmic source - Lutgard's looping divorces the canonical Hours from their context, the rest of the liturgy, and thus the divine story. In response to her friends' prayers, the Lord visits Lutgard in the form of a shepherd, reassuring the holy woman that her prayers are pleasing. The Lord forces Lutgard to escape her temporal loops, and reinstates her into liturgical chronology.

The liturgy overlays time with ecclesiastical ideology. The liturgical' time of film spectatorship also bears the weight of ideological signification, that of linear chronology and its teleological impetus. With the vast majority of 'mainstream' pop-cultural film, the audience sees a contiguous beginning, middle, and end which flow into one another. The rhetoric of sequentiality, of cause and effect, organizes our understanding of the plot, the 'message' of the film. Yet, most films radically compress time. The 'present tense' of the movie's running length is not, actually, real time. Rather, the director evokes - rather than literally shows - minutes, hours, and even decades. In the editing room, a certainty that cause leads to effect is manufactured by the filmmaker. The Church achieves a similar result - the infallible logic of the inevitability of Christ's return and the authenticity of doctrine - with the liturgical calendar.

Alongside representing the perpetual circularity of liturgical time, Christina Mirabilis' return injects a sense of urgency into the earthly timeline. According to Thomas of Cantimpré, Christina demonstrates the inescapability of death and the concomitant necessity of readying oneself spiritually for the everlasting: 'Watch therefore, because you know not the day nor the hour when your Lord will come [cf. Matthew 25.12-13]. What else did Christina cry out during her entire life except to do penance and be ready at every hour? ${ }^{1{ }^{133}}$ Christina's resurrection(s) instantiate the teleology of the mortal linear chronology: an inescapable countdown to death. In this way, her resurrection(s) mirror the impact of Christ's Incarnation, which gives Christian time 'a historic dimension' and 'center'. ${ }^{134}$ Christ's appearance on earth allowed for the construction of a 'before' and 'after' (anno domini). Moreover, it signalled the 'certainty of eventual salvation with him' in the future. The Incarnation, then, refers simultaneously to the past and future,

133 VCMEng, 56.155 . 'Vigilate ergo: quia nescitis diem neque horam, qua Dominus vester venturus sit. Et quid aliud in omni vita sua Christina clamavit, nisi poenitentiam agere, \& paratos esse homines omni hora?' VCM, 5.56.659.

134 Le Goff, Culture, p. 31. 
thereby opening up the space of the contemporary moment. In this space of present-ness, Christians - collectively and individually - are compelled to take action to ensure salvation is achieved. In a similar manner, Christina's resuscitations establish the legitimacy of Christ's first resurrection and his Second Coming, whilst forcing believers to appreciate the role their current behaviours play in their experience of salvation. The linear chronology invoked by Christina's example will ultimately fracture, giving way to the a-temporal plenitude of heaven - but only after one navigates that other temporality, the time of purgatory.

\section{Purgatorial Time}

In her post-resurrection 'life', Christina also incarnates a linear temporality that runs parallel to, and intersects with, terrestrial time: purgatorial time. ${ }^{135}$ Indeed, therein lies the urgency that the holy woman generates for those around her. Purgatory is coming for you, her body proclaims, this is what it looks like, this is how it works, and this is why you must act now to limit your exposure. Christina's purgatorial torments are discontinuous with mortal time. For example, she exposes her feet and hands to flames 'for so long that they would have been reduced to ashes had it not been a divine miracle. ${ }^{136}$ Frequently, she rests at the bottom of the river Meuse 'for six or more days at a time' ('sex diebus \& eo amplibus'). ${ }^{137}$ Her mock executions, in which she hangs herself between thieves in the gallows, last for 'one or two days' ('uno die vel duobus'). ${ }^{138}$ These self-inflicted tortures are emphatic intensifications of mortal temporality. Notionally, any of these activities should take mere minutes to kill an individual. For Christina, the minutes of mortals stretch out for days. Her experience of a 'thickened' temporality reflects the fact that time in purgatory often seems to progress more slowly than earthly time. For example, in an exemplum from Caesarius of Heisterbach's Dialogus miraculorum (Dialogue of Miracles; completed $c$. 1222), an apostate monk returns to earth in a series of visions, and proclaims that two years on earth equate to two thousand years for him in purgatory ${ }^{139}$

135 On purgatorial time, see in particular: Le Goff, Imagination, pp. 67-85; Purgatory, pp. 229-30, pp. 290-95; Mills, 'God's Time?'; Schmitt, pp. 171-78.

136 VCMEng, 11.134.1. 'tenebatque tam diu, quousque, nisi divinum esset miraculum, redigi in cinerem potuissent.' $V C M, 1.11 .65^{2}$.

137 VCMEng, 12.134; VCM, 1.12.652.

138 VCMEng, 13.135; VCM, 1.13.652.

139 I, 2.2.61. On the relationship of earthly to purgatorial time, see also: ibid., I, 4·30.198-202. 
Although purgatorial time differs to earthly time, the latter fundamentally structures the former. Events undertaken by the living in the flow of terrestrial time - namely prayers and suffrages - directly impact the length of a soul's stay in purgatory. As Marie de France (d. c. 1189) formulates in her twelfth-century account of the Irish knight Owein's foray in purgatory: 'When we pray for them [/] Or offer masses, donations, and gifts, [/] Their suffering is diminished: [/] Either they are relieved of all their suffering, [/] Or are alleviated of some of their pain, [/] Or are placed in lesser pain. ${ }^{140}$ This dynamic underpins Christina's vita: she takes on the purgatorial sufferings of souls in her own body to expiate them in advance of their death. ${ }^{141}$ What's more, by bringing purgatorial time into the mortal realm, Christina demonstrates that an individual's time on earth should be spent with a keen eye on the consequences of sin, in order to avoid a distressing sojourn in purgatory. In the life of a devout believer, the anticipation of purgatorial time organizes the way in which they spend each day in the mortal world: purgatorial and terrestrial time are dialogic and interdependent. If the spiritual offerings of the living are to have any meaning, time in purgatory must be quantifiable: 'a measurable sequence with a clear beginning and end [...] bound up with units of terrestrial time.. ${ }^{142}$ This logic is perhaps best illustrated in the indulgence, an ecclesiastically approved mechanism by which an individual may pre-emptively buy time off their sentence in purgatory. ${ }^{143}$ The fact that Christina's torments are figured in terms of terrestrial units - multiple days of hanging in the gallows, for example illustrate their location in the chronological framework of purgatory. After all, a 'normal' hanging in the mortal world needs no temporal markers. An individual simply hangs themselves, full stop.

With the heuristic of purgatorial time, the chronological complexities of The Dark Knight's narrative can be unpacked further. The Joker explicitly terms his attacks on Gotham as 'the battle for Gotham's soul'. However, this conflict is not a 'simplistic tale of good and evil', a characteristic of many superhero films which often present the categories of villain and hero as completely discrete. ${ }^{144}$ Rather, the Joker's 'battle' forces Batman and the citizens of Gotham to confront the stark realities of their individual moral

140 Curley (ed. and trans.), pp. 142-43, ll. 1759-64. 'Quant hum fait pur els oreisuns, [/] messes, e almosnes, e duns, [/] lur torment sunt amenuisié [/] u delt tut en sunt alegié: [/] u l'um aliege lur dolurs, [/] u l'um les met enz en menurs.' Ibid. Cited in Mills, 'God's Time?, pp. 479-80.

141 VCM, 1.6.651.

142 Mills, 'God's Time?', p. 48o.

143 Ibid., p. 482. On indulgences, see Le Goff, Imagination, pp. 74, 76 .

144 Ebert, n.p. 
compasses. Each of the Joker's terroristic attacks on the innocent is designed to make his victims confront the capacity for criminality and immorality that resides within each of us. Strikingly, the Joker's aggressions 'depend on exact timing. ${ }^{145}$ This is in direct contrast to the non-specific temporal landscape of the rest of the film. The Gotham with which we are presented is neutrally contemporary to us, a viable proxy for a twenty-first century metropolis. The primary identifiable character of the city is its rampant capitalism, be that in the business interests of billionaire Bruce Wayne (Batman; played by Christian Bale) or the criminal enterprises of mobsters. The Joker constantly forces Batman, and the entire city, to race against the clock to find salvation, imposing purgatorial time on Gotham by force.

The quantitative system of indulgences affords the living some kind of control over the torments to which they will be subject after death. Pay the right amount, be that in terms of money or appropriate devotional activities, and one could theoretically bypass purgatory completely. The Joker, however, rejects this central organizing mechanism of purgatory: he forces his victims to inhabit the purgatorial chronotope without access to such a comforting escape route. Unlike the rest of Gotham's criminals - and indeed the wealthy captain of industry Bruce Wayne - money does not motivate the Joker. He stands apart from the destructive materialist capitalist ideology which taints others, issuing his demands in the form of cruel moral dilemmas for his victims instead of dollar amounts. His victims cannot buy him off, and thereby escape their punishment. In the Joker's own words, his criminality is 'not about the money, it's about sending a message'. More than anything else, the Joker abhors the unfairness of moral equivalency of which everyone in Gotham is guilty, a fact he makes plain in a soliloquy delivered shortly before he blows up a hospital. Chaos is his weapon of choice, as it is genuinely 'fair'. Had he resorted to killing the usual suspects, 'gangbangers' or soldiers, Gotham would be indifferent. His targeting of prominent figures like the mayor and the only superficially innocent citizenry of Gotham makes everyone pay attention, forcing all to reckon with their own moral turpitude.

Film critic Justin Chang argues that Ledger's 'complete and frightening [...] immersion' in the Joker role is central to the exquisite quality of his performance as a piece of 'indelible' actorly work. ${ }^{146}$ Ledger 'makes the viewer entirely forget the actor behind the cracked white makeup and

145 Pheasant-Kelly, p. 136.

146 N.p. For a compilation of critics' reception of Ledger's performance, see: Davies. For critical reception to the film as a whole, see: 'The Dark Knight'. 
blood-red rictus grin'. The audience finds Ledger's Joker so fascinating to watch precisely because Ledger disappears from view. The brute force of Ledger's actual lived existence is transferred, at least partially, into his character. This endows the Joker with the aura of something altogether too real. Whilst incontrovertibly a fictional character, he nevertheless becomes an authentic expression of the dark-side of contemporary life: the chaos of post-9/11 terrorism. ${ }^{147}$ Various film critics explicitly interpret the Joker in this context. Chang, for instance, asserts that the Joker is the 'superhero-movie equivalent of a modern terrorist', whilst Tim Teeman classifies the villain as the 'embodiment of anarchy and antiorder'.148

The slipperiness of the Joker's character - a menace that can never be fully contained - echoes the diffuse character of modern terrorism. Tessellating terrorist cells now operate as a part of a non-centralized yet ideologically united violent force. Such cells are often embedded in the very society which they seek to destabilize. The archetypal post $9 / 11$ fundamentalist Islamist terrorist is no longer an easily identifiable external enemy: they are everywhere, and nowhere at once - just like the Joker himself. This generates a pervasive unease, a terroristic paranoia which colours our culture, reflected in the audience's reaction to the Joker. As Teeman puts its, 'Ledger is so terrifying and unpredictable that his very presence on screen makes you horribly nervous. ${ }^{149}$ The Joker, as an embodiment of post-9/11 terror, corresponds to the terrifying insidiousness of evil, that invisible horrifying danger which lurks in every facet of our world. In the medieval era, this diffuse evil was understood, literally made visible and intelligible, by the reification of such forces into the diabolical, Satan and his minions.

Teeman's reference to Ledger to talk about the Joker's actions in the filmic diegesis is telling. It returns us once more to the conflation of (deceased) actor and (fictional) character which is central to the existential power of the Joker. Maitland McDonagh argues that 'Ledger's mesmerizingly damaged agent provocateur is the film's dark heart, a presence so malevolently unpredictable that it remains palpable even when he's not on screen. ${ }^{15^{\circ}}$ The terrifying potency of this 'presence', inscribed in the very fibre of the film itself, relates not just to the Joker and his anarchic machinations, but to the audience's implicit understanding of Ledger's preternatural existence in and as the film.

147 On this, see in particular: Pheasant-Kelly, pp. 131-42.

148 Both n.p.

149 N.p.

150 N.p. 
Though the Joker is certainly terroristic, he is not a one-dimensional bad guy. His symbolic force lies in a series of juxtapositions held in unresolved tension: actor/character; body/soul; life/death; good/evil. Dana Stevens avers that The Dark Knight functions as a means of 'thinking through $9 / 11^{\prime} .^{151}$ In particular, it shines a light on the ways in which terror 'breaks down those reassuring moral categories' with which movie-watchers attempt to orient their lives. The Joker forces us to confront not only the terrorism which radically organizes contemporary society, but also the problematic nature of the Western response to terrorist attacks. In Frances Pheasant-Kelly's formulation, the 'implication in The Dark Knight is that terrorism exists merely because of the war waged against it, with the film making much of the consequences, namely, the deaths of innocent civilians.' ${ }^{\prime 5^{2}}$ The Joker explicitly admits his dependence on Batman for his criminal life force in a direct address to the caped crusader: 'What would I do without you. You complete me.' In response to terrorist attacks on Western soil, governments retaliate in kind, launching bombing raids across targets in the Middle East. Such interventions are a catalyst for the recruitment of more terrorists, and the entrenchment of fundamentalist Islamist sentiment. Collateral damage is a commonplace of war. Governments, politicians, and soldiers regularly calculate the relative cost to benefit ratio of military manoeuvres: how many lives, and whose lives, may be sacrificed in order to fight terrorism. In the Dark Knight, the Joker forces Gotham's citizenry - and moviegoers - to confront the logic of this system. This takes the form of a temporal drama, as the Joker forces Gotham to inhabit a purgatorial time-space in which he stages a battle for the city's soul.

In his final attack, for example, the Joker rigs two commuter ferries with explosives. One ferry, the suggestively named 'Liberty', transports law-abiding citizens; the other carries prisoners. Unless one group of passengers decides to blow the other up, the Joker will detonate both at midnight. The Joker frames this event as a 'social experiment'. Will the law-abiding passengers recognize the dignity of their criminal counterparts' lives? Will the criminal passengers - referred to as 'scumbags' by their ferry captain - demonstrate their innate brutality, and detonate the other boat without a second thought? With his explosive deadline, the Joker provokes an ethical reckoning. During this sequence, the action flits between the two groups of passengers. Shots of the drama taking place in the two ferries are sandwiched together with four lingering close-ups of a clock face - 11:48, 
11:56, 11:58, and 12:01. The clock is generic, and it is impossible to discern to which ferry it belongs, indicative of the way in which both ferries have been forcibly drawn into the Joker's purgatorial time.

The clock face that reads midnight is not on a ferry, however. Instead, the pivotal moment in time is displayed on the Joker's own clock, a shabby device that is immediately identifiable as different to the ferries' timepiece. Midnight belongs to the Joker. As the decisive moment of redemption, it is the fulcrum of his entire ethical system. If all passengers make it to midnight, then perhaps the Joker is wrong - perhaps, as Batman growls, not everyone is 'as ugly as' him deep down. Overcoming the torments of purgatory allow the medieval Catholic to enter the divine kingdom, whole once more. For the Joker, however, his victims' survival threatens to destabilize his entire worldview and sense of self. It takes approximately eight minutes of screen time for the ferry-bomb sequence to elapse, measured from the first to the last close-up of the ferries' clock. The earthly (spectators') temporality is less intense than that of the purgatorial (ferry passengers') timeline. The spectator experiences the thirteen minutes between 11:48 and 12:01 in a compressed form, in a less overwhelming way than they would if they were really watching a clock count down to a fatal explosion.

Ultimately, both ferries survive. In the process, however, the ethics of the civilian ship are shown to be flawed. The 'Liberty' ferry establishes a democratic process of voting to decide whether to detonate. Democracy is fallible: 396 opt to blow the prisoners up, whilst only 140 demur. By comparison, a prisoner on the other ferry steps up to claim the detonator, and immediately throws it out of the window. He is doing what the chief guard 'should have did ten minutes ago'. This underscores the intersection of post-9/11 ethics and time in the Joker's imposition of purgatory. The morally virtuous option has been evident since the mastermind informed the ferry passengers of their situation. The sin lies, at least partially, in delaying, thinking through the 'unthinkable' of killing hundreds of other people. As the prisoner approaches the chief guard, the clock face hovers behind him. We cannot tell its time - the top of the clock is out of the frame - but can only perceive that the end, midnight, is near. For the prisoner, a symbol of enviable moral fortitude, it does not matter what the time is precisely. What matters is that the end is coming, and he can, and must, act accordingly.

At the end of the ferry-bomb sequence, the final close-up of the ferries' clock fills the screen: 12.01. We see only three more seconds of any of the ferry passengers. The crew and passengers of the prison ship wonder at their survival. By holding strong to their ethics, they have survived the Joker's 
skewed version of purgatory and live on, returned to a linear timeline. In contrast, the civilian passengers remain, at least on the diegetic level, locked in the last moments before midnight - with many more trials to undergo before they find redemption. This sticky purgatorial time enfolds the film's spectators too. After the credits roll, we leave the movie theatre and return to the linear temporality that governs the banalities of our lives. And yet, we are not delivered from the purgatorial chronotope so easily. We remain with the civilian ferry passengers in the final few seconds before midnight comes. Will we make the correct - the most moral - decision when the time comes?

In contemporary society, time has been secularized, flattened into a rational linearity. The moral dimension of time, expressed in the medieval framework of liturgical and purgatorial time, has been disavowed. The Dark Knight forces a realization that this disavowal is both ethically murky and ultimately unrealistic. Our actions matter, more than we might care to admit. We must take into account the moral dimensions of what we do and how we do it, for each action has myriad ramifications down the road, both for ourselves and others. Purgatorial time has been transposed from the purview of the religious to the cinematic, though this shift does not diminish the nature of the chronotope as a space for moral reckoning. That purgatorial time penetrates cinema is thanks, in large part, due to the complex temporal dislocations that structure both Catholic theology and film spectatorship.

\section{Putting Things into Perspective}

In his prologue to the vita of Alice of Schaerbeek, Arnulf II of Ghistelles contends that the life of any holy individual has a double signification. For some, the holy woman will be 'an odor of life' ('odor vitæ') and for others, 'an odor of death' ('odor mortis'). ${ }^{153}$ Arnulf's metaphor, drawn from I Corinthians 2.15-16, is particularly apt given his subject matter. In response to Alice's extraordinary virtue, the Lord afflicts her with leprosy. ${ }^{154}$ Described in Job 18.13 as a 'firstborn death', leprosy provokes a disintegration of living bodily

153 VASEng, prol. 1; VAS, prol. 1.477. The authorship of Alice's vita is uncertain. I follow Martinus Cawley's identification of Arnulf as the work's likely author: 'Introduction [to VAS]', pp. v-xxii. For a rebuttal, see: Campion, pp. 137-39. I analyse the vita in depth in: Spencer-Hall, 'Suppurating Wounds'.

154 VAS, 2.9.479. 
tissues much like the decay to which the corpse is subject. ${ }^{155}$ Indeed, bedridden at the end of her life, Alice appears 'just like a rotting corpse' ('more cadaveris'). ${ }^{156}$ Nevertheless, the malady is a divine blessing. Like Christina Mirabilis, Alice inhabits a purgatorial body. Leprosy provides Alice with the means to expurgate all her own sin and the sins of others whilst in the mortal realm, and thus to procure her own early entrance into heaven, and a lessening of others' purgatorial torments. ${ }^{157}$ Arnulf, however, realizes that his protagonist's example is rather difficult to stomach as evidence of God's munificence. Alice reeks, quite literally, of the twin odours of life and death. How do we arrive at any unilateral interpretation of the holy woman? Death-in-life or life-in-death: it all depends on the viewer's perspective.

A similar geminate temporality structures photography, and its extension, cinema. On the one hand, the photograph crystallizes a moment out of time, locking the photographed object into an eternity. The viewer penetrates this a-chronological timescape, experiencing - if only at a remove - this temporal plenitude, an ongoing present-ness. Yet, the photograph also conjures the finality of death before the viewer's eyes. The photographed moment is gone forever. The fixed postures depicted in the image evoke the rigor mortis of death. Cinema temporarily occludes the integral mortality of the photographic image. The projector jump-starts the photogram into movement, reanimating the bodies heretofore fixed within its cell. The eternity suggested by the photograph becomes an inhabitable space on the cinema screen. But death will out in the end. The projector winds down, the moving images come to rest, and the fatalistic stasis of the photogram comes into focus once more. Again, death-in-life or life-in-death: it all depends on the viewer's perspective. How do we decide? For Arnulf, it is all a matter of attitude. By considering Alice with the firm gaze of faith, the reader will smell roses. The defensive glance of a reader thoroughly enmeshed in sin will kick up a stink. The secular modern viewer does not have the clear-cut heuristic of Catholicism with which to orient their appreciation of the photographic image. But perhaps Arnulf offers us another interpretive route. Alice, he announces, is 'the spectacle to focus on, if we are to keep an eye on ourselves and not divert our attention curiously to idle endeavours'.158 Similarly, the photographic image is a focal point for our existentialist gaze,

155 Douay-Rheims Bible. On leprosy as a living death, see in particular: P. L. Allen, pp. 25-40; Brody, pp. 6o-106.

156 VASEng, 3.31.3127; VAS, 3.31.482.

$157 V A S, 2.9 .479,3.26 .481$. For her entrance to heaven directly after death, see: ibid., 3.34.482.

158 VASEng, prol. 1. '[...] ad cujus [exemplum] intuitum nosmetipsos videamus, nec ad inania studia intentionis oculum curiosius flectamus.' VAS, prol. 1.477. 
a container into which we may channel - and ultimately work through - our anxieties about life, death, and everything in between. ${ }^{159}$

Arnulf's pronouncement also emphasizes that Alice, as with the photograph, exists to be looked at. She, along with the other Liégeoises, are visual objects that impart meaning to their followers. Above all, they are spiritually useful. This dynamic is exemplified in a scene from Christina Mirabilis' vita. After her second death, Christina is called back to life by a 'fearsomely impatient' ('impatiens agens') spiritual colleague, Beatrice. ${ }^{160}$ The nun admonishes the holy woman to return from the embrace of God in order to furnish answers to a pressing question. The text elides the specific nature of the question. Indeed, it does not really matter what the question - or answer - is. An evocation of how to reanimate Christina is far more important. The text reports Beatrice's impassioned apostrophe to the holy woman, in which Christina's obedience to the nun is underscored: 'You were ever obedient to me in life! I now therefore beseech you and admonish you earnestly [...] that you obey me even now. ${ }^{\prime 161}$ Concomitantly, Beatrice stresses the holy woman's special ability to fulfil her request, both in terms of returning to life and in relaying some special information garnered from divine insight. ${ }^{162}$ This passage thus furnishes readers with a formula, if not quite a script, to petition Christina to respond to their own calls and return to life before their own eyes - a lexical remote control to 'press play' on Christina's filmic existence. Beatrice's mix of past and present tenses - Christina was obedient, she has died, the nun is asking now - mirror the reader's own temporal relationship to the holy woman and the tense in which the reader would necessarily beg her for help. Further, the vita emphasizes Christina's 'obedience' to the needs of all Christians, both the living and the dead, and even the much maligned Jews. ${ }^{163}$ Surely, she will obediently answer the reader's requests too.

Geoffrey Batchen argues that the history of photography, as written by the academy and curated by the museum, overlooks a critical body of works: 'vernacular' photographs, snapshots of the ordinary, the sentimental, and

159 On this, see in particular: Mulvey, Death, pp. 33-53.

160 VCMEng, 52.153; VCM, 5.52.659.

161 VCMEng, 52.153. 'obediens semper mini in vita fuisti; adjuro ergo nunc te \& contestor [...] ut obedias mini etiam nunc', $V C M, 5 \cdot 5^{2.659}$.

162 VCMEng, 52.153. 'qui potens potes per illum, cui nunc jungeris, quaecumque vis, revertarisque ad vitam, \& dicas mihi, quod à te aperiendum in vita magno desiderio postulavi.' $V C M$, $5 \cdot 5^{2.659}$.

$163 V C M, 3.27 .655 ; 4.41-45.657-58$. 
those which exhibit a populist aesthetic. ${ }^{164}$ 'Vernacular' photographs, he maintains, are morphologically distinct to their 'higher class' counterparts from art photography. The latter are typically repressed into flat images, literally and metaphorically, to fit the critical framing of photographic studies and to be hung on the museum's wall. By contrast, 'vernacular' photographs extend themselves into the world. Like the holy Liégeoises, they make themselves useful. Examples of 'vernacular' photography include photographic jewellery, such as a locket which contains a photograph of a loved one, or home shrines, with clusters of photographs of family members. Such artefacts possess a 'will to narrative': they contain stories that they disclose in response to our look, as Christina discloses her divine knowledge in response to Beatrice's anxious gaze. ${ }^{16_{5}}$ Moreover, the 'vernacular photoobject' compels both haptic and visual engagement from the viewer. The album of family snapshots demands that we caress the faces of our loved ones as we turn its pages, and feel the weight of our family history when we lift it down from the shelf. 'Vernacular' photographs 'exploit the fact that the photograph is something that can also have volume, tactility, and a physical presence in the world. ${ }^{166}$ So doing, they are "thoughtful, even provocative meditations on the nature of photography in general.'

The holy Liégeoises - and their vitae - are analogous to 'vernacular photo-objects'. Analyses of the holy women's photographic properties let us disentangle the temporo-visual dynamics of photography, and hagiography. Given the fact that all the biographies are in Latin, 'vernacular' is an initially jarring descriptor. However, the texts collectively speak the 'language' of lay sanctity, of an expression of religion that appeals to normal folk as much as it is distasteful to canonization committees. There is nothing flat about these women, or the visions that they transmit to their followers: they function as 'vernacular' photographs made flesh. At every turn, their biographers urge us to turn our inner eyes upon the saints, in order to interact with them directly, dynamically, physically. A compulsion to touch - and be touched - by the divine is the hallmark of the Liégeoises' visions, and the principle foundation of their 'vernacularity'. 



\section{The Caress of the Divine Gaze}

\section{Look, and Look Again}

At the end of his Good Friday sermon in 1272 or 1273, an anonymous Parisian preacher motions towards a crucifix and invites his audience to look at Christ: "'Oh true Christian, look, look how he has his head leaning down to kiss you, his arms extended to embrace you!"' Forceful repetition of the imperative 'look' ('regarde') highlights the importance of a Christian's looking in their relationship with the Lord. A pious Christian must grasp the image initially with a look, but then caress the image with a gaze which reveals its true significance. The preacher does not address his flock in the plural, but rather with the singular 'Christian' ('chrestien'): visual adoration of Christ is a deeply personal and intimate undertaking. Stimulated by the true Christian's gaze, the viewed image/object will gesture back, enfolding the onlooker in an embrace. Given such descriptions, it is little wonder that medievalists have identified the eye as the 'privileged sense organ' of the period, with intellectual knowledge expressed again and again as a product of sight. ${ }^{2}$ At the turn of the thirteenth century, the ritual of the elevation of the Eucharist during mass was instituted. Later traditions such as Corpus Christi processions, the ringing of bells at the moment of elevation, and the popularity of monstrances led 'to an emphasis on "seeing God"' as a central worship practice. ${ }^{3}$ Nevertheless, haptic perception was central to medieval optical theories. As such, touch is ultimately the most privileged sense in the era. ${ }^{4}$

Medieval optical theories maintained that touch was integral to sight. All objects emitted species, intangible and corrupted - yet nevertheless authentic - versions of the object. For sight to occur, the species had to touch the viewer's eye and become imprinted. The species operated in two manners. In extromission, they were expelled from the object in an outwards beam. With intromission, a catalyzing beam from the viewer's eye provoked the species' trajectory backwards, towards the viewer. Roger Bacon (d. 1294), however, conjoined the two theories, and posited a model of synthesis. The

1 My translation. "Ha! Veroi chrestien, regarde, regarde, comment il a le chief encliné por toi beisier, les bras estendu por toi embrachier!"' Cited in Lipton, p. 1172, from the transcription in Bériou, pp. 787-99. The sermon appears orginally under the rubric 'Passio'in Paris, BNF, MS lat. 16482 , fols. $136^{\mathrm{r}}-141^{\mathrm{v}}$.

2 Müller, p. 206. See also: Akbari, p. 3; Denery, p. 9; Hahn, 'Visio Dei', pp. 169, 180; Starkey, p. 2.

3 B. Newman, 'Clash', p. 16. See also: Bynum, Fragmentation, p. 126; Hahn, 'Visio Dei', p. 175.

4 Hahn, 'Visio Dei', p. 180. 
viewer emitted an actualizing beam which hit the viewed object, whilst the viewed object also radiated its species to the viewer's eye. According to Bacon, both intromission and extromission were essential for sight. This synthesis destabilizes the categories of subject and object, as both the viewing and the viewer gaze at each other and touch each other with their species.

The Baconian synthesis is the theoretical scopic model which chiefly preoccupies modern medievalists in discussions of historically grounded vision. ${ }^{5}$ Bacon's theory reigned dominant in the discipline of perspectiva (optical theory) in the thirteenth century and thus is a natural object of contextualized medievalist scholarship. ${ }^{6}$ The Baconian synthesis' partial dissolution of the dichotomy of active subject and passive object, and the concomitant importance of touch to visual perception, has attracted most interest from medievalist critics. For example, Suzannah Biernoff notes that Bacon's insistence on 'physical contact' as a basis of visual perception results in the equation of looking and touching. Emma Campbell and Robert Mills articulate the same understanding of medieval vision, announcing that '[s]eeing is not so much believing as feeling', in both the physical and emotional sense. ${ }^{8}$ Much, if not all, of the recent scholarship on medieval vision is based on the analysis of differences between modern and medieval visual mechanisms. Biernoff proclaims, for instance, that 'the model of [medieval] spectatorial reciprocity' she discusses is fundamentally different 'from the now dominant formulations of the "male gaze" or "Western ocularcentrism". ${ }^{9}$ Dallas G. Denery calls for precise historical contextualization of scopic regimes, i.e. an understanding of theoretical differences and evolutions, in order to understand contemporary Western 'ocularcentrism'. ${ }^{10}$ Similarly, Kathryn Starkey maintains that studies of medieval perception produce both familiarity and alienation in the modern researcher. ${ }^{11}$

5 See, for example: Akbari; Biernoff; Campbell and Mills (eds.), Troubled Vision; Caviness; Denery; Nelson (ed.); Nichols, Kablitz, and Calhoun (eds.); Starkey and Wenzel (eds.).

6 Lindberg, Theories, p. 116. On Bacon's influence in the period, see in particular: Denery, pp. 75-115. Bacon's theories were not always easily distinguished from those of his predecessor Alhazen, from whom he drew heavily: Lindberg, Theories, p. 116; Simon. Although supporters continued to champion Bacon's optical regime in later centuries, Aristotle's intromissionist visual theories ultimately achieved dominance in the fourteenth and fifteenth centuries. On Bacon's debt to other theorists, see also brief discussion below: pp. 113-16.

7 P. 85 .

8 Emphasis in original. 'Introduction', p. 4.

9 P. 162. On Western European ocularcentrism from Plato to the present, see in particular Jay, Eyes, pp. 1-82. On anti-ocularist critique, see in particular: ibid., pp. 149-586; 'Hermeneutics'.

10 P. 9.

11 P. 2. 
In this chapter, I contend that pre-existing scholarship can benefit from consideration of a different body of modern theory when studying medieval visuality. Modern theories of embodied spectatorship posit that visual and tactile perception are central to our experiences in the movie theatre. Analyses of this strand of spectatorship theory, alongside interrogation of relevant theories of medieval looking, substantially develop the current field. This approach allows for new interpretations of modern and medieval visuality, thereby revealing linkages across temporal periods in relation to the theorization of visual economies. Existing research, on the whole, portrays medieval visuality in stark opposition to modern visual modes. This analytical program fails to profit fully from the potential for visual continuity across time periods, ways of viewing inflected in each instance by the 'cultural variability' inherent in the historical moment of viewing, but nevertheless connected. ${ }^{12}$ Moreover, critical analyses invested in pointing out what medieval sight was not often posit, implicitly or explicitly, a singular fixed form of modern visuality. As Martin Jay underscores, ocular 'domination' does not mean 'uniformity', and the mechanics of modern sight are much more complex than often imagined, or invoked. ${ }^{13}$

An acknowledgment that medieval vision entailed a haptic interchange between viewer and viewed does not nullify the overwhelming importance of the eye in the medieval sensorium. Indeed, Roger Bacon argues for the primacy of vision over all other senses in the opening to part five of his Opus majus, proclaiming that:

Vision reveals to us the differences among things, since by means of vision we experience everything in the heavens and on earth. For celestial objects are observed by means of visual instruments, as Ptolemy and other astronomers teach, as are things generated in the air, such as comets, rainbows, and the like; for their altitude above the horizon, their size, shape, and number, and everything in them are certified by means of vision aided by instruments. Through vision we also experience things here on earth, for concerning this world the blind can have no experience worthy of the name. ${ }^{14}$

12 Jay, Eyes, p. 9.

13 Ibid., p. 45 .

14 Lindberg (ed.), Perspectiva, 1.1.1.3. References to the Opus majus (English and Latin) are in the form of part, distinction, chapter, page number. See also: Lindberg's brief discussion of this chapter (ibid., pp. xx-xxi) and Frankowska-Terlecka's comments on Bacon's privileging of vision above all other senses (pp. 214-15). 'quod visus solus ostendit nobis rerum differentias: per illum enim exquirimus certas experientias omnium quae in coelis sunt et in terra. Nam 
Bacon dismisses the other senses: the senses of smell and touch are brutish and thus not suited to 'human dignity' ('dignitatem sapientiae humanae'), whilst hearing does not allow for individual experiential testing of beliefs..$^{15}$ Further, since a separate scientific discipline has been created for the purposes of studying vision ('perspectiva'), it follows that visual perception is of particular utility to scholars. For Bacon, the superiority of vision lies in the sense's route to truths about the mortal world, an expression of an ocularcentrist attitude which chimes with later thinking in Enlightenment empiricism. ${ }^{16}$ However, Bacon's ocularcentrism must also be nuanced: it was also founded on the belief that the study of optics reveals religious truths. ${ }^{17}$ As Dominique Raynaud formulates, 'optics would allow access to the Creator through knowledge of the created world'. ${ }^{18} \mathrm{Clearly}$, this is an important break from modern notions of vision as the route to empirical secular knowledge.

For Campbell and Mills, the significance of Bacon's optical theories lies in the unpacking of the association of power with the male gaze, and passivity with the female gaze, thereby revealing new readings of 'medieval gender'. ${ }^{19}$ Medieval vision 'troubles' the modern spectatorial dichotomy of active (masculine) and passive (feminine) as the spectator occupies both positions in the visual act. Such readings chime extraordinarily well with modern theories of embodied cinematic spectatorship. Vivian Carol Sobchack posits that the cinematic spectator evinces 'a carnal interest and investment in being both "here" and "there", in being able both to sense and to be sensible, to be both the subject and the object of tactile desire. ${ }^{20}$ Seeing an onscreen body opens the spectator to becoming the body on screen, feeling both the bodies portrayed onscreen and their fleshly, fixed offscreen body as their own. The spectator is thus "doubly situated". ${ }^{21}$ Rigid definitions of onscreen and offscreen reality, and the subject/object demarcation crumble via visual encounters in the cinema. As Laura U. Marks asserts, such theories

ea quae in coelestibus sunt considerantur per instrumenta visualia, ut Ptolemaeus et caeteri docent astronomi. Et similiter ea quae in aere generantur, sicut cometae et irides et hujusmodi. Nam altitudo earum super horizonta, et magnitudo, et figura, et multitudo, et omnia quae in eis sunt, certificantur per modos videndi in instrumentis. Quae vero hic in terra sunt experimur per visum, quia caecus nihil potest de hoc mundo quod dignum sit experiri.' Bridges (ed.), II, 5.1.1.2.

15 Lindberg (ed.), Perspectiva, 1.1.1.5; Bridges (ed.), II, 5.1.1.2-3.

16 Jay, Eyes, pp. 83-148; Lauwrens.

17 Bridges (ed.), III, 2.1.36. On this, see also: Lindberg, 'Medieval Science'; Raynaud, pp. 738-40.

18 P. 738; my translation. 'Loptique permettrait d'accéder au Créateur par la connaissance du monde créé'.

19 Campbell and Mills, 'Introduction', p. 4. See also: Biernoff, p. 134.

20 Emphases in original; Carnal Thoughts, p. 66.

21 Barker, p. 84 . 
of cinematic somatism, i.e. the enmeshment of the body in the visual act, rest upon the notion of 'a mutual permeability and mutual creation of self and other, ${ }^{22}$ Within this interpretive framework of cinematic spectatorship, 'the characterization of the film viewer as passive, vicarious, or projective must be replaced with a model of a viewer who participates in the production of the cinematic experience. ${ }^{23}$ As Bacon's synthesis theory asserts the interconnection of sight and touch, and the problematization of subject/ object distinctions, so too do modern theories of cinematic somatism. Such modern formulations of spectatorship, almost entirely overlooked by medievalist critics to date, offer fertile tools with which to examine, and unpack, medieval divine visions from a fresh perspective. In what ways can material from each side of the temporal divide inform us about visual praxes and the body's implication in viewing? Where does such a comparison falter, and what can that tell us?

Films also touch us affectively. ${ }^{24}$ For example, Raymond Bellour's primary material for his monograph analysing cinema spectatorship, Le Corps $d u$ cinéma (The Body of Cinema), consists of the films which 'touched' him in some way ('chaque film qui m'a touché'). ${ }^{25}$ Bellour details how watching the repeated motif of two young boys on a bicycle in Displaced Person (Daniel Eisenberg, 1981) suddenly brought back the buried recollection of the tandem bicycle his parents used during the Occupation. ${ }^{26}$ Indeed, a large part of Bellour's book interrogates cinematic spectatorship in terms of emotion. The author argues that emotion is constitutive of the 'body of cinema' ('corps du cinéma'), alongside hypnosis and animality. ${ }^{27}$ Christiane Voss argues similarly that 'affective entanglement' is central to the structure of cinematic spectatorship, predicated on illusion formation. ${ }^{28}$ In this chapter, then, 'tactile' does not solely refer to the physical sensation of touch, but also more broadly to 'feeling', as in emotional sensibility.

With the neologism 'cinesthesia' - cinema, synaesthesia, coenaesthesia - Sobchack brings together the core of her thesis. ${ }^{29}$ Cinema is founded on

22 Skin, p. 149. Marks refers here to a different work: Sobchack, Address. Nevertheless, her comments are equally applicable to Sobchack's theories from the later work which I discuss here.

23 Marks, Skin, pp. 149-50.

24 On this, see in particular Dalmasso, 'Toucher', p. 74; 'Voir', p. 119; Marks, Touch, p. 191.

25 P. 17.

26 Pp. 225-27.

27 P. 13. For emotion section, see pp. 129-412.

28 P. 139.

29 Sobchack, Carnal Thoughts, pp. 53-84, in particular p. 67 . 
synaesthetic experience, the transposition of visual into tactile perception, with the physical grasp of individual sensory experiences portrayed visually onscreen felt in the moviegoer's offscreen body. In an essay published in 1991, Linda Williams, for example, draws attention to the 'physical jolt[s]' produced in the moviegoer's body by what she terms '"gross genres"', films which feature 'heavy doses of sex, violence, and emotion' - pornography, horror, and sentimental weepies. ${ }^{30}$ By focusing on the physical reactions of bodies on screen - from explicit depictions of gore and violent destruction to more subtle psychological stress - horror 'assault[s] and agitate[s] the bodies of the audience'. ${ }^{31}$ Such physical effects of fear in the audience are measurable, and tests have shown increases in heart rate, skin temperature, and blood temperature in horror viewers both in the short and long term after exposure to the film..$^{32}$ Sobchack moves beyond generic bounds, arguing that all films provoke physical sensation in the spectator's body via the visual faculty. Further, such corporeal reactions bring the spectator back to their own body as a sensory being, an acknowledgment of the totality of their sensory experience (coenaesthesia). The film spectator is thus always a 'cinesthetic subject'. 33

In this chapter, I deploy medieval optical theories to reveal medieval sensory responses, in order to examine the medieval mystical viewer as a 'cinesthetic subject'. Parallels between Sobchack's schema and instances of haptic viewing in medieval hagiography are fleshed out, and differences interrogated in the formulation of a particularly medieval cinesthesia. Holy women fuse with the divine object of their visions, a process which destabilizes seemingly fixed labels of active and passive, viewer and viewed. In these episodes, God is posited as a projector of light, the originator of all authentic vision. Above all, vision leads to feeling, not just for the holy woman who sees God herself, but also for the onlookers who gaze upon her. Such analyses of medieval tactile visuality ultimately bring us back to the feelings of the modern body, the contemporary moviegoer and, indeed, the academic scholar. Episodes of haptic visuality do not only occur in the space of the cinema theatre. Rather, such experiences can also be found in, and are stimulated by, written texts, particularly those invoking visions. By consequence, a new methodology for theorizing the haptic interplay between readers from modern and medieval eras, mediated by the manuscript, is 
revealed. Before embarking upon this interrogation, however, a thorough grounding in the precise mechanics of Bacon's medieval optical schema is needed. It is to this undertaking that I now turn.

\section{Bacon's Synthesis Theory}

The basic component of Bacon's optical theory of synthesis is the species, a concept with roots in the Neoplatonic principle of emanation, in which all things radiate their inherent power externally. ${ }^{34}$ In his reliance on the doctrine of the multiplication of species, Bacon follows and expands the earlier work of Robert Grosseteste (d. 1253). The latter had set forth the basic principles of this theory in his text De lineis, angulis et figuris, written c.1230-1235. Using a series of negations, Bacon defines species as follows:

But a species is not body, nor is it moved as a whole from one place to another; but that which is produced [by an object] in the first part of the air is not separated from that part, since form cannot be separated from the matter in which it is unless it should be mind [also soul; anima]; rather, it produces a likeness to itself in the second part of the air, and so on. Therefore there is no change of place, but a generation multiplied through the different parts of the medium; $[\ldots . .]^{35}$

The species is identical to that from which it is emitted in all aspects, apart from in dimension. It travels through a medium, such as air, in the manner of a wave, reproducing itself again and again, maintaining contact at all times with the originary object, until it reaches its target (the eye). Bacon's reference to the soul ('anima') as the unique example of form isolated from matter shows his commitment to following Aristotle's 'form-matter dichotomy', and the Aristotelian theory of the soul as the form ('forma') of the material body. ${ }^{36} \mathrm{By}$ stressing that the object's form is never separated from its matter, Bacon paradoxically allows for cogitation on the troubling

34 Lindberg, 'Alhazen's Theory', pp. 335-36.

35 Translation from E. Grant (ed.), p. 394, cited in Lindberg, Theories, p. 113. 'Sed species non est corpus, neque mutatur secundum se totam ab uno loco in alium, sed illa quae in prima parte aeris fit non separatur ab illa, cum forma non potest separari a materia in qua est, nisi sit anima, sed facit sibi simile in secundam partem,et sic ultra. Et ideo non est motus localis, sed est generatio multiplicata per diversas partes medii; [...]'. Bridges (ed.), II, 5.9.4.71-72. Bacon also expounds on species in De multiplicatione specierum: ibid., II, 1.3.433-38.

36 Lindberg, Theories, p. 114. 
possibility of the reverse: an object's possession of some form of 'soul', a 'forma' separate from its matter.

Returning to Bacon's text, the perspectivist proclaims that various terms used by fellow optical theorists are actually synonymous with the term 'species', including 'lumen', 'idolum', 'phantasma', 'simulacrum', 'forma', 'intentio', 'similitudo agentis', 'umbra philosophorum', 'virtus', 'impressio', and 'passio'. ${ }^{37}$ When Alhazen uses the term 'forma', Aristotle employs 'idolum', or Avicenna refers to 'lux' in their theories, the scholars actually mean 'species', Bacon maintains. This systematic relabelling permits Bacon to assert that all other perspectivists are in agreement with his own theories. ${ }^{38}$ According to Bacon, the visual species is, in fact, only one form of species, and the term denotes, more generally, the 'effect of an agent':

Every efficient cause acts through its own power, which it exercises on the adjacent matter, as the light [lux] of the sun exercises its power on the air (which power is light [lumen] diffused through the whole world from the solar light [lux]). And this power is called 'likeness', 'image', and 'species' and is designated by many other names, and it is produced both by substance and by accident, spiritual and corporeal. [...] This species produces every action in the world, for it acts on sense, on the intellect, and on all matter of the world for the generation of things. ${ }^{39}$

Bacon's study of visual species, then, is a worthwhile investigation into the underlying mechanics of the universe. An analysis of visual species will contribute significantly to the comprehension of the behaviour of other species, which govern all aspects of the world.

Although Bacon argues that all perspectivists are essentially in agreement with him, the majority of his theories on the mechanics of vision are indebted to the works of Arab scientist and intromissionist Alhazen (d. c. 1039; also known as Ibn al-Haitham). Alhazen's work Kitāb al-manāzir was translated into Latin in the twelfth or early thirteenth century as De

39 Translation from ibid., p. 113; citing from E. Grant (ed.), p. 393. 'Omne enim efficiens agit per suam virtutem quam facit in materiam subjectam, ut lux solis facit suam virtutem in aere, quae est lumen diffusum per totum mundum a luce solari. Et haec virtus vocatur similitudo, et imago, et species et multis nominibus, et hanc facit tam substantia quam accidens, et tam spiritualis quam corporalis. [...] Et haec species facit omnem operationem hujus mundi; nam operatur in sensum, in intellectum, et in totam mundi materiam per rerum generationem'. Bridges (ed.), I, 4.2.1.111. 
aspectibus or Perspectiva and became hugely influential in the Western world. ${ }^{40}$ After translating Alhazen's 'forma' as 'species', allocating to the latter all of the properties of the former, Bacon follows Alhazen's geometrical theories of the mechanics of vision closely. Each part of the eye forms the apex of a triangle, and the baseline of each triangle is formed by a specific part of the viewed object from which species are emitted, as illustrated in Fig. 6. ${ }^{41}$ Vision takes place when the cones of species from an object (Fig. 6: MP) penetrate the viewer's eye (apex at A), and are arranged on the surface of the anterior glacial humour $(\mathrm{GF}) .^{42}$ The species, first refracted at the crystalline lens $(\mathrm{Q}$ and $\mathrm{V}$; the rear membrane of the anterior glacial humour), then travel through the vitreous humour to the optic nerve (C), where species from the two eyes are conjoined, and a judgement on the visual input can finally be made. ${ }^{43}$ The angle travelled by the ray of species to the eye accounts for the strength of the image received. Perpendicular rays carry the most power, as in Fig. 6, whilst those of other angles may result in weak or even imperceptible images. Bacon diverges from Alhazen, however, in his thesis that the intromission of species from the viewed object alone is not sufficient to enable vision. Instead, he asserts that extromission of species from the eye is also necessary, and it is the mechanism of both extromission and intromission that allows visual perception.

Bacon bases the extromissionist part of his synthesis theory on two key propositions. Firstly, the doctrine of the multiplication of species set forth by Grosseteste maintains that all things produce species and thereby effect actions. Thus, it is logical that eyes too emit species that enable visual perception. ${ }^{44} \mathrm{He}$ argues that the existence of ocular species is further proved by the fact that the eye can be seen in a mirror. ${ }^{45}$ Despite the fact that Bacon here confuses the ocular species (that which allows the eye to be seen) and the visual or object species (via which the eye sees), his position is quite clear. ${ }^{46}$ Bacon's second line of argument relates to the relative lack of nobility of the object species (those issued from the viewed object). He

40 Risner (ed.). For an overview of the work and the scholar, see in particular: Lindberg, 'Alhazen's Theory'; Theories, pp. 58-86. For Bacon's debt to Alhazen, see: Theories, pp. 109-15.

41 Bridges (ed.), II, 5.6.1.35; Lindberg, Theories, pp. 109-11; Nichols, pp. 290-91. Fig 6 is derived from the illustration found originally in Collection of Texts on Astronomy, London, BL, MS Harley 8 o, fol. $8^{\text {r. }}$

42 Bridges (ed.), II, 5.6.1.35.

43 Ibid., II, $5 \cdot 5 \cdot 2 \cdot 32-33 ; 5 \cdot 7 \cdot 1 \cdot 47-49$.

44 Ibid., II, 5.7.4.52.

45 Ibid., II, 5.7.2.49.

46 Lindberg, Theories, pp. 114-15. 
Figure 6 Radiation through the glacial (or crystalline) humour according to Roger Bacon

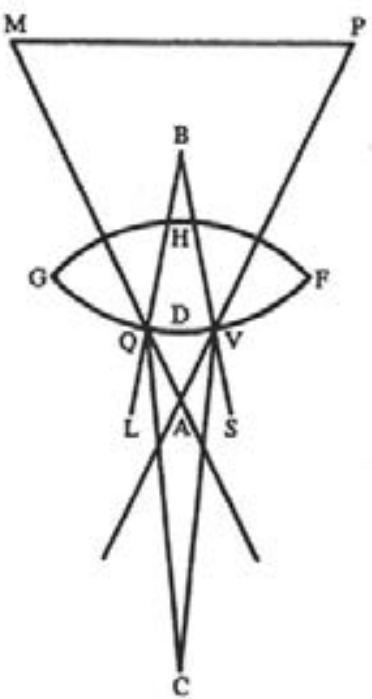

Reproduced with permission of the University of Chicago Press, from David C. Lindberg, Theories of Vision from al-Kindi to Kepler (Chicago: University of Chicago Press, 1976), p. 110

opines that inanimate object species require activating by the more noble ocular species to allow for vision to occur. ${ }^{47}$ Although Bacon demonstrates the necessity of the reciprocal intromission/extromission action, he is quite clear on the separation of ocular species from object species. The two forms of species never become united, despite their common inhabitation of the medium of air. Further, the two can be differentiated: object species have colour and light, whilst ocular species do not.

There is, Bacon declares, 'no comparison' ('non habet comparationem') between the two types of species as ocular species possess the power of the soul, and object species do not. The (modern) notion of a fundamental power imbalance between an active viewer and a passive viewed object is not left by the wayside altogether. There is a hierarchy of agency between the viewing subject and the inanimate viewed object. The latter possesses agency only in latent form, due to its incompatibility with the superior viewing subject and its species. Though the viewed object emits species, it needs the viewing subject for sight to occur. Two inanimate objects could 
not, for example, 'see' each other, nor could a human viewer receive images somehow against their will. Bacon's model is thus based on a hierarchical regime with embedded concepts of activity and passivity. Though the viewed object can be active, this activity cannot be provoked without the superior agency of the viewing subject. An analogous experience to the haptic interplay between viewing subject and viewed object can be found in the interaction of human with machine. For example, a woman touches a machine, switches it on, and then is bodily affected by the machine's 'activity', perhaps the vibrations of a massage chair. Yet, this machine activity originates in the initial human caress of a finger over the 'on' switch, and has no vital essence itself.

Nevertheless, Bacon's insistence on the innate superiority of the viewed subject's species does not foreclose an interpretation of the troubling haptic dynamism of medieval visuality. A crucial element of Bacon's optics remains unchanged: a viewer touches and is touched by, indeed internalizes, the object of his vision. The tactile element of this interchange is not just metaphorical or analogous, as species of corporeal things are unequivocally material forms according to Bacon..$^{48}$ Thus, the viewer's eye has a haptic interaction with a material element in the visual act. Indeed, Bacon proclaims that it is madness ('insania') to think otherwise. ${ }^{49}$ Moreover, the viewed object's dynamism is integral to vision, though this dynamism is inferior to that of the viewing subject.

Robert Folger maintains that Bacon's proclamations of the exigency of extromission are derived from anxiety due to 'the problem of the precarious status of agency and free will in the intromission model'..$^{\circ}$ From this perspective, extromission functions as a bulwark against the potentially total dissolution of subject/object categories, a dissolution which is clearly destabilizing. By attempting to shore up the subject's ultimate agency in visuality via extromission, Bacon paradoxically reveals that this superior agency is in some way endangered by the act of vision. Discussions regarding the ennobling required by object species examined above spare scenarios in which the viewed object is itself a viewing subject, such as when two people look at each other. What happens when the viewed object is of precisely the same nobility as the viewing subject? In this instance, why would extromission be necessary, apart from to cloak the unsettling experience of sight achieved wholly due to the agency of the viewed object? In the following 
section, I unpack the complexities of an individual gazing at an object that is simultaneously a subject: what happens when a holy woman looks at God.

\section{Becoming What You See: The Cinesthetic Subject}

For medieval visionaries, to see was not just to 'become similar to one's object' as Biernoff asserts..$^{1}$ Rather the aim of religious vision was to fuse entirely with one's object, God Himself: touching and being touched in a single glance as an extreme form of Sobchack's formulation of cinesthesia. This haptic interplay ultimately renders subject/object labels irrelevant. The spectator becomes object of the gaze, as the conventional object (film/ screen) accesses subjectivity. This is borne out in hagiographic texts in which Christ and a saint meld in moments of mutual visual perception. Beatrice of Nazareth, for example, looks upon the crucifix and meditates upon Christ's broken body. The Christ she sees is 'pierced through, bloody and hanging on the cross' ('confossum et cruentum in cruce pendentem'). ${ }^{52}$ The focus of her vision is the denigrated physicality of the son of God, 'his stripes and wounds' ('illius plagis atque vvlneribus'). This concentration leads to union between the woman and Christ: 'her whole soul, melting with the fire of compassion [compassionis] like wax [cera] melting before the fire, flowed totally into the chalice of Christ's wounds [in calice Christi]'. ${ }^{53}$ This scene is a moment of penetration as Beatrice's soul is literally internalized by Christ, taken up through his bloody wounds. The repetition of 'c' here highlights the means by which Beatrice achieves divine union ('compassionis') and the intermingling of her soul (as wax, 'cera') with Christ's materiality, the blood contained within the chalice of his body ('in calice Christi'). Christ's body, similarly, penetrates Beatrice's body, and remains implanted in her own heart even after the ecstasy ceases: 'Thus devoutly keeping his memory in mind by meditation, she did not let it depart from her heart through forgetfulness. 54

Juliana of Mont-Cornillon is also obsessed with the image of a suffering Christ on the crucifix. As with Beatrice, this image is impressed within her very heart:

$51 \quad$ P. 137.

$52 \quad V B N, 2.6 .109 \cdot 134-35$.

53 Ibid., 2.6.109.135. 'quasi cera liquescens a facie ignis., ita, compassionis igne liquefacta, illius anima tota simul in calice Christi vvlnerum emanauit'. Ibid., 2.6.109.134.

54 Ibid., 2.6.109.135. 'ita deuote, meditationis intuitu, illius memoriam in mente retinens:, per obliuionis obstaculum hanc a corde suo recedere non permisit'. Ibid., 2.6.109.134. 
These marks of the suffering and dying Christ were ever present to Juliana's heart. [...] The memory of them had given her a heart of flesh [Ezekiel 11.19], so tender that for a long time, she could neither hear anyone speak of Christ's Passion nor speak of it herself, without suddenly feeling an incredible pain in her heart, caused by her extreme compassion. ${ }^{55}$

Seeing Christ's torments pierces Juliana's own heart, not just momentarily but whenever she is reminded of the Crucifixion. Christ's flesh incorporated within her body is not dead, but lives on as part of Juliana and continues to suffer. In Ezekiel 11.19, to which the above description implicitly refers, God declares: 'And I will give them one heart, and will put a new spirit in their bowels: and I will take away the stony heart out of their flesh, and will give them a heart of flesh', ${ }^{6}$ All of humanity is given but one heart by the Lord; all devout believers share the same heart, that of God Himself. Thanks to the Incarnation, the Lord's fleshly heart is literally to be found in the corporealized container of his spirit, Christ. As Juliana takes Christ into her heart, she internalizes God and all of His creation. During rapture, the saint remains an individual (a feeling 'I', with her own heart) but also part of the plural majesty of God's divinity (part of a divine 'one'). Juliana exists both in God and alone. Moreover, this parallel operation of subjectivity and collectivity is shown to be a central tenet of Christianity: consubstantiality.

The preoccupation with complete union and the demolition of the boundary between subject and object is not just evident in religious vision(s), and the parallel experience of cinematic cinesthesia. Juliana's biographer expounds at length on the saint's divine visions which show the veracity, if not clearly the mechanics, of the Trinity:

With the eyes of a pure heart, therefore, she contemplated [contemplabatur] the Trinity in Unity and Unity in Trinity [Trinitatem in Unitate, \& Unitatem in Trinitate]: three with respect to the persons and one in its simple substance, essence, nature [in simplici substantia, essentia, natura]. She beheld [intuebatur], and in beholding marvelled, how that divine being does not refuse division in persons, although in its most simple substance, essence [in sua simplicissima substantia, essentia,

55 VJCEng, 1.4.18.205. 'Haec patientis \& morientis Christi insignia cordi Julianae semper fuere praesentia. [...] quorum memoriâ tam carneum ac tenerum cor sibimet confecerat, ut multo tempore nec aliquam personam audire loquentem, nec ipsa loqui de Christi passione poterat, quin prae nimia compassione ad dolorem cordis incredibilem ipsa moveretur.' VJC, 1.4.18.450. 56 Douay-Rheims Bible. 
natura], and nature it admits no partition. She saw [videbat] how that supreme Deity, in the Incarnation of the Father's only begotten Son, descended wholly to earth yet nevertheless remained wholly in heaven. She saw [videbat] the blessed spirits and the souls of the saints - how they existed in themselves and how in God, and how God was in them [quomodo erant in seipsis, quomodo in Deo, \& quomodo Deus erat in illis]. She saw [videbat] how Christ shows himself whole, unbroken, and perfect [se totum integrum, \& perfectum exhibet] in the bread to everyone who receives him unto salvation. Nevertheless, she saw [videbat] that he remains unbroken and perfect [integrum \& perfectum] in himself. ${ }^{57}$

The concept of a divided yet fully coherent whole is difficult to grasp, shown by the length of exposition here. Nevertheless, the repetition of verbs of visual perception ('contemplabatur', 'intuebatur', and four instances of 'videbat') reinforce the authenticity of the doctrine. The shift from deponent verbs in imperfect passive form ('contemplabatur', 'intuebatur') to active verbs in the imperfect ('videbat') underlines the shift from general comprehension to direct understanding of the divine program, which Juliana gains via her visual faculty. Mere contemplation gives way to seeing, and seeing leads to authentic understanding.

A variety of stylistic devices are deployed in the passage to emphasize the unity of God and His flock, allowing the reader to 'see' lexically (or read) what Juliana sees directly in her vision. The chiasmus 'the Trinity in Unity and Unity in Trinity' ('Trinitatem in Unitate, \& Unitatem in Trinitate') syntactically represents the interlinking of individual parts (Trinity) in a whole (the Unity of God) which ultimately forms one entity (the chiasmus). The author balances concepts traditionally comprehended as opposites, rendering them complementary according to Christian doctrine. For example, Christ inhabits both the mortal and heavenly realm fully ("tota descendit in terris [...] tota remansit in caelis'). Repetition similarly highlights the intertwining of elemental parts and whole. The insistent usage of 'quomodo' simultaneously

57 VJCEng. 1.4.20.207. 'Contemplabatur igitur mundi cordis oculis Trinitatem in Unitate, \& Unitatem in Trinitate: Trinitatem in Personarum proprietate, Unitatem in simplici substantia, essentia, natura. Intuebatur, \& in suo intuiti mirabatur, quomodo illa Deitas in Personis non abnuit divisionem, quae in sua simplicissima substantia, essentia, natura, nullam recipit sectionem. Videbat quomodo illa summa Deitas, incarnatione unigeniti Patris, tota descendit in terris: \& nihilominus tota remansit in caelis. Videbat beatos Spiritus, nec non \& Sanctorum animas, quomodo errant in seipsis, quomodo in Deo, \& quomodo Deus erat in illis. Videbat quomodo Christus singulis se sumentibus in salutem, se totum, integrum, \& perfectum exhibet in cibum; quem nihilominus in semetipso remanere videbat integrum \& perfectum.' $V J C, \mathbf{1 . 4 . 2 0 . 4 5 1 .}$ 
isolates particular attributes of the saints and conjoins them. Christ is shown to be eternally perfect and whole ('integrum \& perfectum'), no matter which corporeal form he takes - the Eucharistic wafer, or a human body. Moreover, the author emphasizes the purity of Juliana's heart and intelligence ('sibi prae excellenti mentis puritate \& corporis sanctitate saepissime'), which allow her authoritative knowledge direct from God. Though the lay audience may not understand how this system works, the need to believe in the doctrine laid out in this vision is vehemently underlined. Juliana, after all, has been taught by God Himself ('illo docente qui docet hominem scientiam') and has no need to educate herself with mortal texts. Her staunch faith in the doctrine of the Trinity allows her to escape any heretical traps set in her path, and enables her to live a life of perfect devotion.

The sequence of images upon which Juliana focuses, and which facilitate her rapture, feature an abject Christ:

She saw him bound, scourged, spat upon, provoked with mockery, pierced with nails. She saw him as the brazen serpent lifted high on the rod of the Cross in the desert of this exile [John 3.14; Numbers 21.9], given myrrh for his drink [Mark 15.23], his side pierced by the lance [John 19.34]..$^{8}$

(Adspiciebat ligatum, flagellatum, consputum, opprobriis lacessitum, clavis confixum[.] Aspiciebat illum serpentem aeneum, in hujus exilii deserto super crucis stipitem exaltatum, myrrha potatum, latus lancea perforatum. $)^{59}$

The punctuation and percussive repetition of '-um' at the end of seven of the verbal clauses builds an inescapable rhythm. This externally issued compulsion to look is reinforced by the repetition of Juliana's own look: 'Adspiciebat [...] [a]spiciebat'. She looks and looks again, and so too must the text's audience, as a cinema spectator must follow the gaze of the filmmaker recorded by the camera. Juliana's look, the narrator's, and the reader's look intermingle to penetrate the interstices of Christ's body, and the subject of the verb 'to see' shifts implicitly from 'she' to 'I'. To borrow from Barbara Newman's discussion of medieval meditation manuals, 'the boundary between "I visualized" and "I saw" is porous indeed. ${ }^{60}$ The sequence of verbs, loaded upon one another, forces the gaze to travel from one image to another, travelling 
in both space and time, and leads to an intense kinaesthetic effect. This experience is mediated textually and narratively, unlike shifts in cinematic shots, which force the spectator's gaze to follow quite literally the camera's movements. Nevertheless, it mimics the cinematic form with potency.

\section{God the Projector}

The image of Christ with which Beatrice, Juliana, and others interact in visions - the film projected onto the spiritual cinema screen - comes directly from the Incarnation, God's choice to give His son to the world, to project His divinity in a visible realm on earth. God functions as part of the cinematic apparatus: as a cinema projector, the projectionist, and the light emitted from the cinema projector (the intangible material of the film). Saints' vitae not only reveal God's reality by depicting divine visions, in which God is visible and tangible as Christ, but also expose the mechanics of vision to a text's audience and to onlookers within the diegesis. ${ }^{61}$ The beam of 'actualizing' ocular species which ennoble the species of viewed objects is made visible in the vita of Beatrice of Nazareth: 'From the fire of love with which she was burning inside, a spiritual fire also rose to her physical eyes, and from both her eyes it emitted a ray of wonderful brightness [radium mire claritatis] for those sitting around her to see. ${ }^{62}$ Beatrice struggles to discern items of the mortal world with such rays emanating from her eyes. Her gaze is pulled towards the divine cinema screen to the detriment of her ability to see events outside of the cinema theatre in which the screen is housed. Nevertheless, the light emitted is extraordinarily powerful. The light consists of a 'heavenly clarity' ('celesti claritate') with which Beatrice 'penetrated [penetrauit], with the marvellous keenness of contemplation [contemplationis], things both visible and invisible, corporal [corporalia] and spiritual.' ${ }^{63}$ The alliteration of ' $c$ ' in this sentence ('celesti claritate', 'corporalia', 'contemplationis') phonically and visually links the elements required to procure exemplary vision. Devout contemplation of the Lord's majesty allows the viewer to see with the aid of the heavenly light of pure

$61 \quad$ Neaman, p. 28.

$62 V B N, 3.13 .241 .281$. 'Siquidem ex caritatis incendio quo cremabatur intrinsecus, etiam ad corporales oculos ignis spiritualis ascendit:, qui ex vtroque radium mire claritatis ad aspectum omnium circumsedentium foras emisit.' Ibid., 3.13.241.280. For similar descriptions of ocular beams shining from a holy woman's eyes, see: VILéau, 6.57.123; VILov, 3.4.22.188.

63 Ibid., 3.13.241.283. 'nichilominus tamen, in illa celesti claritate, tam visibilia quam inuisibilia, tam corporalia quam spiritualia, mirabili contemplationis acie penetrauit'. Ibid., 3.13.241.282. 
perception. Such vision allows true understanding not just of spiritual items, but corporeal (worldly) things too - and can occur via the saint's bodily eyes. Additionally, the 'penetration' suggests, as in Bacon's theories, a physical enmeshment of Beatrice with the objects of her vision.

The cause of the saint's ocular beams, we are told, is the 'fire of love' ('caritatis incendio') she has for Christ: her exemplary piety and devotion to the Lord. ${ }^{64}$ It is Beatrice's staunch faith which makes her ocular species so adept at perception. This passage overtly depicts a moment of extromission, with species being expelled from the holy woman. But the text also describes intromission, as the saint is shown to have a mystical beam of light shining on her face. The source of this introjective light is God Himself, a result of Him looking at the saint directly, which ultimately shores up Beatrice's faith and creates the 'fire of love' with which she burns. Beatrice is seen by God (intromission ray) and thus can see not just mortal, but all spiritual things, including God Himself (extromission ray). As Beatrice sees God seeing her, she is able to see God. The act of visual perception is mutually constitutive: God's authenticity is revealed and shored up, whilst Beatrice is pushed back into the felt experience of her body. Sobchack encapsulates this process:

As we watch this expressive projection of an 'other's' experience [images on the cinema screen], we, too express our perceptive experience. Through the address of our own vision, we speak back to the cinematic expression before us, using a visual language that is also tactile, that takes hold of and actively grasps the perceptual expression, the seeing, the direct experience of that anonymously present, sensing and sentient 'other'. ${ }^{6}$

The passage which depicts outward-directed light from God in Beatrice's vita links the saint with the biblical figure of Moses:

Anyone who was to examine the wonderful brightness shining on the faces of both the humble Beatrice and of Moses, the chosen servant of God to whom the Lord spoke face to face and whose face seemed to have horns because of its brightness, will very rightly compare the two in regard to its merit of election as well. ${ }^{66}$

64 Ibid., 3.13.241.280-82.

65 Address, p. 9 .

$66 V B N, 3.13 .241 .281$. 'humilem beatricem electo dei famulo moysi, cui locutus est dominus facie ad faciem, pre claritate vvltus sui cornutam faciem pretendenti., quisquis vtriusque mirabilem vvltus claritatem inspexerit, quo-ad electionis meritum aptissime comparabit'. Ibid., 3.13.241.280. 
Moses appeared as if horned to onlookers after speaking to God and receiving the Ten Commandments (Exodus 34.27-35). The horns were, in fact, beams of light pouring forth from his face. Once Moses realizes his appearance, he covers his face with a veil (a screen which obscures sight) whenever speaking to others. In the chapter from Beatrice's biography, however, onlookers are shown to look upon the shining faces of Moses and the holy woman, and bathe in divine light. Yet in Exodus 33.18-23, God speaks to Moses and affirms the impossibility of a mortal man seeing His face:

And he said: shew me thy glory. He answered: I will shew thee all good, and I will proclaim in the name of the Lord before thee: and I will have mercy on whom I will, and I will be merciful to whom it shall please me. And again he said: Thou canst not see my face: for man shall not see me and live. And again he said: Behold there is a place with me, and thou shalt stand upon the rock. And when my glory shall pass, I will set thee in a hole of the rock, and protect thee with my right hand, till I pass: And I will take away my hand, and thou shalt see my back parts: but my face thou canst not see. ${ }^{67}$

It is through the intromitted divine rays directed at Beatrice and Moses that onlookers, and indeed the text's audience, see God Himself - albeit in the form of light, and not as a physicalized man here. The 'back parts' which God permits Christians to see resonates with the conceptualization of Beatrice as screen. The prohibition of a direct vision of God is upheld, but also circumnavigated. It is this divine light issuing to the holy individuals that is the object of extromitted rays, issuing from onlookers as they see the beams shining forth from Beatrice's eyes. In order to be able to see these beams, interpenetration must occur between the beams and the onlookers' eyes. Thus, the onlooker too internalizes God's grace, although in a secondary and less direct form than that experienced by a truly holy individual.

Beatrice functions as a secondary screen upon which God's light is projected, and as a secondary projector which pours forth light refracted from the primary projector, thereby enabling her devotees to see. This chimes with Bacon's analogies of the reception of light rays as the reception

67 Douay-Rheims Bible. On the significance of this biblical sequence as evidence of the importance of vision for spiritual revelations, see: Akbari, p. 4. For instances of God's gaze directed at Christians, see: Hebrews 4. 12-13, Jeremiah 16. 17, Job 34. 21, Proverbs 5. 21, 15. 3, Psalms 32.13. 
of divine grace. Bacon declares: 'Since the infusion of grace is supremely illustrated by the multiplication of light, it is useful in every way that by the multiplications of corporeal light should be revealed to us the properties of grace in the good and the rejection of it by the wicked. ${ }^{68}$ He avers that good men receive grace directly and perpendicularly, without any refraction or reflection ('luci directe incidenti et perpendiculari [...] non reflectunt a se gratiam, nec frangunt'). Good, but imperfect men receive 'refracted' grace ('luci fractae'), as their faults cause grace to be deflected. Sinners, however, reflect grace altogether due to their lack of virtue ('reflectunt et repellunt a se gratiam Dei [...] comparatur luci repulsae seu reflexae'). ${ }^{69}$ In Beatrice's vita, this analogy is rendered concrete. Furthermore, Voss postulates that a 'second screen' is necessary for modern film theorists to unpack the exchanges at play between the spectator and the film screen. ${ }^{70}$ Watching this postulated secondary screen allows for 'the osmotic exchange between the so-called spectator and the events on the primary screen [to become] visible'. The medieval example of Beatrice's function as secondary screen offers similar rewards, allowing insight into the mechanics of tactile visuality, both medieval and modern.

Extreme clarity of ocular species allows a holy woman to experience the earthly world as a representation of the Lord - or, in other words, to inhabit the religious experience as both onscreen and offscreen, contemplative and evident in the corporeal world. She, like the Sobchackian cinesthetic subject, is 'able to experience the movie as both here and there rather than clearly locating the site of cinematic experience as onscreen or offscreen'. ${ }^{71}$ If gazed at with pious eyes, all earthly artefacts, even the most mundane, become sacramental agents of Communion. Margaret of Ypres, for example, experiences union with God via ravishment solely through her power of contemplation. Gazing upon a basin filled with grass, she is reminded of the eternally green grass of paradise. ${ }^{72}$ Contrasting with cinematic representation, however, in which film is an illusionary copy of reality, the

68 Translation from Lindberg, Theories, p. 99. 'Et cum gratiae infusio maxime manifestatur per lucis multiplicationem, expedit per omnem modum ut per mulitplicationes lucis corporales manifestentur nobis proprietates gratiae in bonis, et repulsa ejus in malis.' Bridges (ed.), I, 4.4.36.216. On this, see also: Hahn, 'Visio Dei', p. 175.

69 Bridges (ed.), I, 4.4.36.216-17. Bacon's analogy is an extensive elaboration of Robert Grosseteste's proposition of the necessity of the divine light of truth to understand correctly what is seen. On this, see: Crombie, pp. 128-31; Lindberg, Theories, pp. 98-99; Neaman, pp. 31-33.

70 P. 139 .

71 Sobchack, Carnal Thoughts, p. 71 .

72 VMY, 44.126. 
divinity 'onscreen' - such as Margaret's heavenly verdure- is actually the uncorrupted originator of all that is fraudulently experienced as reality in the earthly world 'offscreen'. Similarly, Beatrice of Nazareth's disdain for gold, silver, sumptuous apparel, and anything 'seen with bodily sight' alone ('que corporali cernuntur intuitu') displays her ability to discern the reality of the world. ${ }^{73}$ Such mortal things, although 'offscreen' and seemingly real, are illusory and meaningless if they are interpreted without an eye on the screen of God's majesty. The holy women's visual praxis thus incorporates them into the community of righteous viewers described in II Corinthians 4.18: 'While we look not at the things which are seen, but at the things which are not seen. For the things which are seen, are temporal; but the things which are not seen, are eternal. ${ }^{74}$ Moreover, the notion of sight as a conduit for authentic knowledge is reinforced.

The ability of holy women to experience visual phenomena synesthetically is most emphatically portrayed in visions of the Eucharist, in which the women see, taste, and ingest the body and blood of Christ literally. ${ }^{75}$ In a form of double vision, they can see what is 'onscreen' (Christ as flesh and blood) and 'offscreen' (the Eucharistic wafer and wine) in one glance. Such experiences function as 'hermeneutic visions' for the text's audience. ${ }^{7}$ ' $[\mathrm{H}]$ ermeneutic visions' operate on two levels simultaneously: the prescribed meaning to be derived from a scene is relayed in the same instance that this meaning's self-evidence and significance is emphasized.After swallowing Communion wine and meditating on Christ's suffering flesh, Beatrice feels Christ's blood pour into her own soul: 'it seemed to her that all the blood which flowed from his wounds was poured into her soul, and that all the drops of that precious liquid were so sprinkled on it that it was wholly washed by these drops and most perfectly cleansed from all the dust of

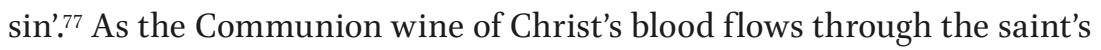
veins, Christ's blood is shown to infuse her very soul: the reality of transubstantiation is made visible. Sacramental wine does not just represent, but is literally Christ's blood.

75 For extensive examples and analyses of such instances of ingestion of the Eucharist in medieval female saint's lives, see Bynum, Fragmentation, pp. 119-50.

76 Campbell and Mills, 'Introduction', p. 3; Campbell, 'Sacrificial Spectacle', p. 104.

$77 V B N, 3.12 .238 .279$. 'visum est ei quod omnis sanguis qui ex eius vvnleribus emanauit, ipsius in anima funderetur:, omnesque gutte tam preciosi liquoris $<$ sic $>$ spargerentur in illa, quod ab hijs abluta penitus ab omni peccatorum puluere perfectissime mundaretur'. Ibid., 3.12.238.278. 
During mystical Communion, Margaret of Ypres not only sees Christ but is also able to chew and taste a sacramental wafer in her mouth. ${ }^{78}$ The text focuses on a particular bodily element: Margaret's teeth ('dentibus masticavit'). ${ }^{79}$ The holy woman sees Christ in physical form, without wound or division. Yet, she is able to chew and taste his flesh for a full fifteen days after the event. This vision shows Christ as whole (man) and part (in the form of the wafer), a visual elaboration of the tenet of the Trinity and the truth of transubstantiation. In response to an enquiring Cistercian monk, Yvette of Huy explains her experience during mass as follows:

'I am preoccupied with the joy and delight of Christ's presence so that nothing escapes or empties from my mouth. How else could it be, here where Christ is in person, the truth and power of the passion present in Christ's person, although not visible but latent under the shape of bread and wine, to strengthen the faith. And that suffering is still offered for salvation from the present faith to God the Father. The priest makes the sacrifice on the altar as on the cross, wondrous and ineffable [...] ${ }^{30}$

Sensuous visions of Christ's physicality in the Eucharist make such teaching obvious to the reader. In Brigitte Peucker's words, 'the material aspects of embodied spectatorship carry over to or are projected upon the image most fully, lending the image itself the semblance of materiality'. ${ }^{81}$ The reality of the saint's body lends the image of Christ a share of concrete materiality, which consequently endows it with a presence in the earthly world with which Christians can more easily connect: Christ is God in human form, fully present in the sacraments. There is a crucial difference between the modern and medieval scenario, however. The cinematic screen image is understood as fiction artificially accruing physicality. By contrast, from a medieval Catholic perspective the spiritual Christ-image ('film') reveals the

$78 V M Y, 24.118-19$. On this episode, see also briefly below: Chapter 4, p. 226. See also sweetness tasted by Beatrice of Nazareth, Ida of Louvain, and Marie of Oignies upon reception of the Eucharist: VBN, 3.5.206-07.239-41; VILov, 3.1.3.183; VMO, 1.2.23-24.642.

$79 V M Y, 24.118$.

80 VIHEng, 36.99.127-28. 'Ita congratulatione \& delectatione Christi dilecti mei praesentis sum occupata, vt aliquid ore dicere mihi nec vacet nec libeat. Quid ac haec illi, qui ibi vbi Christus personaliter, etsi non patens veritas \& virtus passionis adest in personâ Christi praesentis, sed latens sub specie panis ac vini ad fidem corroborandam, passus tamen pro salute suâ à praesentibus fide Patri Deo praesentatur, factus in altari sicut in cruce Sacerdos \& sacrificium mirabiliter \& ineffabiliter'. VIH, 36.99.882.

81 P. 159. See also Voss' concept of 'surrogate corporeality' (the spectator's body acting as surrogate for the film/screen): pp. 144-46, 149 . 
real and proper understanding of all life on earth ('offscreen'). The medieval saint's mortal body - subject to death, enmeshed in sin - is lent potent spiritual ('filmic') presence by the vision. Nevertheless, a secular critique of medieval Catholicism allows for the interpretation of the necessity of the saint's body to materialize the fiction of Christ's existence.

\section{Feeling What You See: Sensual Catechresis}

The holy woman's body mediates Christ's physicality in the world. Such heightened materiality, derived from visions, also impacts the holy woman herself. Divine visions often produce intense, and intensely personal, sensory effects in the visionary's own body. Juliana of Mont-Cornillon, for example, is so devout that she is unable to stay inside on the Feast of Ascension. ${ }^{82}$ She is compelled to go outside, her gaze drawn to the sky, which functions as the screen upon which Christ appears. Looking at the heavens, she sees Christ in 'human form' ('in humanitatis nostrae forma') ascending to the throne of his Father, as laid down in Acts 1.9. ${ }^{8_{3}}$ Watching a film offers a 'partially fulfilled sensory experience. ${ }^{84}$ The spectator's 'sensual desire' to touch onscreen objects thus reverses direction, returning to the moviegoer's 'felt lived body' in order to satisfy itself in a form of what Sobchack terms 'sensual catechresis'. ${ }^{85}$ The visual experience onscreen is transliterated into a tactile perception in the spectator's offscreen body. Juliana similarly experiences 'sensual catechresis' as, unable to experience fully the glory of God corporeally in the vision, tactile perception rebounds from her gaze on Christ's disappearing form into her own body. ${ }^{86}$ Her body, as with the spectator's 'lived body' in the cinematic experience, 'fills in the gap in its sensual grasp of the figural world onscreen by turning back on itself reciprocally [...] "flesh[ing] it out" into literal physicalised sense'. ${ }^{87}$ This sense is 'both literal and figural', corporeal and affective. ${ }^{88}$ Not only does she experience 'marvellous delight' ('mirabiliter delectari'), but she is overloaded with sensory experience to the point that her body almost bursts: 'she was so filled and overflowing with grace that her narrow body

\footnotetext{
82 VJC, 1.4.19.450-51.

83 VJCEng, 1.4.19.205; VJC, 1.4.19.451.

84 Sobchack, Carnal Thoughts, p. 76.

85 Ibid., p. 76 , p. 78 .

86 Ibid., p. 78 .

87 Ibid., p. 82 .

88 Ibid., p. 78 .
} 
could not contain its fullness, and her hostess was afraid that Juliana's body would burst and split down the middle. ${ }^{89}$ Bodily rupture is avoided by the expulsion of a cry - from Juliana's chest, not her mouth ('quam sine oris apertione, sed solo pectore proferebat') - which acts as an escape valve for the overloaded senses of her body.

Juliana's cry is characterized as a means to 'let some of the painful inner heat escape' ('[p]ro captanda vero aliquantula evaporatione ardoris, quem intra se patiebatur'). This is a bodily cry, one borne out of corporeal sentience rather than coherent intellectual experience. Although expressed in language, the cry is not satisfactorily communicative, at least from the perspective of Juliana's hagiographer. The saint proclaims "My Lord has departed!"', which is immediately followed by the hagiographer's gloss: 'Is it not as if she had said, "God has gone up with a shout of joy"? ?90 The cry follows its own logic, and does not function effectively as language. It is not expelled from the vocal canal, but instead from the core of Juliana's body. Returning to herself fully after witnessing the Ascension vision, she feels besieged by 'a heavy sadness' ('per quamdam moestitiae gravitatem'). The sadness, however, is due to her feeling of isolation. It is 'as if she had been left a lonely orphan' ('ac si sola fuisset \& orphana derelicta'). After her vision, which propelled her more fully into her own body and entailed an overflowing of her body with God's grace, she is left with an emptiness which underscores the overwhelming physical plenitude of the tactile visual act.

Beatrice of Nazarath focuses her gaze so obsessively on the sky that those around her mock her and think her insane. ${ }^{91}$ Her insistent look is provoked by her yearning 'to be dissolved and to be with Christ' ('dissolui cupiens et esse cum christo'), which is formulated in terms of mournful desire for reunion ('desiderium'). ${ }^{92}$ This parallels the 'sensual desire' in play in Sobchack's description of 'sensual catechresis', the tactile perception which ricochets into the spectator's body after its initial trajectory toward the screen, which results in an incomplete sensory experience. ${ }^{93}$ Beatrice is so absorbed in watching the film of Christ's majesty that she barely notices the worldly

89 VJCEng, 1.4.19.205-06. 'ad quamdam sibi dilectam personam visitandi gratia divertisset, sic repleta \& referta gratia fuit; ut plenitudinem ejus angusto corpore capere non valente, illa ad quam Juliana venerat plurimum timeret, ne disrupto corporis vasculo, sua visitatrix per medium scinderetur'. VJC, 1.4.19.451.

90 VJCEng, 1.4.19.206. 'At illa exclamavit \& dixit: Recessit Dominus meus. Nonne tibi videtur dixisse? Ascendit Deus in jubilatione.' VJC, 1.4.19.451.

$91 \quad V B N, 2.16 .157 .184-86$.

92 Ibid., 2.16.156-57.184-85.

93 Carnal Thoughts, p. 78 . 
happenings around her. Yet her fixation on Christ, and achieving union with him, results in extreme corporeal effects in her offscreen body: 'So much did her affection sigh for eternal things, so wounded and languishing with love was it that its vehement desire caused frequent and copious streams of blood to flow from her mouth and nose. ${ }^{94}$ Unable to dissolve into Christ literally, her contemplative visions of Christ allow an analogous tactile experience. She is able to feel her body in the process of breaking down and changing form.

Beatrice's concentration on the divine cinema screen, and its effects, are figured as evidence of extreme piety by her biographer. ${ }^{95}$ The text's audience, incapable of experiencing such heavenly joys, is characterized as 'inert, stolid' ('inertes et stolidi'), comprised of 'slack tepid people' ('tepidi et remissi'). Whilst such imperfect Christians focus on 'the filth of sin and earthly pleasures' ('peccatorum sordibus et terrenis voluptatibus inuoluti') - immoral sources of tactile pleasure found in the world outside of the cinema theatre, offscreen - Beatrice's extreme sensations are shown to be of the utmost purity and authenticity. Once more, the 'figural world onscreen' of the divine, literalized via corporeal sensation in the spectator's body, is shown in medieval hagiography to be a depiction of reality and not illusion. ${ }^{96}$ The body of film appears as that which 'is materialised in the contact between the film's perception and that of the spectator, namely in the fact of feeling the feeling of the film itself. ${ }^{\prime}$ Christ as God-made-flesh provides the 'skin of the [divine] film', the corporeal embodiment of abstract divinity brought forth by the perceptual interplay between Beatrice, her body, and God..$^{8}$ Christ, as the divine film's literal body, is modelled 'on human styles of bodily comportment, and the viewer's body in turn mirrors the muscular behaviour of the film's body' ${ }^{99}$

$94 V B N, 2.16 .159 .189$. ' $<$ sic $>$ ad eterna suspirans, vvlnerata simul et amore languens, affectio., vt ex eius ore, vel e naribus, copiosi sanguinis riuos frequenter, desiderij < nimij > feruore, eduxerit'. Ibid., 2.16.159.188. See similar remarks in ibid., 2.16.157.186. Ida of Louvain's arteries also burst, with blood flowing out of her mouth and nose during ecstatic union with God: VILov, 2.3.14.174. $95 V B N, 2.16 .158 .186-87$.

96 Sobchack, Carnal Thoughts, p. 82.

97 My translation; emphases in original. '[...] surgit dans le contact entre la perception du film et celle du spectateur, à savoir dans le fait de sentir le sentir du film.' Dalmasso, 'Toucher', p. 83 . On the filmic body, see also: Barker, pp. 4-13; Dalmasso, 'Toucher', pp. 81-87; 'Voir', pp. 118-21; Sobchack, Address, pp. 164-259.

98 Marks, Skin, title, and passim. According to Marks, the cinematic epidermis is the surface of the filmic image and its concomitant tactile properties, a surface which can be 'touched' in various ways by spectators: ibid., pp. xi-xii, pp. 19-23. Other film scholars use this term in a broadly similar manner, see for example: Hiltunen; Laine; Rutherford.

99 Barker, p. 77. 


\section{The Collective Spectatorial Body}

Sobchack maintains that in viewing cinema, the spectator's body is the 'third term' which 'grounds and mediates experience and language, subjective vision and objective image.' ${ }^{100}$ The spectator is forever torn between the intangible illusion of reality portrayed onscreen, which nevertheless possesses the ability to move us emotionally and physically, and the actual reality of lived experience offscreen, the recognition that the spectator is sitting in a cinema, watching unreal events unfold. For onlookers, the visionary woman acts as a form of collective spectatorial body. She mediates between the reality 'onscreen' (God's grace and divinity) and the concrete, earthly reality 'offscreen' (the lived experience of earth-bound Christians who have not been blessed enough to 'see the film' of God's supreme grace). With saintly vision and as a solitary cinema-goer, she alone can see what is 'onscreen' and relays this as fully as possible to those locked into their 'offscreen' corporeal reality. During ecstasy one day, Juliana of Mont-Cornillon communicates with the apostles Peter and Paul. ${ }^{101}$ She is fully focused on the content of her vision, the 'film' of divinity now showing His apostles 'onscreen', and her 'offscreen' body is in a coma-like stasis ('membrorum suorum pernitus non movendo'). A spiritual colleague, the recluse Eve of Saint-Martin, witnesses the scene and rushes to the saint's aid, thinking her ill. However, as the helpful recluse nears Juliana, she can hear the saint speaking with the two apostles ('audivit ipsam cum beatissimis Petro \& Paulo Apostolis colloquentem').

Eve, less spiritually perfect, cannot see or interact with the apostles directly: she is not in the cinema theatre alongside Juliana. Nor can the recluse understand the content of Juliana and the apostles' conversation. When Juliana opens her eyes and returns from rapture, excitedly announcing '[l]et's go!"' ('[e]amus') to her companion, the recluse has no idea to what or where the saint refers. She replies with a question: "Where shall we go, my lady?"' ('Et quo [...] Domina mea, ibimus?'). The swift response of the saint - "'To Rome, to the apostles!'” ('Romam ad Apostolos') - suggests that the destination of the trip should be obvious, presumably relayed by Peter and Paul during her rapture. In this scene, the reader is aligned more closely with Eve than the saint: the text does not divulge the content of Juliana and the apostles' interaction. The reader, too, is definitively 'offscreen' and must rely on the saint to proffer the knowledge she gains from the divine film. 
Ultimately, the reader is at an even further remove. The text is the screen upon which we 'watch' the saint, and, at times, is the screen upon which we 'watch' people watching the saint.

Juliana's most important vision is of a full moon marked by a black spot. ${ }^{102}$ Christ reveals to her the significance of the image: 'the moon was the present Church, while the breach in the moon symbolise[s] the absence of a feast'. ${ }^{103}$ She alone receives such teaching from the Lord as to the necessity of a new Church rite, the Corpus Christi Feast. Juliana is the only individual with a valid ticket to see the Lord's film. Her divine knowledge is relayed to the most illustrious and learned theologians in the region, including Jacques of Troyes (archdeacon of Liège and future pontiff Urban IV; d. 1264), Hugh of SaintCher (d. 1263), bishop Guiard of Cambrai (d. 1248), the chancellor of Paris, and several Dominican friars. ${ }^{104}$ Juliana's biographer goes to great lengths to emphasize the piety and theological erudition of each of these clerics. Hugh and John, for example, are described as two bright stars shining in the firmament of the Church due to their perfect lives and immense sagacity ('duo caeli luminaria magna, vita \& scientia, in Ecclesia refulgebant'). The response of such learned men to Juliana's vision is overwhelmingly positive, all unequivocally agreeing to the institution of the Corpus Christi Feast. Thus, Juliana's spiritual insight from 'watching the divine film' puts her on some kind of footing with churchmen of great renown and holding high clerical offices in the 'offscreen' world, as long as she is submissive and acts only according to God's will. Nevertheless, Juliana's message stands up to close theological inspection. She is an efficient divine mouthpiece, and does not mangle His words. It is only after careful examination and analysis of the situation that these men give their approval. Having garnered the approbation of key clerical figures, the Feast of Corpus Christi debuted at the basilica of Saint-Martin in Liège in 1246. In August of 1264, the Feast was added to the calendar of the Church by Urban IV in his bull Transiturus de hoc mundo. ${ }^{105}$

On 8 September 1264, Urban IV wrote to Eve of Saint-Martin, communicating his decision to institute the Feast officially and recognizing both Eve and Juliana's involvement in its inception. This letter could be interpreted

102 VJC, 2.2.6.459.

103 VJCEng, 2.2.6.234. 'in luna, praesente Ecclesiam; in lunae autē fractione, defectum unius solennitatis in Ecclesia figurari'. VJC, 2.2.6.459. For details of the Corpus Christi Feast, its originating vision, and its promotion see: ibid., 2.2-3.6-15.459-64. See also: Rubin, pp. 164-287. On the importance of the Eucharist for female religious, and female Eucharistic devotion, see: Bynum, Fragmentation, pp. 119-50; Holy Feast.

104 VJC, 2.2.7.459-6o.

105 Denzinger (ed.), pp. 279-82, DS 846-47. 
as official clerical recognition of a 'new feminine authority' ('nouvelle autorité féminine'), based on the privileged spiritual knowledge available to Juliana as a spectator of the 'divine film' ${ }^{106}$ The role of holy women as mediators in religious worship and in shaping ecclesiastical praxes is also tacitly approved. Less religious mortals watch the spectacle of holy women watching the 'divine film', and thereby access divinity themselves (visually and haptically), ultimately coming to comprehension of necessary Catholic rites and rituals. Nevertheless, this new brand of 'feminine authority' only achieved its apogee in the official promulgation of the Corpus Christi Feast six years after Juliana's death. She herself was never to enjoy it. Moreover, the controversy surrounding the Feast in the diocese of Liège was not resolved until 1287 when it was officially recognized in the synodal statutes of bishop John of Cambrai. The insistence of Juliana's biographer on the speedy acceptance of the Feast in Liège, with resistance being portrayed as occurring only elsewhere and as a result of diabolical interference, is an attempt to minimize the immense difficulty of instituting the Feast as an obligatory form of Catholic worship. ${ }^{107}$ Similarly, it serves to highlight the superiority of Juliana's approach, combining activity and passivity.

Rather than an active agent in the worldly machinations surrounding the Feast's foundation, Juliana is portrayed by her biographer as a conduit used by God to relay His will. Her function as a screen which reveals God's plan also involves an element of concealment - obscuring her precise role in the scenario. She may well function as the receptive body of the film (the screen upon which it is projected), but its contents are relayed by the bodies of others. For example, John of Lausanne acts as an intermediary between Juliana and the clerics. ${ }^{108}$ He relays the content of Juliana's vision whilst concealing her name ('tacito tamen nomine suo'), and thus her involvement in the Feast. She is conspicuously absent from passages detailing the spread of the Feast throughout the powerful networks of clerics. ${ }^{109}$ Her sole manner of influencing its institution is by becoming once more absorbed in the 'onscreen' divine action: she makes pilgrimage to Cologne and prays to saints for their intercession in the matter. ${ }^{10}$

106 My translation; Bartoli, p. 79. For the letter, see: VJC, 2.9.55-56.477; VJCEng, 2.9.55.298-300.

107 VJC, 2.3.10.46o-61.

108 Ibid., 2.2.7.459-6o.

109 Ibid., 2.2-3.9-10.460-62; 2.3.13-15.462-64.

110 Ibid., 2.3.11.461. 
In the final moments of her life, Yvette of Huy's gaze is clearly fixed on the heavens, watching the divine film into which she will finally be absorbed upon her expiration:

With smiling face, open hands, eyes elevated to heaven, as though applauding those who were coming, she went on her way, lit by the lamp of virtue and the oil of good conscience. So her soul was lifted from her body, like another Moses raised from the basket among the bulrushes by the king's daughter. The Virgin Mary presented the faithful one, laid before the King, her Son who raised her up a daughter and inheritor of the kingdom. ${ }^{111}$

By watching Yvette watching God, her spiritual companions access His grace also: 'And those who were about her in the house were rapt in spirit as in ecstasy and were full of wonder at the marvellous sweetness of the ineffable grace and elevation of mind so that none of them could doubt the presence of our God and Lord, Jesus Christ."112 Yvette's failing body, as with the spectatorial body, 'prereflectively grounds the more particular and reflective discriminations of a "higher order" semiology' for her devotees. ${ }^{113}$ They are transported into ecstasy immediately ('prereflectively') upon the elevation of Yvette's soul, and cannot but wonder at the superior powers of reflection - in the double sense of contemplation and the ability to promulgate God's authenticity - which the saint possesses. Her followers cannot themselves 'watch the film' of God's majesty, but can watch Yvette 'watching the film' firsthand, directly experiencing it themselves in her final moments. The onlookers, rapt by witnessing Yvette's direct visual experience of the divine, are positioned on a lower rung in the hierarchy of viewing experience. Yvette, as the collective spectatorial body, allows for God's majestic presence to be made clear to her community. The holy woman's function is made explicit in her vita, as Hugh of Floreffe enjoins the reader to meditate on Yvette's pious works:

111 VIHEng, 49.119.138. 'hilari vultu, propansis manibus, oculisque eleuatis in caelum, quasi venienti applaudens exire nitebatur obuiàm cum lampade virtutum \& bonae conscientiae oleo: cùm ecce assumptam de corpore animam, velut alterum Moysem è fiscellâ sublatum scirpeâ, filia Regis Virgo Maria, Regi filio velut depositum fidele repraesentat, sublimandam in filiam regni \& heredem'. VIH, 49.119.885.

112 VIHEng, 49.119.138. 'Et qui in domo circa ipsam erant, ac si in extasi rapti essent spirituum, repleti sunt mirâ quadam \& indicibili gratiâ mirificae suauitatis \& eleuationis mentium, adeò vt ipsius Dei ac Domini nostri Iesu Christi praesentiam nemo esset qui ambigeret.' VIH, 49.119.885 113 Sobchack, Carnal Thoughts, p. 61. 
Whose glory do you suppose, oh my reader, this woman displayed who now reigns with God in heaven and was so close to him on earth, that he often confided the secret counsels of heaven to her, using her, so to speak as the mediatrix between heaven and earth, visible and invisible, God and man for the correction of many. ${ }^{114}$

The Sobchackian 'sensual catechresis' that a saint experiences in her own body during rapture - i.e. the overwhelming physical sensation reverberating backwards from the screen - also flows into the bodies of her followers as miracles. ${ }^{115}$ On one occasion, for example, Ida of Louvain heals a disastrously diseased individual with a single look ('ad primum sanctae mulieris aspectum'). ${ }^{116}$ The anonymous male patient has already received the last rites in deference to his imminent passing when Ida arrives at his bedside. He musters his strength and shows the holy woman his horrendous affliction, 'a widespread swelling known as a carbuncle, a disease-laden tumour of a kind that would be wondrous were it not so woeful'. ${ }^{17}$ The graphic description of the nastiness of the affliction renders the ensuing description particularly surprising. Immediately after Ida glances at the tumour on the patient's body, the sufferer's woe is transformed into wonder as he is fully healed. ${ }^{118}$ Unable himself to see the film of God's divinity onscreen, the patient is sensually pushed back into his own body and attains vision through the projection of God's gaze through Ida's holy look. The forceful penetration of Ida's look literally expels the pus and its attendant swelling. The patient's experience of 'sensual catechresis' is 'both literal and figural'. ${ }^{19}$ He is healed in body but also, implicitly, in soul, as he joins 'the assembled multitude in thanking God for this gift of health'. ${ }^{120}$ He is now able to rejoin the community of devout Christians, joining the pious throng who recognize God's glory as the originator of the miracle.

114 Emphases mine. VIHEng, 41.107.131. 'Cviusue putas existat gloriae mulier haec in caelestibus iam cum Deo regnans, ô qui me legeris, quae in terris adhuc tanti à Deo habita est, vt internis caelestium secretorum consiliis tam frequenter admissa, mediatrix quodammodò haberatur ad correctionem multorum, inter caelestia \& terrestria, visibilia \& inuisibilia, inter Deum \& homines.' VIH, 41.107 .883 .

115 Sobchack, Carnal Thoughts, p. 78.

116 VILov, 2.1.3.171.

117 VILovEng, 2.2.3c.39-40. 'erat quippe pestiferae turgiditatis illius, scilicet quam anthracem nominant, nõtam mirabili quam miserabili nimis inflatione pervasus'. VILov, 2.1.3.171.

118 VILov, 2.1.3.171.

119 Sobchack, Carnal Thoughts, p. 82.

120 VILovEng, 2.2.3c.40. 'ac super adeptae beneficio sospitatis omnipotentis Dei clementiam, una cum omni congregata populi multitudine, benedixit'. VILov, 2.1.3.171. 
Ida's appearance at the man's bedside is shown to be an act of God. He literally guides her way towards the patient's house: 'Off she went, abandoning herself to the Spirit's lead [...]. She made her way - whither, not she but the Holy Spirit, listed and led [John 3.8] - until finally she arrived at a house'. ${ }^{121}$ In essence, God has harnessed Ida's body to do His bidding, and share His gaze. The Virgin Mary serves as prototype for this manoeuvre, as God takes over her virginal body and implants His son in her womb. The holy appropriation is made explicit in Luke 1.35 as an angel tells Mary: 'The Holy Ghost shall come upon thee, and the power of the most High shall overshadow thee.'122 Ida and the other Liégeoises have a powerful precedent for the way in which God 'borrows' female bodies to make his divinity physical in the world.

\section{Coresthesia: Reading, Seeing, and Touching the Corpus}

The tactility of the cinematic look is presented by theorists of embodied film spectatorship as 'a special example of [the] enfolding of self and world, an intensified instance of the way our perceptions open us onto the world'. ${ }^{123}$ The dissolution of boundaries between viewing subject and viewed object, and the imbrication of the body in the act of visual perception is situated squarely within the boundaries of the movie theatre. The medieval sensorium, however, posits haptic interpenetration of viewed and viewer as a necessity for the occurrence of vision. Medieval saints see and are seen by God. This is a mutually constitutive experience, emphasizing both union in divinity and separation in an individual body at the same instance. However, this experience operates differently for God and the saint: it is epistemological for the former, and ontological for the latter. The saint experiences her reality through God, but cannot shore up His being. She disseminates knowledge of Him to Christians in the mortal world. Nevertheless, the impression of species in the medieval viewer's eye enacts a literal incorporation of the viewed item, allowing for intensely physical encounters with Christ, God-in-human-flesh.

In the medieval era, seeing and reading were ordered according to the same theories of perception, designated as different 'modes of visual perception'. ${ }^{124}$ As Starkey summarizes, in the Middle Ages,

\footnotetext{
121 VILovEng, 2.2.3a-b.39. 'Quem sequens Virgo venerabilis, ejusque ducatui se committens [...]. Pergens igitur, non quo vellet ipsa, sed quo Spiritus sancti duceretur instantia, tandem ad domum cujusdam languidi'. VILov, 2.1.3.171.

122 Douay-Rheims Bible.

123 Marks, Skin, p. 149.

124 Starkey, p. 3 .
} 
The processes for perceiving words and images were deemed to be similar. Both involved reading (aloud), thought, and visualization. Images and texts thus functioned similarly and were perceived as complementary means by which one might achieve the same results. The relationship between text and image or word and image is now regarded by many scholars as discursive, indeed symbiotic. ${ }^{125}$

Medieval hagiographic texts, as physical object and narrative content, can be understood in terms utilized throughout this chapter borrowed from embodied cinematic spectatorship. The narratives, like the medieval saint, are screens upon which God's divinity is displayed: they contain witness accounts of spiritual miracles and instances of divine sight. Such proofs of divinity are laid down on vellum, an overlay of graphic images on a blank surface akin to the projection of God's divine film onto the body of the saint. The medieval hagiographic text functions as a Sobchackian collective spectatorial body, 'mediat[ing] the meaning and even the possibility of [divine] sight'. ${ }^{126}$ Furthermore, it is the text which directs the reader's internal gaze here or there, privileges one image over another, and even denies sight by refusing to show what readers yearn to see. The text, as the film, structures the visual experience.

Reading a manuscript implicates tactile perception as much as seeing an object depends on the mechanisms of haptic apprehension. Moreover, manuscripts were not just objects of (haptic) visual perception, but were objects with which readers had a highly tactile experience. ${ }^{127}$ The canon page of a missal, for example, would repeatedly be kissed by its priestly owner, resulting in the deposition of 'secretions from his lips, nose, and forehead onto the page'. ${ }^{128}$ Readers would glue other devotional objects into a manuscript's binding, modifying the structure of the text to fit their own purposes. ${ }^{129}$ Eucharistic tokens, religious souvenirs commemorating the fact that a devotee had taken communion, were commonly sewn into personal manuscripts in the fifteenth century. ${ }^{130}$ Such modifications transformed the manuscript into a 'shrine, marking its owner's direct contact with the

125 P. 4. On this, see also: Camille, pp. 216-17; Campbell, Lives, pp. 129-31; Corbellini, pp. 2, 5; B. Newman, 'Clash', pp. 17-18. 126 Hahn, 'Visio Dei', p. 170. 127 On this, see in particular: Borland, 'Violence', pp. 75-78; 'Unruly Reading'; Rudy, 'Dirty Books'; 'Kissing Images'; Schleif, 'Communities'.

128 Rudy, 'Dirty Books', n.p.

129 On such customization, see in particular: Rudy, Pieces; Postcards.

130 Rudy, 'Wafer Souvenirs'. 
wafer'. ${ }^{131}$ In this way, the manuscript perpetually memorialized the Eucharistic experience, conserving the divine presence in its material support.

All elements of the manuscript were open to haptic engagement. For example, readers would repeatedly touch illustrations in texts, with such repeated rubbing leaving the images difficult to make out for the modern reader. Dirt and fingerprints overlay manuscript folia, signs of the reader's multimodal interaction with the text. Kathryn M. Rudy's 'forensic' research reveals the traces of past readers, objectively charting the caress of the reader's fingers as they traverse the text. ${ }^{132}$ Rudy employs a piece of scientific apparatus, a densitometer, to produce her results. The densitometer records a measurement of the darkness of a reflecting surface. The darker the manuscript support, the more dirt ingrained in the support - and thus, the greater the wear. Such usage patterns reveal that, often, manuscript owners 'treated their manuscripts as a proxy for the body of Christ, with which they were encouraged to cultivate a close physical relation'. ${ }^{133}$ In a passage from his Dialogus miraculorum, Caesarius of Heisterbach explicitly evokes the manuscript form as an authentic surrogate for Christ. Christ is the 'book of life' ('[l]iber vitae'), a manuscript-body upon which human salvation is inscribed:

Christ wrote this book because he suffered by his own will. The small and black letters were written by the bruising blows of the scourge on the parchment of his body; the red letters and capitals by the piercing of the nails; and the full stops and commas by the pricking of the thorns. Well had that parchment already been polished with a multitude of beatings, whitened by blows and spit, and erased with the red. ${ }^{134}$

A saint's body is a screen for God's divinity in a vita's diegesis. That textual body's material form, the manuscript, similarly serves as a connotatively

131 Ibid., para. 2.

132 Rudy, 'Dirty Books', n.p.

133 Rudy, 'Kissing Images', p. 1.

134 Translation from M.G. Newman, p. 182. 'Librum hunc Christus ipse scriptsit, quia propria voluntate passus est. In pelle siquidem corporis eius scriptae erant litterae minores et nigrae, per lividas flagellorum; literrae rubeae et capitales, per infixiones clavorum; puncta etiam et virgulae; per punctiones spinarum. Bene pellis eadem prius fuerat multiplici percussione pumicata, colaphis et sputis creata, arundine liniata.' Caesarius of Heisterbach, I, 8.35.108-o9; cited by M.G. Newman, pp. 201-02, n. 1. I discuss the resonance of red ink as blood and the scoring marks of columns on parchment as 'wounding' in a manuscript of Alice of Schaerbeek's vita in 'Suppurating Wounds', p. 401. On the 'book of life' as a term for a specific hagiographical genre, and in visions in the corpus, see: pp. 32-33 above and 206 below, respectively. 
Figure 7 Manuscript illustration of Olibrius the prefect, with abrasions

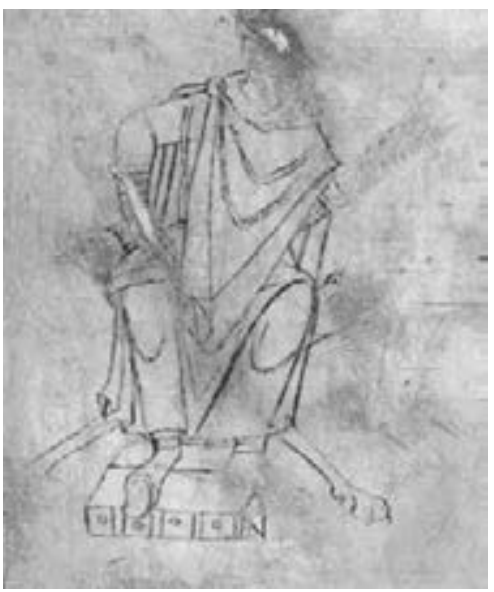

Reproduced with permission, from Munich, Bayerische Staatsbibliothek, MS CIm. 1133, fol. 69v , urn:nbn:de:bvb:12-bsb00065187-3
Figure 8 Manuscript illustration of St. Margaret, unmarked, between two guards, with head and feet erased

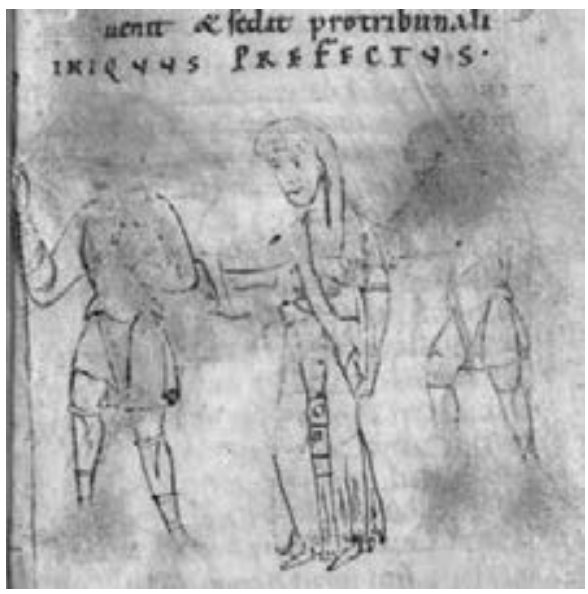

Reproduced with permission, from Munich,

Bayerische Staatsbibliothek, MS CIm. 1133, fol. 70', urn:nbn:de:bvb:12-bsb00065187-3

Christological screen. God is projected upon this Christ-screen, rendering his divinity haptically and visually perceptible. The manuscript, as with Christ himself, acts as a vehicle for the spiritual text's message, transmitting it to all those who read/see it.

Whilst righteous devotional illustrations or texts may be lovingly caressed by the medieval reader as Christ-like matter, manuscript defacement reveals the reader's deliberate rejection of sinful or immoral textual elements. For example, Jennifer Borland's examination of a twelfth-century copy of the Latin vita of the early Christian martyr St. Margaret (d. 304) reveals the systematic erasure of illustrations of evil-doers. ${ }^{135}$ In one illustration, the figure of pagan prefect Olibrius, the chief villain of the piece, shows clear signs of vigorous abrasions (Fig. 7). In the image on the facing folio, two of Margaret's guards bear the marks of readers' efforts at elision, whilst the saint herself remains undefiled (Fig. 8). The deliberate choice of dismembering Olibrius and the guards, rubbing out their heads, is particularly resonant given Margaret's ultimate fate: beheading. Such interactions with 
the manuscript render Margaret's incorruptibility due to her piety, the vita's central motif, physical in a manner that the text cannot achieve directly: tangibly and visibly. After feats signifying miraculous bodily cohesion, including being swallowed whole by a dragon and emerging without incident, Margaret ultimately dies due to her beheading. Her pagan tormentors remain physically intact, though spiritually corrupted. The defacement of other characters - beheadings achieved by readers' fingers - renders Margaret even more prominent to the visual narrative, her sanctity even more emphatic. ${ }^{136}$ What's more, the exclusion of Margaret from deletion signals the reader's (or readers') personal identification with the saint. The manuscript parchment functions 'as a double of human readers' skin'. ${ }^{37}$ Deliberate alterations to the images equates to the reader's re-enactment of Margaret's rejection of paganism and her heroism in conflicts with her torturers.

As Sarah Kay argues, the physical state of the parchment upon which a text is inscribed may, consciously or not, serve as 'a graphic realization of the text's content, an uncanny precipitate of its ideas in concrete form'. ${ }^{138}$ For example, the 'sublime appearance' of the highest quality, silken parchment represents the incorruptiblity or immortality of characters within the diegesis. By contrast, a narrative replete with images of torture and physical degradation could be intensified by the grisly facts of its material form: parchment, resulting from the flaying of animals, processes which would kill a human. ${ }^{139} \mathrm{~A}$ reader's attention is drawn ineluctably to this violent production process by the occurrence of defects in the parchment, including holes, slits, discolouration, and stretch-marks. ${ }^{140}$ Such is the case with damage evident in a fifteenth-century copy of Alice of Schaerbeek's vita. ${ }^{141}$ A small hole marks the text's last folio. Though long since repaired, its jagged extent is plain, almost as prominent to the reader/viewer as the restorative stitches themselves. Seen from the folio's recto side, the hole compromises the parchment upon which the most graphic description of Alice's physical breakdown is inscribed:

136 Borland, 'Unruly Reading', p. 111.

137 Kay, 'Legible', p. 16.

138 'Original Skin', p. 36.

139 On flayed skin (animal and human) and medieval reading, see in particular: Kay, 'Flayed Skin'; 'Original Skin'; Mills, 'Bare Life'.

140 Kay, 'Original Skin', pp. 35-36.

141 Vita Aleydis de Scarembeka. The manuscript, produced by Johannes Gielemans c. 1470-1486 was once owned by Augustinian canons in Rooklooster, Brussels. I discuss this manuscript and the valency of its repaired folio in: Spencer-Hall, 'Suppurating Wounds', pp. 400-01. 
Her hands, so needed for even her restricted uses, were long since all shrunken from the illness. Their skin was fissured with multiple wounds, like the bark of a tree. [...] The skin of her chest, head and arms, likewise resembled tree bark, scored unevenly and cracked from the excessive dryness. Her legs closely resembled a calf that has been skinned. They were also swollen, as were her feet. From her body there oozed loose flesh and abundant pus. ${ }^{142}$

The hole in the parchment reflects the way in which Alice's own skin is splitting, as leprosy marks the surface of her body with myriad wounds. The holy woman's excessively dry skin does not even resemble human skin any longer. Alice's legs now appear to have been flayed of skin, an image which cannot but bring to mind the manufacturing process of parchment, a process to which the very piece of parchment which conveys this grim information has been subject.

The manuscript corresponds to Alice's material form in terms of the degradation both have suffered through flaying. In addition, the manuscript support does what Alice's own skin no longer can: provides an envelope in which her essential qualities are contained for perpetuity. The manuscript's damage has been 'healed' - the hole that wounds the parchment has been carefully sutured together. On the verso, the stitching coincides with the description of Alice's miraculous skin-shedding as she divests of her mortal body and accedes to her spiritual form in heaven: 'Thus did she doff the robe of mortality and wretchedness, and don that of immortality and glory, a happy robe, full of gladness." ${ }^{143}$ The manuscript is neither breaking down fully nor perfectly whole, like Alice's body itself.

Returning to the traces left by reader interaction with manuscripts: Borland explicitly links her analysis of the image modifications in the manuscript of Margaret's vita with Bacon's synthesis of extromission and intromission. ${ }^{144}$ Indeed, the erasures from this manuscript are a vivid example of the intermingling of sight, reading, and touch in the medieval

142 VASEng, 3.31.31.37-38. 'Manus suae ad modicum usum errant sibi necessariae: nam ex nimia infirmitate per longa tempora fuerant contractae; quarum cutis, ad modum cortices alicujus arboris, variis distincta vulneribus, similitudinem ejus gerere videbatur. [...] Cutis quoque pectoris, capitis, \& brachiorum, similis erat cortici arboris, varias rimas ex nimia ariditate continentis, Crura ejus, vitulo excoriato errant simillima, \& ipsa una cum pedibus fuerunt inflate. De corpore ipsius carnes \& sanies abundanter effluebant.' VAS, 3.31.482.

143 VASEng, 3·32.32.29. 'Exuit enim tunicam mortalitatis \& miseriae, \& induit tunicam immortalitatis \& gloriae, plenam felicitatis \& laetititiae'. VAS, 3.32.482.

144 'Violence', p. 77; 'Unruly Reading', pp. 109-10. 
period. An individual engages in haptic relation with Margaret's body by reading the text, which leads to a direct physical interaction with Margaret's imaged body in its material form (manuscript). This outward-directed action towards Margaret's 'body' (image and manuscript) rebounds into the reader's own body, in the process of identification with the saint through deliberate tactile engagement with the manuscript. Borland describes her own 'visceral experience' of handling the manuscript, positioning her own physical response to it at the modern end of a spectrum of haptic interplay with the codex which began with its medieval readership. ${ }^{145}$ The defacements, she argues, offer an 'indexical marker' of 'previous handlers'. ${ }^{146}$ Catherine Brown chronicles a similar experience reading a twelfth-century manuscript of Augustine's Confessions ${ }^{147}$ As she reads, she perceives another 'reading with' her: a medieval commentator, leaving traces of his existence in the form of marginal notes (Fig. 9). ${ }^{148}$ Brown and the medieval commentator read together in a space outside of linear temporality, and become 'coeval', two beings with connected consciousness conjoined in a moment of disquieting simultaneity. ${ }^{149}$ In this encounter, the binary classifications of subject/object, self/other are precarious, insufficient for fully grasping the signification of the transchronological rendezvous.

The medieval reader is dead. Yet, they are also brought to life by Brown's reading, and come to inhabit her momentarily, as they inhabit the manuscript permanently in the form of their annotations. Brown summarizes the meeting: 'We look at each other, medieval and nonmedieval, human and text, each with demands and claims that change the other. ${ }^{150}$ This process is fundamentally dynamic, and enacts some form of transformation within both parties, medieval and modern. Thus, this manuscript-based interchange is analogous to the neomedievalist project as a whole: a trans-historical approach which opens up new interpretations for the medieval and modern alike. In an article calling for the reclamation of enjoyment as a key motivator of the medievalist project, Louise Fradenburg proclaims that 'we need to

145 'Unruly Reading', pp. 106, 109.

146 Ibid., p. 106.

147 'Middle', pp. 551-68, in particular pp. 551-53. She refers to Chicago, Newberry Library, MS $12 \mathrm{~V} .7$.

148 'Middle', p. 551. On the manuscript as a bridge between temporal periods of different readers, see also: 'Manuscript'.

149 Emphasis in original; C. Brown, 'Middle', p. 553. On this, see also: ibid., pp. 554-55; Schleif, 'Communities', pp. 74-75.

150 'Middle', p. 565. 
Figure 9 Section of manuscript folio, showing text of Augustine's Confessions (left) and medieval commentator's notes (right)

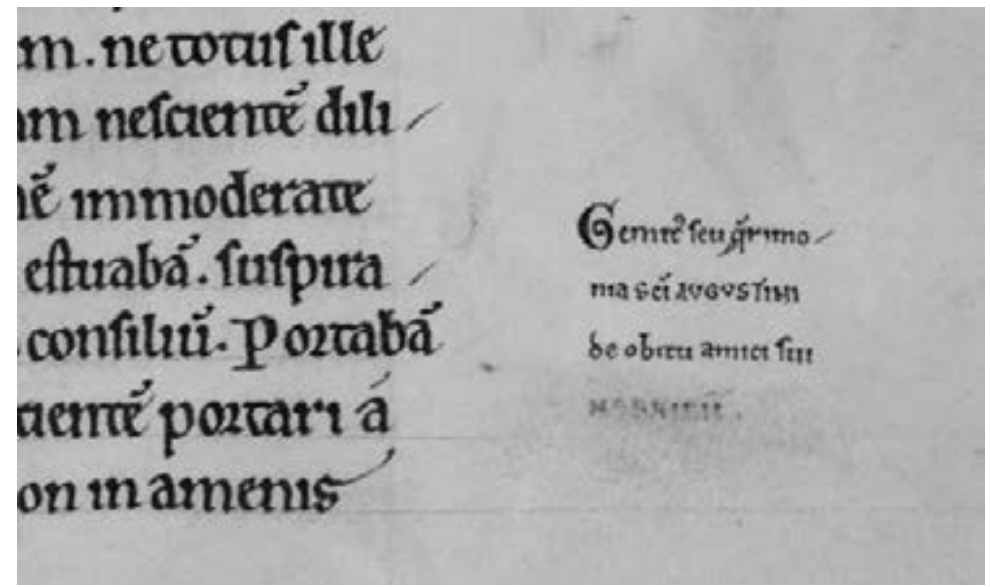

Photo courtesy of The Newberry Library, Chicago, Call \# MS 12 vol. 7, fol. 22

write histories of how the past is in us, our identities being as temporally unstable as they are in other ways'.51 Borland, Brown, et al. offer a joyful response.

In place of Sobchack's 'cinesthesia' (cinema, synaesthesia, coenesthesia), I suggest the term 'coresthesia' (corpus, synaesthesia, coenesthesia) to describe the specific effects of interaction with the medieval manuscript, or corpus. Interaction with a manuscript entails the imbrication of the reader's entire body and affect with the textual presence of a narrative (content), historical readers, and the text's material form. The processes of reading the words, seeing illustrations, touching the text's support, and being touched affectively by the text's content, are conjoined, non-hierarchical operations which shape the experience of a text.

Researchers have started to sequence the DNA of medieval manuscripts, extracting genetic material from vellum in order to date more precisely the writings etched on its surface. ${ }^{15^{2}}$ Such developments render the polyvalency of the word 'corpus' in the portmanteau 'coresthesia' even more potent. 'Corpus' denotes both the body of a man/animal and a body of literature. Now, a textual corpus can be treated as a corporeal artefact in its own

151 P. 214; emphasis in original.

152 See, for example: 'DNA Testing'; Drout, 'Crazy Sheep'; 'Sheep DNA (Again)'; 'Prototype’; Fiddyment at al; Gibbons; Teasdale et al. 
right. Manuscripts comprised of vellum folia quite literally have a skin, and this skin interfaces with our own as we touch a manuscript, even just to turn the page. Early iterations of the manuscript genetics project ran into a significant problem: the intermingling of the readers' and scribes' DNA with that of the book itself. As project leader Michael Drout explained on his personal blog in January 2009:

When you have about 1000 years worth of touching and rubbing along the edges of books, you end up with a lot of DNA cross-contamination, not just from human DNA that has rubbed off (which you can rule out by using different primers), but from the various leaves bound together in the manuscript (for example, if someone touches leaf $42^{\mathrm{r}}$ and then touches leaf $45^{\mathrm{v}}$, particles of DNA from one can be transferred to the other). ${ }^{153}$

The manuscript becomes a vector of trans-temporal touch. The integrally connective function of the manuscript pre-dates the advent of DNA technology, however. Corine Schleif, for example, studies a series of illustrations in the tenth-century Hornbach Sanctuary which visualize the haptic chain of engagement facilitated by the manuscript itself. ${ }^{154}$ In these images, five individuals are depicted passing a codex - the Sanctuary volume - to one another consecutively. The illustrations present the dedicatory context to the manuscript: who wrote it, for whom, and for what higher purpose. The book travels from the scribe Eburnant to Abbot Adalberg, the book's commissioner, then to Pirmin, the founder of the Hornbach monastery, and on to St. Peter, who finally hands the codex over to Christ. The manuscript is a product of these individuals, through literal manual work, economic support, or spiritual inspiration. At the same time, the manuscript enfolds and embodies these men, absorbing them into its very being as illustrated figures, demonstrating the intimate and reciprocal form of engagements between reader(s) and corpus more generally.

We become what we read as it becomes part of us. The manuscript lives on in us in our recollections, and we, quite literally, live on in the manuscript. A spectrum of haptic visual experience extends between the medieval and modern periods. The viewing praxes of the Middle

153 'Sheep DNA (Again)', n.p.; emphasis in original.

154 'Memorials', pp. 81-83. For the illuminations, see: Sacramentarium Sancti Petri Gamundiensis (known as Hornbach Sacramentary), Zentralbiblothek, Solothurn, Switzerland, Codex U1, fols. $7^{\mathrm{v}}-11^{\mathrm{r}}$. 
Ages are not petrified mechanisms of magical thinking, but overlap and conjoin with our own visual modes. Similarly, manuscript scholars are not definitively separated from the medieval individuals whose reading practices and cultures they study. Though a temporal divide exists, all readers meaningfully interact with each other via the body of the text and the body of the manuscript. 



\section{The Xtian Factor, or How to Manufacture a Medieval Saint}

\section{Marie of Oignies, the Celebrity Saint}

Legendary Classic Hollywood film producer Samuel Goldwyn declared: 'God makes the stars. It's up to the producers to find them.' Frankly, that's old news - at least to Jacques of Vitry. Jacques was a dedicated, even overly conscientious, student of theology in Paris when he first heard about Marie of Oignies. ${ }^{2}$ Lured by word of her localized religious fame, Jacques journeyed to the holy woman's home in Oignies in c. 1208. Meeting Marie was, in Ernest W. McDonnell's words, the 'big event' of Jacques' life. ${ }^{3}$ The cleric had found his religious star. Now, he could capitalize on Marie's regional acclaim and produce an A-list holy icon. In 1215, two years after Marie's death, Jacques authored a vita. The biography made a celebrity of its protagonist, and Marie's piety became well-known across Europe.

This chapter is a case-study of the spiritual celebrification of Marie of Oignies by her hagiographer, Jacques of Vitry. ${ }^{4}$ Throughout, I use the term 'star' and 'celebrity' interchangeably. I maintain that celebrity studies offer scholars of hagiography a powerful heuristic framework with which to interrogate the construction of sanctity, and vice versa. In this, I am not alone: various critics suggest a parallel between modern celebrity and medieval sainthood. ${ }^{5}$ Medievalist Clarissa W. Atkinson, for example, declares that ' $[\mathrm{h}]$ oly persons - saints and ecstatics and miracle workers - were the celebrities of the Middle Ages'. ${ }^{6}$ In turn, cultural sociologist Richard Howells proclaims that we 'make saints of our celebrities today'. ${ }^{7}$ Historians often decry the inability to ever really access the 'real personhood' of a saintly protagonist. ${ }^{8}$ Representations of female holiness are, on the whole,

1 Griffith, p. 25. Cited in Dyer, Stars, p. 18.

$2 \quad$ VMOSupp, 1.2.667

3 P. 21. See also: Farmer, p. 221; M.H. King, 'Introduction', p. 37.

4 Turner uses the term 'celebritise' (p. 13), whilst Rojek prefers 'celebrification' (Celebrity, pp. 181-99). I use the terms interchangeably.

5 See in particular: Schmitt and Société d'ethnologie française.

6 'Female Sanctity', p. 226.

7 'Heroes', p. 126.

8 See, for example: J. N. Brown, 'Marie', pp. 247, 256; M. Brown, pp. 217-22; Grossel, p. 97; Lauwers, pp. 64-65, 80-81. 
constructed by male hagiographers who mediate 'direct' contact with their sources. This is a particularly acute problem when no other records, such as legal or historical documents, testify to the woman as a specific individual apart from a vita. Theorizing sanctity in terms of celebrity - the conscious fabrication of a 'special' identity through mediatization - permits us to move beyond such limitations.

In 1979, Richard Dyer provided a methodology for systematic study of celebrity production, identifying the constituents of the 'star image': 'promotion, publicity, films and criticism and commentaries'. ${ }^{9}$ The celebrity ('star image') is an inauthentic representation, fabricated from an amalgam of 'media texts' and grafted on to the real personhood of the star-as-subject. ${ }^{10}$ Although audiences readily grasp that a famous actor is not the character they play in a film, they do not - or do not want to - necessarily discern that the actor is not synonymous with their attached celebrity persona either. In fact, the 'true' identity of a celebrity is fragmented, pieced together by various attributes which together form a whole. When analysing celebrity, Dyer observes that 'we are dealing with the stars in terms of their signification, not with them as real people. The fact that they are also real people is an important aspect of how they signify, but we never know them directly as real people, only as they are to be found in media texts." ${ }^{11}$ The same is true for analyses of hagiography.

Medieval holy women exist to us solely in, and as, hagiographical 'star images'. Indeed, the majority of our knowledge of Marie of Oignies comes from Jacques' vita. It is 'impossible to know the real Marie' as 'she is buried under layers of Jacques's imposed meaning. ${ }^{12}$ Jacques could not make Marie out of thin air, but once he discovered her spiritual talent he could craft her image to fit his needs. Marie's celebrity lies in her extreme holiness, but her symbolic capital can be leveraged for both social and spiritual gain. ${ }^{13}$ The processes of celebrification entail a production of identity for specific aims. There is an inherent power disparity between producer and product, Jacques

9 Emphases in original; Stars, p. 68.

10 Ibid., p. 10; Heavenly Bodies, pp. 10-11.

11 Stars, p. 2.

12 J. N. Brown, 'Marie, p. 250.

13 I examine at length the various different portrayals, both medieval and modern, of the holy woman in: 'Marie of Oignies'. Manipulation of Marie's celebrity-image continues to this day, as the Walloon region of Belgium leverages her renown to draw in tourists. In 'Textual Authority', I discuss the usage of St. Birgitta of Sweden's (d. 1373) spirituality by the English, French, and Scottish during the Hundred Years War. My focus in the two pieces is on the given saint's socio-political 'capital', rather than celebrity. Nevertheless, the analyses in both are highly pertinent to my arguments here. 
and Marie. However, Jacques consistently positions himself as Marie's foremost follower, her number one fan. This occludes superficially the cleric's power as the producer of the holy woman's primary 'star image', her vita.

By casting himself as a fan, Jacques implies that he is subordinate to Marie's star power. However, fans are not simply passive consumers of the celebrity-objects with which they are presented. Fans are 'the theologians of a secular age'. ${ }^{14}$ They re-interpret and re-contextualize seemingly authoritative 'star images' to tease out new significations, based on specific circumstances and biases at play. In this context, Marie's pre-existing local fame which drew Jacques to Oignies originally functions as a 'star image' which Jacques, as a fan, can modulate to serve his own interests. Indeed, the cleric leverages Marie's fame in order to become a celebrity in his own right: a star preacher. This kind of stardom is not precisely identical to Marie's charismatic celebrity. Nevertheless, as a star preacher Jacques joins Marie in the VIP-suite reserved to the most illustrious movers and shakers in contemporary religious circles. Jacques is but one of Marie's fans, however. Other fans utilize Marie's star-texts for their own purposes, thereby remaking the holy woman's persona anew. In a later section, I explore one such alternate fabrication: English mystic Margery Kempe's (d. after 1438) fannish, and ultimately unsuccessful, usage of Marie to construct (and legitimize) her own status as a religious celebrity.

In positing Jacques and Margery as 'fans', I offer a counter-argument to numerous scholars' insistence that fandom emerged only in the eighteenthand nineteenth-centuries. ${ }^{15}$ This classification also develops Dyer's theory of celebrification, in which fans are dismissed as little more than passive consumers of celebrity-texts. ${ }^{16}$ Such passivity might have characterized the fans of Classic Hollywood (1917-1960) celebrity, the period in which Dyer grounds his analyses. However, largescale technological shifts in the years since have allowed fans to engage ever more directly with celebrities and fan-texts. ${ }^{17}$ The internet, for example, has facilitated the formation of fan communities, in which all aspects of a given 'star image' are dissected, discussed, and re-imagined in works of fanfiction. Web 2.0 has led to the

\footnotetext{
14 honestcoyote, n.p.

15 See, for example: Berlanstein; Braudy, pp. 380-89; McDayter, pp. 1-2, 23-28 (in particular p. 23); Morgan, pp. 101-10; Tillyard.

16 Dyer, Stars, p. 10. Other scholars similarly reject (implicitly or explicitly) Dyer's assertion(s). See, for example: Giles, pp. 128-46; J. Gray, Sandvoss, and Harrington; Huffer; Jenkins, 'Star Trek'; Textual Poaching; Fans; Sandvoss.

17 For a historical survey of fan studies, see: Jenkins, 'Panorama'.
} 
'fanification of everything'. ${ }^{18}$ Many of the creative practices first found in fandom subculture(s) have become mainstream. The rise of reality-TV and social media has also lead to the democratization of celebrity. These channels allow an individual to act as their own celebrity-producer, actively marketing their personality as the rationale for fame. ${ }^{19} \mathrm{I}$ examine this form of 'ordinary' celebrity in later sections focusing on Margery Kempe.

Celebrity - like sanctity - requires an audience, a collective that fabricates the celebrity-subject by dint of admiration. The reverse is also true. The fan existence is transitive: an object of attention is necessary for the construction of the subject position of 'fan'. ${ }^{20}$ Fan and celebrity are engaged in an act of mutual co-creation. As Jacques is 'much too human to be a saint', Marie is far too female to be a cleric, or indeed a hagiographer. ${ }^{21}$ Each contributes significantly to shaping the other's destiny. Marie is certainly instrumental in the development of Jacques' career. ${ }^{22}$ Under the holy woman's advisement, Jacques returned to Paris where he was ordained in 1210 by Bishop Pierre of Nemours (1208-1219). Returning to Brabant almost immediately, he officially associated himself with the priory of Oignies, adopting pastoral responsibilities. His personal and professional trajectory was now tied resolutely to the fate of the blossoming religious movement of lay Liégeoises taking up the vita mixta. At Marie's urging, Jacques undertook an extensive preaching campaign from 1210 to 1213. A year after Marie's death in 1213, Jacques was elected to the episcopate of Acre and by 1216 was active in the Holy Land and the Fifth Crusade. As early as 1215, Jacques composed Marie's vita, sharing her story with all of Christendom. After returning to Europe in 1226, he was promoted to the office of cardinal by Gregory IX (1227-1241) in 1229, and spent the rest of his life tending to matters of the curia. On the vigil of St. Philip and St. James in 1240, Jacques died in Rome. At his own request, he was buried in the church of Oignies, a foundation he had consecrated in 1227 and the resting place of Marie's relics.

According to Jacques' account, Marie, born to a noble family in Nivelles in 1177 , showed early signs of holiness. She disdained worldly goods and

18 Hassenger, n.p. On this, see in particular: Jenkins, 'Afterword', Convergence; Burgess and Green.

19 On this, see in particular: Biressi and Nunn, pp. 145-55; Cashmore, pp. 36-55, 188-207; Dovey; Edwards; Round and Thomas; Stefanone, Lackaff, and Rosen, pp. 107-12. On the impact of an 'ordinary' celebrity's gender on audience reaction, see: Williamson, pp. 118-20.

20 On this, see in particular: Sandvoss, pp. 95-122.

21 McDonnell, Beguines, p. 30.

22 For an in-depth biography of Jacques, see: Funk; von der Osten-Sacken, pp. 23-62. 
yearned to adopt the religious life. ${ }^{23}$ In dismay, her parents married her off at the age of fourteen to John, a man from Nivelles. Shortly after the nuptials, however, Marie managed to persuade her husband to take up a chaste union. ${ }^{24}$ After divine inspiration, John also agreed to the disposal of all the pair's worldly goods. The couple moved to Willambroux to tend the patients of a leprosarium and to serve the poor in extreme humility. Due to Marie's divine knowledge and exemplary holiness, she was constantly sought out to offer counsel and spiritual insight. ${ }^{25}$ Such was the demand that at times she had to hide in fields and forests to get some peace. ${ }^{26}$ Ultimately, such temporary escape was not sufficient. She was forced to move to a more isolated location, Oignies. ${ }^{27}$ Jacques' initial meeting with Marie occurs after this transfer: he is but one of a multitude of her fans.

After the publication of her vita, Marie was known beyond Brabant-Liège and the hagiographical genre. She was no longer a purely local star. The biography was widely disseminated throughout the medieval period, and became one of the most extensively circulated biographies of a thirteenthcentury holy laywoman. ${ }^{28}$ Susan Folkerts catalogues thirty-nine extant manuscripts which contain the vita, fragments, or adaptations. ${ }^{29}$ Twelve to fourteen of these originate in the period between 1215 and 1300, with the majority (seventeen or eighteen) produced between 1400 and 1525. The full vita was also translated into Dutch, English, French, Italian, Norse, and Swedish. Manuscript possession of the Latin vita bears witness to the large geographical range of Marie's text. Examples show ownership in institutions in England, Northern France, Germany, and the Northern and Southern Low Countries. Evidently, Marie's biography had enduring appeal, and knowledge of the holy woman spread via the text, increasing the sphere of her recognition for sanctity exponentially.

It is not necessary to have been a consumer of the star's primary output - film works, for example - to acknowledge their stardom. Supplementary texts also contribute to the wider appreciation of an individual as a celebrity. Such texts include: promotional documents for a given film; interviews; social media posts; gossip reports; and even a fan's own communication with friends about the celebrity. Reading a celebrity gossip magazine, for example,

$V M O, 1.1 .11-12.639-40$.

Ibid., 1.1.13-14.640.

Ibid., 1.1.14.640; 2.8.77.656.

6 Ibid., 2.5.47.648.

7 Ibid., 2.9.93.661.

More, 'Martha', p. 271.

29

Pp. 226-7, 230, 235-41. 
a reader may not know precisely who a star is, or have seen any of their films. Nevertheless, the reader recognizes that the star is famous because they are included in this forum. Another marker of Marie's celebrity is thus her inclusion in various non-hagiographical texts, signalling her status as a star (or star-text), appropriate to be drawn on by and for different audiences.

For example, Vincent of Beauvais (d. 1264) included large extracts of Marie's hagiography in his Speculum historiale, the third part of his behemoth encyclopedia (Speculum maius).$^{30}$ Over 240 manuscripts of this text remain, and it was translated into Flemish by Jacob of Maerlant (d. $c$. 1300) in 1280 and French in 1333 by Jean of Vignay (d. c. 1350). Dominican Thomas of Cantimpré (d. 1272) also referenced Marie in his spiritually didactic allegory based on the communal life of bees (Bonum universale de apibus, c. 1257-1263). ${ }^{31}$ This was another popular text, with eighty-six Latin manuscripts of the whole text extant. The text's wide audience is further revealed by its rapid appearance in print in $c$. 1473, the first of six Latin editions. The work's geographical reach is evidenced by translations into Dutch, French, and German. Marie has only a bit part in both Vincent and Thomas' collections, figuring as one of many individuals drawn upon for exemplary tales. Despite sharing the bill with other stars, as it were, her inclusion in such texts is noteworthy. It shows her acceptance as a holy woman of sufficient general esteem to be used as an authoritative source. Marie is a bona fide religious celebrity.

\section{An Anti-Cathar Poster Girl}

Marie was ostensibly a spiritual celebrity in Liège before Jacques made her acquaintance. What prompted Jacques to spread Marie's fame further, and why was his mission so successful? In the vita's prologue, Jacques explains that Bishop Fulk of Toulouse (d. 1231) requested that he undertake the composition of Marie's biography in order to provide material for antiheretical preachers in Fulk's own region. ${ }^{32}$ In the year of Marie's death, 1213, Jacques embarked upon preaching the Albigensian crusade. ${ }^{33}$ His staunch backing of Fulk's anti-Cathar agenda, displayed through the example of

$30 \quad 30.10-51.1240-125^{2}$.

$31 \quad 1.9 .8 .40 ; 2.55 \cdot 54 \cdot 5^{29--32 .}$

32 VMO, prol. 9.638. For analyses of Jacques' anti-Cathar strategy in the vita, see in particular: Kienzle, pp. 24-25; Kurtz.

$33 V M O, 2.9 .662$. 
Marie in the vita, surely fast-tracked his ecclesiastical career. The efficacy of the vita as 'an anti-heretical manifesto' ('un manifeste antihérétique') is directly linked to Marie's pedagogical utility as a celebrity. ${ }^{34}$ That is, she teaches other Christians how to behave, and why, by her own way of life. Jacques' description of Marie's acclaim in the community, however, must be regarded with suspicion, or at least caution. In the vita, Jacques' retroactive celebrification of Marie is a foundational element of his legitimizing agenda. He needs Marie to be widely regarded for great piety - famous - in order for her to stand as a worthy anti-Cathar model for others to take up. Her celebrification is a direct response to the 'craving' of the institutional Church for a persuasive representational image of orthodoxy for the laity, and particularly lay women, to venerate and follow. ${ }^{35}$

Although Jacques details Fulk's request for the production of the vita in the prologue, he dedicates the text to the bishop for different reasons: 'I am speaking to you and have dared to dedicate this little work to you because you, as my teacher, berated me because of my negligence. You know, I repeat, that when you came to our country, it seemed to you that you were in the promised land' ${ }^{36}$ Jacques conflates Fulk with the entire church, with the bishop identified as 'of the entire Church of Christ' ('imo totius ecclesiae Christi'). Thus, the vita is dedicated to the Church more generally, which has harboured suspicion for the mulieres religiosae. The vita affirms Fulk's surprised yet positive reaction to the Liégeoises, recording the affirmation for all to see, and thereby promotes the women as approved by the Church. Moreover, Fulk's need for an anti-Cathar poster girl inherently required a positive interpretation of the women's practices. Beguines were criticised for behaviour similar to that of the Cathars. ${ }^{37}$ Thus, Fulk's orthodox agenda facilitated and meshed with a defence of Marie and her spiritual colleagues. Behaviours which would exculpate the women would also serve as models for orthodoxy for others.

Celebrity, according to P. David Marshall, functions as 'a very elaborate morality tale that [maps] a private world onto a public world'.$^{8}$

34 My translation; Vauchez, 'Prosélytisme', p. 98. On the pedagogy of celebrity, see: Marshall, pp. 36-37.

35 Rojek, Fame Attack, p. 34.

36 VMOEng, prol. 2.41. '(ad te enim mihi sermo est, quo praecipiente \& de negligentia me redarguente, praesens opusculum ausus sum attentare) [...] inquam, quod cum venires ad partes nostras, jam tibi visum est esse quasi in terra promissionis'. VMO, prol. 2.636.

37 Lauwers, pp. 102-03; Simons, Cities, pp. 16-24; 120-21; 132-35. On the link between beguines and Cathars as heretic groups, see in particular: Ellis, pp. 171-72; Goodich, 'Contours', pp. 30-32. 38 P. 37 . 
The celebritized Marie functions as a blueprint for the self-production of her fans. Fulk required an orthodox female 'counter-model' because Catharism could particularly attract women, as it offered them positions of power at its highest echelons, the perfects. ${ }^{39}$ Perfects were the most spiritually pure, full participants in the Church and eligible for election to the office of bishop. The Cathar sacrament of the consolamentum was administered in the ceremony to become a perfect, and was the manner by which the devotee wrested back control from the Devil. This sacrament was allowed to both men and women. Initially, the heresy offered women a significant gain in power, as they became teachers and preachers. However, the Cathar hierarchy was eventually dominated by men. Fewer women than men became perfects and no woman ever attained the rank of bishop. Women were also more likely to be seduced by the heterodoxy due to a lack of sufficient space in and support for orthodox female religious institutions, to which the new form of devotion practised in Liège offered a solution..$^{40}$

The vita's anti-Cathar programme consists, in the main, of the promotion of: strict submission to clerical powers; the reality of purgatory; the importance of confession; the authenticity of the Eucharistic sacrament; and believers' triumph over demons. ${ }^{41}$ In this way, the text furnishes vivid orthodox counter-examples to central tenets of Cathar belief. The Cathar heresy was one of dualism, the belief that God originated all goodness, whilst evil was produced by an evil god. God fabricated the spiritual realm, whilst Satan was the creator of all earthly matter. Thus, the Church - as an institution of the world - was a diabolical institution. In comparison, Marie reveres the Church and its clerical representatives. She kisses and clutches the feet of priests, or sorrowfully cries, if they attempt to leave after giving sermons in church..$^{42}$ For the Cathars, the Devil - not God or the Church - was the chief organizing force in the world. The Devil and his minions were overwhelmingly powerful entities, nefariously shaping human life at every turn. Indeed, rather than purgatory being a transitory state after death as in the orthodox view, for Cathars purgatory equated to existence in the diabolical world. In countless visions, Marie, and thus

39 Kienzle, p. 25. On Cathar rites, see: Kurtz, pp. 187-88; Nicholson, pp. 54-56; Peters, p. 107; Simons, Cities, pp. 20-21. More generally on Catharism, see Lambert, pp. 105-46.

40 Kurtz, p. 187; McDonnell, Beguines, pp. 81-110.

41 On the rhetorical programme of the vita, see: Farmer, pp. 208-o9; Kurtz; Vauchez, 'Prosélytisme'.

$42 V M O, 2.7 .68 .654$. For similar examples, see: Ibid., 1.2.19.641, 2.7.68-69.654-55; VMOSupp, 1.2.667. 
the vita's reader, perceives that purgatory is an all-too-real state to which sinners are relegated after death..$^{43}$ The holy woman is also a vigorous demon slayer, and her many victorious episodes offer proof of the Devil's innate weakness. ${ }^{44}$

At other points in the vita, Marie's role as an anti-heretical figure-head is less subtle. She explicitly supports the Crusade against the Cathars, proclaimed by Innocent III (1198-1216; d. 1216) in 1209. She views dying as a crusader as the height of holiness, and yearns to be martyred herself. ${ }^{45}$ Marie's repeated visions depicting the immediate entrance of slaughtered crusaders to heaven, bypassing purgatory, shows the authenticity of the indulgence issued to crusaders. ${ }^{46}$ Jacques funnels messages of the Crusade's righteousness through divine revelation and prophecy. In his prologue, he identifies these specific attributes as targets of detractors who oppose the vita mixta pursued by the holy Liégeoises: "They [the detractors] extinguish the spirit the more it is in them, and they despise prophecies because they scorn spiritual people, thinking them insane or idiots, and they consider prophecies and the revelations of the saints to be fantasies or illusions of sleep..$^{47}$

By depicting pro-crusade prophecies and revelations, Jacques emphasizes that such channels of knowledge are legitimate, and fit within pious orthodox practice. A detractor cannot reject Marie's anti-heretical message without positioning himself as a heretic, or at the very least sympathetic to the Cathars' cause. As such, Jacques' celebrification of Marie is less outright manipulative. By constructing the holy woman as a model, he offers her up as a non-threatening orthodox Christian, glossing potentially troublesome behaviours in a decidedly positive light. Hagiographic fame offers Marie protection from ecclesiastical censure, at the same time as it robs her of personal agency. As with all those subject to the celebrity manufacturing process, Marie's 'enfranchisement and empowerment' is co-terminous with her 'exploitation [and] objectification'. $4^{8}$

$V M O, 1.3 .27 .643 ; 2.6 .51 .650 ; 2.6 .52 .650 ; 2.6 .53 .650-51 ; 2.12 .104 .664 ;$ VMOSupp , 2.12.670-71.

$44 V M O, 1.3 .29-30.643-44 ; 1.3 .31-32.644 ; 2.6 .50 .650 ; 2.6 .52 .650 ; 2.6 .58-60.652 ; 2.6 .61 .65^{2}-53$; $2.7 .70 .655 ; 2.9 .85 .658-59 ; 2.12 .108 .665$.

45 Ibid., 2.11.82.658.

46 Ibid., 2.11.82-83.658. See also Marie's explanation of purgatory to a former crusader, unworthy of martyrdom: VMOSupp, 1.4-5.668.

47 VMOEng, prol.10.50. 'Ipsi vero spiritum quantum in se est extinguunt, \& prophetias spernunt: quia spirituales quosque, quasi insanos vel idiotas despiciunt; \& prophetias sive Sanctorum revelationes, tamquam phantasmata vel somniorum illusiones reputant.' $V M O$, prol.10.638.

48 Turner, p. 13 . 


\section{Marie the Mystical Chanteuse}

The vita furthered the holy Liégeoises' cause to a certain degree. In a letter to Lutgard of Aywières in October 1216, Jacques relays that he received from Honorius III documents officially sanctioning communal living arrangements for beguines not just in the diocese of Liège, but across the whole Roman Empire. ${ }^{49}$ This good news is immediately undercut, however. Jacques continues that he is denied any special authority to defend the women, who are the subject of oppressive strictures virtually everywhere, with some even imprisoned. ${ }^{50}$ For this reason, Jacques does not plan to return and face the holy women's castigation: 'Indeed, if I were not able to protect them in the affairs which had been promised, they would not receive the message preached and, what is more, even spit in my face..$^{51}$ In order to save face and protect himself, the hagiographer allows himself that which he denies Marie: invisibility.

Marie exists in a textual panopticon. There is no way she can remove herself from the spectacle that Jacques stage-manages: she is explicitly billed as the star of the show. But the holy woman can, and does, pixelate the image, rendering her representation (spiritual value) at least partially unintelligible. For a period of three days and nights before her death, Marie belts out a mystical song..$^{52}$ Jacques confines her in text. In response, she communicates in a medium that cannot be lexically captured: music. Marie's song contains exceptional theological and religious knowledge, delivered with compelling persuasion..$^{53}$ Yet, none of her listeners can actually decipher its contents, nor remember it all. The vita records none of Marie's lyrics, nor the language in which the holy woman sings. Though communicative, Marie's anthem is beyond language - and thus out of Jacques' reach.

Mystical singing affords Marie a moment of resistance to clerical control. If clerics wish to interpret her song, they require her to translate it for them: she accedes to a form of knowledge inaccessible to men. Her performance

49 The first line of the letter has been lost, but the content suggests the same addressee as Jacques' second letter, identified as being sent to Lutgard: Huygens (ed.), letter I, p.74, 1l. 76-81; Sandor, p. 295. This is the same letter I reference above: Introduction, p. 29.

50 Huygens (ed.), p. 74, ll. 81-9o.

$5^{1}$ Translation from Wright, p. 156. 'aliter enim verbum predicationis non reciperent, sed magis in faciem meam conspuerent, si eos, secundum quod promissum est eis in predicationibus, protegere non valerem'. Huygens (ed.), p. 74, 1l. 87-90.

52 VMO, 2.11.98-99.662-63.

$53 V M O, 2.11 .99 .663$. 
equates to preaching, an activity normally disallowed to women. ${ }^{54}$ What's more, mystical preaching is enviably easier than traditional preaching:

She did not think [nec] about composing sentences, nor [nec] did she spend time arranging what she had composed rhythmically, but the Lord gave it to her just as if it had been written out before her at exactly the same time as it was spoken. She rejoiced with a continuous cry and did not have to [nec] deliberate over it, nor [nec] did she have to interrupt her song in order to arrange its parts. ${ }^{55}$

More than signalling Marie's talents, this pile of negations - in the form of asyndeton of 'nec' - highlights the difficulties normally faced by a preacher, difficulties Jacques himself must surely have faced. Additionally, Marie's marathon session of preaching is a feat that a preacher, lacking in divine vitality, could never dream of completing.

As Marie steals the show with her singing, Jacques tries to rush the stage. He attempts to interrupt Marie's moments of personal devotion with his own singing. With a group of colleagues, Jacques sings liturgical chants loudly in church next to Marie, 'almost directly in her ears' ('quasi ad aures ejus').${ }^{6}$ His vocalizations cannot break through Marie's spiritual aura, nor can they relate the kind of intense spiritual experience which characterizes her singing. The vita frames this moment as an example of the woman's staunch piety: she is 'untroubled' ('numquam aliquo tumultu gravari poterat') by any sounds which relate to the Lord. The exemplarity of Marie's reaction veils Jacques' frustration at the impotence of his music to disrupt her spirituality. He even hires stonemasons to erect an altar right beside her, in the hopes that their clattering hammers will do the job. ${ }^{57}$ The holy chanteuse, however, just won't quit: Jacques' inglorious hopes are dashed.

Earlier in the vita, Jacques laments the inferiority of the human senses, to which he himself is constrained, in comparison to Marie's heightened

54 Muessig, 'Prophecy', pp. 146-58; Wiethaus. For other examples of female mystical singing in the corpus, see: VCM, 3.35-37.656; VLA, 1.2.18.241; VILov, 1.2.11.161; 2.3.13.174; 3.5.25.188.

55 VMOEng, 2.11.98.119. 'nec deliberabat an sententias inveniret, nec morabatur ut inventas rithmice disponeret; sed velut ante se scriberentur, dabat ei Dominus in illâ horâ quid loqueretur. Continuo clamore jubilans, nec in cogitando laborabat, nec in disponendo cantum interrumpebat.' $V M O, 2.11 .98 .662$.

56 VMOEng, 2.12.105.123-24; VMO, 2.12.105.664.

57 From another perspective, Jacques' 'frustration' could be viewed as satisfaction. The inability to disrupt Marie's song emphasizes her extraordinary holiness, from which he profits. 
spiritual senses. ${ }^{8}$ Marie's direct connection to the Lord - rendered audible by her song - is superior to a more rational link to Him. Jacques needs Marie. She alone has the gift of a direct connection with the divine, a link which he cannot forge for himself without her mediation: 'he preaches, and she makes contact with God'.59 Whilst Jacques has 'earthly control' over Marie's 'spiritual self', the reverse is also true. ${ }^{60}$ To produce a vita of a holy individual to further his own concerns, Jacques needs a religious figure that he can reshape. Marie, however, does not need Jacques to access God: access to the Lord is her ultimate talent, her ' $\mathrm{X}$ factor'.

It is rather fitting that Marie's ' $\mathrm{X}$ factor' is most clearly on display during her mystical choral performance. The property of escaping precise characterization is central to the ' $\mathrm{X}$ factor'. You can't describe it, but you know when someone has it. This is literally true for Marie's unintelligible mystical song. In addition, the wildly popular TV talent competition The $X$ Factor has staged the celebrity manufacture process for audiences across the globe for over a decade. ${ }^{61}$ The TV talent competition has reinvigorated the signification of the phrase ' $\mathrm{X}$ factor' as the fundamental ingredient in celebrity creation. For X Factor contestants, as for Marie of Oignies, singing talent is central to their celebrification. It's how they make it onto the TV stage, and the one bargaining chip they have in the celebrity industrial complex.

\section{Jacques of Vitry, Star Preacher}

Writing the vita, Jacques engages in an act of self-production as much as he constructs a specific image of Marie as authentically holy. As Jennifer N. Brown asserts: '[i]n many ways the life of Marie [of] Oignies is not about Marie at all. [Jacques of Vitry] is omnipresent throughout the text, inserting himself both overtly and surreptitiously into nearly every aspect of Marie's life. ${ }^{62}$ Jacques consistently positions himself as benefiting from the reflected glow of Marie's spirituality, not just as Marie's most devoted fan but also as an intimate member of the holy woman's VIP entourage. The privileged access that this affords Jacques ultimately propels him into stardom in his own

$5^{8} \quad V M O, 2 \cdot 7.66 .654$.

59 Coakley, p. 8 o.

6 o J. N. Brown, 'Erotics', p. 88.

61 For an analysis of the commercial strategy of TV talent shows, see: Jenkins, Convergence, pp. 59-93.

62 'Marie', p. 247. 
right. He garners a host of his own fans who follow him and (re)construct his identity, claiming him as a celebrity preacher.

Marie is miraculously present at the ordination of 'one of her dearest friends' ('amicus sibi carissimus'), implicitly Jacques himself. ${ }^{63}$ She fills letters to him with prophetic messages which he cannot yet understand, including reference to the spiritual blossoming of a tree destined for her. The text immediately shifts to remark that Marie was present at the priest's first celebration of mass. Moreover, just before these comments, Jacques emphasizes that Marie is endowed with potent spiritual sight as to the worth and devotion of priests. Jacques thus highlights his own excellence as a cleric. Earlier in the vita Marie is shown praying to God for a preacher, as she herself cannot evangelize. ${ }^{64}$ This directly links the 'anonymous' Jacques' ordination to Marie's request: he is literally a gift from God. This clearly elevates Jacques' status above other clerics whose career has not been divinely appointed. The hagiographer leverages the holiness, and reputation for prophetic insight, that he so carefully establishes for Marie in order to authorize his own reputation.

Elsewhere in the vita, we learn that Marie's preacher 'conferred virtue by bodily labour, ministered the word, directed her steps, and arranged his sermons for his audience in an agreeable and beneficial order through the merits of the handmaid of the Lord'. ${ }^{65}$ This sentence foregrounds the reciprocal dynamic at play between hagiographer-fan and saint-star. As the vita's all-powerful author, and in 'real' life as a trusted clerical advisor, Jacques metaphorically and perhaps literally 'direct[s]' Marie's movements. He 'arrange[s]' the basic biographical material she provides into an 'agreeable and beneficial order' to generate a representation of acceptable holiness. Marie's religiosity, however, is responsible for Jacques' skill in preaching, as she channels God's grace to her acolyte. God speaks to Marie, Marie speaks to Jacques, and he then transmits powerful religious truths to the audiences of his sermons. Jacques' position in this divine telephone game - at only one remove from God Himself - gives his sermons an enviable theological weight, and is central to his own celebrity identity. Indeed, Dominicans Humbert of Romans (d. 1277) and Etienne of Bourbon (d. c. 1261) proclaim

$63 V M O, 2.9 .86 .659$.

64 Ibid., 2.7.69.654-55.

65 VMOEng, 2.7.69.99. 'sanctae mulieris precibus compraeparabat, virtutem corporis in labore conferebat, verbum ministrabat, gressus dirigebat, gratiam \& fructum in auditoribus meritis ancillae suae praeparabat'. $V M O$, 2.7.69.655. For Marie's positive influence on Jacques' preaching, see also: $V M O, 2.8 .79 .657$. 
Jacques the best preacher France has ever seen. ${ }^{66}$ Promulgating God's words was central to the Dominicans' mission and their identity - after all, they were known as the Order of Preachers (Ordo Praedicatorum). As such, the acclaim heaped on Jacques by Humbert and Etienne, notable figures in the Order, demonstrates his transformation from humble hagiographer into an ecclesiastical celebrity. Jacques is the preacher's preacher.

Testimony as to the power of Jacques' preaching is provided in the supplement to Marie's vita, written in $c .1231$ by Thomas of Cantimpré. The short work ostensibly provides additional details as to Marie's piety, and the special bond between the holy woman and her original hagiographer. In actuality, the Supplementum reveals far more about Thomas' intense admiration for his mentor, Jacques. ${ }^{67}$ Thomas comes across as the older cleric's own superfan, by turns establishing and bearing witness to Jacques' celebrity. In the final chapter, the author addresses Jacques directly:

With what charity I love you, with what sincere love I embrace you, he knows who knows all things [ipse novit, qui omnia novit]. When I was not yet fifteen years old and you were not a bishop, I heard you preaching in Lotharingia. I loved you with such veneration that I was happy just at the sound of your name. From then on a special love for you stayed with me. ${ }^{68}$

As Jacques sought out Marie during his youth, an adolescent Thomas was drawn to Jacques. The preacher's fame, accrued thanks to Marie's guidance and the utility of her as an example, travels across the land dissociated from Jacques himself. Thomas would be overjoyed just to hear Jacques' name, the signifier not of Jacques as a 'real' individual but of a celebrity evangelist. Moreover, Thomas' extreme admiration for Jacques lies not in the fact that he knows all, but he knows the people who know all ('ipse novit, qui omnia novit'). Jacques' ability to tap into this spiritual body of knowledge through Marie marks him out as a celebrity in Thomas' eyes. Whilst Jacques taps into Marie's spiritual powers, using her particular talents to enhance his

66 Respectively: Boyer (ed.), ex. 4, prol..4.37-42; Quetif and Echard (eds.), p. 186. See also similar comments from the sixteenth century: Trithemius, 432.106-07.

67 J. N. Brown, 'Erotics', p. 75, n.3; Roukis-Stern, pp. 42-43.

68 VMOSuppEng, 4.27.164. 'Qua enim caritate vos diligam, quam sincero vos amore complectar, ipse novit, qui omnia novit. Nondum enim annorum quindecim aetatem attigerem, cum vos necdum Praesulem in Lotharingiae partibus praedicantem audiens, tanta veneratione dilexi, ut me solius nominis vestri laetificaret auditus: ex tunc mecum vestri amor individuus perseverat.' VMOSupp, 4.27.676. 
reputation, Thomas wishes to emulate his idol almost identically as author and churchman. The latter choice is much more orthodox than the intimate relationships Jacques cultivates with the holy Liégeoises. Thomas does not want to be religiously omniscient, but wants to know such a figure and tap in to their spiritual knowledge base. He wants to be friends with a member of a celebrity's entourage, rather than be in the entourage himself.

Thomas follows in Jacques' footsteps, including authoring the vitae of other spiritual stars from the diocese: Margaret of Ypres, Christina Mirabilis, and Lutgard of Aywières. ${ }^{69}$ Indeed, in the prologue to Christina's vita, Thomas cites Jacques' description of the holy woman from the prologue to Marie's vita. ${ }^{70} \mathrm{He}$ draws on Jacques as a source, at least in part because Thomas never met Christina himself. ${ }^{71}$ This chain of connection to Marie-as-celebrity is potentially infinite: an individual who venerates Thomas gains some form of starstruck interaction with Jacques, and thereby Marie. Jacques (fan) constructs a specific image of Marie (celebrity), which leads to his own celebrification, and the acquisition of a fan of his own (Thomas). Theoretically, Thomas too could become a celebrity by tapping in to the potent system of representation in which Jacques and Marie exist. Thomas-as-celebrity could then be the object of fan attention, processed and reprocessed according to the specific desires and biases of his acolytes. The process of celebrification could continue ad infinitum.

\section{Hairdressers to the Stars}

Thomas of Cantimpré's celebrification remains theoretical, however. He is simply not as savvy in this business we call (religious) 'show' as his idol, Jacques. Thomas' professional performance is sub-par, to put it kindly. Whilst Jacques died a cardinal, Thomas ascended the ecclesiastical ladder only to the role of subprior in his Louvain institution. A fan (Jacques) in intimate contact with the star-object (Marie) can become a star in their own right, albeit a star of a lesser calibre. But a subsidiary fan (Thomas) of a first-string fan (Jacques) cannot. This dynamic is perhaps best illuminated by analysis of a modern example of the changing fortunes of a member of a modern celebrity's entourage.

$69 V M Y, V C M, V L A$ respectively.

$70 \quad V C M$, prol... $650 ; V M O$, prol..8.638.

71 J. N. Brown, 'Astonishing Piety', p. 219. 
In 1999, hairstylist Ken Pavés started his working relationship with American singer, actor, and reality-TV star Jessica Simpson..$^{2}$ The publicity generated by tending Simpson's tresses, and the pair's widely reported close bond, has catapulted Pavés into the hairdressing big leagues. He is frequently hailed as the 'man behind the best hair in Hollywood', with a roster of A-list clients with whom he is photographed on various red carpets. ${ }^{73}$ Pavés is no longer 'just' a stylist: he is a brand in his own right. From his debut on-screen appearance in Jessica Simpson: A Public Affair, a short documentary about Simpson's fifth album in 2006, Pavés has become a regular on the American talk-show and reality-TV circuit. Featured as a 'celebrity stylist', he demonstrates his skills by making-over members of the general public. Such appearances trade directly on the hairstylist's VIP connections, foregrounding his membership of Simpson's entourage and his key role in the creation of Simpson as a bona fide celebrity.

In Pavés' own words: 'It was under my direction that we took Jessica Simpson from her trademark blonde to the perfect auburn red that was inspired by Norma Jean Baker before she went blonde and became Marilyn Monroe. ${ }^{74}$ The hairdresser here characterizes the end-result of his careful coiffing of Simpson's image as resulting in Norma Jean, and not Marilyn. This is the reverse trajectory that one might expect when processing a female celebrity, given Monroe's mega-stardom. The point, however, is the transformation which takes place: from raw material to celebrity icon. Pavés' reference to the two personas - the 'before' of Norma Jean, and the 'after' of Marilyn - serves to draw attention to the conscious effort of celebrity manufacture, and his own role in guaranteeing a successful outcome. What's more, the seeming authenticity of the 'real woman' represented by Norma Jean Baker arguably fits the late twentieth- and twenty-first century palate for more approachable and accessible stars, fuelled by reality-TV and social media. The point being, today's 'Marilyn' is actually 'Norma Jean', at least in some quarters. Certainly, working with Simpson progressed Pavés' career. In much the same way, Jacques of Vitry's professional and authorial success is grounded on his relationship with Marie of Oignies. But, as with the hagiographer-holy woman relationship, the power between stylist and celebrity-client flows both ways. Pavés' careful sculpting of Simpson's image was central to her success, at least in his account. Under his tutelage, then, even an average Jane can become a star. Women of the world, take note. 
The stylist's capacity to (re-)fashion the 'star image' from the grist of biology and biography is plainly hagiographic.

Pavés has parlayed his access to authentic celebrities into the opportunity to ascend the ranks of (reality-TV) stardom himself. In 2010, for example, he appeared 'as himself' in the documentary-reality series The Price of Beauty, sharing equal billing with Simpson as one of the actor's 'best bud[s]'.75 The 2013 publication of his book You Are Beautiful, coupled with the launch of his own range of beauty products at Walmart shortly thereafter, cemented Pavés' status as a celebrity commodity. Let's be clear: Pavés is no A-lister. Celebrified primarily as an attendant to one of the 'real' stars, he can only be a C-lister, at best. He is not - and cannot - encroach on Simpson's territory as a pop singer or actor. Instead, he is a 'star' in the rather more banal realm of reality- and lifestyle-TV. Simpson is not an A-lister either, a status usually conferred on Oscar-winning actors and uber-successful entertainers. Nevertheless, in the public imagination, she is a 'legitimate' celebrity because her exposure is a by-product of her singing and acting activities. Like Pavés, Jacques of Vitry is not a holy A-lister (saint) himself; the best he can do is get up close and personal with a real star, Marie of Oignies, and leverage the reflected glow. But Pavés and Jacques are on the list, and that's what counts.

As a talented hairdresser, Pavés transformed Jessica Simpson from a relative unknown into a proxy for one of the greatest celebrity icons of the media age, Marilyn Monroe. He is thus allowed a share of the limelight. But fame only radiates so far. Who cares who Pavés' own hairdresser is? Nobody. This anonymous soul is not worthy of our attention, as his connection to the 'real' stars is so tenuous: Pavés' hairdresser touches the hair of the man who touches the actually 'important' hair. Marie of Oignies was certainly blessed with 'important' hair. Her locks are repeatedly figured as powerful healing relics, capable of infusing even the sickest wretches with vitality. ${ }^{76}$ Marie's strands, 'reposing with dormant power' ('virtute sopita [...] conquievit') even when shorn from her head, operate as a metonym for the holy woman's potent religiosity. ${ }^{77}$ In much the same way, Jessica Simpson's glamorous coiffure functions symbolically for her celebrity.

In his twinned roles as Marie's spiritual adviser and hagiographer, Jacques of Vitry gets his hands on the holy woman's hair, i.e. her spiritual identity.

75 Ibid., p. 9, p. 36; quote from p. 30.

$76 V M O, 2.6 .55 .651,2.8 .79 .657$; VMOSupp, 1.6-7.668-69. See also hair as a marker of the miraculous in: VLA, 2.23.249. On hair and hirsutism in female hagiography, see: Easton, pp. 337-40. On hair as a sacred artefact in contemporary culture and the global marketplace, see: Chidester.

77 VMOSuppEng, 1.7.146; VMOSupp, 1.7.669. 
He detangles the knots of heterodoxy from her religious praxes in order to craft a polished 'do, palatable to even the most discerning clerical stylists. By contrast, Thomas of Cantimpré's sole connection to Marie of Oignies is through Jacques. In the Supplementum, he metaphorically coifs Jacques carefully managing his idol's image - rather than meaningfully contributing to Marie's 'star image'. The question is: who cares about the hagiographer's hagiographer? Indeed, Thomas exits stage left the annals of hagiographical miscellany, at least in terms of his supplement to Marie's vita. The Bollandist editor of the work, Daniel Papebroeck (d. 1714), misidentified the author, listing an unknown Nicholas of Cantimpré instead of Thomas. ${ }^{78}$ Despite his attempts to leverage Jacques' stardom, Thomas remains for all intents and purposes a 'nobody' here.

A layer of nuance is needed: Thomas is not a 'nobody' everywhere. Whilst he is not a star hagiographer, Thomas's talents in other arenas are nevertheless recognized, at least in contemporary scholarship. The New Catholic Encyclopedia, for instance, presents Thomas first and foremost as a renowned encyclopedist, with his stint in hagiography an authorial side-line to be glossed over. ${ }^{79} \mathrm{~A}$ single sentence notes the five hagiographical works which Thomas authored. By contrast, two paragraphs are devoted to an exposition of his encylopedic texts, De natura rerum (On the Nature of Things) and Bonum universale de apibus (Book of Bees). ${ }^{80}$ The difference in space accorded to the two genres is implicitly presented as a logical choice to the reader. After all, 'Thomas's fame [...] rests especially' on his encylopedias. ${ }^{{ }_{1}}$ It turns out the hagiographer's hagiographer has hidden depths, a special talent not (fully) expressed in his current career cranking out spiritual biographies. But in the world of the medieval encyclopedia, he may just be king. In this world, it is entirely plausible that Thomas operates as a celebrity in his own right. That is: as an object of veneration by less talented or less successful writers, who utilize him as a model for the production of their own star image and textual outputs. Thomas cannot equal, or even usurp, Jacques of Vitry's celebrity status in the arena of hagiography. ${ }^{{ }_{2}}$ However,

78 Commentarius praevius, 3.19.634; VMOSupp, author attribution beneath title, p. 666. Appelmans, p. 179 .

79 Vansteenkiste, p. 32 .

8 o Ibid., pp. 32-33.

81 Ibid., p. 32 .

82 In terms of entries in the New Catholic Encyclopedia, Jacques of Vitry is actually accorded less space than Thomas of Cantimpré: $c 37$ lines to $c .48$ lines respectively (McDonnell, 'Jacques of Vitry'; Vansteenkiste). This does not reflect an implicit favouring of Thomas over Jacques as a figure worth more attention. Jacques' entry covers significantly more ground than Thomas's, 
there's everything to play for if the competition is re-staged to account for a different talent, and undertaken in a different arena (textual genre).

\section{Celebrity Role-Models}

The genre of celebrity reality-TV, such as The Price of Beauty, cannibalizes its headliners' pre-existing identity as a celebrity object. Pavés simply does not have the cachet to carry the show on his own. In Price, Simpson and Pavés, along with another of Simpson's long-time friend-attendants (Kacee Cobb) travel the globe to discover the punishing beauty standards of various cultures. Price is appealing to viewers not because of its social-justice-lite message, but because Simpson (a real star!) is the one who purportedly 'uncovers' the problems of female body-policing. The actor's pre-existing star identity makes the whole project viable. Furthermore, Simpson's involvement underscores that this is a problem worthy of attention. Medieval exempla, as Jacques Berlioz and Colette Ribaucourt point out, constitute 'an image, or a series of images' ('une image, ou une suite d'images'), reproducing metaphorically the Church's desired behaviour for the laity. ${ }^{83}$ In Price, Simpson adopts the role of an exemplum: she discovers that beauty is a social construct, thereby educating her audience. In place of the Church's metaphorical 'series of images', TV producers present the audience with a literal image sequence (TV show) in order to shape attitudes. As a piece of docu-tainment, Price is explicitly instructive. However, the infusion of documentary into the celebrity mix merely overlays a key tenet of stardom more generally: innate ideological potency. As stars 'relate to ideas about what people are (or are supposed to be) like', they are always exemplary figures to some extent. ${ }^{84}$

Simpson's horrified reaction to pernicious beauty standards is exemplary in The Price of Fame because she is a beautiful woman herself. She manages her looks assiduously - but even she won't do that. Moreover, as a female star she operates in an environment that subjects female bodies to even more punitive strictures regarding appearance than those to which non-famous women are compelled to conform. In Price's first episode, Simpson sets

which focuses primarily on his two encyclopedias. In sum: there is less to say about Thomas's life, career, and the impact of his works, which allows for a more leisurely paced exposition in the Encyclopedia entry.

83 My translation; p. 96.

84 Dyer, Stars, p. 22. See also: Cashmore, p. 70. 
herself apart from normal women: 'It's one thing to have insecurities, but when you have the whole world watching, and people are criticising you on top of it, it just can get to the point of being too much. ${ }^{85}$ Such statements emphasize the exceptional status of celebrity, a distinct socio-cultural role which is unavailable to most people. This exceptionality is also a hallmark of hagiographic protagonists.

Whilst holy women are sources of accessible inspiration to mould believers' behaviours, not everyone can achieve their levels of holiness. Practices upon which the celebrity identity is founded - Simpson's rigorous beauty regime or Marie of Oignies' intense asceticism- cannot, and should not, be practised by all and sundry. ${ }^{86}$ After graphically detailing Marie's selfmortifications, Jacques of Vitry emphasizes that readers should not emulate the holy woman: 'I do not say these things to commend the excess but so that I might show her fervour. [...] Therefore, admire rather than imitate what we have read about the things certain saints have done through the familiar counsel of the Holy Spirit. ${ }^{87}$ Not everyone can be a religious star. But every audience-member can reflect on the underlying message of such acts, and improve their own lives accordingly. Even holy women can take things too far. Jacques remarks that Marie 'abased herself to an extreme degree and afflicted herself - as it sometimes seemed to us - beyond measure. ${ }^{88}$ The mechanisms by which a star might manufacture holiness, even those based on physical performance, are strictly controlled by hagiographical producers.

Though Price's success is founded on Simpson's celebrity, the show supports her celebrity persona. Simpson is in Price because of her fame as a singer-actor; Price further evidences Simpson's fame. This feedback loop between primary (Simpson's film and singing career) and derivative (reality-TV appearances) star-texts in the creation of the celebrity identity is also evidenced in Marie of Oignies' textual corpus. Details from Marie's hagiography (primary text) circulated widely via inclusion in collections of exempla and resources for preachers (derivative works). For example,

85 'Thailand' (first aired 15 March 2010).

86 For Marie's fasting and associated ascetic food practices, see: $V M O, 1.2 .23-25.642,2.5 .44 .648$, $2.7 .65 .6542 .11 .97 .662,2.12 .105 .664 ; 2.12 .107 .665$.

87 VMOEng, 1.1.12.54. 'Nec hoc dixero ut excessum commendam, set ut fervorem ostendam. [...] Quod ergo quosdam Sanctos ex familiari consilio Spiritus sancti fecisse legimus, admiremur potius quam imitemur.' $V M O$, 1.1.12.639-40 On Jacques' critique of Marie's asceticism, see :J. N. Brown, 'Marie', p. 28o-81; Hollywood, p. 47.

88 VMOEng, 2.7.65.97. '[...] valde seipsam nimis abjiciens, \& supra modum affligens, nobis aliquando videbatur.' $V M O, 2.7 .65 .654$. See also: Marie's shame at immoderately cutting her own flesh $(V M O, 1.2 .22 .641-42)$. For other reprimands for self-mortification, see: $V B N$, 1.4.26.30-32; VJC, 1.1.4.445. 
episodes from her vita are reproduced by a variety of Dominican authors, including Etienne of Bourbon, Humbert of Romans, and Jean Gobi Junior (d. 1350). ${ }^{89}$ All of these works were targeted at a wide audience, indicated by references in prologues. ${ }^{90}$ Marie's appearance in these texts significantly increased her sphere of renown, and shored up her pre-existing identity. Simultaneously, the power of the exemplum lies in Marie's widely acknowledged status as a pious holy woman.

Ken Pavés was instrumental in fabricating Jessica Simpson's celebrity identity. That earns him a spot onscreen in The Price of Beauty. Likewise, Jacques of Vitry routinely crops up as Marie of Oignies' co-star in exempla anthologies. For example, Marie is the subject of ten exempla in Arnold of Liège's popular encyclopedic collection, the Alphabetum narrationum (composed 1308-1310)..$^{91}$ Jacques' name ('Iacobus de Vitriaco') features in the opening to all of these vignettes. This serves to flag Arnold's source material. But, it also means that in a very literal sense we encounter Marie through Jacques. The hagiographer's primary position undercuts Marie's leading lady role.

\section{Margery Kempe's Fanfictions}

Jacques intended for Marie's vita to be a model for religious lay women, but how did this function in actuality? The Book of Margery Kempe, composed in the 1430s, offers some answers. In the Book, Marie - and specifically her pious tears - is invoked as a blueprint, or legitimizing antecedent, to Margery's near perpetual weeping, which irritates and incenses those around her. In this way, Margery attempts to co-opt Marie's established celebrity in order to offer proof of her own extraordinary holiness, and thus sanction her own celebrification.

89 Etienne of Bourbon: TPP, ex. 174, 1.5.175.1037-47; ex. 175, 1.5.175.1047-55, 175; TPT, ex. 1028, 3.4.118-19.792-807; ex. 1072, 3.5.190-91.313-17; ex. 1083, 3.5.195.434-37; ex. 1094, 3.5.201.574-76; ex. 1137, 3.6.228.456-63; ex. 1218, 3.7.290-91.774-803; ex. 1283, 3.7.347.2270-o9; ex. 1313, 3.7.374-77.29433033. Humbert of Romans: Boyer (ed.), ex. 124, 5.91.162-66; ex. 144, 5.100.377-81. Jean Gobi: de Beaulieu (ed.), ex. 88, p. 202 ; ex. 945, pp. 617-18 (implicit). Jacques also used his vita as a source for exempla material in later works: Hinnebusch (ed.), Historia occidentalis, 38.207; drawing from $V M O, 2.12 .105 .664$.

90 Berlioz and Beaulieu, pp. 283-84. See, for example, TPP, prol..3-4,1-40; specifically ll. 6, 21 on p.3.

91 Arnold of Liège, Alphabetum, ex. 21, p. 16; ex. 145, p. 85; ex. 193, p. 112; ex. 249, p. 146; ex. 435-36, pp. 246-47; ex. 6o2-03, p. 333; ex. 676, p. 377; ex. 796, pp. 441-42. 
The Book of Margery Kempe is typically categorized as 'the first autobiography in English..$^{92}$ However, the Book is above all a literary work, not a straight-forward retelling of historical 'fact', however personal it may seem. ${ }^{93}$ In this respect, the Book is a typical work of hagiography. Furthermore, the text's status as 'autobiography' is ambiguous at best. For example, the Book is almost exclusively in the third-person: Margery is most often referred to as the creature ('creatur'). ${ }^{94}$ Additionally, two scribe-amanuenses are identified in the text, who work on the contents in two distinct tranches. ${ }^{95}$ Though these men are not explicitly named in the Book, a variety of circumstantial evidence leads to the prevailing scholarly assumption that Margery's son initially took on the role, which was later fulfilled by her confessor Robert Spryngolde. ${ }^{96}$ The division of authorial labour entailed in the Book's production is simply not clear. Critics have engaged with this instability in different ways. Ruth Evans, for instance, troubles the belief in any single identifiable author. ${ }^{97}$ Katherine J. Lewis considers the text a 'cooperative production' between clerical scribes and a woman whose narrative may not be wholly accurate.$^{98}$ By contrast, A.C. Spearing argues that Margery's second scribe was clearly the chief authorial force, and as such the Book could more accurately be called 'The Book of Robert Spryngolde, about Margery Kempe'.99 Barry Windeatt raises the possibility that the figure of a male (co-)writer is deployed as a protective trope in order to cloak a female authorial voice and thus avoid censure.$^{100}$ Similarly, the character of 'Margery' could potentially be a complete fiction constructed by 'Kempe', a female writer who need not necessarily be a holy woman. Lynn Staley systematically enacts a functional delineation between 'Margery, the subject, and Kempe, her author'. ${ }^{101} \mathrm{I}$ favour Staley's schematic, and follow her usage in all discussions below.

We know little of Margery's life apart from the Book's contents, which recounts both the steps the woman undertook to become an individual of

92 Staley, Fictions, p. 1.

93 On this, see in particular: Voaden, pp. 112-15.

94 For the sole usage of the first person, see: $M K B, 2.10 .660-800.230-34$.

95 Ibid., proem. 113-129.21. For Margery's collaboration with the scribe, see: ibid., proem. 9899.20, 1.89.5207-46.205-06.

96 For reference to Spryngolde as Margery's confessor, see: ibid., 1.26.1392.69; 1.57.3285-86.137. On the identification of the two scribes, see in particular: Sobecki; Spearing, pp. 92-93; Windeatt, 'Introduction', in Annotated Edition, pp. 5-8.

97 Pp. 507-10.

98 P. 195, n. 3 .

99 'Margery Kempe', p. 93.

100 'Introduction', in Annotated Edition, p. 6.

101 Fictions, p. 3. On this, see also: p. 1-38. 
superior spirituality and her role as a mouthpiece for God (and other divine figures) with whom she conversed in visions. Margery was born $c .1373$ in Bishop's Lynn (now Kings' Lynn) in Norfolk to an eminent burgess father. She married the burgess John Kempe in $c .1393$, and went on to have fourteen children. Margery outlived John, who died $c$. 1431, by at least seven years. In mystical visions, she witnessed the births of the Virgin Mary, John the Baptist, and Christ, amongst other notable biblical moments. She travelled widely across England and beyond, including undertaking divinely ordained pilgrimages to Rome, Santiago, and Jerusalem. Contemporary responses to Margery were mixed, to put it mildly. On her journeys, for example, she was arrested as a heretic in Leicester and in Hessle, and was ordered from the diocese of Cawood by the Archbishop of York. As Antony Goodman diplomatically summarizes: 'some regard[ed] her as a genuine mystic, others as a public nuisance, a charlatan, or diabolically possessed. ${ }^{102}$

The Book's usage of Marie provides 'concrete evidence' of the Liégeoise's religious celebrity. The holy woman was acknowledged as an apposite example for lay religious women across Europe in the later medieval period. ${ }^{103}$ Several English-based manuscripts testify to the dissemination of Marie's hagiography in England in the medieval period from as early as the thirteenth century. ${ }^{104}$ Marie's hagiography was translated into Middle English, a version left to us in only one manuscript, produced $c .1450{ }^{105} \mathrm{In}$ addition, Roger Ellis suggests that Marie's tale could have reached an English audience via excerpts from Vincent of Beauvais' Speculum historiale and the exempla contained in Arnold of Liège's Alphabetum narrationum. ${ }^{106}$ Kempe's account of reading Marie of Oignies' tale, then, could be truthful. Moreover, Kempe's reference to Marie of Oignies is not entirely spurious. Several key elements of Margery's life mirror Marie's. ${ }^{107}$ For example, both were married and persuaded their spouses to shift to a chaste union. Scholars such as Carolyne Larrington and Naoë Kukita Yoshikawa have demonstrated that

102 P. 222.

103 Atkinson, 'Female Sanctity', p. 226. On this, see also: J. N. Brown, 'Introduction', p. 21.

104 The full text of Marie's Latin vita is found in London, BL, MS Harley 4725 (thirteenth or fourteenth century), and Oxford, St. John's College, MS 182 (C8.55) (fifteenth century). Oxford, BodL, MS Bodley 240 (SC 2469) (fourteenth century) incorporates excerpts from the work. A fragmentary inventory from the fifteenth century suggests another Latin example, now lost: Book List, London, BL, MS Sloane 3548, fol. $158^{\text {r }}$ J. N. Brown, 'Introduction', pp. 13-14; Folkerts, pp. 226, 237; Kurtz, pp. 186-87.

105 Seint Mary of Oegines, Oxford, BodL, MS Douce 114, fols. $26^{\mathrm{v}}-7^{\mathrm{r}}$. For the critical edition, see: VMOME.

106 Ellis, 'Scribe', p. 169-70.

107 On this, see: Windeatt, 'Introduction', in MKBEng, pp. 19-20. 
Margery's spirituality was almost certainly shaped by Marie's example, including the format of the Presentation scene beheld in a vision, and her belief in the medicinal power of the Eucharist. ${ }^{108}$

Nevertheless, the Book foregrounds one parallel between Marie and Margery above all else: their predisposition to compulsive crying. Whilst Margery's tears are deeply irritating to those around her, Marie's outbursts are widely accepted as legitimate, albeit intense, episodes of devotional expression. Indeed, in the Alphabetum narrationum, the entire entry for 'tears' ('lacrima') is devoted to Marie of Oignies and her morally upright lachrymosity. ${ }^{109}$ In the fifteenth century, Arnold's work was translated into English as An Alphabet of Tales, and achieved even wider dissemination. ${ }^{110}$ Association with Marie's pious crying legitimizes Margery's tears, showing a worthy precedent for the phenomenon. The affirmative response of those around the tearful Marie is evoked to offer a model of acceptance - and respect - for Margery's weeping.

Kempe introduces the parallel between Margery and Marie as follows:

\begin{abstract}
And yet our Lord drew [the scribe] back in a short time - blessed may he be - so that he loved [Margery] more, and trusted more in her weeping and her crying than he ever did before. For afterwards he read of a woman called Mary of Oignies, [...] and of the plenteous tears that she wept, which made her feel so feeble and so weak that she might not endure to behold the cross, nor hear our Lord's Passion rehearsed, so she was resolved into tears of pity and compassion. ${ }^{111}$
\end{abstract}

Marie's example, summed up faithfully here, is clearly filtered by her vita. We read of how the scribe read Marie's vita to come to greater understanding of the pious nature of Margery's crying. A formerly good friar is assailing Margery from the pulpit, and turning much of the community against her. The scribe too is swayed, until God intervenes and inspires him to read Marie's vita. Now, he loves Margery more than ever and interprets her

108 Larrington; Yoshikawa, 'Mysticism'.

109 Ex. 435-36, pp. 246-47.

110 For the exempla featuring Marie, see: Banks (ed.), II, ex. 427, p. 293; ex. 429, p. 294.

111 MKBEng, 1.62.191-92. 'And yet owr Lord drow [the scribe] agen in short time, blissed mote he ben, that he lovyd [Margery] mor and trustyd mor to hir wepyng and hir crying than evyr he dede beforn, for aftyrward he red of a woman clepyd Maria de Oegines, [...] and of the plentyuows teerys that sche wept, the whech made hir so febyl and so weke that sche myth not endur to beheldyn the crosse, ne heryn owr Lordys Passyon rehersyd, so sche was resolvyd into terys of pyté and compassyon.' $M K B, 1.62 \cdot 3610-15.149$. 
tears as signs of unimpeachable piety. Depicting the shift from negative to positive interpretation of Margery's sobbing occurring in someone so close to the woman herself, surely highly invested in her tale, allows for an audience's initial unfavourable reaction to the woman. Such a reaction, with the right education, can be changed.

Kempe, then, implicitly proffers the model of the cleric-scribe's conversion for the various individuals who are swayed by clerical invective against Margery, and for those who just can't stand her tears - basically everyone. Even clerics can change their mind about the holy woman, if they recontextualize her tears in light of the proper sources. For example, sometime after Kempe's references to Marie of Oignies, a Dominican doctor Maistyr Custawns (presumably Thomas Constance) recapitulates the narrative of Marie's devotion condensed by Kempe when talking to Margery herself. ${ }^{112}$ The doctor's exposure to Marie's vita has sculpted his comprehension of Margery's pesky crying jags, of which he now approves. The scribe's earlier positive re-interpretation of Margery's tears is given more weight, as it is a replicable conversion. He is not 'reading too much' into Marie of Oignies' biography; it really does support Margery's own piety.

After his exposure to Marie's vita, Master Constance also seeks to spread a positive, or at least less hostile, reaction to Margery. The doctor asks another preacher to bear with Margery's crying fits in church, which he is shown to allow himself. Constance's anonymous colleague is persuaded to view Margery's tears more positively. He now tolerates her tearful outbursts during his sermon in church, and even promises the holy woman a warm welcome if she ever visits Norwich. The anonymous doctor's experience offers an example of mediated contact with Marie of Oignies' vita which broadly mirrors the situation faced by the reader of Margery's Book. He serves a useful extra-diegetic model for a potentially doubting audience. Nevertheless, the reader is encouraged to seek out the vita for themselves in a marginal annotation from the early sixteenth century on the only extant manuscript of the work. ${ }^{113}$ The Book notes that the scribe 'read of' ('red of') Marie of Oignies, but does not provide a source. ${ }^{114}$ However, the commentator appends a bibliographical clarification: 'Maria de oegines [/] liber'. ${ }^{\prime 15}$ The reader is invited to seek out Marie's vita, and thereby undergo the shift in attitude modelled by the scribe and Constance.

$112 M K B, 1.68 .3925-50.160-61$.

113 London, BL, MS Add. 61823.

114 MKBEng, 1.62.191, MKB, 1.62.3610.149.

115 Staley, 'Introduction', p. 5. 
The scope for manipulating reactions to Margery based on Marie's example is fairly bleak, however. Near the end of the chapter in which the scribe reads Marie's vita and comes to believe in the piety of Margery's weeping, the text relays that many others embrace Margery as a spiritual woman. Yet, this affirmative conversion is not brought about by reference to the exemplary Marie. Instead, time to get used to Margery and her weirdness softens the initial harsh responses to her and her particular brand of religiosity, at least in some quarters ('be processe of tyme'). ${ }^{116}$ Provision of a positive model for Margery's tears is simply not enough to convince a large swathe of Margery's community that she is pious. Countless detractors, including the antagonistic friar, continue to slander her.

Henry Jenkins writes extensively about fans as 'active producers and manipulators of meanings' from the texts and objects that they venerate. ${ }^{117}$ In Jenkins' words, fans are 'textual poachers', engaged readers 'who appropriate popular texts and reread them' - and re-write them - to serve their own interests. In various online communities, writer-fans populate their own stories with the imagined exploits of characters from their favourite narrative universes, re-working storylines to suit their needs. ${ }^{118}$ In 'slash fiction', for example, writers forge new sexual liaisons between characters, most often between two men not identified as gay in the source work. ${ }^{119}$ The form of interventionist practice which characterizes fanfiction is mirrored in Kempe's treatment of Marie of Oignies. ${ }^{120}$ After offering the generally faithful - if very brief - overview of Marie's spirituality discussed above, Kempe subtly re-writes an episode from Marie's life to make it provide a closer parallel to one of Margery's own tear-stained experiences.

In a nutshell, according to Kempe: Marie is ordered out of church by a priest troubled by her continual weeping, which she is unable to curtail. ${ }^{121}$ God visits the priest, infusing him with grace upon reading the Holy Gospel so that he weeps so copiously he drenches his robes and the altar. The priest cannot stop the tears of his own volition, and gains understanding of Marie's sobs as an uncontrollable mode of spiritual expression. However, Kempe's

116 MKB, 1.62.3646.150.

117 Textual Poaching, p. 23. See in particular: ibid., pp. 24-49, pp. 152-222; Convergence, pp. 175216; 'Star Trek'.

118 See, for example, the case study of Harry Potter fanfiction in: A. K. Allen.

119 On slash fiction, see in particular: Green, Jenkins, and Jenkins; Jenkins, Textual Poaching, pp. 185-222.

120 Perk discusses Kempe's book as fanfiction, though does not refer to Marie of Oignies.

$121 M K B, 1.62 .3621-25.149$. 
version of the scene omits a telling detail. In both the Middle English and Latin versions of Marie's vita, Marie petitions Christ directly to grant the derisive priest tears ('gate graunt of oure Lord with terys'; 'impetravitque à Domino cum lacrymis'). ${ }^{122}$ This request has been suppressed in Kempe's retelling. The Book's adaptation also states that Marie leaves the church due to the priest's demand ('at the request of a preyste'), caterwauling about her inability to hold back her tears. ${ }^{123}$ In the source materials, the priest only asks Marie to cease crying and pray quietly ('bade that she shulde praye softely and latte be hir weyping'; 'ut oraret cum silentio, \& lacrymas cohiberet'). ${ }^{124}$ It is Marie's inability to hold back her tears and intense humility that drives her from the church of her own accord.

The discrepancy between the texts results from the exigent circumstances in Margery's life that prompted Kempe's reference to Marie of Oignies to begin with. The friar who rails against Margery, described in the Book's preceding chapter, is particularly bothered by her presence in church. Margery keens and writhes during his sermons, thereby disturbing the congregation. The friar's distaste for her shenanigans results in her banning from the church whenever he preaches. Rewriting Marie's text to fit the circumstances of Margery's life functions as a form of wish-fulfilling fanfiction. In the imagined version of events, Margery is not banned from the friar's church, but instead he is gloriously converted. By affirming that this happened in the life of Marie, Margery's parallel, Kempe suggests that this may yet happen for Margery too. With a little textual Photoshopping, the 'star image' can depict anything the fan desires.

\section{Keeping Up With Kempe}

Kim Kardashian West's 'ugly crying face' is a viral online sensation. ${ }^{125}$ In 2008, Kourtney Kardashian, Kim's sister, drew attention to Kim's unfortunate mien when upset. In a 'confessional' from Keeping Up With the Kardashians (KUWtK), the family's massively popular reality-TV show, Kourtney declared: 'I start laughing at Kim when she's crying because I just

\footnotetext{
122 VMOME, 1.5.152-53.93; VMO, 1.1.17.640.

$123 M K B, 1.62 .3618-21.149$.

$124 V M O M E$, 1.5.148-49.93; VMO, 1.1.17.640.

125 Although still known as 'Kim Kardashian' by many, the star rebranded herself across all media outlets in 2014 as 'Kardashian West' following her marriage to rapper Kanye West. As such, I refer to her as 'Kardashian West' throughout. On celebrity and 'ugly crying', see: Cote.
} 
can't help it, she has this ugly crying face that she makes'. ${ }^{126}$ This footage, coupled with Kim's regular emotional outbursts, has become a well-known and much-circulated meme online. Margery is the Ur-example of 'ugly crying', and her Book is the fifteenth-century equivalent of must-see carcrash reality TV. Almost everyone finds Margery's crying obnoxious. ${ }^{127}$ Even the woman's closest relations cannot stand her incessant wails. During one of Margery's whine-athons in Canterbury, her husband pretends not to know her, and runs off. ${ }^{128} \mathrm{He}$ abandons Margery to the clutches of an angry mob that has formed around the urgent social issue of putting a stop to Margery's interminable wailing - or as the Book tells it, her suspected Lollardy.

In Sharon L. Jansen's summation, Margery is 'garrulous, attentionseeking, and funny, both repellent and endearing. ${ }^{129}$ The same can be said of Kardashian West. And for both women, 'ugly crying' operates as a metonym for the variety of ways in which they are 'always making a spectacle' of themselves. ${ }^{130}$ Indeed, in direct response to Margery's crying jag in Canterbury, an elderly monk informs her bluntly: "I wish that you were enclosed in a house of stone, so that no-one should speak with you." ${ }^{\prime 131}$ Margery's tears are a means of affectively 'taking up space', a sinful colonization of the public realm by a woman. Similar condemnation is evident in many of the comments appended to a YouTube video, Kim Kardashian's Best Ugly Crying Moments, which has netted over a million views as of April 2017:

she is such a disgrace for women.. shame on her.. so pathetic

Shes a massive DRAMA QUEEN AND SHE NEEDS TO GET OVER IT STUPID WOMAN

I can't believe I live in a world where this woman exists... God damnit[.] $]^{132}$

126 'Kardashian Family Vacation' (So2E08, first aired 4 May 2008). On the links between realityTV tears and medieval crying as confessional expressions of contrition, see: Weisl.

127 See, for example: $M K B, 1.13 .620-23.40$.

128 Ibid., 1.13.623-73.41-42.

129 N.p.

130 Ibid.

131 MKBEng, 1.13.63. "'I wold thow wer closyd in an hows of ston that ther schuld no man speke wyth the." $M K B$, 1.13.629-30.41.

132 Comments by YouTube users 'stiLLa himself', 'MUSIC IS MA L!FE!', and 'Frank Conrad' respectively. As of 8 April 2017 (11pm), the video had been viewed 1,078,567 times. 
Other commenters seize upon Kardashian West's illegitimacy as a 'worthy' celebrity. She is categorised as an 'attention whore', a fame-hungry 'train wreck' that should simply not be famous. ${ }^{133}$ Margery Kempe is trolled similarly in online comments from modern readers outside the academy. ${ }^{134}$ Kardashian West and Margery's stardom is in question because it emanates from a process of auto-celebrification. They are 'reality-TV famous' rather than the products of the traditional celebrity manufacturing process.

Reality-stars are famous because they have been on reality TV, not for any special talent. Initially, reality-TV producers operate as 'star-makers', choosing which lucky hopeful is cast in their shows and making tactical editorial decisions to present desired storylines. Their source material, however, is the brute force of persona, an individual who has consciously chosen to put themselves up as a 'star image' for audience consumption. Reality-stars typically engage in conscious attempts at auto-celebritization beyond the show which first brought them to public attention. They package and manage themselves as star-objects by appearances in other texts over which they have more control. Presence on social media, in celebrity magazines, and in the tabloid press are mainstays in the reality-star's toolkit. The reality-TV star harnesses the praxes of celebrification established in the traditional system, but under their own steam. 'Fake it till you make it' goes the saying, and that is surely the mantra of the reality-TV celeb. By performing the gestures of 'legitimate' fame often enough, to enough onlookers, and with enough skill, the wannabe becomes famous too. In a similar manner, Margery requires models of other acclaimed holy women to legitimize her own forms of piety, both within the diegesis (Margery and her community) and extra-textually (as the author seeks acclaim for the text's protagonist).

The Book details Margery's determined attempts to garner spiritual fame by modelling herself on other holy women. She is a fame-hungry fan, a wannabe desperate to transform herself into a celebrity saint in her own right. Though Margery grinds out her days on the D-list, she looks fannishly to a roster of A-list female saintly stars, including Marie of Oignies, in whose image she fabricates herself, or tries to. ${ }^{135}$ Kempe relies on a patchwork of citation, borrowing from various spiritual texts to construct a viable read: ecclesiastically and socially acceptable - holy life for Margery. Like Margery, Kardashian West needed a guide in the celebrification process.

133 Quotes from comments by 'Frank Beltra' and 'John Roberts'.

134 Bale, p. 16.

135 On this, see in particular: Atkinson, 'Sanctity', pp. 226-33; Lewis; Staley, Fictions, pp. 171-200; Yoshikawa, Meditations, pp. 94-104. 
She credits socialite-cum-minor-celebrity Paris Hilton as a mentor: "I do think I learned a lot from Paris. I think that she has always been so gracious to the paparazzi, to her fans, and has taught me, you know, that there's no real need or reason to never not be." ${ }^{\prime 136}$ For a number of years, Hilton employed Kardashian West, a then non-famous childhood friend, as a personal assistant and stylist in her own C-list celebrity life. ${ }^{137}$ Kardashian West's earliest onscreen appearances are in episodes of The Simple Life, the reality-TV show that launched Hilton as a star. ${ }^{1{ }^{8}}$ Whilst the pair were friends, footage shows Hilton exploiting the power differential between them, effectively putting Kardashian West in her place. This entry-level position in The Simple Life was productive, however. It functioned as an internship in the twinned businesses of reality-TV and auto-celebrification.

Kardashian West's own reality-TV show, KUWtK, launched in 2007. It instantly elevated her celebrity, and transformed the whole family into a celebrity brand. As of 2017, KUWtK is still going strong in its thirteenth season, with various spin-off Kardashian-focussed shows and crossmarketed merchandise. ${ }^{139}$ Audiences worldwide can't seem to get enough of Kardashian West and her family. Hilton is irrelevant; Kardashian West is omni-present in the media landscape. In the Book, Christ implies that Margery will achieve a similar usurpation of her role-model, St. Birgitta. He speaks to the English woman "'just as [he] spoke"' ("rygth as [he] spak") to her mentor, suggesting an equivalence between the pair. ${ }^{140}$ However, he blesses Margery alone with certain visions, assuring her that the Swedish saint "'never saw [him] in this way"' ("say [him] nevyr in this wyse")..141 Nevertheless, Birgitta has nothing to fear from Margery: she does not attain anything like the Swedish saint's fame in her time.

Chris Rojek attests that '[c]elebrities offer powerful affirmations of belonging, recognition, and meaning in the midst of the lives of their audiences, lives that may otherwise be poignantly experienced as under-performing anti-climactic or sub-clinically depressing. ${ }^{142}$ Margery's pre-mystic life

136 Pomarico, n.p. See also: Kardashian, Kardashian, and Kardashian, Konfidential, p. 100.

137 Kardashian West insists that she was not, in fact, Hilton's stylist, but the socialite was a client of her eBay-selling and closet-organizing business: Kardashian West and Swisher, 'Interview'. 138 'Ro-Day-O vs. Ro-Dee-O' (So1E01, first aired 2 December 2003), 'The Nolan Family' (So4Eo1, first aired 4 June 2006), 'The Ghauri Family (So4E02, first aired 11 June 2006), 'Murrie Family' (So4Eo6, first aired 16 July 2009).

139 See, for example: Kourtney \& Kim Take Miami; Kourtney \& Kim Take New York.

140 MKBEng, 1.20.83; $M K B, 1.20 .1089 .58$.

141 MKBEng, 1.20.83; MKB, 1.20.1085-86.58.

142 Celebrity, p. 52. 
was certainly no bed of roses. Indeed, the Book opens with an account of Margery's first pregnancy, a devastating experience which leads to an eight-month mental breakdown. ${ }^{143}$ During this period, Margery is beset by demons and diabolical temptations. When all consider her a lost cause, a visitation from Christ - the most potent religious celebrity of all - finally jump-starts her recovery. God has not forsaken her; if Margery devotes herself to Him fully, then all will be well. But how can Margery accomplish this mission, practically speaking? The numerous acclaimed holy women found in the Book function as role-models. These saintly celebs - or the models of faith they embody - offer the much maligned Margery a roadmap to full integration in her society, and ultimately to the recognition of her own sanctity. Margery is an attention-seeking acolyte, a superfan, whose greatest desire is not to be like a saint, but become one herself.

Margery's breakdown is provoked by her inability to confess a significant long-concealed sin. ${ }^{144}$ Thinking she is on the brink of death post-partum, the woman calls for a confessor. The cleric, though, rushes to rebuke Margery, cutting her off mid-flow and thus silencing her. Her transgression remains unshriven, and she fears for her eternal damnation. Diana Jefferies and Debbie Horsfall contend that Margery's sin is not based in any specific act. ${ }^{145}$ Rather, after her traumatic pregnancy she comes to renewed awareness of the original sin that afflicts all humanity, and her status as a 'daughter of Eve'. In Genesis 3.16, God instructs Eve on the gendered burden of sin she bears: 'In sorrow shalt thou bring forth children, and thou shalt be under thy husband's power, and he shall have dominion over thee. ${ }^{146}$ Margery's labour pains are visceral reminders of her transition from virgin to wife, and all that entails: the loss of both her bodily autonomy and subjective agency. ${ }^{147}$ Recognition of these losses propels the holy woman into insanity. In order to move beyond this annihilating relegation to bodiliness and reclaim her sanity, Margery must produce an alternate self-image. She turns to saintly mentors who seem to have redeemed, at least partially, the sinful female body via their religious praxes.

Kim Kardashian West's auto-celebritization is also rooted in a reclamation of subjectivity in the aftermath of trauma. In February 2007, she faced

143 MKB, 1.1.130-87.21-23.

144 Ibid., 1.1.142-50.22. This episode is often interpreted as post-partum psychosis or mental illness within a modern framework. See in particular: Craun; Freeman, Bogarad, and Sholomskas; Jefferies and Horsfall, pp. 350-52; Torn.

145 P. 353 .

146 Douay-Rheims Bible.

147 McAvoy, pp. 36-37. 
public humiliation after the leak of a sex-tape, made with the singer Ray J a few years earlier, when the pair were a couple. At this point, Kardashian West was mostly unknown, of interest primarily for her party-going with Paris Hilton and brief romance with boyband star Nick Lachey in 2006. The sex-tape, then, was the primary 'star image' with which the public interpreted Kardashian West. It materialized her celebrity, or rather notoriety, as a sexual object: a body without a voice, and without a story. Hilton faced the same issue, with her own sex-tape leaking less than a month before the debut of The Simple Life. The tape was certainly a media sensation. However, Hilton used her reality-TV series to offer a counter-narrative, crafting herself as the archetype of the rich dumb blonde. Once more, Kardashian West followed, and refined, Hilton's example. Five months after the release of her sex-tape, $K U W t K$ hit the air. In the show, Kardashian West comes across as likeable and family-oriented, in diametric opposition to the spoiled and entitled brattiness embodied by Hilton. Crucially, $K U W t K$ allowed Kardashian West to exercise control over the narrative circulating in the sex-tape. The woman having sex in the video is not just a body. She is a woman with a real life, with a real family, and with real emotions. Kempe's portrayal of Margery hits the same notes: she is not just body, but soul too.

In 2015, Kardashian West published the best-selling Selfish, a 448-page monograph composed of selfies taken in the period from 2006 to 2014 . The title of the work is telling. The word 'selfie' typically auto-corrects to 'selfish' when typed on a smartphone or similar device. And 'selfish' is a rather more polite version of the kind of epithets routinely hurled at Kardashian West due to the way she consistently puts herself in the spotlight, oftentimes through the medium of selfies. By naming her book Selfish, then, Kardashian West acknowledges, at least implicitly, this context to her fame. So doing, she neutralizes the barb's sting. She works with the 'auto-corrected' attitude that equates her stardom with vapidity and vanity, in order to offer a counter-narrative in the book itself. Selfish encourages you to consider Kardashian West with empathy, as a woman with a real life, made up of a series of 'self-ies', i.e. different facets of one's persona that shift according to a given context and for which we shape our appearance. This underscores the fragmented, performative aspect of all social activity, as we shape-shift like chameleons into our various roles: mother, wife, business woman, celebrity.

A series of nude and semi-nude photographs feature in Selfish. These risqué images first came to public attention in August 2014, when they were leaked online in the so-called 'iCloud hack', along with similar images of 
other female celebrities. ${ }^{148}$ Kardashian West comments that she had not considered including the nude selfies in Selfish until she saw them posted online after the hack. ${ }^{149}$ She dismisses any potential stigma attached to the photographs, laconically remarking that she is not 'mad at [the hackers]. lol'. By including the nude selfies in Selfish, Kardashian West re-inserts them into the fabric of her life. So doing, she re-asserts her subjective agency: the person in the non-consensually shared photographs is not just an object for sexual titillation, but a real person with a real life. What's more, Kardashian West has effectively de-sensationalized her non-consensual nudity, by freely posting nude or semi-nude pictures on her social media channels. In a 2016 interview, she reports that she is 'baffled' by the public's continued shocked (and admiring) response to nude photographs. ${ }^{150}$ After all: 'They've seen me naked 5oo times!' The stolen images are less titillating, and thus stimulate less spectatorial interest as they are not secret or hidden artefacts. It turns out that the thieves didn't really steal anything so personal after all; Kardashian West would have shared, if only they had asked.

As with Margery's Book, Selfish makes visible the celebrity manufacturing process. Megan Garber notes that in reading the book, 'you see the work that goes into making Kim Kardashian, the person, into Kim Kardashian, the icon. ${ }^{151}$ Countless selfies capture Kardashian West mid-beautification: in the make-up artist's chair, or with her hair in rollers. She reveals the dissonance between celebrity 'reality' and her normal existence. Kardashian West might walk the Oscars red-carpet as a paragon of glamour, but when she returns home, the gown comes off and comfy sweats rule..$^{15^{2}}$ Readers witness their icon testing photographic filters, and the myriad photographs she takes in order to produce that one 'perfect' selfie, or secure that iconic magazine shoot. ${ }^{153}$ The painstaking effort of maintaining a feminine persona, celebrity or otherwise, is revealed. All that labour pays off, though. In 2014, Kardashian West was the second most Googled person worldwide. ${ }^{154}$ In 2015, she was the most Googled person in twenty-six countries. ${ }^{55}$ With the hotly contested 2016 election cycle in the USA, she ceded the top spot in global searches to Donald Trump. A consolation prize: she earnt the crown for the year's most

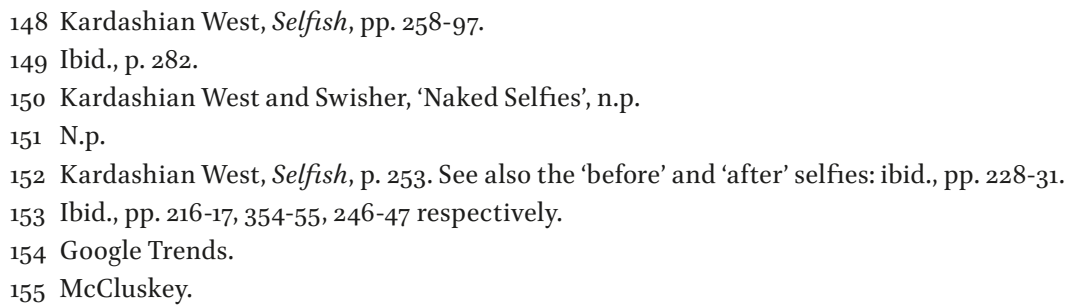


Googled selfie in the USA. ${ }^{15^{6}}$ The transformation is complete: Kardashian West is a wannabe no more. Why does she succeed, whilst Margery fails?

Christ intimates to Margery four times that she will be the object of a posthumous cult in the Book. These promises are ultimately empty. There is no evidence of a cult in Margery's memory. Regardless of Marie's example, Margery's tears could not be assimilated into a successful saintly identity, in the Catholic context at least. The Church of England commemorates Margery in its Calendar of saints on the 9 November, in a relatively recent addition to their liturgy. ${ }^{157}$ Margery's inclusion here, though, is almost a back-handed compliment. A 'commemoration' is the lowest form of veneration available for inclusion in the Calendar: a kind of 'participation trophy' for the holy woman who - bless her heart - tried so hard, but didn't actually produce the goods. In 2009, the General Convention of the Episcopal Church in the USA also provisionally approved the liturgical commemoration of Richard Rolle (d. 1349), Walter Hilton (d. 1396), and Margery Kempe on 28 September ${ }^{15^{8}}$ Even here, Margery finishes last. She is quite literally the hanger-on after the two illustrious male mystics in all official written material about the commemorative day circulated by the Church.

Instead of any significant medieval renown, evidence of a sizeable fan-base for Margery is instead found in modern academic scholarship, particularly in feminist critique from the 1980 os onwards. ${ }^{159}$ In 1998, Margery earnt an entry into the connotatively titled Who's Who in Christianity anthology, a veritable star-chart of religious celebs. The last line of Margery's entry concisely captures the shift in the holy woman's fortunes: 'In recent years she has become something of a feminist heroine. ${ }^{160}$ Margery's Book is so compelling because our wailing heroine fails at - or more charitably 'struggles with' - her objective of securing sanctity. In a personal blogpost, Clarissa W. Atkinson reflects on Margery's impact in her professional life as a medievalist. ${ }^{161}$ Atkinson was on the vanguard of academic feminism, undertaking postgraduate study at a time when women were practically absent from the medievalist canon. With Margery, she finally found 'a recognizable (and annoying) human being'. Academic interest in Margery is founded on Margery's relatability: she is a woman scrambling to find

\footnotetext{
156 Johnson and McCluskey; Lang.

157 Brother Tristram and Kershaw (eds.), p. 502.

158 Church Pension Fund, p. 611.

159 On this, see in particular: Tolhurst.

16o Cohn-Sherbok (ed.), p. 167.

161 '40 Years', n.p.
} 
her place in a male-dominated world, balancing the competing demands of family, community, and personal passions.

Margery is not (academically) famous because she is (or was) recognised as a saint, a perfected image of (holy) womanhood. Rather, she is a celebrity, at least in medievalist circles, for the messiness of her persistent bids for (holy) fame. Margery has become famous for wanting to be famous. Jeffrey Sconce affirms that Paris Hilton's 'reality TV-level' fame depends on her consistent (and perhaps even knowing) failure at doing something truly celebrity-worthy: her entire persona depends on her signature inability to do or contribute anything productive, making her fame the most pure and tasteful of all. ${ }^{162}$ Similarly, Margery's incapacity to perform holiness 'productively' underpins her enduring presence in the academic media-scape. The mystic's failure, however, exposes the reality of the hagiographic star-system, the constructedness of accepted saintly identities. Katherine J. Lewis suggests that the Book was 'intended to plug a perceived gap in female English sanctity by providing a saint who was Katherine, Bridget, Mary Magdalene and others all rolled into one - thus providing something for everyone. ${ }^{163}$ Margery (or Kempe's) suturing together of numerous female saintly identities is a conscious hagiographical move to create a female English 'multi-saint'. In other words, she is a try-hard, and trying too hard too obviously is the antithesis of celebrity cool. Margery's behaviours may not be 'tasteful', to quote Sconce, but they demonstrate in perhaps the 'purest' form the ways in which saints are artificial objects, cobbled together from various narratives and for various ideological motives. ${ }^{164}$ As a 'wannabe', then, Margery shows us how the 'real' stars are made.

The genius of Kardashian West, and to a much more limited extent Simpson, is that she reveals the inequity and artificiality of the celebrification process, and leverages this revelation to support her celebrity trajectory. Kardashian West and Simpson are the hyperreal of womanhood. They exist as mediatized images which reveal the logical end-point of the patriarchally enforced pressure that society places on all women to look and act in certain ways. Simpson's confessional reality-TV show, Price of Beauty, lifts the lid on beauty standards worldwide, but equally throws off refracted light to reveal the extreme measures Simpson must routinely take to be on TV, to be a woman in Hollywood and the chart-topping music biz. Kardashian West turns to social media and selfies to chronicle her own navigation of the socio-cultural demands placed on female appearance and comportment. 
That she may enjoy dressing up or being photographed is not important here, no matter how the tabloids might frame it. What matters is that she consciously shows you the 'before' and 'after', how celebrity is manufactured. More crucially, this revelation emphasizes the constructed-ness of the image of socially 'legitimate' cis-heterosexual Western womanhood itself. Even before she snapped her first selfie, or appeared on any TV, Kardashian West was always already imprisoned in this panoptical woman-ification system, as are all women who must conform - or pay the price - to what society, at a given moment, designates as the appearance and behaviour of 'real' and 'legitimate' (read: acceptable) womanhood. She has managed to extract value from this system, to play it at its own game: she mediatizes herself, and so doing holds up a mirror - or smartphone - to the cameras of patriarchy which adorn the walls of the panopticon in which all women find ourselves.

Wendy Harding affirms that the Book stages 'an unequal struggle for control of channels of communication'. ${ }^{165}$ The illiterate Margery is dependent on oral expression to render her life into narrative. ${ }^{166}$ In order to preserve her life story, Margery must give her spoken words, and thus her narrative agency, to an individual who can process her oral account into text: the cleric Kempe. The mystic 'cannot write her own script' ${ }^{167}$ Writing permits the elision of Margery's body (subjectivity), as text conveys meaning 'without the necessity of bodily contact'. ${ }^{168}$ Moreover, in the epistemological hierarchy of the late Middle Ages, textuality is the most authoritative communicative format. Margery's vocalizations are simply less significant than Kempe's interpretation of them, and can never be fully represented in text in any case. The holy woman depends entirely on her textual producer to purvey her 'star image'. In comparison, Kim Kardashian West is in almost complete control of her own celebrity narrative. Reality-TV producers might have first brought her into the public eye, but they no longer run the show. Paris Hilton's ever-waning fame may, to return to Sconce's critique, rest upon her 'signature inability to do or contribute any thing productive'. ${ }^{69}$ Kardashian West, by contrast, is a digital entrepreneur, whose celebrity springs directly from her industrious and innovative media interventions.

165 P. 170.

166 Ibid., p. 174 .

167 Bynum, Fragmentation, p. 41.

168 Harding, p. 172.

169 P. 336. 
Kardashian West has harnessed the power of social media to disrupt the traditional model of 'top-down' celebrity production, in which the starobject is controlled by her producer-creator. ${ }^{170}$ She assiduously manages her multiple social media profiles. As of April 2017, the star has over 177 million followers across her Twitter, Instagram, and Facebook accounts. ${ }^{171}$ These social media channels equate to multimedia networks which are completely under Kardashian West's control. In posts shared directly with her followers, Kardashian West carefully sculpts the particular image of celebrity she wishes to portray. She frequently anticipates content in her reality-TV show, releasing news on her social media channels to control the story, and uses her multiple platforms to refute celebrity gossip. In her analyses of Margery's orality, Harding explains that oral communication 'is not linear but interactive and global', a means of mediation that nevertheless depends on 'the body in its entirety. ${ }^{172}$ These characteristics similarly govern social media. Indeed, social media is useful to Kardashian West for precisely these reasons. It allows her to interact with fans across the globe in an informal manner. Moreover, the star's social media accounts allow her to foreground her subjectivity as an unavoidable part of the Kim-Kardashian-West package. She resists the reduction of her existence to body alone as a female celebrity and sex symbol. Instead, she shows followers her 'body in its entirety', complete with her personality, mind, and affect. This representation also serves to heighten the sense for fans that she is authentic above all, and thus supports her broader celebrity identity as a 'real' star.

Kardashian West subverts the textual and media hierarchy of traditional celebrity. The 'original' work of her fame, $K U W t K$, may be authentic, but only shows a partial view of her life. In order to get the really good stuff, the fans have to go direct to the source: Kim herself. 'Derivative' celebrity-texts, including her social media posts, thus usurp the authority of the 'original' works. For example, the autobiographical exposé Kardashian Konfidential, co-authored with her sisters Kourtney and Khloé, allows Kim to share 'the real scoop' about her life. ${ }^{173}$ Whilst fans might 'know a lot about' the clan from watching $K U W t K$, they 'don't know everything... yet!' Kardashian West thus acknowledges, and feeds, fans' hunger to consume ever more pieces of her life - but

170 Ingram; Kardashian West and Swisher, 'Interview', 'Naked Selfies'; Kirst.

171 As of 9 April 2017, Kardashian West had 50.8 million followers on Twitter; 97.4 million followers on Instagram; and 28.9 followers on Facebook.

172 P. 172.

173 Front dust jacket copy. For an explicit example of the book offering 'more', see: ibid., pp. 6768. See also the sisters' novel, Dollhouse, which is a transparent restaging of the Kardashian-fame narrative. 
only on her own (textual) terms and for her own gain. She is a consummate businesswoman, extraordinarily savvy in the art of auto-celebrification. ${ }^{174}$

Kardashian West's auto-celebrification strategies - in particular her policy of radical self-disclosure on social media - are not without danger, however. In October 2016, she was a victim of a robbery in her Paris hotel. Armed thieves broke into her hotel room, tied her up, and made off with approximately ten million dollars' worth of jewellery. Kardashian West believes, as do many commentators, that the thieves tracked her activities in Paris through her extensive posts to social media, as she documented her time at Paris Fashion Week. ${ }^{175}$ A sexy selfie posted on Instagram a few days before the robbery showcased a newly acquired four-million-dollar diamond ring, stolen by the thieves. ${ }^{176}$ She Snapchatted early in the evening of the day of the robbery that she was alone in her hotel suite, as her bodyguard had gone out with her sister. There is a price to using social media as a tool of selfcelebrification: a loss of privacy, and concomitant loss of personal security.

After the robbery, Kardashian West took a three-month hiatus from all social media, returning to her multiple platforms only in January 2017. Beyond offering police her testimony, she kept silent on her experiences, saving her account instead for a special episode of $K U W t K{ }^{177}$ The 'big reveal' of Kardashian West's first-person account of the robbery displayed all the hallmarks of her digital entrepeneurship. The robbery may have forced her social-media accounts to go dark for three months, but in this episode she returned fully to our screens with a bang. The KUWtK episode functionally 'scooped' other broadcast media in terms of featuring Kardashian West's first-person account of her traumatizing ordeal. Moreover, in a series of tweets shortly before the episode first aired, Kardashian West teased the show's authentically raw emotional content. The episode was 'going to be very tough' for her. ${ }^{178}$ Nevertheless, it was 'important' to release the content, 'to share this story through [her] eyes \& not in an interview where my own words could be twisted. ${ }^{179}$ This emphasizes the fact that other narratives circulating around the Parisian incident are not (fully) authentic. The show, then, sets the record

174 On celebrity as a business, see Kardashian, Kardashian, and Kardashian, Konfidential, pp. 131-39, 213-19.

175 On the robbery, see in particular: Aurthur; Corinthios et al; Quinn; Seal. Kardashian West speculates on being followed on social media in an episode of $K U W t K$ : 'Paris' (S13Eo2, first aired 19 March 2017).

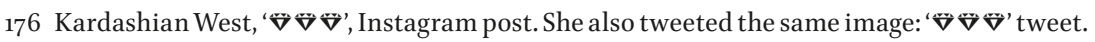

177 'Paris' (S13E02, first aired 19 March 2017).

178 Kardashian West, 'Tonight's episode'; cited in Aurthur, n.p.

179 Kardashian West, 'I thought it was important'; cited in Aurthur, n.p. 
straight. What's more, the tweet implies that fans should not necessarily trust any Kardashian-West content not produced by the woman herself.

Graphic re-assertion of the traumatic dimension of the robbery is particularly important given the instantaneous backlash to the theft that the star faced. As soon as news broke online, cruel memes and conspiracy theories began to surface. ${ }^{180}$ The robbery was just a 'publicity stunt' by a talentless woman who would do anything for a ratings boost. She 'brought it on herself' after flaunting her wealth on social media and TV for so long. As Alex Abad-Santos remarks: '[d] espite Kardashian living her life almost entirely in the open, many people still don't see her as a person. To her biggest critics, there's no separation between the woman and her brand. And that allows us to forget our own humanity while calling hers into question. ${ }^{181}$ Indeed, during the robbery itself, Kardashian West pled for her life by urging the thieves to see her as a 'real' person, not a celebrity brand: “'Don't kill me, I have babies, don't kill me, please, I have babies! I'm a mom! Take whatever you want!" 182 In the fight-back against the accusations of the robbery being a hoax, Kardashian West's supporters similarly emphasized the star's humanity, in terms of her motherhood and family relationships. ${ }^{183}$ The implicit message, however well-intentioned these remarks were: Kardashian West deserves to live because she fulfils the necessary conditions levied by the patriarchy, because she is a mother and a wife and a social (read also appropriately socialized) being. No mention is made, for instance, of the presumably scores of people dependent on Kardashian West for their livelihood: paparazzi, designers, make-up artists, her entourage. Kardashian West's impressive generative capacity as a breadwinner - and likely source of many other families' daily bread - is elided. It screams of too much agency, after all. Instead, she is cast as worthy of humanity as, and seemingly only as, a wife and a mother. These elements rubber-stamp her - and by extension all woman - with the designation of 'human'. If one falls short of these oppressive ideals? Death is no longer a tragedy but the very definition of just desserts. The battle for Kardashian West's humanity, then, demonstrates the excruciating situation women face under patriarchy more generally: not accepted as fully human until and unless we are defined in relation to our men, our child-bearing capacity, and our family of origin.

180 For examples and analyses, see in particular: Abad-Santos; Charlton; Davison; Givhan.

181 N.p.

182 As reported by the hotel concierge, identified only as 'Abdulrahman', in Seal, n.p.

183 Davison, n.p. 
The backlash to the Paris robbery demonstrates the way in which Kardashian West's detractors perceive her as too commodified to be a 'real' woman, whatever that actually means. Above all, Kim Kardashian West's brand is dependent on her individual agency, her forward-thinking smarts and her ceaseless hustle. As a brand, then, she is a vision of the unpalatably self-actualized womanhood that the patriarchy seeks to contain. Despite supporters' claims to her humanity, she is not viewed as a human subject, but instead a celebrity-brand, and thus unworthy of empathy and basic respect. This might suggest, then, that Kardashian West's celebrity-brand is broadly confirmed, and thus offers her significant protection. This is not the case. The vast majority of people accept her status as a brand, a pre-packaged commodity that sells an abundance of stuff to the public. Her celebrity, essentially her recognition in the public eye, functionally underpins her viability as a brand. Yet it is this celebrity which is hotly contested. The denial of Kardashian West's 'specialness' - any genuine talent from which her celebrity is, or should be, derived - is a central plank of criticisms levelled against her.

Kardashian West's stardom is not viewed as fully 'legitimate' by many. In June 2015, her appearance on the National Public Radio (NPR) show, 'Wait Wait... Don't Tell Me!' provoked ire in listeners. ${ }^{184}$ Hundreds wrote in to complain, with many threatening to cease their NPR sponsorship in response. ${ }^{185}$ A complaint from listener Brianna Frazier is indicative of the tenor of the backlash: 'vapid, talentless, and shallow individuals who have not earned fame or fortune through an ounce of hard work have no place on a show of such caliber'. Earlier in this chapter, I remarked that the symbiotic relationship of Jacques of Vitry and Marie of Oignies rests upon their complementary deficiencies. Jacques is 'much too human to be a saint', whilst Marie is 'too female' to be a cleric. ${ }^{186}$ Kardashian West is trapped in a parallel double-bind: she is 'too ordinary' ('too human') to be a legitimate celebrity, yet too commodified to be a 'real' human. Similarly, the 'femaleness' which prohibits Marie's clerical career operates as a commodity, or commodifying mechanism(s), which governs the holy woman's life and interactions. It is not a reflection of the genuine state of lived womanhood. Rather, it is a hollowed out and overly determined category, manufactured by the Catholic Church according to its doctrinal logic and by a medieval society which considered women to be inferior to

184 Pesca et al. This is a typical reaction to Kardashian West's appearance in 'serious' media. See, for example: Gannes.

185 E. Jensen, n.p.

186 McDonnell, Beguines, p. 3 . 
men in intellectual, emotional, and biological terms. Kardashian West has the relative luxury of being the agent of her own commodification. Marie of Oignies, on the other hand, has little recourse.

In religious terms, Kardashian West is a celebrity not via any official canonization, but instead via grass-roots lay devotion. Marie of Oignies's stardom is also a product of lay devotion. She was never officially canonized, only attaining the lower honour conferred by beatification. Nevertheless, she is recognized as legitimately holy because her mode of celebrification, Jacques' vita, conforms to the traditional routes of sanctification. Moreover, Jacques enacted Marie's 'local canonization' in 1226, granting an indulgence to any individual who venerated Marie's remains in a newly fabricated shrine in Oignies. ${ }^{187}$ Margery Kempe and Kim Kardashian West's autocelebritization, however, does not have 'official' backing, and is enacted via non-traditional routes which fundamentally threaten the establishment, be that the Church or broadcast media. As Margery is dismissed as heretical and annoying, Kim is classified as talentless and low-class. Despite her success, Kardashian West's auto-celebrification is only partially successful. A significant portion of the public resist her disruption of the celebrity machine. But, love her or hate her, they know who Kim Kardashian West is. 'Famous' or 'infamous', she remains in the spotlight. In much the same way, Margery Kempe is 'everywhere treated as a miracle, a scandal, a cause celèbre'. ${ }^{188}$ She endures as an object of fascination and irritation, both in her own contemporary context and in academic scholarship alike.

\section{Fans in the Academy}

Writing Marie of Oignies' vita, Jacques of Vitry forcibly fragments the holy woman, parcelling her life out into textual vignettes which come to signify the holy woman's entire existence. This is not an entirely deleterious process, however. Marie dwells not just in the Lord's embrace, but also in the manuscript(s) which preserve her biography and resonate as textual relics. Celebrification in the medieval context entails 'manuscript-ification'. Positing himself as Marie's superfan, Jacques writes himself into existence, both within the vita and beyond the text by significantly developing his ecclesiastical career. And yet, this is not enough for Jacques, it seems. He is only partially materialized in Marie's manuscripts; he wants to be fully absorbed, 
Figure 10 Parchment mitre commissioned by Jacques of Vitry (front)

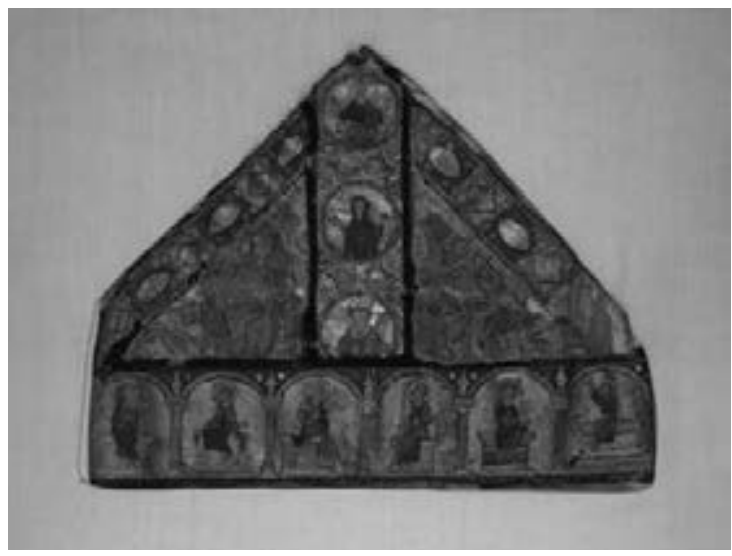

Unknown school (Italy or Palestine?). Produced 1216 or soon thereafter. Namur, TreM.a (Musée des Arts anciens du Namurois-Trésor d'Oignies). Deposit of the Fondation Roi Baudouin to the Société archéologique de Namur, inv. TO27. Digitized with the assistance of the Délégation générale à la numérisation des Patrimoines culturel - FWB

'manuscriptified' in his entirety. This desire is testified by a startling donation which Jacques made to the Oignies priory upon his death in 1240: an illustrated parchment mitre, a manuscript all of his own (see Figs. 10 and 11). ${ }^{189}$

Though mitres were routinely stiffened with parchment for structural stability, Jacques' is unique in its composition entirely of the material. There are no other parchment mitres of this kind in all known museum and ecclesiastical collections. ${ }^{190}$ The potential of the mitre's material support is fully exploited: it is covered in exquisite illustration. The pictorial cycle, in combination with their support, are biographical, recounting Jacques' episcopal trajectory and elevated spiritual status to the viewer/reader. On the front, the titulus (bisecting vertical bands) is marked with three medallions, filled with an image of a bishop, the Virgin Mary, and Christ. The organization of the medallions, with Christ at the top and the bishop at the bottom, reflects the spiritual rankings of the figures. The representation of the bishop is a proxy for its episcopal wearer, Jacques, and suggests his close proximity to God. The diagonal edges of the piece are richly covered with

189 On the mitre, see in particular: Courtoy, pp. 216-18; Folda, pp. 142-44. Jacques donated various other objects to the priory. For details, see: Courtoy, pp. 127-28, 198-225; Collet, pp. 14-15, 27-31, 34-36. 190 Courtoy, p. 216; Folda, p. 143. Cf Paper mitres in a very different context: Cohen, p. 407. In 1398, two disgraced Augustinian monks - denounced for idolatry, witchcraft, and apostasy - were crowned with paper mitres bearing their names on the procession to their execution. 
Figure 11 Parchment mitre commissioned by Jacques of Vitry (back)

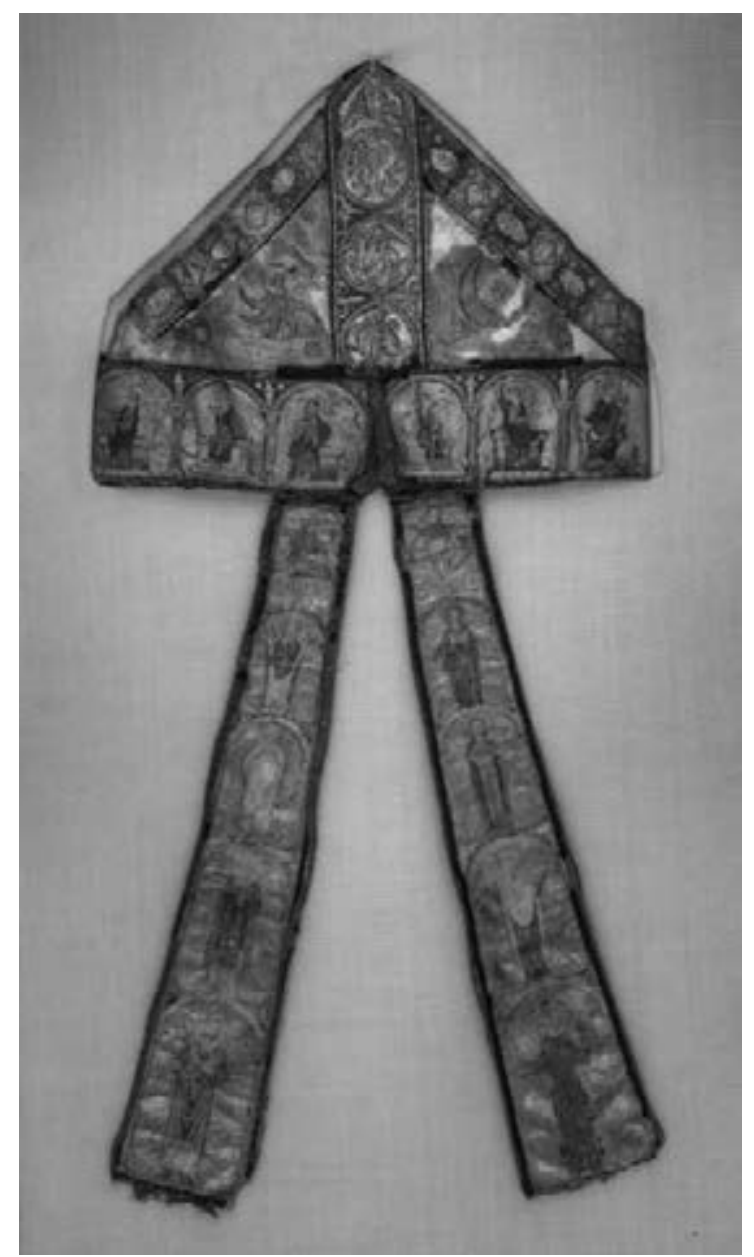

Unknown school (Italy or Palestine?). Produced 1216 or soon thereafter. Namur, TreM.a (Musée des Arts anciens du Namurois-Trésor d'Oignies). Deposit of the Fondation Roi Baudouin to the Société archéologique de Namur, inv. TO27. Digitized with the assistance of the Délégation générale à la numérisation des Patrimoines culturel - FWB

the simulation of precious stones in a variety of shapes. This ornamentation creates, as Jaroslav Folda notes, 'a sumptuous jewelled and golden episcopal object that would perhaps match, or at least reflect, the bishop's liturgical books'. ${ }^{191}$ Jacques symbolizes his immense liturgical comprehension by bedecking himself in a codicological veneer. 
The two bands hanging down from the back (infulae) contain decoration only on one face. Miniatures of ten male and female unidentified saints and worshippers decorate these strips. Whilst Jacques may not be able to be a saint himself, he carries numerous saints on his episcopal person, symbolically connected to and absorbing their piety. On one side of the infulae, the saints are imaged. The other side is left bare, unadorned parchment-skin that makes contact with Jacques' body each time he wears his mitre. This contact enacts a fusion of Jacques to the saints, through the very object which symbolizes most explicitly his own religious excellence. The bottom figures of each infula carry a palm and book, representing pilgrimage to Jerusalem. These miniatures form an 'iconographic programme', promoting the dynamic mission of its wearer as bishop of Acre. ${ }^{192}$ With this mitre, which for all intents and purposes is an elaborately illustrated manuscript, Jacques displays his yearning to become a series of textual images himself, a spiritual star like Marie. Doffing a parchment 'skin', he becomes a manuscript himself, a text to be read and revered through the ages. This echoes the phenomena I analysed in the conclusion to Chapter 2, the means by which human and manuscript interact, bleeding into one another as one.

Jacques' appreciation for text and manuscript as vehicles for genuine presence is not some peculiar phenomenon of days gone by. Rather, this is a prevailing undercurrent in fan culture, predicated more or less explicitly on a sense that the fan-object speaks to something 'real', of importance to fans. Moreover, fictional characters from favourite fan-objects routinely take on an aura of 'realness' in fan culture, even going on to develop a life of their own, whether in fan fiction or in the fan's imagination. Academic scholarship operates somewhat similarly. Indeed, Ghislaine McDayter asserts that 'there are few things more "material" (or more like a saint's relic) than a literary text in the academy. ${ }^{193}$ In our literary analyses, critics engage in an act of (re)materialization, piecing together the personality and form of those whose stories we purportedly study. In deeply engaging with the text - the immaterial literary elements of a holy woman's life - her 'flesh get[s] in the way', and we end up deeply engaging with the woman herself. ${ }^{194}$

All study of the past, as Nicholas Watson remarks, has 'emotional designs on its object' ${ }^{\prime}{ }^{195}$ Whatever the complexion of those emotions, they inevitably impact our methodological approaches and research findings. The

192 Ibid., p. 144.

193 P. 172.

194 Ibid., p. 173.

195 'Desire', p. 61. 
academic's 'self-legimitating and claimed identity' of 'critical rationality, objectivity, and neutrality' is ineluctably compromised. ${ }^{196}$ We might not self-identify as 'fans' of the objects of our scholarship, eschewing the label of 'acafan' (plural: 'acafen') ${ }^{197}$ Nevertheless, we engage in the creative intellectual practices that are the mainstay of fandom in almost every aspect of our scholarly work. 'Acafan' is not a derogatory label. Fans are, above all, 'acerbic critics' ('critiques acerbes') of the objects that capture their attention. ${ }^{198}$ With often surgical precision, they dissect texts to expose latent signification, and pry open textual fractures to uncover fresh interpretations. As Henry Jenkins explains, both academics and fans 'have a passion for thinking deeply and talking often about things they love. ${ }^{199}$ The output of such thinking and feeling, whether in the academy or in online fan communities, belongs to the 'fanon': 'the many stories, ideas, images, features, etc. that fans add or revise [to a given source text], usually outside of a commercial context. ${ }^{200}$ In this context, this book itself is explicitly fanonical.

Watson avers that Caroline Walker Bynum's Holy Feast and Holy Fast - one of the most influential works of feminist hagiographic scholarship to date - evinces a 'desire' for 'discursive union' with the medieval holy women who are the primary object of its scholarship. ${ }^{201}$ In this, Holy Feast situates itself 'in a common tradition' with those women's 'desire for union with God', albeit implicitly. Bynum herself becomes a mystic, and the monograph becomes a work of mystical historiography-cum-theology. ${ }^{202}$ In other words, Holy Feast is fanonical, and its author writes from a place of 'acafandom'. This does not undermine the quality of Bynum's work, nor the absolute importance of her scholarship for feminist hagiographical studies. Recognition of our status as 'acafen' permits us to interrogate how and why we create such intimate affective bonds with the past. It also

196 Hills, 'Media Academics', p. 35.

197 The term 'aca-fan' is a shorthand for 'academic fan' (otherwise known as the 'scholar-fan'). On 'aca-fen' and 'aca-fandom', see: Hills, Fan Culture, pp. xvii-xxxviii; 'Media Academics'; Jenkins, Fans, pp. 1, 12; Jenkins and TWC Editor, para. 2.1-2.7.

198 My translation; Jenkins, 'Panorama', para. 24. See also: Hills, 'Media Academics', p. 37.

199 Jenkins and TWC Editor, para. 2.7

200 A. K. Allen, p. 279-80.

201 'Desire', p. 73. He responds directly to Biddick's critique of Bynum's monograph, which argued that Bynum becomes problematically conflated with the medieval holy women she studies in Holy Feast: Biddick, pp. 135-62 (see in particular pp. 140-41, 16o-61). See also Watson's sequel to 'Desire': 'Phantasmal Past'.

202 Watson, 'Desire', p. 68-72; 'Phantasmal Past', p. 2. On studying scholars of mysticism as mystics themselves, see also: Kripal, Roads, in particular pp. 1-31. 
enables us to consider the moment in which we write in terms of its own historicity, namely what is at stake in our academic criticism, including the structures, biases, and concerns which most influence us. Read as a work of acafandom, Holy Feast's central organizational and ideological thrust comes more fully to light: an effort to 'redeem the past, with its institutions, beliefs, and stories, for feminists. ${ }^{203}$

Academics interact with holy women such as Marie of Oignies and Margery Kempe at perhaps the purest level of fandom. The relationship between scholar and text is totally parasocial. And yet, as we incessantly debate textual minutiae - in professional or personal settings, in writing or in lectures - we become intimate with our literary star-texts. Our fannish obsession constitutes a key plank in our professional identity as researchers. As the bread-and-butter of scholarship, it fuels our professional life. The text engenders the academic, in much the same way as celebrity implicitly demands a fan-base. The productive energy flows both ways. Scholarship is another form of celebrification. We splice together diverse textual elements to fabricate a single version of events, or a coherent interpretation of a holy woman's life story. Our scholarly attention suggests that a holy woman is worthy of study, that she has the makings of an academic celebrity.

In writing this chapter, I celebrify Marie of Oignies yet another time. This chapter originated as a section of my $\mathrm{PhD}$ thesis. In that draft, however, I avoided any discussion of Margery Kempe. Including Margery as part of Marie's celebrity formation is a calculated move. The Englishwoman is a big draw for academic audiences: she is a 'bankable' holy woman. In comparison, Marie of Oignies is a 'nobody': her vita is actually 'best known to scholars' for its inclusion in Margery's Book. ${ }^{204}$ Kempe utilized Marie of Oignies to legitimize Margery's piety. In a reciprocal move, I refer to Margery in order to leverage her acknowledged academic celebrity, and thereby establish Marie in similar terms. My motives in this are not entirely altruistic. In celebrifying Marie, I hope, more or less consciously, to share part of her spotlight. Recognition of Marie's stardom entails, implicitly, an appreciation for my intellectual skills. Such appreciation draws, tantalizingly, the possibility of a wider readership for my scholarly outputs, greater academic impact, and ultimately increased chance of career advancement. Jacques of Vitry and I make strange bedfellows indeed. 


\section{My Avatar, My Soul: When Mystics Log On}

\section{Vision, Presence, and Virtual Reality}

If there's one thing wannabe-saint Margery Kempe can do well, it's hobnob with biblical types. Margery makes it a priority to be seen at all the best spiritual parties. In one of her earliest visions, she inserts herself into the Nativity scene as a dutiful helpmate to the Virgin and her baby. ${ }^{1}$ She procures lodgings in Bethlehem, begs for food and cloth, and even swaddles the Christ Child. So doing, Margery takes on the role of the handmaid or midwife that assists at Christ's birth, an apocryphal figure that was nevertheless a main-stay of Nativity iconography. As with most elements in Margery's career as a holy woman, though, she's got some stiff competition in the child-care arena. In a vision, Ida of Louvain goes one further, and bathes the infant Christ. Drying him off, Ida plays with him 'familiarly in motherly fashion' ('materno more familiariter'). ${ }^{2}$ In fact, her maternal attachment is so strong that she refuses the Virgin Mary's request for her to hand back the child, leading to a farcical wrestling match between the pair.

Margery Kempe and Ida of Louvain do not contemplate biblical history with dry theological detachment. Rather, they immerse themselves in it fully, injecting themselves into the action. Their devotional proclivities reflect the growing popularity of dynamic visualization of biblical history as a form of prayer. Meditational manuals proliferated from the mid-twelfth century onwards. These works are essentially 'visionary scripts', 'texts meant to help readers visualize the life of Christ so vividly that pious imagination would shade into visionary experience'. ${ }^{3}$ For the skilled, 'visualizing becomes seeing.' ${ }^{4}$ The ultimate aim of seeing was to become fully present at the moment in which the event occurs. This is underscored by the fourteenthcentury pseudo-Bonaventuran Meditaciones vite Christi (Meditations on the Life of Christ), the most popular text of its kind. The author, somewhat dubiously identified as John of Caulibus, proclaims: 'Simply make yourself present in the very place where, before your eyes, it occurs to your mind that

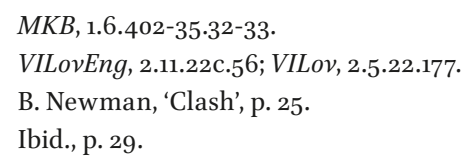


events were taking place. ${ }^{5}$ In this move, the visionary inserts themselves into biblical history as an active participant in a kind of divine 'virtual reality'. Writing in 2013, Jesuit priest Antonio Spadaro maintains that this kind of medieval 'virtual reality' meets the needs of modern Christians, thoroughly acculturated to the participatory and individualistic bent of much modern media culture. ${ }^{6}$ In an earlier article, published in a journal approved by the Vatican Secretary of State, the cleric called upon Catholics to enter the three-dimensional online environment of Second Life (SL). ${ }^{7}$ The virtual world represents a mission field, in which the pious should spread the Word.

It's 28 April 2016. I'm sat at home, in front of my laptop. On the screen in front of me, my digital representation (avatar) is in SL. Spadaro's contentions as to the draw of spiritual 'virtual reality', and SL as a space for religious ministry, ring in my ears. I'm attending a service at the First United Church of Christ and Conference Centre in Second Life (FUCCSL), along with a handful of other SL users. The minister's sermon consists of 'imaginative prayer. ${ }^{8}$ The pastor situates us as actors in a biblical scene: 'You've spent the night sleeping in the same room as Jesus and his disciples'. ${ }^{9}$ At the climax of the scene, Jesus speaks to us directly: “I'm glad you're here. [...] I was praying. Would you like to pray with me?"' He then teaches us the Lord's Prayer. It's an uncanny parallel of the immersive visualizations contained in medieval meditation manuals. SL is particularly suited to the technique, or so it feels. I'm already engaged in an act of visualization, projecting myself from offline body to online avatar. I don't just see my avatar, I am my avatar, authentically present in the 'real' digital realm. A further projection outwards, backwards into the biblical narrative, just adds another layer. It's as if my SL avatar 'logs on' to another virtual world, one that happens to be religiously themed.

Various individuals have commented on the religious valency of cyberspace. ${ }^{10}$ Julian Dibbell, a consultant to the creators of SL (Linden $\mathrm{Lab}$ ), argues that there are significant links between all online/virtual

5 Meditations, 108.332. 'te ibidem presente exhibendo, ac si in tua praescencia fierent prout simpliciter anime cogitanti occurit'. Meditaciones, 108.349-50; cited in B. Newman, 'Clash', p. 28 n. 83. On the Meditations, see also above, Introduction, p. 13, n. 9 .

6 Cybergrace, loc. 232-61.

7 'Desiderio', p. 278. This concords with Church guidance as to cyberspace as a space for evangelism: Pontifical Council for Social Communications, 'Ethics', IV.18.

8 Josh, n.p.

9 The exercise is adapted from: Oestreicher and Warner, pp. 85-87.

10 On cyberspace as sacred in its totality, see: Casey, 'Examination', pp. 197-201; Noble, pp. 1586o; Spadaro, Cybergrace, loc. 35-48; Cybertheology, pp. 10-11; Wertheim, pp. 15-21, pp. 38-40, pp. $253-66$ 
and (religious) offline experiences. He maintains that the experience of virtual reality involves the same processes of making meaning from signs and symbols as religious experience: 'You see signs and signals but you give them meaning. Even the rites of the Catholic Church are an interaction of signs, tokens and material symbols of faith, given their meaning by what is happening in the mind and soul of the believer. ${ }^{11}$ Scholar of online religious behaviour Cheryl Casey maintains that cyberspace is 'a uniquely appropriate medium' for religious rituals: 'By offering virtual presence from inside a virtual realm, ritual, as enacted symbol in cyberspace, is all the more effective at pointing beyond itself to the divine or the sacred. ${ }^{12}$ More emphatically, sociologist of religion Rachel Wagner argues that SL, in its totality, can be understood as a sacred space:

The computer defines its space (at least with current technology) with a window into which we peer - and into which we are invited to project our selves in some way or another. [...] One enters Second Life. One leaves Second Life. One shifts one's 'appearance' when one enacts one's avatar. One forgoes the ordinary needs of daily life when one enters - there is no eating, no sleeping, and no aging in Second Life. Some have even considered the possibility of inhabiting virtual space as a sort of digital heaven $[\ldots] .^{13}$

In this chapter, I argue that the divine visions of medieval saints are meditative experiences in which they access a similar kind of 'digital heaven'. Whilst the SL user logs on to this space via mouse-clicks and passwords, the medieval saint logs on to visions via devout prayer and contemplation. The modern worship experiences of SL Christians elucidate the experiences of medieval mystics, and vice versa. Clear parallels emerge between SL and vision space, as both are notionally disembodied realms, filled with live and authentic interactions. The offline user (body) and online avatar (spirit) can never fully be separated. There is a marked tension between orthodox and heterodox usage of SL as a religious space. The same issue troubles mystical vision space, a realm which potentially offers medieval holy women liberation from clerical control.

To begin, a brief overview of SL is necessary. SL is an internet-based virtual world designed to allow users ('Residents') to live out a fabricated 
version of life. ${ }^{14}$ Customizable avatars - virtual representations of the SL user in front of the computer - allow Residents to navigate the World and interact (via text-based instant messenger or voice chat). Residents can engage in hobbies, hold down full-time virtual jobs, buy land, create and trade virtual products, tour the virtual globe, and so on. Launched in 2003 by Linden Lab, SL has proved to be hugely popular, and claims to be the 'largest-ever $3 \mathrm{D}$ virtual world created entirely by its users'. ${ }^{15}$ Exact figures for usage of SL are not available, and it is difficult to determine consistent long-term usage of the site. However, as of April 2017, just under fifty million accounts had been registered..$^{16}$ Based on data from the first quarter of 2017, SL's daily concurrency (the amount of Residents logged-in per day) ranges from 53,000 to 31,000 users, with a median of 43,000 users. ${ }^{17} \mathrm{On}$ average, there are currently 8,000 to 10,000 new user signups for SL per day. In February 2017, Linden Lab reported 800,000 Residents are active in the environment per month. ${ }^{18}$ The last official statement relating to SL's economic buoyancy dates to April 2016. Ebbe Altberg, Linden Lab's CEO, informed journalists that SL's gross domestic profit (GDP) amounted to $c$. $\$ 500$ million, a GDP 'the size of some small countries'. ${ }^{19}$ Thanks to in-World transactions, SL businesses redeemed c. \$6o million in 'real' money in 2015.

In two interview periods, in 2011 and 2016, I conducted a research study within SL, asking a total of twenty-four Christian Residents about their religious worship online and offline. The excerpts from the interviews featured in this book have been anonymized, with only basic data appended. Where possible, a particular denomination is also attached to specific responses. This study was intended to offer a snapshot of Christian worship practices in SL, with responses garnered from across the denominational spectrum. To qualify for inclusion in the study, Residents must have expressed their religion online in some form in the six months preceding our interview, recognizing their activities as a meaningful part of their personal worship. The small sample size of the interviews means that the data are not statistically rigorous. Nevertheless, the results offer meaningful insight into this area of devotion, with Christians testifying, in their own words, about

On SL generally, see: Au, Making; Boellstorff; Meadows; Turkle, pp. 158-61, 192-93, 212-19.

Linden Lab, 'Homepage', n.p.

16 Linden Lab, 'User Statistics', n.p. As of 7 April 2017 (2.30pm), the number of registered accounts totalled 49,791,006, and 34,749 users were logged in.

17 Voyager, n.p. All statistics are derived from a database containing both historical and up-to-the minute SL metrics. For this, see: Shepherd.

$18 \mathrm{Au}$, 'Monthly Active Users', n.p.

19 Maiberg, n.p. 
how and why they practise in SL. Non-standard spelling, punctuation, and grammar in all quotations from interviewees and online message boards are preserved. Half of interviewees (twelve respondents) hold positions of religious leadership or are employed in some religious capacity offline. Moreover, over half of respondents (fourteen Residents) act as a spiritual leader or functionary in SL, undertaking tasks integral to the running of their religious community. Thus, the results from this study are necessarily skewed to present the attitudes of a highly engaged core of practitioners. The religious utility of SL is founded on the World's precise mechanics. In the following section, then, I situate the environment within media more generally, clarifying what makes SL unique as a representational space.

\section{Situating SL: Disentangling Television, Film, and Virtual Worlds}

Philip Auslander argues that television is understood ontologically as live, and the medium's 'essence' is grounded in the understanding of 'its ability to transmit events as they occur, not in a filmic capacity to record events for later viewing,. ${ }^{20}$ Though the majority of television is now recorded output, the medium's origin in live transmissions forms an ideological framework of 'liveness' which continues to this day. Television, then, is more akin to theatre than film. Whilst the latter may purport to capture live moments, the audience is never watching a truly live event as it unfolds. Disappearance is integral to live performances, televisual or theatre-based, as the event being watched immediately and ineluctably disappears from view, never to be seen again. ${ }^{21}$ By contrast, film - in viewing patterns of the modern audience - is based on repetition. The viewer can watch and rewatch the filmic 'present' event at will, by replaying a DVD or digital file over and over. Nonetheless, viewing movies more traditionally at the cinema contains a kernel of 'liveness' inasmuch as the spectator is having a specific experience of the film which was impossible to repeat in the era before VHS, DVD, and digital media streaming. Further, spectators in a movie theatre have a shared, unrepeatable experience by dint of the presence of other audience members in the screening room. In a footnote, Auslander acknowledges that interactive computer technologies - a grouping which includes SL - are also grounded in a sense of liveness', that is the immediate contact between user 
and machine, or in the case of SL, the 'live' contact between user, machine, and other users. ${ }^{22}$

For Auslander, an important facet of live performance is the disjunction between the audience and the performers. Whilst watching theatre, for example, 'provokes our desire for community', ultimately it 'cannot satisfy that desire because performance is founded on difference, on separation and fragmentation, not unity'. ${ }^{23}$ SL interactions challenge Auslander's propositions, in particular the 'unbridgeable distance between audience and performance'. In SL, users operate on the level of audience member and of the performer as the avatar 'performs' the user's offline identity in a shared space, populated by other avatars, whose users are equally engaged in 'performance'. The Resident is thus 'an active participant in constituting the spectacle. ${ }^{24}$ Moreover, SL is predicated on such user creation of 'action' in the World. In this way, it is 'more than just a game', as Marc Fetscherin and Christoph Lattemann affirm: 'there are no levels, no scores, and there is no "game over"'. ${ }^{25}$ Similarly, Bernhard Drax, a veteran documentarian of and expert in SL culture, underlines the fact that the World is 'absolutely not a game'. ${ }^{26}$ Rather, SL is an immersive digital ecosystem, in which user-created games may be played. Though virtual environments find parallels in television thanks to a shared 'ontology of liveness', the former is vitally constituted by user participation and interaction with the medium, which the latter can only partially mimic. ${ }^{27}$

In the previous chapter, I analysed the ways in which different audiences - fan bases - produce specific iterations of a celebrity or saint's identity, with reference to Marie of Oignies. Throughout the discussion, I emphasized Marie's lack of participation in constructing her celebrity image. SL users, by comparison, are highly dynamic producers of their own mediated representations. Helen Woods defines celebrity as 'being someone through the media, ${ }^{28}$ This exceptional classification breaks down with SL, and in the digital era more generally, as almost all of us are mediatized online in some form. Michael A. Stefanone et al. remark that 'social behaviors commonly associated with mediated celebrity are now being enacted by non-celebrities in an increasingly mediated social environment'. ${ }^{29}$ In other words, 'normal'

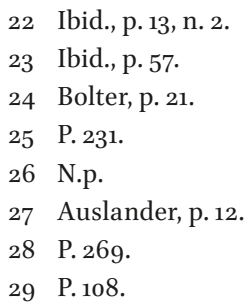


individuals are increasingly taking control over the mediation to which they could be subject - if only they were already famous. Technology offered by Web 2.0 is largely responsible for the proliferation of such self-mediated identities, with blogs, online virtual environments, and social networks offering internet users the chance to represent themselves as they see fit, without undue external interference $3^{30}$ Further, the internet allows for the dissemination of the self-directed representation across a much wider area than a non-celebrity could heretofore reach, as a disembodied virtual presence is accessible to anyone with an internet connection and the right hardware.

Although SL is clearly differentiated from film, Residents can be understood in terms borrowed from film production which relate to mediated performances: as 'vactors' (virtual actors) or 'synthespians' (synthetic thespians). ${ }^{31}$ These terms relate to computer-mediated actors, including performers wholly constructed by digital technology - such as those found in Toy Story (John Lasseter, 1995) - or hybrid performances, whereby computer representation is grafted onto an actor's body via motion-capture technology - such as with the actors playing the role of Na'vi aliens in Avatar (James Cameron, 2009) $\cdot{ }^{32}$ Barry King argues that Avatar stages 'the interaction between the filmic and pro-filmic realms'.33 An examination of Avatar's use of 'synthespians' affords insight into the interaction between the virtual and offline spaces which SL users negotiate. A brief recapitulation of the film's plot is necessary in order to understand the nuanced levels of performance at play. In 2154, humans have almost completely denuded the Earth of natural resources. A group of explorers financed by the government target the world of Pandora, a distant moon, in order to source vast stores of the mineral 'unobtanium' to sell for profit. Pandora is also home to a race of blue nature-worshipping peaceful aliens, the 'Na'vi', whose existence is threatened by human mining activities. To traverse Pandora and make contact with the locals, humans use hybrid human-Na'vi avatars: bodies which resemble the indigenous Na'vi race, operated remotely by a human's consciousness. A paraplegic former marine, Jake Scully (played by Sam Worthington), is the hero of the piece, initially tasked to infiltrate the Na'vi to secure information to help the mining activities. Ultimately, Jake sympathizes overwhelmingly with the Na'vi, with whom he bonds, even

30 On blogs, see in particular: Bruns, Blogs, pp. 69-99; Hevern. On mediated identities, see also: Annese; Dunn; Wood.

31 I borrow these terms from B. King.

32 On Avatar in this context, see: B. King, pp. 254-57.

33 P. 255. 
taking on a Na'vi mate (Neytiri, played by Zoe Saldana). He helps the aliens beat back the destructive humans, and finally becomes fully absorbed into his Na'vi avatar by contact with the connotatively mystical Tree of Souls, the focal point of Na'vi nature worship.

Bringing the Na'vi to the cinema screen was dependent on the use of performance capture. The performances of human actors in pro-filmic space - i.e. the space in front of the camera in which filmmaking takes place - were rendered into three-dimensional space by the use of various technologies, transforming the human visage and body into the Na'vi for the final product. Na'vi characters are a blend of human motion and emotion with digital effects: 'synthespians'. King elegantly summarizes the various 'vectors of reference' at play here: 'Sam Worthington performs directly with Zoe Saldana in pro-filmic space, but only with Neytiri on screen. He also performs in two modes, as his cinematic images (as Marine veteran Jake Sully) and as his digital image (as a Na'vi/human Avatar). Saldana only interacts with others (Avatars, humans and Na'vi) through the mediation of Neytiri. ${ }^{34}$ As a 'synthespian', Saldana can only interact with other characters in the narrative via her digital representation. SL users similarly connect solely via their avatars in virtual space. To exist in Pandora, a human requires an avatar. The same is true of SL. Nonetheless, the existence of Neytiri is dependent on Saldana's non-virtual acting and bodily form. Although side-lined in the field of representation, the human body is central to the entire operation. In the same way, a SL avatar cannot exist 'alone'. An offline body must log on to SL and direct an avatar's actions. In this manner, the Resident also parallels Jake's operation of his Na'vi hybrid form. Both Jake's consciousness and the SL user command a 'body' which allows for physical presence in a space that is impossible to access directly.

The capacity of SL to operate as a stand-in for Pandora is evidenced by the uptake of SL by certain Avatar spectators to enmesh themselves more meaningfully in the fictional world. In various Pandora sims, dedicated areas of SL fabricated to look like the 'real' Pandora in Avatar, Residents re-enact the film's narrative, more or less faithfully, through role-play. For a significant minority of moviegoers, Avatar provoked profound and relatively long-lasting emotional reactions outside of the gamut of affect a film might typically stimulate. Matthew Holtmeier describes an audience subsection as experiencing 'Post-Pandoran Depression' (PPD). ${ }^{35}$ PPD issues from an unfulfillable desire towards the screen and for the fictional world 
Figure 12 Second Life advertisement featuring Avatar-style avatar ('Navitar') from 2010

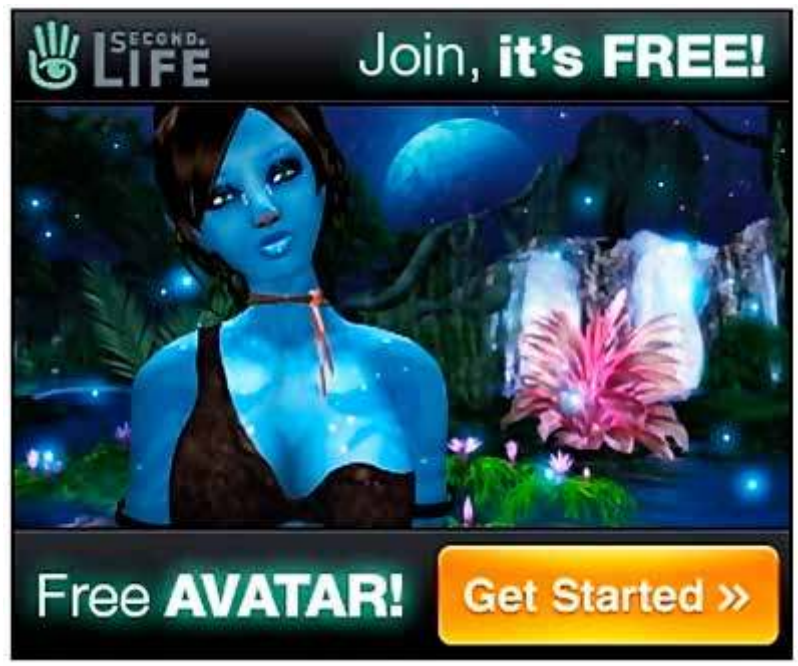

From Au, 'Lindens Advertise', n.p. Reproduced with permission of Linden Lab, Inc.

of Pandora, as spectators feel anguish at the impossibility of ever inhabiting the world themselves. The real world outside the multiplex is inferior; watching Avatar affords a dream-like space of plenitude and beauty. As one PPD sufferer comments in an online forum: 'After I watched Avatar at the first time, I trully felt depressed as I "wake" up in this world again..... ${ }^{36}$

PPD is based upon the perceived superiority of Pandora, alongside a lingering sense of the authenticity - the 'reality' - of the virtual world. Several commenters on the AVATAR Forums thread on coping with PPD write of the belief that they are Na'vi intrinsically, 'trapped' in a 'human shell'.37 'Dreaming' by watching Avatar equates, for at least one PPD sufferer, to a liberation from the human form and reincarnation in a true self by identification with characters onscreen, and a conflation of the offscreen individual's identity with the Na'vi on screen. ${ }^{8}$ Although it is impossible to know whether they are affected with PPD, some Avatar viewers have turned to SL to relive - and inhabit - the 'dream' more fully. Another selfidentified PPD sufferer opines that watching Avatar is not like typical film 
spectatorship: 'A movie doesn't give me these kind of feelings. Avatar was a whole new experience'. ${ }^{39}$ The virtual environment of SL offers a different means of interacting imaginatively with the film, and a means which parallels the 'whole new experience' of watching Avatar for some. By utilizing SL, Residents create their own immersive Avatar fanfiction.

Linden Lab utilized the notion of avatars specific to Avatar in advertising for the World shortly after the film's release (see Fig. 12 for an example from the campaign). ${ }^{40}$ During the period the advertisements ran, more SL users logged on and users spent more Linden dollars (L\$) in-World. ${ }^{41}$ It seems that SL tapped into a seductive parallel between the movie narrative and in-World experiences. As Avatar's hero, Jake, adopts an avatar to experience life on Pandora, spectators take up SL avatars to inhabit a virtual Pandora (or Pandoras) created in SL. ${ }^{42}$ By role-playing Avatar in SL, the SL user has an avatar in two senses: a three-dimensional representation which facilitates their existence in the World, alongside a 'Navitar' as the SL embodiments look identical to the Na'vi facsimile donned by Jake. SL allows for spectators to become 'synthespians' in a second way, this time operating seemingly from within the diegesis itself. Sam Worthington plays human Jake Scully, who then performs as the human-Na'vi avatar Jake. The Resident offline performs their identity as an avatar in SL, which then acts the role of a Na'vi.

Another similarity presents itself with SL 'Navitars' and actors in Avatar due to the mechanics of filming the movie. Whilst executing scenes highly dependent on computer-generated imagery (CGI) technology, actors could see their virtual representation on a screen (in Na'avi avatar form) whilst they performed a given action. ${ }^{43}$ This parallels the Resident's experience of being in their own body (offline) whilst also seeing their virtual embodiment operating in the World (as online avatar). Such functional coincidence between SL and film performance is rendered even more potent with the production of SL machinima based in the Avatar universe. Machinima is a neologism for 'machine cinema', film-making by recording scripted activities in a three-dimensional virtual world. ${ }^{44}$ In machinima, live avatar performances in SL are recorded with screen-capture software, and videos

42 For an overview of SL Pandora environments, see: Second Pandora. For insight into 'Navitar' usage, see: Oakleaf.

43 Reinhard, n.p.

44 On machinima, see in particular: Johnson and Pettit; Lowood and Nitsche (eds.); Ng (ed.). 
may be edited to add soundtracks and similar filmic elements. SL users have also produced Avatar-themed machinima, with Residents - as 'Navitars' - playing pre-defined roles different to their normal online identities. ${ }^{45} \mathrm{Be}-$ yond overtly adopting the role of director or editor in machinima, a Resident implicitly assumes similar roles normally found in film production as they control what is seen on the computer screen, including changing the viewing angle of the 'camera' which changes what is seen on the user's screen. Drax notes that film-making in virtual worlds entails a 'democratization' of cinema, allowing those without access to traditional funding streams to make their own content. ${ }^{46}$ For such creators, 'Second Life becomes [their] Hollywood studio'. By creating Avatar-based machinima in SL, Residents access Avatar in terms of film production, alongside meaningfully inhabiting the movie's diegesis on some level.

The examples above bring to the fore the conflation of three roles in SL which are typically segregated in pre-digital content consumption: spectator, performer, and producer. Axel Bruns deploys the term 'produsage' to delineate a new model of content creation and consumption in the Web 2.0 era which 'stands in direct contrast to traditional modes of industrial production'. ${ }^{47}$ The traditional production chain operates linearly from producer to distributor to consumer, leaving little to no flexibility for the consumer to intervene in the process. With produsage, the traditional consumer becomes both user and producer (hence 'produser'), playing an instrumental role in the entire process. Produsage is founded on four key precepts: 1) an atmosphere of inclusivity, which targets the participation of many individual users, and in which the user base collectively critiques contributions; 2) the attitude that all users are equipotential, leading to a flexible and non-hierarchical governance dependent on specific contributions at different times; 3 ) the dissection of projects into 'granular' tasks, leading to always-unfinished content which evolves gradually, with processes rather than outcomes privileged; 4) the ownership of created content by all produsers, both current and future. ${ }^{48}$

45 See, for example:AVATAR Second life. Part 1; The Birth of A Baby Na'vi Second Life (Zet'ey baby girl); SL AVATAR TO NA'VI (Escape To Pandora ).

46 N.p. Despite avowing the clear parallels machinima shares with more traditional film, Drax stresses that machinima is a specific 'artform' and deserves 'proper recognition' as such, perhaps as a new film genre or sub-genre of animated film. Some pieces of machinima simply allow creators to re-enact their 'Hollywood dreams'. Nevertheless, other pieces operate according to a coherent aesthetic regime, unique to the format and directly linked to the fact that machinima is a more 'democratic' creative endeavour.

47 Blogs, p. 9. On this, see also: 'Content Production'; 'Broader Framework'.

48 Bruns, Blogs, pp. 24-30. 
Bruns argues that SL 'harnesses the key principles of produsage', and even offers a vision of a future prodused non-virtual environment, as SL is successful in produsing artefacts, though they are simulated. ${ }^{49}$ SL's status as a prodused environment, at odds with traditional consumption models, contributes to a tension between labile spiritual expression for which the environment seems uniquely suited and authorized religious behaviours which correlate by and large with pre-digital models of top-down consumption processes. I elucidate this hypothesis more fully in the 'Agency and Dependency' section below. ${ }^{50}$

As Residents produse their virtual domicile, they also produse their own mediated identities. SL avatars are unfinished artefacts of identity, inevitably shaped by reactions from other users and the user's desired outcomes. All Residents have the same technology at their disposal in the creation of self-representational avatars, and at different times and in different ways may tap in to the zeitgeist of audience appreciation. ${ }^{51}$ For example, 'Navitars' seemed particularly noteworthy and cool - for want of a better word - in the months after Avatar's release, but have since waned in socio-cultural value in the World. Produsage is founded upon the power of users as a collective. It is an endeavour entirely based upon meaningful group participation in a shared environment, an environment created in large part because of the presence of users in the first place..$^{2}$ SL is not a game but instead an interactional space, which allows for the dismantling of geographical and linguistic barriers to bring users together for authentic communication. In a connotatively similar manner, medieval mystical space functions as a visualization of the interactive assembly of the communion of saints.

\section{The Online Communion of Saints}

Barbara Newman suggests that the space which saints access during visions is the communion of saints, a location which 'transcends space and time'.53 Belief in the communion of saints (communio sanctorum) is a basic tenet of

\footnotetext{
49 Ibid., p. 303. See also: ibid., pp. 289-312; Schneckloth, pp. 75-77.

50 Pp. 239-42.

$5^{1}$ Whilst this is true in theory, in actuality various factors may limit user equality. For example, user skills (or lack thereof) may mitigate the raw power of a given piece of software. Additionally, hardware is a limiting factor: users with slower internet connections, older devices and less advanced video cards will be disadvantaged in comparison to their peers. Such limitations typically lead to 'buggier' video rendering and increased lag time in online virtual environments. 52 Bruns, Blogs, pp. 289-9o.

53 'Preface', p. xl.
} 
Catholicism, expressed in the Apostles' Creed: 'I believe in the Holy Spirit, the holy [C]atholic Church, the communion of saints' ('[c]redo in Spiritum Sanctum, sanctam Ecclesiam catholicam, sanctorum communionem').54 Although found in vernacular forms in France from the ninth century, and formally adopted by Rome in the tenth century, the Creed has its origins several centuries earlier. ${ }^{55}$ The Latin phrase communio sanctorum generates uncertainty as to the precise signification of the precept. The word sanctorum can be read in either a neuter or masculine form, suggesting a definition of either the sharing of sacraments or an intimate bond between the pious respectively..$^{56}$ It was 'not an either/or option' in the Middle Ages, when the word was understood as having both meanings at once. ${ }^{57}$ Sacramental Communion equates to an ecclesial Communion, as the believer becomes one with the Church (and other believers) via union with Christ by ingesting the Eucharist. In its thirteenth-century inflection, the communion of saints was understood as 'the reciprocal contacts among the Church Militant on earth, the Church Suffering in purgatory, and the Church Triumphant in heaven'..$^{8}$ In other words, the communion of saints consists of the living, souls in purgatory, and souls in heaven: a collective of all those who have received sacramental Communion. In this assembly, all are commingled with the Lord, as expressed by Paul in Romans 12.4-6: 'For as in one body we have many members, but all the members have not the same office: So we being many, are one body in Christ, and every one members one of another.'59 Each Catholic becomes one with the Lord, a 'member' of Christ's body, whilst also completely united with all other believers. Intercession and intercommunication are central to the conceptualization of the communion of saints. The living's prayers could help a soul escape purgatory, and those in heaven can bestow grace on the living. Souls in purgatory visit the living to describe their torments, testifying as to the realities of the hereafter for a sinner.

Visions 'clarify the content of this world and the next', and mystical vision space operates as a realm in which the three spheres of the communion of saints come together and interact. ${ }^{60}$ In this way, the communion of saints is connected ontologically with television and SL, all three founded to

Denzinger (ed.), p. 27, DS 30.8 .

For earlier versions of the Creed in the Western Church, see: ibid., pp. 19-26, DS 10-29.

McGuire, 'Purgatory', p. 67; Pelikan, p. 174.

Boersma, p. 115 .

McGuire, 'Purgatory', p. 67.

Douay-Rheims Bible.

McGuire, 'Purgatory', p. 67. 
different degrees upon the notion of 'liveness'. The 'liveness' of visions is based upon their vital interactivity. The Liégeoises - and those of us reading or hearing about them, to some degree - see, converse, and frequently make physical contact with the dead, biblical figures, and even Christ in 'real time', or at least in a temporality that feels 'real', and thus inhabitable, to mortals. For example, Lutgard of Aywières is visited by many deceased former colleagues and acquaintances, including Innocent III; Master John of Liroux; Cardinal James; Jordan of Saxony, the Dominicans' Master General; the nun Yolendis; Simon, abbot of Foigny; and an anonymous spiritual sister. ${ }^{61}$ Biblical characters, angels, and saints also appear to Lutgard in visions. She sees and interacts with John the Evangelist; John the Baptist; St. Catherine; Marie of Oignies; and an unspecified multitude of saints, apostles, and angels. ${ }^{62}$ The Virgin Mary, Christ, and unnamed individuals sent by the Lord also repeatedly figure in her visions. ${ }^{63}$ In one of Ida of Nivelles' visions, the communion of saints is represented by a book of life from which she reads, allowing for a 'tangible' representation of the symbolic community to which she belongs. ${ }^{64}$ The mystical book contains countless painted images accompanying text which details the fate of individuals both alive and dead - existence in heaven, hell, or purgatory. That vision space is an assembly of the entire Christian community, the communion of saints, is further shown when saints see the spirits of the still-living in their ecstatic visions, as in Ida's book of life.

The communion of saints paradoxically exists both nowhere and everywhere. It is a spiritual, non-physical rendition of Christians' relationship with God, and an expression of the breadth of God's magnanimity. We are all located in Him, just as He is located within each of us. Visions allow for the amorphous communion of saints to have some form of location. The communion of saints is the 'there' which is accessed in rapture, the definitively 'not here'. This is shown particularly well when Lutgard of Aywières tells Christ, with whom she is conversing in rapture, to wait for her 'here' ('hic') whilst she 'logs off' and takes care of some earthly business: 'While she

61 Respectively: $V L A, 2.1 .7 .245 ; 2.1 .8 .245 ; 3.1 .5 .257 ; 3.1 .2-3.254 ; 2.1 .12 .246 ; 2.1 .4 .244 ; 2.1 .13 .246$.

62 Respectively: ibid., 1.2.15.240; 3.2.13.259; 1.1.9.238; 3.1.8.257-58; 2.2.29.250; 2.3.42.252; $2 \cdot 3 \cdot 42.252$.

63 For the Virgin Mary, see: ibid., 1.1.8.238; 2.1.1.243; 2.2.32.250; 2.3.42.252; 3.2.12.259; 3.2.13.259. For Christ, see: ibid., 1.1.2.237; 1.1.12.239; 1.1.13.239; 1.2.14.240; 1.2.19.241; 2.3.41.252; 2.1.6.244-45; 3.2.11.259;3.2.12.259. A visitation from an incorporeal Lord is also in ibid., 2.2.33.251. For unnamed individuals, see: ibid., 2.1.5.244; 2.2.17.247.

64 VIN, 18.243-44; Carpenter, 'Communities', p. 34. On the 'book of life' as a term for a specific hagiographical genre, and as Christ himself, see above: pp. 32-33 and 138-39, respectively. 
was sweetly joined to the Lord in prayer or contemplation and any urgent business called her away, she would speak to the Lord [...] [and say]: "Lord Jesus, wait for me here, for I shall quickly come back to you"'. ${ }^{65}$ Logging on to both SL and the communion of saints requires a 'user account'. For the SL user, setting up such a (basic) account is relatively simple, involving a computer and an internet connection with no costs incurred for the account itself. ${ }^{66}$ For the medieval saint, years of devotional practice coupled with God's grace bestow upon her an exclusive account, which she automatically uses when she experiences rapture. 'Logging on' in both instances involves a separation from those who do not have a user account, those who cannot enter the virtual space of SL or the spiritual realm and thereby interact with others who have also 'logged on'.

The dynamic of exclusion intensifies the perception of the virtual as a located, locate-able space - positioned just 'over there', through the computer screen. An individual not logged in to SL can, however, see when an individual is interacting with others on SL. The online SL user is sitting at a computer, often typing or voice chatting with other users, moving the mouse to manipulate an avatar. Similarly, onlookers who are not in rapture can see that a saint is experiencing ecstasy, 'logged on' to the spiritual space. For example, Eve of Saint-Martin hears Juliana speaking with the apostles Peter and Paul during an ecstatic trance ${ }^{67}$ For Eve, this is a one-sided conversation as she hears only Juliana's contributions, and is startled by Juliana's declaration of a journey to Rome to visit the apostles forthwith. This episode is also an example of the transcendence over time which characterizes the communion of saints, as Juliana talks in 'real time' with figures from a bygone era of the early Church.

Linear chronology is interrupted in the communion of saints, as it contains all Christian souls from history and contemporary times, alongside the eternal figures of God and His angels. Logging on to SL similarly requires the user to decouple from the time of the surrounding world and to accept a different chronology, as the environment's time zone is set as Pacific Time (PT). Until the end of 2006 , the time displayed in the SL viewer window was

65 VLAEng, 1.8.223. 'Verumtamen dum ipsa in oratione aut contemplatione Domino dulciter jungeretur, \& eam aliquod urgens negotium evocaret, [...] dicebat: Domine Jesu, expecta me hic: jam cito expedita revertar ad te'. $V L A, 1.1 .8 .238$.

66 SL also offers a 'premium account', currently costing between $\$ 6$ and $\$ 9.5^{\circ}$ per month (c. $£ 4.64-£ 7.35$ ) depending on the selected payment schedule. This account provides various extra benefits to the Resident, including a weekly stipend of $L \$ 300$ and their own home in World. See: Linden Lab, 'Premium Membership'.

67 VJC, 1.5.28.454. On this episode, see also above, Chapter 2, pp. 131-32. 
labelled as Second Life Time (SLT). Converters for manipulating SLT to the local time zones of users appeared online..$^{68}$ Instead of referencing PT, which is what the results are based on, converters typically list SLT results. SLT has an implicit status as its own, separate time zone, for a virtual location. SLT is synonymous with PT, but an increasingly global user base and subsequent confusion regarding the SLT acronym led to the switch.$^{69}$ Despite the switch to labelling the in-World clock in PT, all of my interviewees arranged meetings with me in SLT. This testifies to the fact that the dedicated time zone is clearly still prevalent with some users. Furthermore, SL has its own day/ night cycles. In a twenty-four hour period, there are six SL days, comprised of three hours of daylight and one hour of night. ${ }^{70}$

It is problematic to record a figure for the number of churches in SL. Things are always changing in the virtual environment: churches pop up and then disappear without a trace. Moreover, churches are not necessarily advertised to the broader SL user-base, making them hard to track down. A survey of the most current available data suggests, however, around twenty functional churches in SL of various denominations in the period 2009-2016. .1 $^{1}$ One source dating to February 2010 proposes a far higher figure: seventeen Catholic, five Orthodox, and sixty-one Anglican and other churches..$^{72}$ This inflated figure is, perhaps, due to the religious status of the listed sites. Some of these churches represent an architectural undertaking for their creators, and do not necessarily have any figuration as sacred spaces. ${ }^{73}$ Nevertheless, the creation of religious spaces can be an expression of faith. ${ }^{74}$ However, many SL Christians believe that a church is created from an assembly of religious individuals, not dependent on a physical or locate-able space. As two of the interviewees in my study assert:

\section{See, for example: Gemixin.}

69 Linden Lab, “SLT”', n.p.

70 In January 2016, Linden Lab confirmed plans to introduce a twenty-four hour cycle in-World, though a time-line for introducing the feature was not specified. Though the default setting for locations will remain the four-hour cycle, region owners will be able to use the longer cycle on their properties: Urriah, n.p.

71 On 1 August 2016, the term 'church' produced twenty results in the SL Places search: Linden Lab, “Church"'. Search results were screened to filter out churches used for explicitly nonreligious purposes, for example nightclubs, shops. The SL wiki, a crowdsourced help-guide for users, lists nineteen churches as of 4January 2016: 'Religious Places'. An in-World document also lists twenty churches as of 21 April 2016: Neva. For images of several churches, see Ganesvoort. For a study of the SL Anglican Cathedral and the Lifechurch.tv SL campus, see: Hutchings, 'Politics', in particular pp. 66-72.

72 Burt, 'Catholic'; 'Anglican'.

73 On this, see also: Grossman.

74 See, for example: Novikova. 
Figure 13 Author's avatar using a prayer pose in a Second Life Catholic church

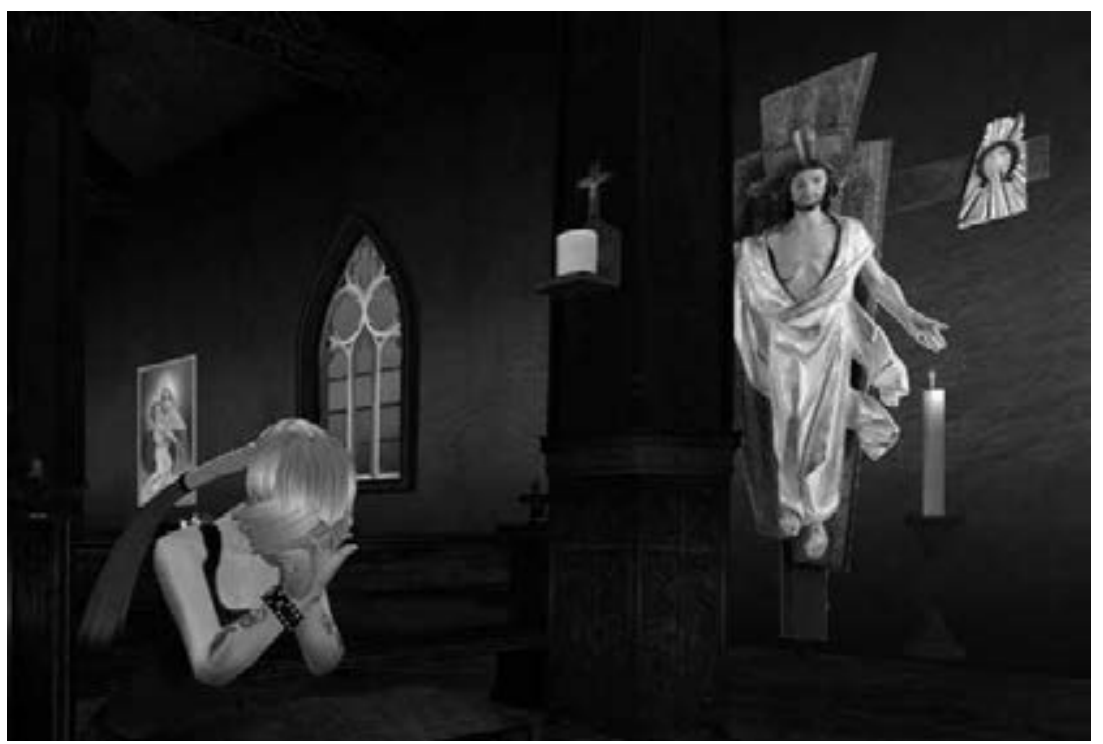

church is a gathering of God's people [male, 37, USA, non-denominational Christian (NDC); 2011]

But ultimately, a church isn't a building ---- it's the people *in* the building. ... Likewise ---- in Second Life ----- a church isn't the prims [virtual building blocks] that make the building ---- it's the people behind their computers who's avatars are in that prim-building. [female, 36, USA, Catholic; 2011]

The female participant quoted above implicitly distinguishes between the sacred space 'in that prim-building' and the profane space outside of its digital walls. For her, the church is a space walled off from the surrounding secular environment. However, what is significant about that walled-off space is the abundant presence of Christian believers, and it is that gathering which creates a sacred space as a by-product. The digital presence of an avatar, denoting the offline user's pious practice, is meaningful, and a space - even a virtual space - becomes sacred by means of the presence of devout Christians. Theoretically all of SL could become a church, if the virtual environment were populated by a flock of pious Christians focusing on God at the same time. The communion 
of saints is at least partially accessible in SL, inasmuch as interaction between countless living believers is possible in the World. The analogy breaks down, however, as neither dead believers nor divine figures can 'log on' - and these two groups are important members of the communion of saints. These collectives can only ever be partially accessed in SL through pious religious discussion and prayer by living Residents. For some, virtual graveyards and memorial sites in World act as lightning rods for mourning. Such installations can commemorate both deceased SL Residents and non-Residents, thereby lending a shadow of presence to even those most definitively 'offline' - dead individuals without a SL account. Residents' emotional connection to their 'offline' nearest and dearest works to apparate these departed souls in World: they 'log on' for those that, in death, cannot. In such cases, however, the full complement of the communion of saints remains un-realized. Though given presence - imaged and ventriloquized - in such memorials, the dead cannot speak for themselves. Nevertheless, social interaction is central to both SL fellowship and mystical visions, whose chief preoccupation is direct communication with the divine. In both spheres, 'virtual' communication is authentic and dynamic.

\section{'Logging On' to the Communion of Saints}

Mutual ecstasies - when both parties are 'logged on' to the communion of saints - produce reciprocal visions, in which holy individuals can interact despite being geographically separated. For example, a priest from Maagdendaal visits with both Ida of Nivelles and Christ during ecstasy. ${ }^{75}$ Through his devotion, and deep desire to form a more intimate spiritual relationship with Ida, the priest falls into rapture. In his first of two concurrent visions, he witnesses Ida taking Communion that day and her subsequent ravishment. In the priest's second vision, Christ directs Ida to share his grace with the priest himself, leading to a kiss between the two visionaries. ${ }^{76}$ Ida's visionary experiences are 'no less social' than her activities in the mortal

75 VIN, 27.266-69. On Ida's sociable visions, see in particular: Carpenter, 'Communities', pp. 3438 . Ida also has a relationship with another anonymous holy woman based on reciprocal visions which reveal the secrets of the other's heart, though the text does not explicitly detail meetings in shared vision space: VIN, 25.261. Cawley suggests the unnamed woman is Beatrice of Nazareth: VINEng, p. 70, n. 117 .

76 VIN, 27.267. 
realm: in both the spiritual space of visions and the tangible space of the mortal, she interacts with others regarding divine matters. ${ }^{77}$

Elisabeth of Spalbeek holds many meetings with Marie of Lille during their simultaneous raptures, though the two are physically distant: they 'used to see each other, since their ecstatic raptures frequently occurred at the same time. And furthermore, [she added] that she was getting to know her especially [well], stating that she was the wisest young woman and that she had a spirit of wisdom and counsel. ${ }^{78}$ Elisabeth's hagiographer, Philip of Clairvaux, maintains that the saint's knowledge of Marie's spiritual condition and ascetic suffering is authentic ('esse vera'), stating that he himself had verified it when passing through Lille..$^{79}$ The text emphasizes that Elisabeth had no knowledge of Marie through mortal means. The abbot himself was unaware of Marie, no rumours had reached the far distance from Marie's own community, and Elisabeth had categorically never seen her 'in real life'. ${ }^{80}$ Jesse Njus characterizes Elisabeth's experience here as a 'mutual vision that enables a virtual pilgrimage', in which the two holy women see each other 'in real time' despite being physically separated 'offline'. ${ }^{8_{1}}$ This mirrors the user experience of SL, in which users log on from various time zones in various locations, possibly never meeting in real life, and yet enjoy meaningful reciprocal social relations. The language barrier that would have separated the two medieval women in 'real life', with Marie speaking French and Elisabeth speaking Dutch, does not exist in the simultaneous trance encounters. In the communion of saints, as all are in the embrace of God, language differences are no longer an obstacle. The possibility of automatic universal translation is also present in SL. Various machine translators are available, whether provided by Linden Lab for free or as add-on devices sold in the SL Market Place (online store for virtual goods and services). Such applications, however, remain imperfect tools, in need of bug-fixes, vocabulary updates, and inclusion of more languages. The virtual space of SL is aspirational: the total demolition of all geographical and linguistic barriers is targeted. In medieval vision space, however, such boundaries simply do not exist.

78 VESEng, 24.2. 'Adjecit etiam de illa Maria quod frequenter concurrentibus earum raptibus mutuo se videbant, et quod optime cognoscebat eamdem, dicens quod illa erat sapientissima puella et quod ipsa habebat spiritum sapientiae et consilii.' VES, 24.376.

79 VES, 24.376.

8 o Njus, pp. 305-07.

81 P. 305. 
Holy women can communicate in a mystical lingua franca even outside of their visions. For example, Flemish-speaker Lutgard of Aywières transfers from Kerkom to Aywières, a French-speaking community, at the behest of God. ${ }^{{ }^{2}}$ The Virgin Mary ensures that the saint will never learn to speak French after her move. This is a positive event: it allows Lutgard to focus on contemplation, and ensures she will never be elected abbess. ${ }^{8}{ }^{8}$ The language barrier is not insurmountable, however. She is able to offer French-speaking visitors immense consolation by conversation, wondrously facilitated by the universal language of the Holy Spirit. ${ }^{84}$ The same spiritual communicative ability allows francophone Ida of Nivelles to understand the sermons of a certain religious Dutchman, though she is unable to comprehend her Dutch-speaking sisters at the time ${ }^{85}$ SL users cannot, of course, communicate in a similar translinguistic manner outside of the bounds of the virtual environment. The tools to facilitate such interactions exist only in science fiction, such as the 'universal translator' in the Star Trek television and film franchise or the 'Babel fish' in Douglas Adam's cult book series, the Hitchhiker's Guide to the Galaxy. ${ }^{86}$

The sequence of mutual visions between Elisabeth and Marie led to an intimate connection between the pair, testified by the fact that Marie is listed as a beneficiary of relics from Elisabeth and her relative, William of Ryckel. ${ }^{87}$ Njus maintains that the primary importance of the visions between the pair is that 'it allowed Elisabeth to overcome her disability virtually and to form a virtual, mystic relationship akin to that of Juliana of Mont-Cornillon and Eve of Saint-Martin' ${ }^{88}$ Elisabeth's capacity to overcome her 'disability', i.e. the deleterious physical effects of her extreme piety, through visions in which she interacts with Marie parallels the embrace of virtual technology by those living with disabilities to undertake activities otherwise inaccessible to them. The potential for SL churches and religious spaces to welcome those with social, physical, and/or mental impairments was mentioned by eleven interviewees during my study. Six interviewees themselves suffered such difficulties in attending church offline, and thus SL churches and/or religious spaces for expression allowed them to fill a gap in their (spiritual) lives. As one non-denominational Christian (NDC) commented: 'I have discovered hundreds of people from around the world,

82 VLA, 1.2.22.242.

83 Ibid., 2.1.1.243.

84 Ibid., $2 \cdot 3 \cdot 40.25^{2}$.

85 VIN, 2.205-06.

86 Loc. 1047-1120.

87 Berlière, p. 275; Coens, p. 409.

88 P. 306. 
that are shut ins, disabled, have social phobias, that cannot attend a RL [Real Life, i.e. offline] church, so for them, this is their Church' (male, 46, USA; 2011).

Njus explicitly equates the intense relationship - conducted in real life, in real time - of Juliana and Eve, documented in Juliana's vita, to virtual encounters in spiritual space. ${ }^{89}$ This is a remarkable assertion, given the exceptional closeness of the pair. Eve wrote the first version of Juliana's biography in French (c.1258-1261), upon which the later (c.1261-1264) Latin text is based, though the vernacular text did not survive past the seventeenth century.$^{90}$ The Latin text evokes repeatedly Juliana's interactions with Eve and visits to her anchorhold..$^{91}$ The vita states: 'They were in fact very close friends, being mutually bound by an unbreakable chain of charity. ${ }^{192}$ At the urging of Juliana, Eve devotes herself to God and becomes an anchorite, on the condition that her dear friend will visit her at least once a year. ${ }^{93}$ Juliana stays with Eve for a time after fleeing from the persecution of the Prior of Mont-Cornillon and his supporters. ${ }^{94}$

The spiritual community found in ecstatic visions is meaningful and authentic. Similarly, various researchers have concluded that online social communities in virtual space are real, despite the physical dislocation of users' offline bodies. Florence Chee et al.'s research shows that 'online communities [...] are no less real than communities in the world of fleshand-blood'. ${ }^{95}$ Fetscherin and Lattemann's study of SL Residents reveals that users are attracted to the virtual world precisely because of the possibility of genuine communication and collaboration, i.e. joining an authentic community.${ }^{96}$ Celia Pearce makes the same claim in her study of online virtual worlds: 'although the worlds may be virtual, the communities formed within them are as real as any that form in proximal space. ${ }^{97}$ Three quarters of the interviewees in my study (eighteen Residents) mentioned the capacity for

89 P. 306.

90 The dates for both the vernacular and Latin versions of Juliana's vita are taken from B. Newman's chronology, which precedes VJCEng, pp. 178-79.

91 B. Newman, 'Introduction' in, p. 155. For Juliana's visits to Eve, see: VJC , 1.5.22.452; 1.5.28$30.453-54 ; 2.1 .5 \cdot 45^{8} ; 2.4 \cdot 20.465^{-66} ; 2.5 \cdot 22.466$.

92 VJCEng, 1.5.22.209-10. 'erant siquidem ad invicem familiarissimae, ut pote inter se colligatae indissolubili vinculo caritatis'. VJC, 1.5.22.452.

93 VJC, $1.5 \cdot 22.45^{2}$.

94 Ibid., 2.5.22.466.

95 P. 160.

96 P. 240.

97 P. 17. 
global fellowship as a draw to practising their religion in SL. ${ }^{9}$ SL Christians tap into one segment of the communion of saints, other living believers, by fellowship with them online. The capacity to interact in real time with other Christians, forging authentic relationships, was integral to their decision to practise Christianity online. The importance of fellowship with other Christians was also evoked by many respondents when describing their motivation in going to church offline.

SL enables fellowship, a mainstay of Christian community and worship, on a much larger scale. The virtual environment is not remaking worship practices anew, but instead furthers existing conventions and patterns with the aid of modern technology. However, the closer connection with fellow believers in SL compared to those within the offline community was noted by several respondents in my study. For example, one respondent commented that "[s]ome of my best friends here do not even live in the USA and $i$ have better fellowship with them than my next door neighbour in rl [real life, i.e. life offline]' (female, 35, USA, NDC; 2011). Physical and social isolation often affects holy women too. As discussed in the general Introduction above, the Liégeoises all experience some form of friction with the community around them, even in enclosed monastic spaces ${ }^{99}$ Reciprocal mystical visions offer the women 'better fellowship' with like-minded individuals, or rather other people of similar religiosity and spiritual lifestyle - even if those pious compatriots are long-dead, or divine.

\section{Of Avatars and Offline Bodies}

Fellowship, be that in SL or in vision space, demands (virtual) embodiment. As Pearce puts it, 'you cannot observe a virtual world without being inside it, and in order to be inside it, you have to be "embodied". In other words, you have to create an avatar. ${ }^{\prime 100}$ The Oxford English Dictionary supplies various definitions for the word 'avatar', including '[m]anifestation in human form; incarnation', and '[m]anifestation or presentation to the world as a ruling power or object of worship. ${ }^{101}$ Caroline Walker Bynum

98 The draw of global fellowship for online worship is revealed in other studies. See, for example: Hutchings, 'Creating Church', pp. 205-06, 214; Robinson-Neal, p. 241.

99 See: pp. 34-36.

100 Emphasis in original; p. 196.

101 'avatar, n.', n.p. 
asserts that the later Middle Ages are characterized by an 'intensification of materiality in all aspects of the visual', including in written descriptions of holy visions. ${ }^{102}$ Descriptions of visions, particularly those of holy women, are 'filled with concrete objects'. ${ }^{103}$ These objects facilitate an understanding of the divine in the limited mind of the mortal believer. The 'concrete objects' populating medieval divine visions are manifestations of God. God, His essence, and other divine figures are embodied either in human or object form.

'Concrete' in the context of medieval divine visions also translates to 'tangible' or 'appreciable to the senses', rather than just an abstract spiritualized - non-corporealized - vision. For example, Lutgard of Aywières sees Christ 'in that human form in which he had once lived among mortals'. ${ }^{104}$ Pulling back his garment, Christ shows the saint the still-bleeding wound in his side from the lance that pierced his body at the Crucifixion ('vulnus lateris ostendit, quasi recenti sanguine cruentatum'), implicitly referencing John 19.34. Likewise, Christ appears to Margaret of Ypres 'plainly in visible form' ('plane in forma visibili') with a crystal vial. ${ }^{105}$ Two references to Christ's hand ('Christus manum [...] in manu Domini'), which holds the crystal container and lifts it to Margaret's lips, make his human form explicit. Such examples of spiritual embodiment in the space of divine visions can be characterized as avatars. This connects the holy women with SL Christians, equipped with avatars in a different sense, as 'graphical representation[s] of a person or character in a computer-generated environment'. ${ }^{106}$ Both SL avatars and mystical avatars render authentic religious states and precepts visible.

From a medieval perspective, the 'other setting' in which avatars function is the spiritual space of the divine, the communion of saints, accessed by the saint through devotion and ecstasy. Pearce asserts that

Research has repeatedly revealed that players [of online games] often perceive their avatars as a medium through which one's soul, one's deep inner persona, is expressed, even though the avatar's personality may be quite distinct from that of the person controlling its agency. ${ }^{107}$

102 Christian Materiality, p. 121, p. 127.

103 Ibid., p. 41.

104 VLAEng, 1.2.218. 'apparuit ipsi Christus in ipsa humanitatis forma, qua inter homines quondam fuerat conversatus'. VLA, 1.1.2.237. See also, ibid. 2.

$105 V M Y, 42.125$.

106 'avatar, n.', n.p.

107 P. 22. 
In the virtual space of SL, Christians across the world can not only represent themselves authentically as spiritual individuals, but also interact with each other. Thus, for some SL Christians, the virtual environment also corresponds to the communion of saints in one significant way: fellowship with other living Christians in an environment which transcends the physical limitations of geographic distance and time differences. This allows SL to become, in the words of a Roman Catholic respondent, 'a power house of prayer' (male, 55, Australia; 2016). In SL, as in mystical vision space, there is always somebody there to hear your prayers.

The 'other world' accessed by both SL user and medieval saint during visions problematizes the understanding of what it is to be embodied, allowing a move away from a strictly binary model of flesh versus spirit to see the complex interactive processes at play. Creation and operation of a (computer) avatar is 'the beginning of a life' in an online environment, including the beginning of a user's Second Life. ${ }^{108}$ As an avatar cannot exist without the user who created it, the user cannot access, and thus exist in, the virtual space of an online world without an avatar. Moreover, accessing a virtual environment involves embodiment and disembodiment, and stages of slippage in between. Thomas M. Malaby concisely captures the complexity of avatar/user relations in two sentences: 'I look at my avatar. It is (I am) not naked. ${ }^{109}$ Malaby's parenthetical 'I am' may refer to his offline body - whilst he looks at his clothed SL avatar, his offline physical body is also clothed. 'I am' may also appertain to his avatar itself, alluding to the shift from object to subject entailed in looking at 'oneself' (one's avatar) as an object decidedly outside of one's own physical bounds, yet also belonging to oneself, an object-being that is nevertheless meaningfully oneself. Malaby looks at his avatar and the traditional visual economy of subject (viewer) and object (viewed) is played out. Yet, with his parenthesis, this economy is unpicked and challenged: the 'it' of the viewed object is also the viewing subject 'I'. Moreover, that avatar 'I' can also 'look at' other objects within SL, head positioned to take in scenery and other avatars. Where the body of the avatar goes, so does its digital eyes, and thus what Malaby is looking at on screen is dictated by what his avatar is looking at, that at which he chooses for his avatar to look by using a keyboard or mouse. Are Malaby's eyes led by the avatar's eyes, or vice versa? Where does the balance of power lie in the avatar-human interaction? As the offline human shapes the avatar's appearance and 
guides its behaviours, the avatar moulds the experience of the offline user. This functionally replicates the co-dependency of flesh and spirit that is so central to Catholic doctrine. What happens to the body indubitably impacts the soul: sinful conduct on earth leads to eternal damnation. However, the soul equally exerts power over the body. An appropriate spiritual attitude directs the trajectory of a pious believer's life, and a worthy soul may receive divine grace in the form of miracles which mark the body.

The medieval individual is conceptualized as a personhood fabricated from both spirit (the digital) and flesh (the corporeal). In a mystical vison, St. John explains to Yvette of Huy why a certain priest refused to give her Communion, as she had wished: "[The priest] did not dare to touch the holy Body of Christ [corpus] because recently he killed his own body [corpus] and he killed his soul by making his body [corpus] one with that of a whore."'110 The chiasmus 'suum corpus interfecerat, interfeceratque animam suam' highlights the inescapable bond between body ('corpus') and soul ('animam'). Sinful conduct leads to the death of both spirit and body. Corpus is emphatically repeated in three different contexts: the body of Christ in the Eucharistic wafer, the priest's body as mortal matter, and the priest's sinful indulgence of intimacy with the sex worker. The body of the priest is syntactically placed between two possible unions: one with God by contact with His son's flesh, and the other a sinful coming together of the priest and the sex worker. This evokes the priest's status as an example of a mortal man, existing on a spectrum marked at its extremes by spirituality (Christ) and physicality (the sex worker).

Explaining their understanding of the relationship between online avatar and offline body, several respondents in my study referred to the status of the avatar as a projection, and representation, of their offline selves. The avatar is repeatedly figured as intimately and indefatigably intertwined with the offline individual, not a separate entity." For example:

We are not separate. My avatar is an expression of who I am. Therefore, when my avatar is praying that is simply me praying [female, 58 , UK, Anglican; 2011]

110 VIHEng, 34.96.126. 'Ausus non fuit sanctum Christi corpus tangere, quia recenter suum corpus interfecerat, interfeceratque animam suam factus vnum corpus cum meretrice.' VIH, 34.96 .881 .

111 Drax notes, however, that SL content-creators typically view their avatars more practically, 'like a machine' they must use to have a presence in-World (n.p.). 
for me, [my avatar] represents on the screen, what my heart is doing in RL [male, 46, USA, NDC; 2011]

the av [avatar] is just a representation of myself being here. it represents who I am thus I dress and act accordingly as I would in RL [...]

being a different av doesnt change my perception of my faith, that comes from inside. [female, 35, USA, NDC; 2011]

The virtual body of the SL avatar, then, is a means of communicating the internal mysterious actions of the spirit that are taking place in the Christian's offline body, or the spirit's otherwise invisible presence travelling across wide geographical divides via the internet. The avatar is necessary to give some form of presence to the spiritual and social connection at play in SL, as it allows the human mind something to grab hold of to better understand and immerse itself in the virtual experience.

One male North American Mormon (LDS) Resident (2011) has a beautiful preadolescent boy as his avatar, despite being in middle age in reality. Explaining this particular choice, he links his youthful avatar to his faith: 'Well - as you can see, my avatar here is childlike. I like to think it fulfils the Savior's admonition we become as little children. A form of "sack cloth and ashes" I suppose. In RL [Real Life], when I pray, I Imagine myself as a little child before God'. In his reference to becoming 'as little children', the respondent evokes Matthew 18.3: 'Amen I say to you, unless you be converted, and become as little children, you shall not enter into the kingdom of heaven. ${ }^{\prime 12}$ Whilst one may meditatively become child-like, it is impossible to do so literally offline. However, SL allows for a partial realization (visualization) of this rhetoric. The incomplete realization is nevertheless meaningful, more potent than meditative infantilization alone - particularly so given that the Christian exists only as a child in SL, and thus his whole in-World identity hinges upon his child-like self-representation. The man's avatar is an authentic representation of his personhood as it reflects his spiritual self. His avatar permits him to follow literally the Lord's guidance and become as a little child in His embrace. This avatar is a (virtually) physicalized rendition of the Christian's interior (spiritual) condition: a digital expression of his 'true' identity equal, if not superior, to his offline physicality. ${ }^{113}$ 
Representations of a holy woman in visions or after death allow for the interior workings of the spirit to be rendered visible. For example, Alice of Schaerbeek's soul is seen as having the body of a little child ('modum parvuli pueri'), illuminated by divine rays, in a vision after her death. ${ }^{114}$ During her life, Alice suffers the torments of leprosy, and the disease progresses to such an extent that her body breaks down, oozing pus and emitting a terrible odour. ${ }^{115}$ Yet, the saint glories in her corporeal disintegration as a means to experience pious suffering and thereby come closer to God. As a girl sees Alice's soul as a divinely lit child, it is understood that, finally, the saint's interior spiritual condition is being manifested in her outward appearance. A parallel operation, then, takes place with the medieval transformation of the withered Alice into a beautiful child and the modern LDS interviewee's adoption of a child-like avatar. Such reversal of values resonates with Pauline scripture, in which the apostle expounds again and again on the inversion of societal norms leading to the believer's identity as 'in Christ'. ${ }^{116}$

In II Corinthians 4.16, Paul emphasizes that a Christian's appearance is predicated on a split between interior and exterior states: 'though our outward man is corrupted, yet the inward man is renewed day by day'. ${ }^{117}$ Alice and the LDS Resident's child-like spiritual/virtual appearance - in combination with their apparent literal or metaphorical 'corruption' - function as visualizations of Pauline rhetoric. From another perspective, the vision of Alice as a child potentially reveals more about her community (La Cambre) than the woman's soul. The community is encouraged to understand the horrific degradation of Alice's body as a paradoxical marker of wholeness and holiness, despite the inevitable feeling of repulsion due to the woman's bodily breakdown. A vision of Alice's soul as a child testifies to the rectitude of this prescribed meaning, and retroactively lightens the burden of uncoupling an immediate response to Alice's body (shock, disgust) from the 'correct' attitude (joy, inspiration). Pauline rhetoric is authorized and concretized by the vision.

To understand Alice's appearance, one must decipher its symbolism, which authentically represents her interior state. Avatars too must be 'looked through', as they connote the user's spiritual and intellectual presence 'behind the computer'. Avatars, as virtual embodiments, render the

114 VAS, 3.34.482. See also discussion of Alice's condition above: Chapter 1, pp. 102-04. On this specific episode, and Alice's leprosy as an affirmative experience, see: Spencer-Hall, 'Projections', p. 63; 'Suppurating Wounds'.

$115 V A S, 3 \cdot 31.482$.

116 Nguyen, p. 210.

117 Douay-Rheims Bible. 
'offscreen' body and devotional actions of the SL user visible, but cannot and do not stand alone as spiritual objects. The word 'icon' can refer to a devotional depiction of Christ or another holy personage, worthy of adoration as an authentic imaging of divinity or, more simply, an 'image, figure, or representation. ${ }^{\prime 18}$ In Christian worship in SL, avatars operate as icons, representative (virtual) symbols of a Resident's offline - physical, and at times, spiritual - personhood. Discussing the religious significance of virtual iconography in SL churches, another Catholic interviewee comments that '[i]kons [in SL] display the same imagery as they do anywhere else. ... An ikon is a window to heaven. Don't look at it ---- look *through* it' (female, 36, USA; 2011). Similarly, a saint functions as a window through which we access God. We worship through identification of the saint as a conduit for the divine, but do not worship the saint as an individual personage per se. As Brigitte Cazelles notes, saints are 'de facto interchangeable'('de fait interchangeables'). ${ }^{119}$ They are products of a specific framework of Catholicism which underscores the advantages of spiritual role models to inspire the laity, and of the capacity for the particularly religious to act as intercessors.

The avatar operates as an intercessor par excellence. It can be everywhere, all the time, thanks to its transmission over the internet, cutting across all geographical locations and temporal zones. Capable of taking on any form, the avatar is endlessly fluid, of flexible shape and design. Nevertheless, the avatar is an attribute of a human offline, and it is this human who manipulates the boundaries of space it traverses, its articulations, and the physical form it takes. The avatar and its user cannot ever be fully disassociated. To all intents and purposes, the avatar is the user's digital soul, secularized only partially by its evocation through the means of technology, that oh-so 'rational' and 'scientific' human development. Technology may not be religious outright, but it certainly is spiritual. ${ }^{20}$ We may shed the Catholic theology of body and soul, but we cannot divest of its underlying rationale, the roiling magma which lies underneath its doctrinal crust. We have simply changed the materials with which we terra-form the unstable earth beneath us, that grounds us as human subjects. Body and soul, body and mind, online and offline, real and virtual: none are binary oppositions. Coded according to different socio-cultural contexts, all these mutually constitutive pairings nevertheless express the

118 'icon, n.', n.p.

119 My translation; Corps, p. 13.

120 On this, see also comments at the end of Introduction above, pp. 62-63. 
same compulsion to try to figure out what it really means to be a human subject in the world.

\section{The Agony and the Ecstasy of Technology}

Laura U. Marks asserts that technology, computer hardware and software, produces intense physical and emotional responses in its users: 'When your computer jitters and crashes, do you not bleed too? Does the aborted connection remind you of your tenuous hold on this world? When your computer sprouts a rash of warnings and mindless confirmation messages on its face, do you similarly grow hot and bothered? I know I do.' ${ }^{121}$ The actions of the malfunctioning machine, accidentally user mandated or unfathomably issuing from the computer itself, stimulate physical and affective sensations in the body in front of the screen. What is happening inside the computer's processors, or on its screen, may be 'virtual', but the reaction it provokes is material. Studies show, for example, that online gaming has various physical effects, including loss of sleep, pain from playing for long hours, and the development of fine motor skills. ${ }^{122}$

In addition, some Residents living with chronic illness consider time in-World to be a powerful addition to more traditional medical interventions. ${ }^{123}$ After being diagnosed with Parkinson's disease in her early 8os, Fran Serenade joined SL. ${ }^{124}$ She derives great joy from her in-World activities, typically undertakings to which her condition precludes participation in real life, such as ice-skating, or experiences that are impossible to have offline, such as swimming as a mermaid. Such activities, Fran believes, therapeutically increase her dopamine levels, which Parkinson's can negatively impact. SL also engenders in Fran a renewed sense of self-confidence: if her avatar can do it, so can she. Since joining the World, Fran has become more physically capable, despite her symptoms. Fran's daughter, Barbie Alchemy, has created specific environments for Parkinson's sufferers in SL to allow others access to similar medical benefits. Barbie credits SL's iatric efficacy to the operation of mirror neurons and neuro-plasticity, the ways in which the brain creates new pathways based on visual stimuli, and thereby 'rewires' itself to (re)gain function.

121 Touch, p. 191.

122 Chee, Vieta, and Smith, p. 169; Malaby, p. 22.

123 Drax.

124 The Drax Files. 
Fran and Barbie's anecdotal experience is borne out, broadly, by recent clinical research. In a 2016 study from Duke University, paraplegic patients recovered a significant amount of mobility thanks to brain-machine interface technology. ${ }^{125}$ The treatment modality was based on a combination of 'intense immersive virtual reality training', 'visual-tactile feedback', and the usage of robotic exo-skeletons. ${ }^{126}$ Patients were initially tasked with controlling the motion of a digital avatar with their minds. The brain's electrical signals were translated into computer input. The 'offline' body controlled the 'online' avatar. The latter, however, also made itself 'felt' in a meaningful way. Patients received sensory feedback on the forearm, to mimic roughly the sensation of taking a step corresponding with the avatar's movements. This neurological-virtual (re)training later allowed patients to re-create the avatar's movements outside the digital environment: by controlling a robotic-exoskeleton with their mind, they could then walk in the real world. Although no longer visible, the avatar lives on as part of the patients' 'offline' body. The avatar functionally resides in the patients' brain, in the form of the new, or regenerated, neural pathways that fundamentally underpin their increased locomotive capacity.

The visual animations of avatars are controlled by the offline user. However, these animations exert a form of control over the offline body too. This interplay of user-technology agency is intensified for the Liégeoise visionaries, as for them, the virtual realm is more real than the normal 'offline' world, which offers only shadows of God's majesty. The 'offline' saintly body is secondary to the spiritual avatar which operates in the truly authentic hereafter; the software has the upper hand. In terms of the Duke University study of paraplegia: the primary goal of the saint is not to (re)gain mobility in the 'offline' world, but rather to use the real world ('offline') to increase their abilities in the 'online' world. The holy woman pivots to the real world ('offline') in order to increase her spiritual facilities in the 'online' realm of God's grace. Nevertheless, the saint's body is always involved in some way in virtual activities. The saint's virtual existence is routed through the body, and occurrences in vision space are shown to affect her body intensely. What's more, the saint's body is frequently the means by which she develops in piety sufficiently to acquire a 'user account' for the virtual-spiritual space, for example as a result of asceticism.

In SL the virtual experiences of Christians are believed, by some, to leave a mark on the Resident's offline body. With religious worship online, via a 
machine capable of making the user emote and physically feel the grace of God, Marks' formulation of the physicality of interfacing with a machine is amplified even further. The majority of interviewees in my study do not believe that the highly physical rite of Communion is fully possible or appropriate in SL. Only four Residents (one NDC, one Pentecostal, and two UCC) consider the online and offline rite to be wholly equivalent. In UCC Communion services, Residents are instructed to ready themselves offline with sacramental elements, such as a piece of bread and some juice. The clergy-member leading the service indicates to SL congregants when to partake of the appropriately transformed elements offline, whilst worshippers' avatars remain seated in the in-World church. Although conducted over the internet, UCC Communion very much depends on the offline world. UCC avatars do not ingest a digital form of the sacramental wafer and wine. Rather, SL offers a means to connect an ordained minister to a geographically dispersed flock: the cleric's consecration flows through the virtual into the corporeal offline world, affecting the literal bread and juice that a Resident has collected.

A belief in consubstantiation grounds the UCC acceptance of Communion in SL. Sacramental elements are already understood as being virtual manifestations of Christ's materiality in the offline world: 'The elements are symbolic representations as opposed to actually being body and blood' (male, 73, USA, UCC; 2016). The authenticity of the virtual rite necessitates that a 'real' clergy-member (i.e. an individual ordained offline) leads the service. Indeed, all those representing themselves as ministers in the UCC SL church (FUCCSL) are 'really' ordained offline. Moreover, FUCCSL is the first in-World worship space to be authorized by its governing denomination, identified as a 'Ministry of the Southern California Nevada Conference' of the UCC since its inception in October 2013. In November 2016, it became the first SL church to achieve full standing by ecclesiastical authorities as a 'real' church, as a member of the Eastern Association of the UCC Southern California Nevada Conference. ${ }^{127}$ This recognition legitimizes - for want of a better word - FUCCSL and its associated worship praxes. Virtual Communion is valid for UCC Residents as it is authorized explicitly by the UCC clergy that offer it, and implicitly by the UCC governing body that has approved of the denomination's activities in-World.

By contrast, the Vatican rejects online Communion in strident terms: 'Virtual reality is no substitute for the Real Presence of Christ in the 
Eucharist, [...]. There are no sacraments on the Internet'. ${ }^{128}$ Most Residents I spoke with, both Catholic and non-Catholic, were similarly wary of the loss of materiality implied by virtual Eucharistic experiences. As a Methodist minister elucidates: 'the sense of connection with God in Communion can be experienced here, but the base physicality of these signs and symbols are not really possible here' (male, 40, UK; 2011). Nevertheless, if Communion in SL were entirely meaningless, there would be no need to avoid the practice or struggle with its implications. As several of my interviewees remarked: virtual Communion is potentially valid in a spiritual sense, yet impossible to be achieved physically (sacramentally). It is authentic yet also somehow inauthentic, qualitatively different to the same rite offline, even if the same spiritual gestures take place. A Roman Catholic respondent (male, 55, Australia; 2016) points out a seeming inconsistency in the Church's prohibitive stance on virtual Communion. In fact, the Church does recognize that spiritual Communion is authentic, at times. For example, it is advocated as a means of Eucharistic devotion for those who cannot attend mass, such as the sick and the elderly. The validity of spiritual Communion is witnessed by pronouncements made at the Council of Trent. ${ }^{129}$ In 1551, the Council designated three forms of Communion: sacramental (ingestion of the Eucharist by sinners, absent any commitment to piety), spiritual (fervent desire for the Eucharist by the pious, absent the literal sacraments), and both sacramental and spiritual (ingestion of the Eucharist with appropriate veneration by the faithful). Whilst the latter is implicitly superior, the former two options are at least partially authentic. And spiritual Communion, in which the communicant receives God's grace, is surely better than the condemnation that sinners obtain via sacramental Communion alone. Why, then, does the Vatican prohibit virtual Communion, with its clear resonance as a form of spiritual Communion, so vehemently?

This is murky doctrinal territory, hinging on complex distinctions between, on the one hand, the spiritual and the virtual, and on the other, the sacramental and the notionally 'real' (offline). The interview responses of an Anglican Resident (female, 40, Australia; 2011) shed light on the ways in which lay believers deal with such ambiguity. Line by line, the theological and personal reasoning of one Christian take shape:

128 Pontifical Council for Social Communications, 'Church', II.9. On this, see also: Spadaro, Cybertheology, pp. 71-92

129 Denzinger (ed.), p. 396, DS 1648. On spiritual Communion as a potential 'solution' to the conundrum of virtual Communion, see: Spadaro, Cybertheology, pp. 75-76. 
Let's take Communnion.

[The priest] cannot consecrate bread and distribute it.

But

If I were to have a little bit of bread here, and a little bit of wine and if he were to say the Words of Institution

...

$\mathrm{Hmmm}$.

That would take a stretch of my imagination to consider that legitimate. Still, if this were the ONLY way I could attend church, it would be better than no Communion.

It challenges my ideas of meeting, of community.

Does the priest need to be physically present for the prayers to be effective?

$[\ldots]$

I suppose. then, the same might be said for other sacraments.

Baptism

But it would be a biggers stretch again for, say Confirmation

Because the Bishop is meant to actually lay hands on you.

I think confession and absolution are fine.

The performance of virtual religious rites challenges this Christian's understanding of her faith practice. Yet, she understands that virtual Communion - if absolutely necessary - does have a certain spiritual value, better than no Communion at all. Later in the interview, she poses a series of questions, interrogating her personal viewpoint and Church teachings on the issue further:

Why can a virtual community that has supported a person through their spiritual journey, not be able to pray them through baptism, confirmation, and beyond?

I do not believe that God is constrained by the laws of time and space, so why should we feel the need to all be in the same place for God to be among us?

She concludes by determining that, ultimately, it is God, and not clerical officials, who 'bestows' the sacrament. Theoretically, then, her earlier position has been overturned. If God, in spirit, is outside of time and space, then He can operate successfully in a virtual environment. This attitude clearly positions the Resident outside of orthodox doctrine, which demands the ministrations of a cleric for sacramental rites. Drawing from the Liégeoises' 
example, I hypothesize that the female respondent's gender plays a role in her thinking. Disconnecting the sacraments from clerical control allows her, as a woman, to have an unmediated relationship with God without interference from the clergy. Paradoxically, this more direct link to the divine occurs in the highly mediated space of SL. In the virtual world, however, she chooses the kind of mediation (and mediatization) to which she is subject - avatar style, forms of interaction with fellow users, personal faith, and decision to $\log$ on..$^{30}$

The form of virtual Communion, direct from God, imagined by the female SL user discussed above is paralleled in the biographies of various saints who receive the Eucharist in their mystical visions. Margaret of Ypres, for example, receives Communion directly from Christ during a spiritual vision. ${ }^{131}$ Though her Eucharistic experience explicitly takes place during ecstasy, it is real and leaves a physical trace. Margaret is able to taste and chew the sacramental wafer present in her mouth, even once she returns to her earthly senses: "The Lord gave her a share in his own body under the species of bread, and afterward she revealed to her spiritual father this certain proof: what she received outwardly in her mouth, she chewed with her teeth and tasted for as long as its material form remained. This grace stayed with her for fifteen days. ${ }^{1{ }^{132}}$

In a mystical vision, Lutgard of Aywières ingests Christ's blood directly from the wound on the right side of his crucified body. ${ }^{133}$ This is a parallel, even superior, form of traditional Communion, which clearly troubles doctrine on the necessity for clerical intercession in the performance of the rite. The holy woman does not need to perform the meditative work to comprehend the reality that the Eucharistic wine is Christ's blood, as she drinks it directly from the source. She experiences the 'substance' of the sacrament, without having to deal with its superficial and occluding 'accident'. The physical effect of this virtual spiritual moment is highlighted by the text's author. After this experience, the saint is 'always stronger and quicker in the service

130 Cf. discussion of agency in choosing the terms of one's own mediatization in Chapter 3 , with specific reference to Kim Kardashian West: pp. 177-79 and 181-87.

131 For similar examples of mystical Communion, see VBN, 3.2.193.224; VES, 19.374 (implicit); VILéau, 2.20.113; VILov, 1.4.20.163, 2.2.9.173, 2.3.12.173-74, 2.6.29.178-79, 3.1.2.182-83, 3.1.5.183, 3.1.7.183-84; VIN, 8.218-21; VIH, 34.96.881. On this motif in Ida of Léau's biography, see also above: Chapter 1, p. 76. More generally, see: Bynum, Holy Feast, pp. 228-33.

132 VMYEng, 24.186. 'Cui quippe Dominus sub corporali specie panis participationem sui Corporis dedit, et hoc certum indicium veritatis patri suo spirituali postea revelavit, quia quod ore foris accepit, dentibus masticavit, et secundem quod in specie remanet, saporem distinxit. Hec ei per quindecim dies gracia permansit.' $V M Y$, 24.118-19. On this episode, see also briefly above: Chapter 2, p. 127.

$133 V L A, 1.1 .13 .239$. See also: ibid., 1.2.14.240. 
of God' ('semper [...] in Dei servitio robustior \& alacrior'). ${ }^{134}$ Moreover, for a length of time after the event, her saliva tastes 'mellower than the sweetest honey' ('super omnem mellis dulcorem suavius'), sweetened as it is by God's grace. Such episodes of mystical Communion are superior forms of the female respondent's conceptualized online Communion: the saint receives tangible evidence of the rite, even though it occurred in vision space. By comparison, virtual SL Communion can only ever be partial. A user's avatar 'ingests' the wafer and wine through a series of mouse clicks, yet the offline body of the user cannot taste, smell, and touch the sacraments.

Physical traces of the sacraments testify to the medieval woman's authentic experience of the rite. Such evidence contributes to the threatening nature of mystical Communion for the clerical establishment. If such experiences were inferior - or parallel - to 'normal' Communion experiences, then the Church could dismiss them as subordinate to the doctrinally approved rites. After all, to connect with the divine in an orthodox manner, a priest would still be needed. This is the case for modern examples of online rites, as discussed above. However, mystical Communion is clearly a thorny issue for hagiographers, keen to situate saintly protagonists within authorized religious practices, yet dependent on such moments of extraordinary divine intimacy for a construction of a woman as particularly holy. Margaret of Ypres bypasses her confessor, and any male representative of clerical power, when she receives the sacrament from Christ directly. Importantly, however, this only occurs when she is unable to find a priest to serve her. It is a worst-case scenario, not an everyday occurrence. In this episode, it is the confessor Zeger's influence on Margaret, rather than Christ's influence, which is emphasized. ${ }^{135}$

Zeger's spiritual or physical presence is not just educative and corrective, but gives Margaret spiritual solace. He allows her a certain interior knowledge of God's presence. Though the biographer maintains that Margaret does not know the reason she is unable to feel the grace of the Lord this particular day, her confessor's physical absence is underlined. It is clear that Margaret's access to God is mediated by Zeger, and thus the direct nature of her relationship to God is minimized. Her first instinct when in spiritual confusion is to turn to her confessor, and then to seek out another priest. The absence of her confessor, and any adequate clerical alternative, drives Margaret to despair. It is only at this point that she turns to Christ himself. It is noteworthy that she herself does not ask for Christ to bless her with Communion, nor any other form of grace. It is 
Christ's decision to visit her and give her Communion directly; Margaret's behaviour is faultless.

\section{Crucifixion Online}

The SL user interacts directly with God as spirit in virtual worship rites; medieval saints, who may actually see and even touch Christ in the flesh during their visions, interact with God as physicalized man. Nevertheless, products sold on SL Marketplace allow for a kind of virtual imitatio Christi. For L\$298 (c. £0.95), Residents can have their avatar take up the body of Christ on the cross, using the 'Jesus Cross with Animation' (see Fig. 14). As the user's avatar, operated by the offline body, melds with the body of Christ, the offline body of the user implicitly and momentarily melds with Christ's body on the cross too.

The 'Jesus Cross' received a rating of four out of five stars by eight users. With what criteria did reviewers rate this product? Religious efficacy? Aesthetic enjoyment? Innovative programming? It is impossible to know. But its creator, Trigit Amat, is clear in his intention for this product to be used for the stimulation of intense - and authentic - emotions. The 'Cross' is listed with the following description:

This artwork let's you feel like Jesus.

Click the cross and become Jesus.

The symbol of a man on a cross is associated with very strong emotions. These get even wilder, when you experience yourself (or your avatar) on the cross.

Everyone who clicks the cross will find himself/ his avatar in the position of Jesus Christ on the cross.

A wonderful detail is that the titulus over the cross is said to be the relic of the original cross! $!^{136}$

This blurb emphasizes the religious possibilities of the piece: it lets the SL user literally 'become' Jesus. The physical body of the user and his virtual body (avatar) are conflated - 'yourself (or your avatar)', 'himself/ his avatar'. The online manipulation of the avatar's body is a vehicle for the religious experience lodged in the user's offline body. What happens to the body of the avatar directly affects the body of the offline user too. 
Figure 14 Author's Second Life avatar using 'Jesus Cross with Animation' (created by Trigit Amat)

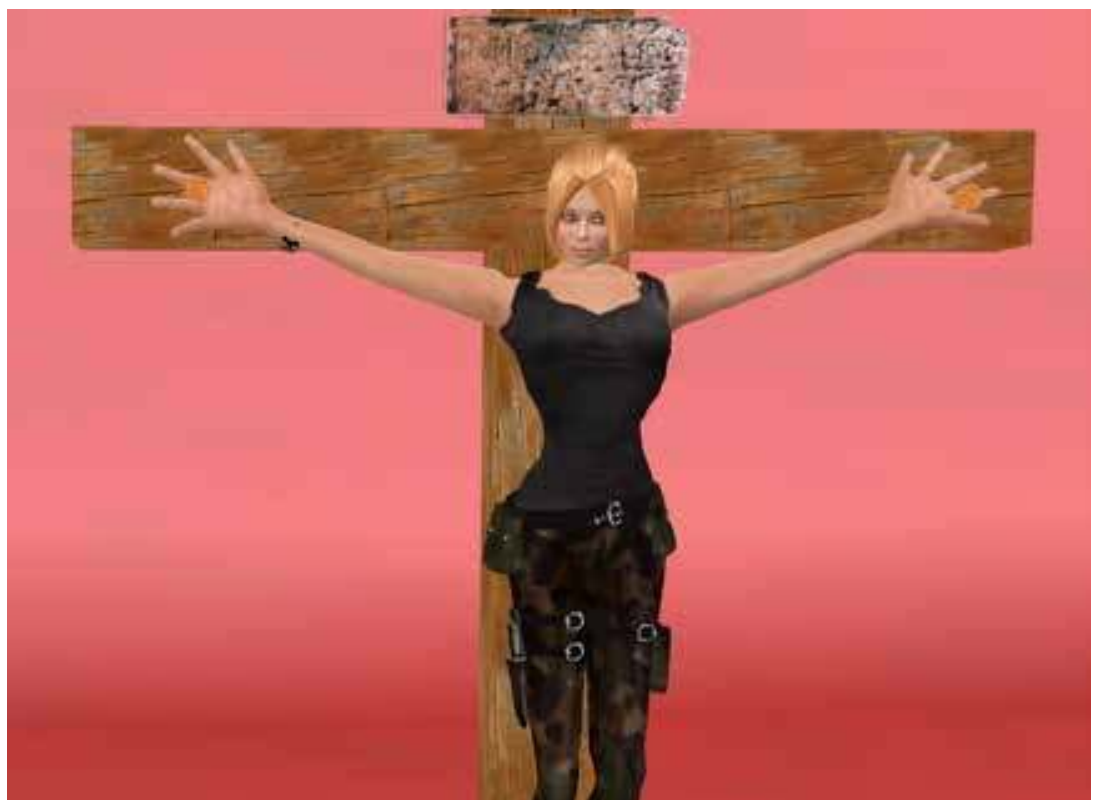

SL crucifixion stirs strong emotions in the offline user, as further elucidated by Amat in an interview in which I probed his motivations in creating the 'Cross'. Initially, the object was conceived as an 'art piece', a reflection on the ways in which religion is deeply ingrained in the human psyche, and an innovative way to harness the power of virtual reality ${ }^{137}$ Most buyers purchase the 'Cross' in the period around Easter. Amat theorizes, thus, that the 'Cross' forms part of Residents' Eastertime celebrations as a meaningful devotional object, despite its original conception as an artistic work. The potent affective-religious resonance of the 'Cross' was certainly not lost on its creator. Details in the 'Cross' description are drawn from his own experiences using the piece. Whilst no longer 'religious in a Christian way today', Amat was 'surprised how strong the feelings of seeing [his] own avatar on the cross were'. Indeed, it felt to him as if he were 'committing a "sacrilege"'. This unexpected religious-affective response signalled that 'something interesting' was going on. The 'Cross' was no longer simply a reflective work of art, but a catalyst for personal religious meditation, even for those who no longer actively practise Christianity. 
Amat was compelled to speak to a priest offline, owing to the intense reaction(s) the 'Cross' provoked both for his atheist friends and himself. The cleric reassured him: 'he said, that he does not feel offended about it and that actually it was done in medieval times'. The virtual crucifixion offered by the SL 'Cross' is a modern iteration of the imitatio Christi enacted by medieval holy women in vision spaces. Juliana of Mont-Cornillon, for instance, desperately desires to experience crucifixion to repay in some part the gift of salvation wrought by Christ's ultimate sacrifice. Direct physical imitation of Christ's Crucifixion is impossible for her, thus she turns to the spiritual world instead:

But since she could not physically die on a cross as she wished, she often stretched herself spiritually, with unbelievably fervent love, on the same cross where Christ had suffered. ${ }^{138}$

(Sed quoniam mortem crucis assequi non poterat corpore, ut optapat; saepius in spiritu in eamdem, in qua Christus passus est, crucem, sese incredibili fervore dilectionis extendebat. $)^{139}$

The repetition of 'c' - 'crucis', 'corpore', 'Christus', 'crucem' - insistently links Christ to his humanity, capable of being crucified because of the Incarnation. The soft sibilance of 'saepius in spiritu' contrasts against the harshness of this repeated consonance, emphasizing the distinction between spiritual and corporeal experiences. Yet, the articulation of 's' sounds in 'Christus passus est' undermines this distinction, with the word 'Christus' capturing the hard 'c' sounds associated with the body in this passage, alongside the softer ' $s$ ' of spiritual terms. In 'Christus', we find authentic divinity and humanity in perfect conjunction, indivisible from one another as each is lexically linked to form the majestic whole of Christ, but also coherent individual sounds.

By embracing 'Christus', Christ, and his suffering meditatively, Juliana has an authentic experience of crucifixion. The cross upon which she spiritually lays herself out is the same one as that touched by the body of Christ. In these parallel acts of crucifixion, one biblical and the other meditative, Juliana takes on Christ's body as he also takes on her physicality, and the two achieve union. Ordinary worshippers could access a similar - though secondary - experience of imitatio Christi, by following a given holy woman, reading her biography and imagining themselves as the 
protagonist. Imagination, though, can be doctrinally troublesome. Whilst a hagiographer, and text, can suggest vehemently a certain meditation or interpretation of events, the contemplative act is individualistic. The scope and content of a believer's imaginings are outside of the direct control of the Church. Vision space, as a projection of contemplation, is also potentially threatening to ecclesiastical controls: in the virtual mystical realm, there is no need for the clergy. However, the content of mystical visions provides useful testimony as to the veracity of doctrine, alongside witnessing the power of God in the world.

\section{Men, Women, and Heterodoxy}

Heresy haunts vision space. In a similar manner, experiences of religion in SL carry the potentiality of heterodoxy, as the space allows a more free-form educative system, with knowledge swapped between users outside of an institutional context. For example, SL was described as a 'safe space' to (re) discover religion by several respondents in my study. Alongside the reality of interpersonal relationships conducted in SL, the spiritual valency of activity in-World is felt to be genuine. Several interviewees in my study emphasized the authenticity of spiritual teaching and ministry in SL, facilitated by online fellowship. One NDC church leader, with a SL congregation that he estimated totalled over 1,700 Christians, testified that he had seen 'hundreds come to Christ as a result of outreach' in SL (male, 46, USA; 2011). Such instances of religious education in SL allow for believers to be inculcated with orthodox doctrine, a complement to offline experiences in church.

Medieval visions, as with online worship, enable the holy woman to develop a deeper understanding of her own faith and the magnificence of God. For example, Juliana of Mont-Cornillon's apprehension of Christian doctrine, garnered in visions, is so great that 'she seemed to have a share in the undiluted truth of our future knowledge. As for all the articles pertaining to the Catholic faith, she had been so fully instructed by him who teaches knowledge to mankind that she had no need to consult masters or books about them. ${ }^{140}$ The vita's author continues that Juliana, receiving such

140 VJCEng, 1.4.20.207. 'ut mera cognitionis futurae veritas, vel ex parte, ipsi contemplanti partes suas agere videretur. De omnibus autem quae ad Catholicam fidem pertinent articulis, illo docente qui docet hominem scientiam, ita ad plenum fuerat edocta; ut non esset quod super his doctores deberet consulere vel Scripturas.' VJC, 1.4.20.451. See also: ibid., 1.2.12-13,44748. Other Liégeoises similarly profit intellectually from divine inspiration: VAS, 1.1.477; VBN, 
clarity of spiritual insight, could never fall victim to heresy or stray from her staunch orthodox faith. Juliana's biographer is necessarily shoring up his text's protagonist against claims of straying too far from ecclesiastical power bases, or authorized clerical doctrine, even though she bypasses clerical authority by getting her teaching directly from God. ${ }^{141}$

Claims as to the superiority of comprehension attained by spiritual visions are also evident in the testimony from male visionaries. The priest from Maagdendaal who experiences mutual ecstatic visions with Ida of Nivelles confesses to an abbess that 'never [numquam] in all his life had he received such [tantam] abundance of divine awareness as he experienced on the occasion of that wondrous vision, in any [neque] writings, any [neque] sermons, any [neque] masses he had celebrated or secret colloquies he had held with God'. ${ }^{42}$ The anaphora of 'neque' in this passage emphasizes the inferiority of mortal means of comprehending God and His teachings. The opposition of 'numquam' and 'tantam' - a complete absence versus an overflowing abundance - highlights the clear hierarchy between the mortal and the spirit world for learning of the divine. This throws into relief the challenge of mystical visions for the ecclesiastical hierarchy. Human knowledge, derived from clerical teaching, can only ever be secondary to knowledge received direct from the divine in vision space. That a holy person, male or female, can access this space and accede to such comprehension indicates the individual's extreme piety - and worthiness as a role model for other believers. The institutional Church relies on holy individuals' experience of vision space to promulgate doctrine and to testify as to the authenticity of the divine. However, what happens in vision space is not controllable by mortal men, and facilitates personal interactions with - and interpretations of - the divine. ${ }^{143}$

The capacity to interact socially in mystical vision space is not exclusive to holy women: the potential for heterodoxy in this arena affects both genders. Along with the priest of Maagdendaal, several other religious men are shown to tap in to the communion of saints in Ida of Nivelles' vita. A priest hears tales of Ida's great holiness, though doubts the honesty of such

2.1.84-86.108-10; VCM, 4.39.657; VIH, 23.68-71.876-77; VILéau, 1.9.109, 2.18.113, 3.21.114; VILov, 3.5.26.188; VLA, 1.1.12.239, 2.2.32.250; VMO, 2.7.71.655, 2.8.76.656, 2.11.98-99.663.

141 VJCEng, p. 207 , n. 113.

142 VINEng, 27d.75. 'quòd numquam in omni vita sua, neque in scripturis neque in sermonibus, neque in Missarum celebratione, neque in secretis soliloquiis cum Domino, tantam diuinę cognitionis abundantiam accepit, quantam in hac visione expertus fuit'. VIN, 27.268.

143 Sudyam, p. 93, p. 95, p. 102. 
testimonies. ${ }^{144}$ After visiting her repeatedly, he remains unconvinced of her piety. A vision of Ida's face during mass, sent to him by God, rectifies this. Thereafter, he visits Ida once more and falls into ecstasy at the sight of her. Ida enters ecstasy immediately, and in a shared vision the pair converse joyfully. In another episode, Christ tells a spiritually weary canon regular to meet with the holy woman in order to find succour. ${ }^{145}$ Appearing in the form of a child to another religious man praying before a crucifix, Christ fobs his worshipper off in favour of first interacting with Ida: "Not just now, son, as I first have to make festivity [Psalms 75.11] in the holy familiarity of love with my friend Ida of Nivelles"'. ${ }^{146}$ The man then witnesses the Christ-child gathering Ida's tears in a basin. Inspired by these vision events which testify to Ida's immense holiness, he journeys to La Ramée to see the holy woman in person, whom he can miraculously recognize from the vision though he has never seen her 'in real life'.

Approaching Ida's window, the man recounts the details of his vision. The passage detailing this encounter features the man's reported and direct speech, yet Ida is entirely silent. The focus is on the man's religious inspiration from seeing Ida in the vision, rather than any direct - or mutual - contact between the two. Christ privileges contact with Ida in this episode, and the text makes no mention of the male religious getting a 'one-on-one' vision of Christ himself. It is also noteworthy that none of the male visionaries in Ida's vita are identified by name. The elision of male identity here is a stark contrast to the foregrounding of Jacques of Vitry and Thomas of Cantimpré in the biography of Marie of Oignies, as dissected in Chapter 3 . Whilst Jacques and Thomas seem to vie with Marie to position themselves 'centre stage', the anonymous men in Ida's text are definitively less important - and less spiritually gifted - than Ida herself.

Whilst men can and do receive visions in the Liégeoise biographies, male visionary experiences seem to be more one-sided than visions shared between holy women. The male religious are gifted with visions of Ida of Nivelles, or visions which direct them to her, but do not meaningfully interact with her in vision space. Despite the capacity to visit with another individual virtually in vision space, no matter what distance separates individuals geographically, male religious typically journey to see Ida 'in real life', with

144 VIN, 26.263-66.

145 Ibid., 16.240.

146 VINEng, 24b.68. 'nunc [...] fili, non liberabo te, quoniam priùs oportet me sancta quadam familiaritate amoris diem festum agere cum amica mea Ida de Niuella'. Emphases in original. VIN, 24.259. 
the exception of the priest of Maagdendaal. Indeed, a priest from Thuin must journey to visit Ida in person to even appreciate that he has been visited by her in a vision, and that the pair shared an intense spiritual experience. ${ }^{147}$ The necessity for a male visionary to see a holy woman in real life in order to have a meaningful interaction is also revealed in Ida of Louvain's vita. An unnamed Premonstratensian canon sees Ida during his ecstasy, and appreciates that they are equally skilled ('aequalis forent meriti') in religious matters. ${ }^{148}$ The experience motivates him to visit her, as the vision allows him to appreciate that she is his only friend. The canon feels such a bond, though he has never met her in real life nor heard about her before his ravishment. It is clear that he sees Ida in a vision, but Ida does not see him. When the pair finally meet, their connection is transformative: 'With such shared insight, it was as if they had lived together their whole lives long and had known one another with identical mutuality. [...] And so, from then on, they were one heart in the Lord. ${ }^{149}$ The basis of their affiliation is their shared love for God and determination to serve Him each day as perfectly as possible. The equivalence of the pair's holiness is undercut in the text, however.

At the end of the canon's short life, his friends are concerned his virtues cannot stack up with the holy woman's, as she has such a longer lifespan..$^{150}$ The canon reassures them that the religious feats he has intensively undertaken in his shorter life are of equal weight to Ida's total sum: weaker and slower, Ida takes longer to reach the same lofty heights. That the man's spirituality needs affirming in such terms underscores the threat of Ida's own holiness. Ida's access to the divine does not threaten her longevity, and she can 'log on' for as long as she lives. Whilst the canon accedes to piety by doing, Ida becomes ever more spiritually worthy by being - something impossible for the canon to achieve, as he is a less able visionary.

\section{Gender-Swapping to Level Up}

An individual of any gender with sufficient stores of spirituality (software) possesses the hardware (body, meditative capacity) to enter the communion of saints. However, women seem to have better software and/or hardware,

147 VIN, 27.268-69.

148 VILov, 1.7.42-43 169.

149 VILovEng, 1.28.43c.35-36. 'Videntes ergo se mutuo, non secus quam si toto vitae suae tempore convixissent, haud dissimili se vicissitudine cognoverunt: [...] Ex tunc igitur \& deinceps extitere cor unum in Domino'. VILov, 1.7.43.169.

150 VILov, 1.7.44 169-70. 
or at least this is how the situation is presented in the vitae of the holy women under discussion here. For a holy woman, almost pure existence as a spiritual avatar and complete enmeshment in the virtual world is thus possible. Holy men as depicted in the Liégeoise corpus, on the other hand, must oscillate between online and offline more frequently, and rely much more on 'meatspace' (life offline, where an individual is locked into the 'meat' of the body) to practise their religion. ${ }^{151}$ In a striking correspondence, studies suggest that male users prefer to present themselves with female avatars in online virtual environments. Feminine bodies are somehow more suitable for, or suited to, internet existence.

Kerstin Radde-Antweiler suggests that more than $60 \%$ of male Residents typically use female avatars. ${ }^{152}$ The source of Radde-Antweiler's figure is unclear. However, this finding is broadly in line with the results of studies of gender-swapping in massively multiplayer online role-playing games (MMORPGs). For example, a 2004 study of the game EverQuest showed that $60 \%$ of the gamers polled $(n=540)$ operated an avatar at odds with their offline gender, though that avatar may not be the user's preferred ('main') character for routine gameplay. ${ }^{153}$ Similarly, a 2008 investigation of the same game found that $57 \%$ of all respondents $(\mathrm{n}=119)$ had engaged in avatarbased gender-swapping. ${ }^{154}$ A note of caution is necessary. As Kevin Linares et al. point out, SL and MMORPGs differ significantly in one respect: the latter are explicitly goal-oriented. ${ }^{55}$ The impact of this difference upon gender swapping is not clear. What's more, not all MMORPGs are alike. Figures for gender-swapping activity in one game may not be generalizable across

151 A parallel investigation of gendered visual superiority in the lives of thirteenth-century holy men and holy women would perhaps produce different results, or at the very least nuance these findings. I speculate that the motif of superior vision is also found in the vitae of the holy men of Liège, perhaps even with holy women presented in these texts as the less gifted seers. The primary rhetorical signification of these lesser gifted seers, taken across the collective corpus, is to throw into stark relief the exceptional visionary aptitude (and thus holiness) of the vitae's subjects. In this, gender is a subsidiary category of difference to holiness. On this and the male corpus, see: 'Beyond the Frame' section of the Introduction above, pp. 52-59.

152 P. 203

153 M.D. Griffiths, Davies, and Chappel, 'Factors', p. 484. In a much-cited earlier study, ‘Stereotype', the researchers reported that only $16 \%$ of Everquest gamers swapped gender. However, as the authors note in 'Factors' (p. 486), the disparity relates to differences in question wording, as participants were asked if they gender-swapped their main character in 'Stereotype', versus any of their characters in 'Factors'. On gender-swapping avatars, see also: Clinnin; D'Anastasio; Davis; Pearce, p. 22-23; Schleiner.

154 Hussain and M.D. Griffiths, p. 50.

155 P. 54 
other games, let alone to non-ludic virtual worlds. More research is needed to discover SL-specific data regarding gender-swapping with avatars.

Veteran MMORPG researcher Nicholas Yee posits that most genderswapping occurs, at least in World of Warcraft, for either practical or aesthetic reasons. ${ }^{156}$ Female avatars are used by gamers as a means 'to be more stylish and to optimize their character'.57 All but two of my study respondents have avatars that match their offline gender. Yee's contention chimes with the response of the male Resident (57, USA, Episcopalian; 2016) who uses a female avatar. He 'simply like[s] the diversity of appearance that a woman has'. His avatar is 'mostly an artistic expression'. My second gender-swapping interviewee, a woman offline (59, USA, Catholic; 2016), underscores that her usage of a male avatar was primarily a pragmatic decision. Heavy demands are typically levied upon female avatars to be fashionable. But with a male avatar, 'you are not under as much pressure to keep having new outfits and new and better mesh bodies and skins and whatnot'. The patriarchal appearance-based economy reigns supreme, even in SL.

As a male avatar, the Resident can get on with the business of living in-World in relative peace: 'I don't care that much about my avatar, his look, what he wears or she wears, I am more interested in the world and exploring it'. In other words, the male-presenting Resident is judged on what she does, rather than how she looks. This Resident's experience is not atypical. The 2008 EverQuest study reported that more female users $(68 \%$; $\mathrm{n}=32)$ than male users $(54 \% ; \mathrm{n}=83)$ gender-swapped avatars. ${ }^{15^{8}}$ The study authors posit that the high rate of women using male avatars is directly linked to the unwanted attention female avatars routinely face from other gamers. ${ }^{159}$ Nevertheless, they maintain that a 'female persona has a number of positive social attributes in a male-oriented environment'. For example, female avatars may have a competitive advantage, receive more help during game-play from other users, and be given useful virtual goods for free, or at a reduced cost. The female body, then, can be an asset and a nuisance by turns. Within the context of medieval visionaries, the (offline) female body seems to provide a 'competitive advantage' in the experience of divinity,

156 'WoW', n.p.

157 Ibid.

158 Hussain and M.D. Griffiths, p. 50.

159 Ibid., p. 52. On this, see also: M.D. Griffiths, Davies, and Chappel, 'Factors', p. 486; 'Stereotype', p. 88; Yee, 'Scrolls', pp. 40-42. Harassment of female users is also endemic in the new realms opened up by Virtual Reality (VR) technology, which is essentially a more immersive version of MMORPG environments. On this, see: Belamire; Lorenz; Shriram and Schwartz; Westervelt; Wong. 
operating as a conduit that is enviably superior to the male body of monkish peers. Yet, the female body is also a liability, subject to the patriarchal machinations of the clergy and the Church. In vision space (the virtual realm), however, the holy woman accedes to a form of spiritual embodiment liberated from the mortal world's (offline) misogynistic codification. She can finally concentrate on her spiritual business.

Nevertheless, a male avatar certainly proves useful for Ida of Louvain. In an ecstatic vision, the holy woman sees herself 'vested as a priest in robes of incalculable dignity' ('Sacerdotalibus vestibus [...] ac ornamentis ulta quam dici possit inæstimabilibus insignitur') ${ }^{160}$ Immediately after perceiving her gender-swapped form, Ida experiences (mystical) Communion. This episode is catalyzed by the holy woman's considerable distress owing to her confessor's 'hurtful words' ('injuriosis verbis'). In fact, Ida is so aggrieved by the confessor's slights that she repeatedly refuses to meet with him, even though he sincerely repents. The vision takes place in the pair's first meeting after the dispute, as Ida stands directly behind the cleric as he celebrates mass. Though the priest may be the focus of her literal gaze, he is utterly irrelevant to Ida's vision and subsequent communication: 'Within the vision, the monk did not so much as play a part, and nor did Ida so much as advert to his being there, whether with her bodily eyes or with her spiritual. Nor did she overhear him, as she usually did, in his reciting of the texts in the Missal. ${ }^{161}$ Doctrine forces Ida to suffer her confessor's presence. He is, at least in theory, the gatekeeper to the Eucharist. Yet her visionary capacity allows her to cut the cleric out of the equation entirely, and give herself the Eucharist directly. With her vision and with her male avatar, Ida demonstrates the fact that she does not rely on her inimical confessor for her spiritual salvation. She can - and does - ignore him, prioritizing her pious worship instead. For the Church hierarchy, this is a threatening prospect indeed.

Ida of Louvain engages in what is termed, in modern parlance, as 'clerical role play' (CRP). In CRP, a Resident uses an avatar dressed in clerical garb to perform, at least superficially, the role of a priest in-World. Two Roman Catholic participants in my study, 'John' (male, 50, Italy; 2016) and 'Matthew' (male, 18-24, USA; 2016), undertake CRP in SL, leading (non-sacramental) services, such as the liturgy, at churches in-World with priestly avatars. Both are emphatically transparent that they are not ordained priests offline, and

16o VILovEng, 3.3.5b.75; VILov, 3.1.5.183.

161 VILovEng, 3.3.5b.75. 'in qua visione præsati monachi nullam omnino habuit, sed nec oculis corporalibus aut mentalibus ejus advertit praesentiam, aut celebrantis officium, un interdum consueverat, auscultavit.' VILov, 3.1.5.183. 
the fact is not hidden in any way from SL congregants. Nevertheless, both have usernames which include an ecclesiastical title. Life circumstances - a much-wanted marriage for John, and severe chronic ill-health for Matthew mean that neither can pursue a clerical path offline. CRP in SL, then, offers these Residents a means to partially fulfil their otherwise unrealizable goal of a clerical career, whilst also helping those in need and spreading the Word. The same can be said for Ida of Louvain's foray into CRP, though her ministry is only self-directed. Respect for the authority of the Vatican was evident in my interviews with both John and Matthew. When asked whether virtual Communion would be acceptable, if provided by a 'real' (i.e. offline) priest's avatar, John defers to the clergy: 'they are rl priests, so they are able to know exactly if they can or not'. Matthew stresses that neither he nor the SL church in which he ministers are 'a replacement for a real church and the real Sacraments'. Nevertheless, they 'are a visible extension of the real Catholic Church in second life'. In this context, he rejects a label of CRP for his activities in-World. He does not 'role play' his faith, nor his dedication to sharing it with others.

Even so, some Residents categorically dismiss CRP as a form of legitimate religious service. For example, another Catholic (female, 48, USA; 2016) interviewee maintains that 'a priest is a sacred role [/] Holy Order [/] [...] the collar is meaningful... the vestments are meaningful'. As such, she hypothesizes that 'a RL priest or monk' would probably eschew clerical garb in SL. Tim Hutchings remarks that such push-back against CRP demonstrates the importance, for some, of 'the continuation of traditional forms of authorisation' even in virtual spaces. ${ }^{162}$ Indeed, the Resident voices a desire for more 'guidance' from the Vatican on the issue, and on the practice of Catholicism more generally in-World. At the moment, she remarks, 'we all kind of wander about here doing our own thing [/] which is fine... but it would be good to know where the boundaries should be'. One Roman Catholic SL archdiocese, at least, has sought offline clerical counsel on CRP. The Archbishop of the SL Lepanto Archdiocese, Stephen Francis Byers, discussed the matter with Bishop Athanasius Schneider, auxiliary bishop of Astana, Kazakhstan. Bishop Schneider, touted as an expert in Canon Law, reasoned that since "no objects are "real"' in SL, CRP by laity is permissible. ${ }^{163}$ Somewhat paradoxically, the presence of priest-avatars in SL is legitimate because they are, in fact, virtual forms that are illegitimate in the eyes of the

162 'Politics', p. 74. Hutchings also details here rejection of CRP as expressed by an Anglican Resident.

163 Byers, n.p. 
Church. None of the Lepanto clerics are ordained offline. For this reason, the Archdiocese is quite clear: 'we cannot give any consultation on personal matters or spiritual guidance. PLEASE proceed to your spiritual director or Priest in real life if this is the case'. Lepanto conserves the traditional hierarchy of the offline Church. However, CRP has the potential to up-end the conventional flow of power, with laity supervising the clergy in spiritual matters.

One Roman Catholic respondent, 'Luke' (male, 55, Australia; 2016), is active in his preferred SL Catholic community. He is also training to be a deacon offline, and 'is practising' what he learns in World. Luke has proposed a number of changes to his church's services, including rectifying errors in the scriptural passages currently provided to worshippers. So far, church leaders have mostly welcomed Luke's input. But, as he says, 'it is really up to the owner of this place [the SL church, i.e. the CRP hierarchy] to consider'. As he does not own the SL church, Luke cannot 'go in guns blazing', as he puts it, regarding doctrinal matters. In Luke's experience, and in Ida of Louvain's visionary CRP discussed above, virtual priests call the shots. As a holy woman, Ida 'owns' mystical vision space, and she dictates what takes place there. However, Ida and the SL church leadership's ability to exercise such power is ultimately dependent on the fully authoritative status of the (offline) Catholic Church. The latter accede to some form of religious authority in World precisely because their activities are dismissed as 'not real' by the Church. Ida's visions, and indeed her visionary capacity, are circumscribed by the diktats of the Church as to legitimately pious worship praxes. The holy woman's CRP is not validated in the vita as a moment of personal spiritual empowerment. ${ }^{164}$ Instead, it is framed as an event which facilitates Ida's reconciliation with her confessor, which thus brings her back under tight clerical supervision.

\section{Agency and Dependence}

Hypothetically all zealously religious holy individuals can access the communion of saints and experience direct contact with God. This would equate to bypassing clerical control in favour of an intimate, individualistic relationship with God. Instead of depending on the Church and its representatives for knowledge of the divine and access to the sacraments, a saint can 'log on' to virtual spiritual space whenever they are so inclined. 
However, medieval hagiographies depict again and again the devotion of their protagonists to regular church attendance, with concomitant clerically authorized Communion, in the 'RL' (real world) outside of visions. For example, we are told that Juliana of Mont-Cornillon longs to go to mass in a real church every day, visiting church more often than is her sisters' custom. ${ }^{165}$ Church attendance is positioned as superior in Juliana's eyes to individual contemplative practice: 'Her spirit could not rest except by compelling her to do one of two things - either attend mass or else devote herself to prayer at that time wherever she could. The first was her fervent desire, the second her consolation. ${ }^{166}$ Despite what we learn in vitae about the supremacy of divine visions for experiencing God, in this passage vision space is clearly of lesser value than attending mass performed by a priest.

Hagiographers must carefully position the holy women they write about as sufficiently unique in their spirituality and devotion, but also nonthreatening to existing patriarchal ecclesiastical structures. Though saints can 'log on' to God whenever they wish, they also conform to traditional Church hierarchies. Access to the virtual realm of the communion of saints is a product of exemplary piety, and also endows the saint with the status of a genuine holy individual. As a marker of holiness, such access may be more aspirational than actual, inasmuch as a saint's ability to enter mystical vision space is a way in which hagiographers can signal the saint's holiness and thereby justify their sacralization. The social and political strictures of the offline world intervene in the saint's visionary experiences, however, forcibly interrupting the spiritual internet connection which would allow the saint to be 'logged on' $24 / 7$.

Analysing the tension between institutional spirituality 'offline' and more personal expressions of medieval spirituality 'online' allows us to discern a conflict evident in digital culture generally. ${ }^{167}$ Internet users tend towards produsage, personalized content and product creation which affirms - consciously or not - membership of a collective, a 'horizontal' network of individuals without an oppressive hierarchical structure. By contrast, traditional content producers, including hardware manufacturers, software developers, and the Church, operate 'vertically'. They wield power from the top down, often leaving users with little choice or power.

165 VJC, 2.2.11.447.

166 VJCEng, 1.2.11.193. 'non requiescente aliter spiritu ejus, unum è duobus facere cogebatur, aut Missae solenniis interesse, aut illo tempore ubi commodius poterat orationi incumbere: \& primum quidem sibi erat in ferventi desiderio, reliquum in solatio'. VJC, 1.2.11.447.

167 On this conflict, see in particular: Le Crosnier, p. 191. 
Both 'horizontal' and 'vertical' planes depend on the other. A user cannot produse without the hardware and software to do so. Yet the commerciality of digital business depends on user uptake and engagement with products, tools, and so on. In a similar manner, medieval vision space ('horizontal'/ heterodox) is dependent on ecclesiastical doctrines ('vertical'/orthodox). ${ }^{68}$ Images and motifs present in vision space - and the very possibility of mystical visions - are dependent on foundational Catholic tenets such as the communion of saints and the capacity of a believer to unite physically and meditatively with God.

With respect to SL, the virtual environment is a free-for-all for produsage ('horizontal'/heterodox). However, in order to access the online space, Residents depend on the offerings of commercial entities offline ('vertical') orthodox), which provide little choice to the average user, namely internet connection and hardware. Furthermore, as Drax observes, experiences in SL still depend on the inherently 'vertical' framework offered by Linden Lab. SL depends for its very lifeblood on the creative interventions Residents make within the virtual world. However, as Drax points out, some of Linden Lab's terms of service could be 'highly problematic when it comes to owning things', particularly for machinima creators. ${ }^{169} \mathrm{He}$ stresses that the company's 'heart is at the right place' when dealing with Residents, and he has not personally encountered issues relating to Linden Lab exercising top-down control over users. Nevertheless, Drax acknowledges that there is no escaping the fact that 'we play on other people's playgrounds' when using SL, and other digital services such as YouTube, Google, and Facebook.

Theoretically, Linden Lab could delete SL at any given time, or censor in-World content. The medieval Church could similarly disavow somatic visionary experiences of the divine as pious phenomena. It would be in neither's interest to pull the plug, as it were, given SL and female visionary experiences are such great money-makers, literally or metaphorically in terms of spiritual capital. Nevertheless, the denial of service is a potentiality, as SL users and holy women operate on 'other people's playgrounds'. By consequence, medieval visionaries and Residents must skilfully negotiate the interdependence of 'horizontal' and 'vertical' powerbases, situating themselves somewhere in between the two poles.

168 McLaughlin uses the terms 'vertical' and 'horizontal' to describe the relationship between an individual and God and the relationship between the individual and other believers respectively (p. 24). I argue the relationship between the believer and God outside of vision space is mediated by the Church, and thus deploy the terminology in a similar - albeit nuanced - manner.

169 N.p. 
As 'logging on' to divine space does not replace more traditional worship forms for medieval holy women, so religious worship online was only one element of the expression of faith for the interviewees in my study. ${ }^{170}$ The vast majority of interviewees (twenty-two) attend church offline, alongside their SL devotional activities. SL is embraced by many Christians as a space for meaningful religious expression and worship. However, SL Christians do not generally envisage their in-World spiritual practice as replacing their offline practice. Nor is SL worship entirely equivalent to offline worship for most Residents. The success of prayer in SL lies in the dependent relationship between avatar and offline individual, with avatars as a means of rendering spiritual and intellectual presence visible. The virtual environment is an evolution of Christian devotional practice, thanks to technological advancements. Nevertheless, traditional - even medieval - worship forms are imitated and mirrored in this brave new virtual world. The virtual intersects with the 'real' in Christian practice in SL, but it does not overwhelm it. As one interviewee remarks: 'my avatar has no heart and soul apart from me' (female, 36, USA, Catholic; 2011).

170 This mirrors the behaviour of internet users more generally. The more individuals use the internet, the more they typically connect with others, either face to face or via telephone: Hogan and Wellman, p. 53 . 


\section{Conclusion: The Living Veronicas of Liège}

\section{Unveiling the Veronicas}

Philip of Clairvaux declares that Elisabeth of Spalbeek is 'an unmistakeably alive and open-hearted Veronica' ('scilicet vivae et apertae Veronicae'). Philip refers to the vernicle here: an image of Christ's face purportedly imprinted upon a cloth belonging to a woman named Veronica. ${ }^{2}$ The moniker 'Veronica' relates to both a mystical divine image and a woman. As such, it offers an interpretive framework with which we can understand all of the holy Liégeoises. Analytic strands explored throughout this book are tied up in (the) Veronica: the power of being looked at and looking back; the transformation of a visual object into living personage and vice versa; the operation of screens (veils, icons) in revealing and concealing divinity; the manner in which a holy woman may merge with Christ and become worthy of veneration in her own right. The Liégeoises, as Veronicas, exist in an oscillation between activity and passivity, shifting constantly - and necessarily - between individualized female subjects and objectified saintly artefacts subordinate to the male-controlled Church.

The earliest account of the Veronica legend is found in the Cura sanitatis Tiberii, a work appended to the apocryphal Gospel of Nicodemus and composed no later than $700 .^{3}$ In this text, the emperor Tiberius sends his official, Volosianus, to Jerusalem in search of Christ, whom he hopes will cure him of terrible illness. Volosianus' mission is initially fruitless, as Christ has been crucified. However, he encounters Veronica, a woman in possession of a painted image of Christ. She herself was healed by Christ, who alleviated her haemorrhagic complaint. This identifies her with an unnamed woman from the New Testament (Matthew 9.20-22; Mark 5.25-34; Luke 8.43-48). After some persuasion on Volosianus' part, Veronica and her icon return to Rome with him. With one glance at the image, Tiberius is cured, which leads directly to his baptism. Later accounts, such as that contained in Jacobus

1 VESEng, 16; VES, 16.373.

2 On the Veronica, see in particular: Belting, pp. 541-44; Hamburger, pp. 316-82; Kuryluk; Montgomery; von Dobschütz, pp. 197-262.

3 On the Cura, see in particular: Gounelle, pp. 232-37. See also similar narratives composed before the ninth century and in the late medieval period respectively: Vindicta Saluatoris, in EA, pp. 448-63; Mors Pilati, in EA, pp. 432-35. 
of Voragine's Legenda aurea (composed c. 1260), follow the contours of the older tale in the main. ${ }^{4}$ One significant shift occurs: the painted image of Christ becomes an imprint of Christ's face left upon Veronica's cloth or veil during a chance meeting, as detailed in Jacobus' work. From the fourteenth century onwards, the location of the story shifts to Calvary, and the story of an anonymous woman wiping Christ's face on his final journey began to circulate widely. Christ's visage was purportedly imprinted upon the woman's veil, which she then brought to Rome for popular veneration. The anonymous woman became 'St. Veronica', conflated with the Veronica (image and individual) from earlier stories, though this has no basis in Scripture.

The Veronica image resonated with thirteenth-century holy women, as shown by the presence of a vernicle (synonym for 'Veronica') in Eve of SaintMartin's cell. ${ }^{5}$ One look at the Veronica causes Juliana of Mont-Cornillon to become overwhelmed with pain at the memory of Christ's Passion and faint. Jacques of Troyes (later known as Urban IV) donated a similar image to his sister in Laon in $1249 \cdot{ }^{6}$ Jacques' appreciation for the Veronica is also shared by his papal predecessors. In 1208, Innocent III inaugurated a procession of the icon from the basilica of Saint-Peter to the hospital of Saint-Spirito, and granted indulgences to all who venerated it. ${ }^{7}$ In 1297, Veronica's veil was translated to the Basilica by Boniface VIII. ${ }^{8}$ This concretized the relic's reputation as an object of supreme religiosity, and expanded its appeal to even more devotees across Europe. Nevertheless, the Veronica retained its especially 'close connection' to female religious expression. ${ }^{9}$ This is demonstrated by the prominence and frequency of the vernicle's display in female religious spaces and in texts intended for women, lay and religious alike. ${ }^{10}$ In the early fourteenth century, for instance, a mural depicting Veronica holding a bust of Christ was inscribed close to the sanctuary in the church of the beguines in Sint-Truiden, Christina Mirabilis' hometown. ${ }^{11}$

4 53.233. See also Gervase of Tilbury's earlier account of this meeting: 3.25.604-07. Gervase's rendition differs in two significant ways: he maintains that the woman's name is Martha, and the image of Christ is a painting, not an impression.

5 VJC, $1.5 \cdot 28.453-54$.

6 VJCEng, p. 216, n. 171; Mulder-Bakker, Anchoresses, pp. 133-34.Jacques is connected to Juliana of Mont-Cornillon in various ways. During his tenure as archdeacon of Liège (1243-1249) Jacques discussed Juliana's vision signalling the need for the institution of the Corpus Christi Feast with her supporter, John of Lausanne: VJC 2.2.7.459.

7 Migne (ed.), 104.cc-cciii.

8 Montgomery, p. 812.

9 Hamburger, p. 372.

10 Ibid., pp. 350-82

11 Ibid., p. 372. 
The popularity of the Veronica for holy women lies, perhaps, in its evocation of a 'faith focused on the incarnate Christ.'. ${ }^{12}$ Whether produced on the road to Calvary or in a chance meeting with Christ, the vernicle's power ultimately lies in its indexicality. It is an acheiropoietos, an image made without human interference or fabrication. It thereby offers a link to Christ-as-man mediated only by its material support, and testifies to God's presence on earth. Some scholars have linked the nature of the Veronica's production to film on the basis of its non-human indexing of human form, offering an immutable trace of presence to the spectator. ${ }^{13} \mathrm{As}$ with the Veronica, 'film receives the imprint of the real'. ${ }^{14}$ The Liégeoises' bodies are similarly imprinted with the reality of God's magnificence and Christ's suffering, and make plain the mechanics of Catholic doctrine. The signification of their bodies, marked in various ways that are often initially difficult to comprehend, becomes intelligible once we read the Liégeoises as Veronicas, images of Christ. When Christ imprints himself upon the holy women's bodies and souls during visions, divinity is rendered visible - and tangible - to onlookers in various ways. As saints, the women index God and His heavenly empire, becoming transformed into vernicle icons themselves.

\section{Lively Relics}

Writing in c. 1216, Gerald of Wales offers his own account of the Veronica legend in the Speculum ecclesiae. ${ }^{15}$ Upon Christ's exit from a temple, a woman called Veronica lifts her tunic and wipes his face, securing an imprint of his visage on the cloth. The resulting image is named after this woman, Gerald maintains. However, he also proffers the following gloss: the term 'Veronica' is a 'play on words, meaning the true icon or the true image' ('vocabulo alludentes, Veronicam dici, quasi veram iconiam, id est, imaginem veram') ${ }^{16}$ It is with this inflection that I deploy the term 'Veronica' for the holy women of Liège: holy individuals who function as 'true icons' of Christ, living relics. The interconnection of text and image in Gerald's anecdote, and in the construction of the 'Veronica' itself, highlights the multimodal quality of medieval media as text and image (reading and 
seeing) interact and overlap. The vitality of the Liégeoises creates another link with the Veronica image, a remarkably lively relic. For example, in his thirteenth-century Chronica majora, Matthew Paris recounts that in 1216 the Veronica resisted being returned to its place at the end of a procession. ${ }^{17}$ As a form of protest, the Veronica re-oriented itself apparently under its own steam ('se per se girabat') so that the Christ-image was upside down.

In several of the Liégeoises' vitae, the protagonists are explicitly shown to take on the form of images or animated relics during their lifetime. Elisabeth of Spalbeek adores a diptych portraying the Crucifixion so much that seemingly she becomes fused with it. During raptures, she clutches the icon so tightly that 'when the tablet itself is drawn or shaken or moved by another person trying, as it were, to rip it out of her hands, she never does let it fall out of her fingers' [grasp], but her own body moves in accord with the movements of the icon'. ${ }^{18}$ Elsewhere in her biography, she is described as being like a statue' ('sicut statua') in pauses in her ecstatic performances, seemingly existing without respiration and without exuding spittle or mucous. ${ }^{19}$ Though immobile as a statue, Elisabeth is still a dynamic presence. Her audience witnesses torrents of blood spilling from her stigmatic wounds which stain her clothing and skin. ${ }^{20}$

Beatrice of Nazareth also turns to images as a means to remember Christ's suffering constantly. She wears a wooden cross continually about her neck, binds an image of the cross to her arm, and sets out a painting of the cross before her whenever she sits down to write. ${ }^{21}$ The plethora of representations ensures that Christ is forever impressed upon her heart ('impressum cordi suo in memoria firmiter retineret'), as she meditatively absorbs - and is absorbed by - the icons..$^{22}$ As the images become imprinted upon Beatrice's body and spirit, she becomes an image herself. Moreover, Christ is shown to imprint his very being into the saint: 'just as soft wax, pressed with a seal, displays the seal's character in itself, so the divine Spirit modeled her soul according to his own image'. ${ }^{23} \mathrm{An}$ identical simile is utilized in Ida of

17 Luard, (ed.), III (1876), 7-8.

18 VESEng, 7.5. 'cum ipsa tabula ab aliquo trahitur aut quasi conamine eam eripiendi concutitur aut movetur, nunquam discohaeret digitis, sed movetur secundum modum tabulae totum corpus'. VES, 7.367-68.

$19 V E S, 5.366$ and 29.378 respectively. Translation from VESEng, 5.6. See also her insensibility: $V E S, 10.369$. For further discussion of stasis, see references in $\mathrm{n} .39$ below.

20 VES, 13.371.

$21 \quad V B N, 1.14 \cdot 70.88$.

22 Ibid., 1.14.70.90.

23 Ibid., 2.18.166.195-97. 'et sicut, impressa sigillo mollis cere materies, illus in se karacterem representat., sic ad ymaginem suam illam effigiatam, diuinus spiritus redderet:, et ad similitudinem 
Nivelles' vita to characterize her relationship with the holy Trinity. ${ }^{24}$ The imprinting of Christ's image upon the holy women parallels the production of the Veronica image, transforming the saints into living acheiropoietoi. At the end of Beatrice's hagiography, the reader is addressed as follows: 'May you firmly imprint on your minds and inscribe on the fleshy tablets of your heart the imitable image of her life which you grieve to have been withdrawn from your eyes. ${ }^{25}$ Contemplation of the holy woman allows a reader to be imprinted with the saintly image, itself a copy of Christ's image. Through a chain of divine indentations, a reader may become a Veronica too.

\section{Bargaining: Agency and Impotence}

As Veronicas, the Liégeoises offer material presence to divinity in the world. Thus they play a crucial role in bolstering Catholics' faith, and thereby accede to certain forms of agency. Though they retain a trace of divine presence, as icons they exist ultimately to be looked through. As image-objects, they represent divinity that is accessed not by looking at the image itself, but looking through the image - a 'window to heaven' - to see the divine presence signified. ${ }^{6}$ Becoming a Veronica entails a process of effacement as much as dynamic presence. In this, the relationship between sanctity and celebrity comes back into focus: 'iconic' is the label with which our most famous celebrities are affixed. ${ }^{27}$ These stars are those who are beloved by the masses, whose special status has been accepted. But this recognition that the 'iconic' star carries within them the real trace of the ' $\mathrm{X}$ factor' comes at a cost. As an 'icon', their subjectivity is evacuated as they are transformed into a cultural symbol, albeit a rich and privileged one. The 'iconic' celebrity represents elements of a culture in which they can no longer participate fully, precisely due to their representational function. This is the 'price of fame', the heavy toll enacted on the stars.

suam decentissime figuratam'. Ibid., 2.18.166.194-96. On the language of 'impression' in the corpus, as akin to photographic process(es), see also above: Chapter 1, pp. 74-75.

24 'quia sicut cera impreßa sigillo, sigilli in se retinet imaginem, sic eius anima'. Emphases in original. VIN, 28.271. See also Ida's habit of holding books so tightly that they leave bruises on her body: ibid., 2.207 .

$25 V B N, 3.17 .274 .343$. 'quatenus imitabilem sue conuersationis ymaginem, quam vestris substractam doletis aspectibus, [...] sic vestris mentibus imprimatis et in tabulis cordis carnalibus tam firmiter inscribatis'. Ibid., 3.17.274.342.

26 Quote from SL Resident, female, 36, USA, Catholic (2011).

27 Maniura, p. 51. 
The religious women of Liège were 'simultaneously central and marginal' to the Church: excluded from the ranks of the clergy, but essential in maintaining the Church's powerbase. ${ }^{28}$ The corpus emphasizes strictly orthodox behaviours, and offers myriad examples with which to combat heresy. Indeed, the hagiographies can be read as responses to the ordinances of Lateran IV (1215), which highlight the specific problems faced by the Church in the thirteenth century. ${ }^{29}$ Again and again, the texts underscore the dangers of heterodoxy and recapitulate the importance of the sacraments of confession and the Eucharist. As Lateran IV mandated annual auricular confession for Christians, it also strengthened the doctrinal status of purgatory, the future destination for those who do not confess sins fully. ${ }^{30}$ Equally, purgatory, envisioned as a set system of post-mortem judgement, was intrinsically anti-heretical, as many of the heterodox cults questioned or outright rejected judgement after death..$^{31}$ Despite their practice of a new form of piety, the Liégeoises remain locked within the framework of medieval Catholicism and are subject to its governing rules.

Dyan Elliott maintains that narratives describing female mystics' intercession for souls in purgatory can be interpreted as 'essential to oiling systems of justice that otherwise might atrophy through excessive rigidity'. ${ }^{2}$ The Church could route acts of mercy, such as the liberation of souls via prayer, through women and thereby not be tainted by any claim of weakness or wavering on core doctrine. Various episodes from the corpus are challenging to understand, such as Christina Mirabilis' bizarre behaviours or Alice of Schaerbeek's glorying acceptance of her leprosy. Yet, the texts themselves do not challenge overwhelmingly Church precepts or the male-controlled system itself. The interpretive challenge of such episodes lies in the ways in which the women make manifest - incarnate - the ramifications of doctrine taken to its full extent.

The Liégeoises' spirituality plays a 'salient, albeit at times covert, role' in buttressing the Church and its ecclesiastical elite. ${ }^{33}$ Nevertheless, the holy women are not passive victims of the clergy, witnessed by their powerful influence in various spheres of activity - social, political, and spiritual. The women cannot function as holy individuals without contact with, and support from, men. For example, they require priests and confessors to

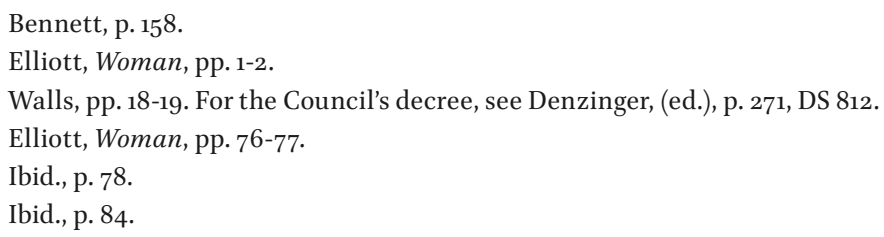


offer them the sacraments and illustrious men to lobby for their protection and welfare. However, such men need the holy women too. As the texts underline frequently, not everyone is able to see God like these women can. Even when men do have mystical visions in the hagiographies, their experiences are qualitatively inferior to the women's divine liaisons. Men need contact with the holy women to magnify their own visual powers. As Veronicas, they bring 'heaven down to earth' for us mortals, and by so doing authenticate Catholic doctrine. ${ }^{34}$ What's more, their powers of prophetic insight allow the laity to avoid eternal damnation or demonic possession and to make practical decisions in their everyday lives. Male hagiographers owe their reputation, at least partially, to the protagonists of their texts. To be sure, Jacques of Vitry et al. can compose texts, preach openly, and offer the sacraments but they cannot offer dramatic examples of God's authenticity and munificence themselves.

Immense piety and mystical aptitude form bargaining chips with which the Liégeoises can negotiate, more or less overtly, with the men around them. In an essay from the late 1980s, Deniz Kandiyoti developed her notion of the 'patriarchal bargain', analysing gender relations in non-Western societies. ${ }^{35}$ Within a patriarchal society, women face a system of oppressive 'concrete constraints. ${ }^{36}$ In response, they develop more or less conscious strategies ('patriarchal bargain[s]') with which to carve out space in a hostile sociocultural environment, coping mechanisms that allow for active and passive resistance ${ }^{37}$ In other words, women learn to 'play the game' of patriarchy. Though the deck is stacked against them - the house always wins, after all - women may experience small triumphs by following skilfully the logic offered by the patriarchal system.

The holy women of Brabant-Liège engage in a series of shifting 'patriarchal bargains' with dominant male-controlled structures, a series of negotiations enabled by leveraging their unique holiness more or less consciously. The Liégeoises uphold Catholic doctrine, defer to the clergy, and do not threaten earthly ecclesiastical structures. In return for this 'good behaviour', they are allowed certain benefits. Mystical vision space offers a chance for direct interaction with the divine and other holy individuals outside of clerical interference. Holy women develop intensely personal relationships with Christ,

35 'Bargaining with Patriarchy'. Bennett also deploys this terminology to discuss the reasons why medieval women married: pp. 148-49.

36 Kandiyoti, p. 275 .

37 Emphases in original. 
in which their own spirituality is perfected. Unions with the heavenly bridegroom replace traditional spousal ties, freeing the women from domination by husbands and sons. By prophecy, they can intervene in earthly politics and help shape the world around them. As mouthpieces of the divine, holy women can also adopt the role of preacher without falling foul of condemnation.

During ecstasies, Elisabeth of Spalbeek becomes a statue, but she is not a mannequin that others can pose as they wish. As her biographer repeatedly notes, her posture cannot be changed at will by others - her signification cannot be manipulated capriciously by her audience. She is like a certain image of wood or stone that lacks feeling and movement and breath, so that no part of her can be touched or moved, not even her little finger, without her entire body being moved [at the same time] ${ }^{\prime}{ }^{8}$ Utilizing Elisabeth as an image or statue of divinity entails accepting all of her: to make use of her, one has to accept the pose she already inhabits. Each night, Elisabeth experiences multiple ecstatic episodes during which she acts out the different stages of the Passion. It is within these episodes that she becomes literally statuesque, interspersing her dramatic retelling of biblical events with moments of fixity which focus the audience's gaze on her precise incarnation of doctrine..$^{39}$ Her biographer underscores the true signification of Elisabeth and her body: she 'images and expresses not only Christ, but Christ Crucified, in his own body, and also the mystical body of Christ, i.e., the Church'. ${ }^{40}$ Elisabeth performs Church doctrine with strict observance, as all her performances are organized according to the canonical Hours and relay scenes central to Catholic faith. However, the precise form her performance takes - the lean of her head or slant of her leg - is decided by Elisabeth with God. In this way, she accedes to a role officially prohibited to women. She becomes a kind of bodily preacher, expounding on Scripture physically. ${ }^{41}$ This is made explicit in the text, as Philip of Clairvaux remarks that her performance of the Passion operates 'as if she were explaining to [onlookers] that gospel message [Matthew 8.20; Luke 9.58]' ('ac si illud evangelicum nobis exponeret'). ${ }^{42}$

38 VESEng, 3.4. 'ut imago quaedam ligni aut lapidis sine sensu et motu et flatu tota rigida perseverat, ita quod de ipsa nihil tangi aut moveri potest, nec etiam minor digitus, quin tota machina moveatur'. VES, 3.364 .

39 On this, see also the discussion of bodily rigidity during episodes of coma-like ectastic stasis above: Chapter 1, pp. 73-77. See also brief references on p. 131, p. 246.

40 VESEng, 30.1. 'non solum Christum et ipsum crucifixum in suo corpore, sed etiam Christi corpus mysticum, id est Ecclesiam, effigiat et exponit'. VES, 30.378 .

41 Simons, Cities, pp. 130-31.

42 VESEng, 10.10; VES, 10.370. 
Visa Immonen and Jussi-Pekka Taavitsainen describe the 'chiastic structure' between a relic and the community which venerates it: the relic's 'existence required an accepting community, but on the other hand, this community and its collective memory was partly formed through the act of recognition'. ${ }^{43}$ A similar dynamic is evident in Elisabeth's life, and in the entire corpus of living Veronicas from Liège. Claude Carozzi maintains that the ultimate destiny of a saint is to become 'a lifeless object, a relic' ('un objet sans vie, une relique'). ${ }^{44}$ This pronouncement erroneously equates relics with passive object-hood. In fact, medieval relics exhibit a 'marked liveliness'. ${ }^{45}$ As such, Elliott's description of the Liégeoises as 'animated relics' is accurate but tautological: exertion of power in the world is central to the mechanics of relics. ${ }^{46}$ Elisabeth's immobility strengthens an interpretation of her as a living relic, as dead saints were understood - and shown - to block the movement of their bones if they so wished. ${ }^{47}$ For example, a saint could stop theft of her relics by working a miracle which rendered them fixed in place. A refusal to produce such a miracle led to the 'participation' of the saint in the act of theft, often due to unhappiness at the level of veneration at the bones' current home.

Traces of such wilfulness are evident elsewhere in the corpus. In Christina Mirabilis' vita, an unknown old woman - likely the saint herself - appears to a priest some twenty-five years after the saint's death. She orders the translation of Christina's relics to a new location as her current tomb is being sorely neglected. Failure to obey will result in unspecified divine punishment, motivating the priest to move the relics immediately to a place beside the altar. ${ }^{48}$ Marie of Oignies' corpse is decidedly stubborn. When the prior of Oignies tries to harvest some of her valuable teeth with great violence, Marie's jaw remains firmly locked in place until the prior offers sufficient prayers. ${ }^{49}$ Marie's transaction with the prior brings to the fore another dynamic element of relics: they act as vectors by which worshippers

43 P. 162.

44 My translation; p. 266. Carozzi refers specifically to the southern French beguine Douceline of Digne (d. 1274), but his comments stand more generally.

45 Hahn, 'Do For Relics', p. 299.

46 Elliott, Woman, p. 71.

47 Hahn, 'Do for Relics', p. 294.

$48 V C M, 5 \cdot 57.660$. I also discuss this episode briefly above, Chapter 1: p. 86.

49 VMOSupp, 3.14.672. See also Lutgard of Aywières' vision of the holy virgin Osanna, who laments that all have forgotten her and that her tomb's inscription has been lost: $V L A, 2.3 \cdot 34.251$. This is framed in the text as a response to a priest's inability to find out the 'owner' of a crypt, but equally shows the everlasting connection of a saint to her bones. 
contact a saint and by which a saint can respond by transmitting God's grace.

Elisabeth's extreme visibility during performances is balanced by an acute disinclination to be seen at other times. She reportedly flees from spectators after returning from ecstasy, and covers herself modestly with a veil during ravishments. ${ }^{50}$ Such a desire to remain hidden from sight is evident in several other vitae, most notably in the life of Marie of Oignes, who decamps to Oignies in order to avoid crowds of visitors..$^{51}$ The motif of modest self-concealment corresponds to the humility topos. It also underscores the fact that the holy woman's exposure is involuntary, and thereby not due to her pride. In return for moments of dynamic public presence, the saint has to be seen to veil herself willingly for most of her life. From another perspective, the rhetoric of concealment and revelation is central to the Liégeoises' leveraging of power. Their visions reveal the authenticity of the divine and Church doctrine. Inherent in the action of rendering the divine visible, however, is the concealment of the divine from those who are insufficiently holy to access it directly.

The holy women act as screens for God in both senses of the term. A screen enables the otherwise ephemeral to be seen, but also separates space, mediating and obfuscating what lies behind it. Veronica's veil, for example, makes plain Christ's visage but denies direct contact with his body. Moreover, according to Gerald of Wales, the vernicle veil is revered in Rome but kept entirely obscured by veils ('nisi per velorum quae ante dependent interpositionem inspicitur'). ${ }^{52}$ Access to an image which already ineluctably forecloses an unmediated apprehension of the divine is highly controlled, if not denied altogether. Such fluctuation between display and concealment also finds parallels in the manner in which medieval reliquaries signify the sacred. ${ }^{53}$ Whilst a reliquary's form may correspond to the relic it supposedly houses - an arm reliquary may contain an arm bone, for example - it rarely displays the bones openly. Instead, the worshipper is invited to gaze partially or meditatively on the relic subsumed within its container, which functions to control the signification of its contents. ${ }^{54}$ As Cynthia Hahn formulates:

$5^{1} \quad V M O, 2.11 .93 .661$. See also: ibid., 2.5.47.649; 2.7.65.654; VJC,1.1.8.446; VLA 1.1.12.239. On Marie's popularity and her transfer to Oignies, see respectively: Chapter 3 generally; and pp. 148-52.

$5^{2} 6.279$.

53 Hahn, 'Do for Relics', pp. 289-9o; 'Objects', p. 10.

54 On the signification of reliquaries' form, see in particular: Hahn, 'Metaphor'; 'Voices'. 
The reliquary works hard to 'represent' the relic as powerful, holy and sacred, part of the larger institution of the Church, at times using biblical metaphor as part of the process of creating meaning. While at the same time the relic is thus made 'fully visible' in its power and associations, it is also unquestionably hidden from view..$^{55}$

From this perspective, vitae serve as reliquaries for the relics (saints) which they display textually.

\section{The Other Women, Glimpsed in the Mirror}

Catherine Brown suggests that, in a typical modernist approach, the medieval era is anachronistically isolated from contemporary concerns. In such colonialist research, the Middle Ages are 'the Other, figured as veiled woman, mystical and enticing'. ${ }^{6}$ As I frame my trans-historical project in terms of the pre-eminent medieval veiled lady, Veronica, I am acutely aware of Brown's pronouncement. I refer to Veronica not to conjure to mind a mystical and unknowable (veiled) subjectivity. Rather, this veiled lady (or perhaps veil-lady) permits greater comprehension of the subjective experiences of the holy women of Brabant-Liège, and the visual processes in which all medieval individuals participated, at least to some extent. As such, I unveil and thereby de-exoticise the medieval 'Other' paradoxically by casting the subjects of my research as veil, screen, and icon.

It is not my intention to conjure the holy women of Brabant-Liège as simplistic proxies for the modern cinema-goer. Nor do I contend that divine visions are identical to modern film, or that spectators in both eras have the same precise experience. The medieval era is not a rigid parallel to our own contemporary moment, a temporal space which maps on to our own exactly and onto which we can glibly project specific modern concerns. Yet the medieval era is not sealed off from the modern period, inert and static in the past. Instead, the Middle Ages are in constant oscillating contact with the modern period. Viewed through the hermeneutical lens of modern film theory, the divine visions of the holy Liégeoises - their form, function, and reception - come into focus as a moment in which the medieval and the modern overlap and intertwine. Within the hard kernel of the scopic act, divine and/or cinematic, we find a bridge between the two periods. 
Metaphorically looking at the Liégeoises by studying their biographies, we stare into a fun-house mirror. These women are not us exactly, the contours of their lives are certainly not perfect reflections of our own. Rather, the reflections we discern are distortions of our own experiences, and our own modes of visuality. However distorting, though, the mirror does not lie. There is an uncanny similarity there. The vision(s) of those 'Other' women are our visions too, however contorted and misshapen they may seem to our modern eyes. Their eyes are our eyes, blurred by the sharp grit of the shifting sands of time.

Veronica's 'real womanhood' is a fiction, much like the idiom of the idealized, and thoroughly fictional, 'real woman' that circulates in contemporary discourse. The 'real woman' is a fiction: there is no singular means to embody womanhood in this life or the next. Modern women are trapped in a socio-cultural text not of our own making, 'books of life' filed alongside the Liégeoise vitae. The patriarchy makes 'living Veronicas' of us all, vital subjects trapped in a game of mirrors, stealing glimpses of a liberating paradise through cracks in the glass. 


\section{Abbreviations}

AASS

BHL

BL

BM

BodL

BNF

BRB

CCHLM

CGI

CRP

EA

FUCCSL

KUWtK

LDS

LSTC

$M K B$

MKBEng

MMORPG

MOS

NDC
Société des Bollandistes, ed., Acta Sanctorum quotquot toto orbe coluntur vel a catholicis scriptoribus celebrantur, 68 vols (Antwerp, Brussels, Paris, Tongerloo: various publishers, 1643-1940; 4th repr. Brussels: Impression Anastaltique Culture et Civilisation, 1965-1971)

Société des Bollandistes, ed., Bibliotheca hagiographica latina antiquae et mediae aetatis, 2 vols (Brussels: Société des Bollandistes, 1898-1901)

British Library

Bibliothèque municipale

Bodleian Library

Bibliothèque nationale de France

Bibliothèque royale de Belgique (also known as Koninklijke Bibliotheek van België)

Société des Bollandistes, ed., Catalogus codicum hagiographicorum bibliothecae regiae Bruxellensis, pars 1: Codices latini membranei, 2 vols (Brussels: Pollenuis, Ceuterick et Lefebure / et de Smet, 1886-1889) computer-generated imagery

clerical role play

von Tischendorf, Constantin, ed., Evangelia apocrypha, adhibitis plurimis codicibus graecis et latinis, maximam partem nunc primum consultis atque ineditorum copia insignibus, (Leipzig: Avenarius et Mendelssohn, 1853) First United Church of Christ and Conference Centre in Second Life Keeping Up with the Kardashians, created by Ryan Seacrest and Eliot Goldberg (prod. by Bunim-Murray Productions and Ryan Seacrest Productions, 2007-present) Church of Jesus Christ of Latter-day Saints (Mormons) Mulder-Bakker, Anneke B., ed., Living Saints of the Thirteenth Century: The Lives of Yvette, Anchoress of Huy, Juliana of Cornillon, Inventor of the Corpus Christi Feast, Margaret the Lame, Anchoress of Magdeburg (Turnhout: Brepols, 2011) Staley, Lynn, ed., The Book of Margery Kempe, TEAMS Middle English Texts (Kalamazoo, MI: Medieval Institute Publications, 1996) Windeatt, Barry, trans., The Book of Margery Kempe (London: Penguin, 1985) massively multiplayer online role-playing game Mulder-Bakker, Anneke B., ed., Mary of Oignies: Mother of Salvation (Turnhout: Brepols, 2006) non-denominational Christian 
NTFS

PPD

PT

$\mathrm{RL}$

$R M G$

SL

SLT

$S M G$

TCCSL

TPP

$T P T$

TWOL

UCC

VAS

VASEng

$V B N$

VCM
Dor, Juliette, Lesley Johnson, and Jocelyn Wogan-Browne, eds., New

Trends in Feminine Spirituality: The Holy Women of Liège and their Impact (Turnhout: Brepols, 1999)

post-Pandoran depression

Pacific Time

online slang for 'real life', i.e. the offline world and one's offline life

L'Estrange, Elizabeth, and Alison More, eds., Representing Medieval

Genders and Sexualities in Europe: Construction, Transformation, and

Subversion, 600-1530 (Farnham, UK: Ashgate, 2011)

Second Life, online virtual environment owned by Linden Lab;

secondlife.com

Second Life Time, the time zone displayed in SL until 2006; equivalent to Pacific Time

Cawley, Martinus, trans., Send Me God: The Lives of Ida the Compassionate of Nivelles, Nun of La Ramée, Arnulf, Lay Brother of Villers, and Abundus,

Monk of Villers (Turnhout: Brepols, 2003)

Newman, Barbara, ed., Thomas of Cantimpré: The Collected Saints' Lives;

Abbot John of Cantimpré, Christina the Astonishing, Margaret of Ypres, and

Lutgard of Aywières (Turnhout: Brepols, 2008)

Etienne of Bourbon, Tractatus de diversis materiis praedicabilibus:

Prologus, Prima pars, De dono timoris, ed. by Jacques Berlioz and Jean-

Luc Eichenlaub, Corpus Christianorum Continuatio Mediaevalis 124

(Turnhout: Brepols, 2002)

Etienne of Bourbon, Tractatus de diversis materiis praedicabilibus:

Tertia pars, ed. by Jacques Berlioz, Corpus Christianorum Continuatio

Mediaevalis 124B (Turnhout: Brepols, 2006)

Brown, Jennifer N., Three Women of Liège: A Critical Edition of and

Commentary on the Middle English Lives of Elizabeth of Spalbeek, Christina

Mirabilis, and Marie d'Oignies (Turnhout: Brepols, 2008)

United Church of Christ

Arnulf II of Ghistelles (?), De B. Aleyde Scharembekana, sanctimoniali

Ordinis Cisterciensis, Camerae iuxta Bruxellam, ed. by Godfrey Henschen, in AASS, June II (11) (1688; repr. 1969), 477-83

Arnulf II of Ghistelles (?), Life of St Alice of Schaerbeek, trans. by Martinus Cawley (Lafayette, OR: Our Lady of Gaudalupe Abbey, 2000)

The Life of Beatrice of Nazareth: 1200-1268, ed. and trans. by Roger de Ganck (Kalamazoo, MI: Cistercian Publications, 1991)

Thomas of Cantimpré, De S. Christina Mirabili virg. apud Trudonopoli in

Belgio, ed. by Jean Pien, in AASS, July V (24) (1727 (repr. 1969)), 650-6o 
VCMEng Thomas of Cantimpré, The Life of Christina the Astonishing, in TCCSL, pp. 126-57

VES

VESEng

VIH

VIHEng

VILéau

VILéauEng

VILov

VILovEng

VIN

VINApp

VINEng

VJC

VJCEng

VLA

VLAEng

VMO

VMOEng

Philip of Clairvaux, Vita Elizabeth sanctimonialis in Erkenrode, Ordinis Cisterciensis, Leodiensis dioecesis, in CCHLM, I, 362-78

Philip of Clairvaux, Life of Holy Innocent Elisabeth in Herkenrode of the Cistercian Order in the Diocese of Liège, trans. by Edward Vodoklys and Joanna E. Ziegler (unpublished MS Word document: last modified 2003). NB As this document has unstable pagination, all references relate to the translators' numbering of chapters and subsections (respectively). Hugh of Floreffe, De B. Ivetta, sive Iutta, vidua reclusa, Hvi in Belgio, ed. by Godfrey Henschen, in AASS, January I (13) (1643 (repr. 1965)), 863-87 Hugh of Floreffe, The Life of Yvette, Anchoress of Huy, trans. by Jo Ann McNamara, in LSTC, pp. 71-141

De. B. Ida Lewensi virgine, Ordinis Cisterciensis Rameyae in Brabantia Belgica, ed. by Remy de Buck, in AASS, October XIII (29) (1869 (repr. 1970)), 107-24 Ida the Gentle of Léau: Cistercian Nun of La Ramée, trans. by Martinus Cawley (Lafayette, OR: Our Lady of Gaudalupe Abbey, 1998) De vener. Ida Lovaniensi, Ord. Cisterc. in Brabantia prope Mechliniam, ed. by Daniel Papebroeck, in AASS, April II (13) (1675 (repr. 1968)), 157-89 The Life of Ida of Louvain, trans. by Martinus Cawley (Lafayette, OR: Our Lady of Gaudalupe Abbey, 200o) Goswin of Bossut, Vita Beatae Idae de Niuella Sanctimonialis in Monasterio de Rameya, in Quinque prudentes Virgines, ed. by Chrysostomos Henriquez (Antwerp: Joannem Cnobbaert, 1630), pp. 199-300 Goswin of Bossut, De beata Ida de Rameia virgine, in CCHLM, II, 222-26 Goswin of Bossut, The Life of Ida the Compassionate of Nivelles, in SMG, pp. 28-99

De B. Iulianae virgine, priorissa Montis-Cornelii apud Leodium, promotrice Festi Corpus Christi, ed. by Godfrey Henschen, in AASS, April I (5) (1675 (repr. 1968)), 443-77

The Life of Juliana of Cornillon, trans. by Barara Newman, in LSTC, pp. 181-302 Thomas of Cantimpré, De S. Lutgarde virgine, sanctimoniali Ordinis Cisterciensis, Aquiriae in Brabantia, ed. by Godfrey Henschen, in Acta Sanctorum, June III (16) (1701 (repr. 1969)), 234-63 Thomas of Cantimpré, The Life of Lutgard of Aywières, in TCCSL, pp. 211-96 Jacques of Vitry, De B. Maria Oigniacensi in Namurcensi Belgii dioecesi, ed. by Daniel Papebroeck, in AASS, June IV (23) (1707 (repr. 1969)), 636-66 Jacques of Vitry, The Life of Mary of Oignies, trans. by Margot H. King, in MOS, pp. 33-128 
VMOME Jacques of Vitry, 'The Middle English Life of Marie d'Oignies', in TWOL, pp. 85-190

VMOOL Goswin of Bossut, Office liturgique neumé de la bienheureuse Marie d'Oignies à l'abbaye de Villers au XIIIe siècle, ed. by Daniel Misonne, in Album J. Balon: Hommage à Monsieur Joseph Balon (Namur: Les Anciens Établissements Godenne, 1968), pp. 181-89 (repr. in Revue bénédictine, 111 (2001), 267-73)

VMOOLEng Goswin of Bossut, The Liturgical Office of Mary of Oignies, trans. by Hugh Feiss, in MOS, pp. 185-96

VMOSupp Thomas of Cantimpré, Supplementum [to VMO], ed. by Daniel Papebroeck, in AASS, June IV (23) (1707 (repr. 1969)), 666-77

VMOSuppEng Thomas of Cantimpré, Supplement to James of Vitry's Life of Mary of Oignies, trans. by Hugh Feiss, in MOS, pp. 137-65

VMY Thomas of Cantimpré, Vita Margarete de Ypris, ed. by G.G. Meerseman, in G.G. Meerseman, 'Les frères prêcheurs et le mouvement dévot en Flandres au XIIIe siècle', Archivum fratrum praedicatorum, 18 (1948), 69-130 (pp. 106-30)

VMYEng Thomas of Cantimpré, The Life of Margaret of Ypres, in TCCSL, pp. 163-206 


\section{Bibliography}

\section{Manuscripts}

Augustine, Confessions, Chicago, Newberry Library, MS 12, vol. 7.

Book List, London, BL, MS Sloane 3548, fol. $158^{\mathrm{r}}$.

Collection of Latin Hagiographies, Trier, Stadtbibliothek, MS 1179.

Collection of Texts on Astronomy, Optics, Astrology, and Stones from a Merton College Manuscript, London, BL, MS Harley 80.

Goswin of Bossut, 'Prologue A to Ida of Nivelles' Vita', Brussels, BRB, MSS 8609-8620, fols. $146^{\mathrm{r}}-178^{\mathrm{v}}$.

—, 'Prologue B to Ida of Nivelles' Vita', Brussels, BRB, MSS 8895-8896, fols. ${ }^{\mathrm{r}}-35^{\mathrm{v}}$.

Jacques of Vitry, De vita B. Mariae Ogniacensis libriduo, Oxford, St John's College, MS 182 (C8.55), fols. 1- $68^{\mathrm{v}}$.

—, Seint Mary of Oegines, Oxford, BodL, MS Douce 114, fols. $26^{\mathrm{v}}-76^{\mathrm{v}}$.

—, Vita Mariae Oigniacensis, London, BL, MS Harley 4725, fols. 156-204.

—, Vita Mariae Oigniacensis, Oxford, BodL, MS Bodley 240 (SC 2469), fols. 475-8o.

Margery Kempe, The Book of Margery Kempe, London, BL, MS Add. 61823.

'Passio', Paris, BNF, MS lat. 16482, fols. $136^{\mathrm{r}}-141^{\mathrm{v}}$.

Passio S. Margarete (cum aliquot delineationibus), Munich, Bayerische Staatsbibliothek, MS Clm. 1133, fols. 63-100, urn:nbn:de:bvb:12-bsbooo65187-3.

Sacramentarium Sancti Petri Gamundiensis (known as Hornbach Sacramentary), Zentralbiblothek, Solothurn, Switzerland, MS U1.

Sint-Truiden Abbey Library Catalogue, Brussels, Bibliothèque des Bollandistes, MS 98 .

Vita Aleydis de Scarembeka, in Hagiologium Brabantinorum, Vienna, Österreichische Nationalbibliothek, MS 12706-1207, fols. 248-252 $2^{v}$ http://data.onb.ac.at/rec/ALooo93622 [accessed 5 April 2017]

Vita Simonis Alnensis, Brussels, BRB, MS 8965-66, fols. $209^{\mathrm{r}}-223^{\mathrm{v}}$.

\section{Pre-modern Primary Sources}

Aelred of Rivaulx, De institutione inclusarum, ed. by C. H. Talbot, in Aelredi Rievallensis Opera Omnia, 7 vols (Turnhout: Brepols, 1971-2017), I, pp. 637-82.

Arnold of Liège, Alphabetum narrationum, ed. by Colette Ribaucourt and Elisa Brilli, Corpus Christianorum Continuatio Mediaevalis 16o (Turnhout: Brepols, 2015).

Arnulf II of Ghistelles (?), De B. Aleyde Scharembekana, sanctimoniali Ordinis Cisterciensis, Camerae iuxta Bruxellam, ed. by Godfrey Henschen, in AASS, June II (11) (1688; repr. 1969), 477-83.

—, Life of St Alice of Schaerbeek, trans. by Martinus Cawley (Lafayette, OR: Our Lady of Gaudalupe Abbey, 2000).

Banks, Mary Macleod, ed., An Alphabet of Tales: An English 15th Century Translation of the 'Alphabetum Narrationum' of Étienne de Besançon, from Additional Ms. 25,719 of the British Museum. 2 vols, Early English Texts Society 126-27 (London: Kegan Paul, Trench, Trübner \& Co., 1904-1905). 
Bastida, Rebeca Sanmartín, and María Luengo Balbás, eds., Las Revelaciones de María de Santo Domingo (1480/86-1524), Papers of the Medieval Hispanic Research Seminar, 74 (London: Queen Mary, University of London, 2014).

de Beaulieu, Marie-Anne Polo, ed., La 'Scala coeli'de Jean Gobi (Paris: Centre National de la Recherche Scientifique, 1991).

Boyer, Christine, ed., Humberti de Romanis: De dono timoris (Turnhout: Brepols, 2008).

Bridges, John Henry, ed., The 'Opus majus' of Roger Bacon, 3 vols (Frankfurt: Minerva-Verlag, 1964).

Brother Tristram, SSF, and Simon Kershaw, eds., Exciting Holiness: Collects and Readings for the Festivals and Lesser Festivals of the Calendars of the Church of England, the Church of Ireland, the Scottish Episcopal Church, and the Church in Wales. 3rd edn (Norwich: Canterbury Press, 1997 (repr. 2007)).

Brown, Jennifer N., ed., Three Women of Liège: A Critical Edition of and Commentary on the Middle English Lives of Elizabeth of Spalbeek, Christina Mirabilis, and Marie d'Oignies (Turnhout: Brepols, 2008).

Caesarius of Heisterbach, Dialogus miraculorum, ed. by Joseph Strange, 2 vols (Cologne: Heberle, 1851).

Cawley, Martinus, trans., Send Me God: The Lives of Ida the Compassionate of Nivelles, Nun ofLa Ramée, Arnulf, Lay Brother of Villers, and Abundus, Monk of Villers (Turnhout: Brepols, 2003).

Cura sanitatis Tiberii, ed. by Ernst von Dobschütz, in Ernst von Dobschütz, Christusbilder: Untersuchungen zur christlichen Legende (Leipzig: Hinrichs'suche, 1899), pp. 157-203.

Curley, Michael J., ed. and trans., Saint Patrick's Purgatory: A Poem by Marie de France, Medieval and Renaissance Texts and Studies 94 (Binghampton, NY: Center for Medieval and Early Renaissance Studies, SUNY, 1990).

De B. Ida Lewensi virgine, Ordinis Cisterciensis Rameyae in Brabantia Belgica, ed. by Remy de Buck, in AASS, October XIII (29) (1869 (repr. 1970)), 107-24.

De B. Iulianae virgine, priorissa Montis-Cornelii apud Leodium, promotrice Festi Corpus Christi, ed. by Godfrey Henschen, in AASS, April I (5) (1675 (repr. 1968)), 443-77.

De venerabili Catharina sanctimoniali Ordinis Cisterciensis, Parc in Brabantia, ed. by Godfrey Henschen, in AASS, May I (4) (1679 (repr. 1968)), 532-34.

Devener. Ida Lovaniensi, Ord. Cisterc. in Brabantia prope Mechliniam, ed. by Daniel Papebroeck, in AASS, April II (13) (1675 (repr. 1968)), 157-89.

Denzinger, Heinrich, ed., Enchiridion symbolorum definitionum et declarationum de rebus fidei et morum: Compendium ofCreeds, Definitions, and Declarations on Matters of Faith and Morals, rev. and enlarged by Peter Hünermann, trans. by Robert Fastiggi and Anne Englund Nash, 43rd edn (San Francisco, CA: Ignatius Press, 2012).

Drioux, Thomas, Charles René Billuart, Franciscus Sylvius, and Jean Nicolai, eds., Summa theologica S. Thomce Aquinatis, 8 vols (Paris: Vivès, 1856-1868), VI (1859).

Etienne of Bourbon, Tractatus de diversis materiis praedicabilibus: Prologus, Prima pars, De dono timoris, ed. by Jacques Berlioz and Jean-Luc Eichenlaub, Corpus Christianorum Continuatio Mediaevalis 124 (Turnhout: Brepols, 2002).

-, Tractatus de diversis materiis praedicabilibus. Tertia pars, ed. by Jacques Berlioz, Corpus Christianorum Continuatio Mediaevalis 124B (Turnhout: Brepols, 2006).

Fredericq, Paul, ed., Corpus documentorum Inquisitionis haereticae pravitatis Neerlandicae, 5 vols (Ghent: Vuylsteke, 1889-19o6).

Gerald of Wales, Speculum ecclesiae, in Giraldi Cambrensis Opera, ed. by John Sherren Brewer, James Francis Dimock and George Frederic Warner, 8 vols (London: Longman, 1861-1893), IV (1873), 3-354. 
Gervase of Tilbury, Otia Imperialia: Recreation for an Emperor, ed. and trans. by S. E. Banks and J. W. Binns (Oxford: Oxford University Press, 2002).

Goswin of Bossut, De B. Arnulfo monacho Ordinis Cisterc. Villarii in Brabantia, ed. by Daniel Papebroeck, in AASS, June V (30) (1707 (repr. 1969)), pp. 6o8-31.

-, De beata Ida de Rameia virgine, in CCHLM, II, 222-26.

-, The Life of Arnulf, Lay Brother of Villers, in SMG, pp. 129-198.

—, The Life of Ida the Compassionate of Nivelles, in SMG, pp. 28-99.

—, The Liturgical Office of Mary of Oignies, trans. by Hugh Feiss, in MOS, pp. 185-96.

—, Office liturgique neumé de la bienheureuse Marie d'Oignies à l'abbaye de Villers au XIIIe siècle, ed. by Daniel Misonne, in Album J. Balon: Hommage à Monsieur Joseph Balon (Namur: Les Anciens Établissements Godenne, 1968), pp. 181-89 (repr. in Revue bénédictine, 111 (2001), 267-73).

—, Vita Beatae Idae de Niuella Sanctimonialis in Monasterio de Rameya, in Quinque prudentes virgines, ed. by Chrysostomos Henriquez (Antwerp: Joannem Cnobbaert, 1630), pp. 199-300.

Grant, Edward, ed., A Source Book in Medieval Science (Cambridge, MA: Harvard University Press, 1974).

Grosseteste, Robert, 'De lineis, angulis et figuris', in Die Philosophischen Werke des Robert Grosseteste, Bischofs von Lincoln, ed. by Ludwig Baur (Münster: Aschendorff, 1917), pp. 59-65.

Guillaume of Nangis, Gesta Philippi regis Franciae, filii sanctae memoriae regis Ludovici, ed. by Pierre-Claude-François Daunou and Joseph Naudet, in Recueil des historiens des Gaules et de la France, 22 vols; n.s. 24 vols (Paris: Imprimerie royale, 1738-1865; n.s. 1869-1904), n.s., XX, 466-539.

Hinnebusch, John Frederick, ed., The 'Historia occidentalis' of Jacques de Vitry (Fribourg: University Press, 1972).

Hugh of Floreffe, De B. Ivetta, sive Iutta, vidua reclusa, Hvi in Belgio, ed. by Godfrey Henschen, in AASS, January I (13) (1643 (repr. 1965)), 863-87.

-, The Life of Yvette, Anchoress of Huy, trans. by Jo Ann McNamara, in LSTC, pp. 71-141.

Huygens, R.B.C., ed., Lettres de Jacques de Vitry, 1160/1170-1240, évêque de Saint-Jean d'Acre (Leiden: Brill, 1960).

Ida the Gentle of Léau: Cistercian Nun of La Ramée, trans. by Martinus Cawley (Lafayette, OR: Our Lady of Gaudalupe Abbey, 1998).

Jacobus of Voragine, Legenda aurea vulgo Historia lombardica dicta, ed. by Johann Georg Theodor Grässe, 2 edn (Leipzig: impensis librariae Arnoldianae, 1850).

Jacques of Vitry, De B. Maria Oigniacensi in Namurcensi Belgii dioecesi, ed. by Daniel Papebroeck, in AASS, June IV (23) (1707 (repr. 1969)), 636-66.

—, The Life of Mary of Oignies, trans. by Margot H. King, in MOS, pp. 33-128.

—, 'The Middle English Life of Marie d'Oignies', in TWOL, pp. 85-190.

Johannes of Magdeburg, Die Vita der Margareta contracta, einer Magdeburger Rekluse des 13. Jahrhunderts (Leipzig: Benno Verlag, 1992).

-, The Life of Margaret the Lame, Anchoress of Magdeburg, in LSTC (Turnhout: Brepols, 2011), pp. 303-96.

John of Caulibus (?), Meditaciones vite Christi olim S. Bonaventurae attributae, ed. by C. Mary Stallings-Taney, Corpus Christianorum Continuatio Mediaevalis 153 (Turnhout: Brepols, 1997).

-, Meditations on the Life of Christ, ed. and trans. by Francis X. Taney, Anne Miller, and C. Mary Stallings-Taney (Asheville, NC: Pegasus Press, 2000).

Lemay, Helen Rodnite, ed. and trans., Women's Secrets: A Translation of Pseudo-Albertus Magnus's 'De secretis mulierum'with Commentaries (Albany: State University of New York Press, 1992). 
The Life of Beatrice of Nazareth: 1200-1268, ed. and trans. by Roger de Ganck (Kalamazoo, MI: Cistercian Publications, 1991).

The Life of Ida of Louvain, trans. by Martinus Cawley (Lafayette, OR: Our Lady of Gaudalupe Abbey, 2000).

The Life of Juliana of Cornillon, trans. by Barbara Newman, in LSTC, pp. 181-302.

Lindberg, David C., ed. and trans., Roger Bacon and the Origins of Perspectiva in the Middle Ages: A Critical Edition and English Translation of Bacon's 'Perspectiva' with Introduction and Notes (Oxford: Oxford University Press, 1996).

Luard, Henry Richards, ed., Matthæi Parisiensis, monachi Sancti Albani, Chronica majora, 7 vols (London: Her Majesty's Stationery Office, 1872-1884).

Migne, J.-P., ed., Gesta Innocenti Papae III, in Patrologia Latina, 217 vols (Paris: Migne, 1844-1855), CCXIV (1855), cols. xvii-ccxxviii.

Monumenta Germaniae Historica, inde ab anno Christi quingentesimo usque ad annum millesimum et quingentesimum Scriptores (in folio), 39 vols (Hannover: Impensis bibliopolii Hahniani, 1826-2009).

Mors Pilati, in EA, pp. 432-35.

Muessig, Carolyn, ed. and trans., The Faces of Women in the Sermons ofJacques de Vitry (Toronto: Peregrina, 1999).

Mulder-Bakker, Anneke B., ed., Living Saints of the Thirteenth Century: The Lives of Yvette, Anchoress of Huy, Juliana of Cornillon, Inventor of the Corpus Christi Feast, Margaret the Lame, Anchoress of Magdeburg (Turnhout: Brepols, 2011).

—, ed., Mary of Oignies: Mother of Salvation (Turnhout: Brepols, 2006).

Newman, Barbara, ed., Thomas of Cantimpré: The Collected Saints'Lives; Abbot John of Cantimpré, Christina the Astonishing, Margaret of Ypres, and Lutgard of Aywières (Turnhout: Brepols, 2008).

Papebroeck, Daniel, Commentarius praevius, in AASS, June IV (23) (1707 (repr. 1969)), 630-36.

Philip of Clairvaux, Life of Holy Innocent Elisabeth in Herkenrode of the Cistercian Order in the Diocese of Liège, trans. by Edward Vodoklys and Joanna E. Ziegler (unpublished MS Word document: last modified 2003).

-, Vita Elizabeth sanctimonialis in Erkenrode, Ordinis Cisterciensis, Leodiensis dioecesis, in CCHLM, I, 362-78.

Philippine of Porcellet, La Vie de Sainte Douceline:fondatrice des béguines de Marseille, composée au treizième siècle en langue provençale, ed. and trans. by J.-H. Albanés (Marseille: Etienne Camoin, 1879).

Porete, Marguerite, Le Mirouer des simples ames, ed. by Romana Guarnieri (Brepols: Turnhout, 1986).

Pseudo-Albertus Magnus, De secretis mulierum (Amsterdam: Iodocum Ianssonium, 1655).

Quetif, Jacques and Jacques Echard, eds., Scriptores ordinis praedicatorum, 2 vols (Paris: J.B.Christoper Ballard, Nicolas Simart, 1717-1721), I.

Risner, Friedrich, ed., Opticae thesaurus Alhazeni Arabis libri septem (Basel: Per Episcopios, 1572).

Société des Bollandistes, ed., Acta Sanctorum quotquot toto orbe colunturvel a catholicis scriptoribus celebrantur, 68 vols (Antwerp, Brussels, Paris, Tongerloo: various publishers, 1643-1940; 4th repr. Brussels: Impression Anastaltique Culture et Civilisation, 1965-1971).

—, ed., Bibliotheca hagiographica latina antiquae et mediae aetatis, 2 vols (Brussels: Société des Bollandistes, 1898-1901).

—, ed., Catalogus codicum hagiographicorum bibliothecae regiae Bruxellensis, pars 1: Codices latini membranei, 2 vols (Brussels: Pollenuis, Ceuterick et Lefebure/et de Smet, 1886-1889). 
Staley, Lynn, ed., The Book of Margery Kempe, TEAMS Middle English Texts (Kalamazoo, MI: Medieval Institute Publications, 1996).

Thomas of Cantimpré, Bonum universale de apibus, ed. by Gregorious Colvernius (Douai: Balthazar Bellère, 1628).

—, De S. Christina Mirabili virg. apud Trudonopoli in Belgio, ed. by Jean Pien, in AASS, July V (24) (1727 (repr. 1969)), 650-60.

—, De S. Lutgarde virgine, sanctimoniali Ordinis Cisterciensis, Aquiriae in Brabantia, ed. by Godfrey Henschen, in AASS, June III (16) (1701 (repr. 1969)), pp. 234-63.

-, The Life of Christina the Astonishing, in TCCSL, pp. 126-57.

—, The Life of Lutgard of Aywières, in TCCSL, pp. 211-96.

—, The Life of Margaret of Ypres, in TCCSL, pp. 163-206.

—, Supplement to James of Vitry's Life of Mary of Oignies, trans. by Hugh Feiss, in MOS, pp. 137-65.

—, Supplementum [to VMO], ed. by Daniel Papebroeck, in AASS, June IV (23) (1707 (repr. 1969)), 666-77.

—, Vita Margarete de Ypris, ed. by G.G. Meerseman, in G.G. Meerseman, 'Les frères prêcheurs et le mouvement dévot en Flandres au XIIIe siècle', Archivum fratrum praedicatorum, 18 (1948), 69-130 (pp. 106-30).

von Tischendorf, Constantin, ed., Evangelia apocrypha, adhibitis plurimis codicibus graecis et latinis, maximam partem nunc primum consultis atque ineditorum copia insignibus (Leipzig: Avenarius et Mendelssohn, 1853).

Trithemius, Johannes, Liber de scriptoribus ecclesiasticus, in Bibliotheca ecclesiastica in qua continentur de scriptoribus ecclesiasticus libri plurimonum, ed. by Johann Albert Fabricius (Hamburg: Christian Leibezeit, Theodor Christopher Felginer, 1718), 1-231 (each entry in vol. paginated separately).

Vincent of Beauvais, Speculum historiale, ed. by Benedictini collegii Vedastini (Douai: Balthazar Bellère, 1624) (= Speculum maius, 4 vols, IV).

Vindicta Saluatoris, in EA, pp. 448-63.

Vitae B. Odiliae vidua Leodiensis libri duo priores, ed. by Carolus de Smedt, Iosephus de Backer, Fransciscus van Ortroy, Iosephus van den Gheyn, Hippolyte Delehaye, and Albertus Poncelet, in Analecta Bollandiana, 13 (1884), 197-287.

Vitae Odiliae liber III, de triumpho S. Lamberti in Steppes, ed. by I. Heller, in Monumenta Germaniae Historica, inde ab anno Christi quingentesimo usque ad annum millesimum et quingentesimum Scriptores (in folio), 39 vols (Hannover: Impensis bibliopolii Hahniani, 1826-2009), XXV (1880), 169-91.

Windeatt, Barry, trans., The Book of Margery Kempe (London: Penguin, 1985).

\section{Secondary Sources}

Abad-Santos, Alex, 'We Don't Treat Kim Kardashian Like a Person. Her Robbery Exposed That.', Vox, (7 October 2016), http://www.vox.com/culture/2016/10/7/13186218/kardashian-robberyconspiracy-backlash [accessed 30 March 2017].

Adams, Douglas, The Ultimate Hitchhiker's Guide to the Galaxy (New York: Del Rey Books, 2010). Kindle edition.

Akbari, Suzanne Conklin, Seeing Through the Veil:Optical Theory and Medieval Allegory (Toronto: University of Toronto Press, 2004). 
Allen, Amanda K., 'Social Networking, Participatory Culture and the Fandom World of Harry Potter', in Medieval Afterlives in Contemporary Culture, ed. by Gail Ashton (London: Bloomsbury Academic, 2015), pp. 277-9o.

Allen, Peter Lewis, The Wages of Sin: Sex and Disease, Past and Present (Chicago: University of Chicago Press, 2000).

Amat, Trigit, 'Jesus Cross with Animation/holy cross crucifix god christ christianity church', Second Life Marketplace, ([n.d.]), https://marketplace.secondlife.com/p/Jesus-Cross-withAnimation-holy-cross-crucifix-god-christ-christianity-church/790522 [accessed 8 August 2016].

—, personal communication with the author in Second Life, 17 August 2016.

D'Anastasio, Cecilia, 'Men Are Working Out Their Issues By Playing as Their Lovers and Exes in RPGs', Motherboard (28 April 2016), http://motherboard.vice.com/read/men-are-working-outtheir-issues-by-playing-as-their-lovers-and-exes-in-rpgs [accessed 22 August 2016].

Andolsen, Barbara Hilkert, 'Agape in Feminist Ethics', in Feminist Theological Ethics: A Reader, ed. by Lois K. Daly (Louisville, KY: Westminster John Knox Press, 1994), pp. 146-59 (first publ. in Journal of Religious Ethics, 9.1 (1981), 69-83).

Annese, Susanna, 'Mediated Identity in the Parasocial Interaction of TV', Identity, 4.4 (2009), 371-88.

Appelmans, Janick, 'The Abbey of Affligem and the Emergence of a Historiographic Tradition in Brabant (1268-1322)', in Medieval Narrative Sources: A Gateway into the Medieval Mind, ed. by Werner Verbeke, Ludovicus Milis, and Jean Goossens (Leuven: Leuven University Press, 2005), pp. 163-80.

Atkinson, Clarissa W. "“This Creature”: 40 Years of Margery Kempe', Oldest Vocation (24 February 2015), https://oldestvocation.wordpress.com/2015/02/24/this-creature-40-years-of-margerykempe/ [accessed 27 May 2016].

—, 'Female Sanctity in the Late Middle Ages', in The Book ofMargery Kempe: A New Translation, Contexts, Criticism, ed. by Lynn Staley (New York: Norton, 2001), pp. 225-36.

$\mathrm{Au}$, Wagner James, 'Lindens Advertise Second Life With Avatar Like Avatar From *Avatar* (But Not For Much Longer) - Updated: User Activity in Second Life Increases During Campaign, Says Tateru Nino', Notes from the New World, (14 January 2010), http://nwn.blogs.com/ nwn/2010/o1/avatar-not-an-avatar-avatar.html [accessed 8 August 2016].

—, The Making of Second Life: Notes from the New World (London: Collins, 2008).

—, 'Second Life's Reported Monthly Active Users Drop To 800,000, Down 200K Since 2014 - "Paying SL Users Has Held Steady", Says Linden Lab', Notes from the New World, (16 February 2017), http://nwn.blogs.com/nwn/2017/02/second-life-monthly-users- 8000oo.html [accessed 7 April 2017].

Aurthur, Kate, 'Here's How “Keeping Up With The Kardashians” Dealt With The Paris Robbery', BuzzFeed, (20 March 2017), https://www.buzzfeed.com/kateaurthur/heres-how-keepingup-with-the-kardashians-dealt-with-the?utm_term=.xx2ZDbwlq\#.saWJdo5Bo [accessed 28 March 2017].

Auslander, Philip, Liveness: Performance in a Mediatized Culture (New York: Routledge, 1999). 'avatar, n.', in Oxford English Dictionary Online (Oxford: Oxford University Press, 200o), http:// www.oed.com/ [accessed 14 July 2016].

Aykroyd Peter H., and Angela Narth, A History of Ghosts: The True Story of Séances, Mediums, Ghosts, and Ghostbusters (New York: Rodale, 2009).

Bakhtin, Mikhail Mikhailovich, The Dialogic Imagination: Four Essays, ed. by Michael Holquist, trans. by Caryl Emerson and Michael Holquist (Austin: University of Texas Press, 1981). 
Bale, Anthony, 'Woman in White: Why Margery Kempe Divides Modern Readers as Much as She Did Her Medieval Audience', Times Literary Supplement, 19 December 2014, pp. 16-17.

Barker, Jennifer M., The Tactile Eye: Touch and the Cinematic Experience (Berkeley: University of California Press, 2009).

Barthes, Roland, Camera Lucida, trans. by Richard Howard (London:Vintage Books, 2000 (1981)).

Bartoli, Marco, 'Les femmes et l'Église au XIIIe siècle', in Fête-Dieu (1246-1996), ed. by André Haquin and Jean-Pierre Delville, 2 vols (Louvain-la-Neuve: Institut d'Études Médiévales de l'Université Catholique de Louvain, 1999), I, 55-79.

Bastida, Rebeca Sanmartín, 'La construcción de la santidad en María de Santo Domingo: la imitación de Catalina de Siena', Ciencia Tomista, 140 (2013), 141-59.

- La representación de las místicas: Sor María de Santo Domingo en su contexto europeo (Santander, Spain: RSMP, 2012).

—, 'Santa Teresa y la herencia de las visionarias del Medievo: de las monjas de Helfta a María de Santo Domingo', Analecta Malacitana, 36.1-2 (2013), 275-87.

Batchen, Geoffrey, 'Vernacular Photographies', History of Photography, 24.3 (2000) 262-71.

Bazin, André, Qu'est-ce que le cinéma?, 20 edn (Paris: Éditions du Cerf, 2011).

-, What is Cinema?, trans. by Hugh Gray, 2 vols. (Berkeley: University of California Press, 1967 (repr. 2005)).

Beaumont, Shona, 'Let There Be Light: Theology and Spirituality in Early Photography', paper presented at the Rethinking Early Photography Conference, University of Lincoln, UK (17 June 2015), http://www.shospace.co.uk/2015/o3/let-there-be-light/ [accessed 29 January 2016].

'Begging to See Czolgosz's Death', New YorkJournal, 22 October 1901, p. 1.

Belamire, Jordan, 'My First Virtual Reality Groping', Medium (2o October 2016), https://medium. com/athena-talks/my-first-virtual-reality-sexual-assault-233041ob62ee [accessed 15 May 2017].

Bellour, Raymond, Le Corps du cinéma : hypnoses, émotions, animalités (Paris: P.O.L., 2009).

Belting, Hans, Likeness and Presence: A History of the Image before the Era of Art, trans. by Edmund Jephcott (Chicago: University of Chicago Press, 1994).

Bennett, Judith M., 'Medieval Women in Modern Perspective', in Women's History in Global Perspective, ed. by Bonnie G. Smith, 3 vols (Champaign, IL: University of Illinois Press, 2004-2005), II (2005), 139-86.

Bériou, Nicole, L'Avènement des maîtres de la parole: la prédication à Paris au XIIIe siècle, 2 vols (Paris: Insititute d'études augustiniennes, 1998), II.

Berlanstein, Lenard R., 'Historicizing and Gendering Celebrity Culture: Famous Women in Nineteenth-Century France', Journal of Women's History, 16.4 (2004), 65-91.

Berlière, Ursmer, 'Guillaume de Ryckel, abbé de St-Trond et les reliques des saints de Cologne', Revue bénédictine, 16 (1899), 270-77.

Berlioz, Jacques, and Marie-Anne Polo de Beaulieu, 'Les Prologues des recueils d'exempla (XIIIe-XIVe siècles): une grille d'analyse', in La Predicazione dei Frati dalla metà del '20o alla fine del '3oo, ed. by Edith Pasztor (Spoleto: Centro italiano di Studi sull'alto medioevo, 1995), pp. 268-99.

Berlioz, Jacques, and Colette Ribaucourt, 'Images de la confession dans la prédication au début du XIVe siècle: l'exemple de l'Alphabetum narrationum d'Arnold de Liège', in Pratiques de la confession: des pères du désert à Vatican II, ed. by Groupe de la Bussière (Paris: Éditions du Cerf, 1983), pp. 95-115.

Bernasconi, Gianenrico, 'The Nature Self-Print', in Objects in Transition: An Exhibition at the Max Planck Institute for the History of Science, Berlin; August 16-September 2, 2007, ed. by Susanne Pickert, Gianenrico Bernasconi, and Anna Maerker (Berlin: Max-Planck-Institut für Wissenschaftsgeschichte, 2007), pp. 14-23. 
Biddick, Kathleen, The Shock of Medievalism (Durham: Duke University Press, 1998).

Biernoff, Suzannah, Sight and Embodiment in the Middle Ages (Basingstoke, UK: Palgrave, 2002).

Biressi, Anita, and Heather Nunn, Reality TV: Realism and Revelation (New York: Columbia University Press, 2005).

Bjørnvig, Thore, 'Outer Space Religion and the Ambiguous Nature of Avatar's Pandora', in Avatar and Nature Spirituality, ed. by Bron Taylor (Waterloo, Canada: Wilfred Laurier University Press, 2013), pp. 37-6o.

Boellstorff, Tom, Coming of Age in Second Life: An Anthropologist Explores the Virtually Human (Princeton: Princeton University Press, 2008).

Boersma, Hans, Heavenly Participation: The Weaving of a Sacramental Tapestry (Grand Rapids, MI: Eerdmans Publishing, 2011).

Bolter, Jay David, 'Transference and Transparency: Digital Technology and the Remediation of Cinema', Intermédialités, 6 (2005), 13-26.

Borland, Jennifer, 'Unruly Reading: The Consuming Role of Touch in the Experience of a Medieval Manuscript', in Scraped, Stroked, and Bound: Materially Engaged Readings of Medieval Manuscripts, ed. by Jonathan Wilcox (Turnhout: Brepols, 2013), pp. 97-114.

—, 'Violence on Vellum: St Margaret's Transgressive Body and its Audience', in RMG, pp. 67-87.

Box Office Mojo, 'All Time Worldwide Box Office Grosses', Box Office Mojo, (n.d.), http://www. boxofficemojo.com/alltime/world/ [accessed 7 April 2017].

Braudy, Leo, The Frenzy of Renown: Fame and its History (New York: Vintage, 1986).

Bresc, Henri, 'Culture folklorique et théologique: Le revenant de Beaucaire (1211)', Razo: Cahiers du Centre d'études médiévales de Nice, 8 (1988) 65-74.

Brody, Saul Nathaniel, The Disease of the Soul:Leprosy in MedievalLiterature (Ithaca, NY: Cornell University Press, 1974).

Brown, Catherine, 'In the Middle', Journal of Medieval and Early Modern Studies, 30.3 (2000), 547-74.

—, 'Manuscript Thinking: Stories by Hand', postmedieval, 2 (2011), 350-68.

Brown, Jennifer N., 'The Chaste Erotics of Marie d'Oignies and Jacques de Vitry', Journal of the History of Sexuality, 19.1 (2010), 74-93.

—, 'Christina Mirabilis: Astonishing Piety', in TWOL, pp. 219-45.

—, 'Introduction', in TWOL, pp. 1-25.

—, 'Marie d'Oignies: The Vita of Jacques of Vitry', in TWOL, pp. 247-87.

Brown, Melissa, 'Marie d'Oignies, Marguerite Porete and "Authentic" Female Mystic Piety in the Middle Ages', in Worshipping Women: Misogyny and Mysticism in the Middle Ages, ed. by G. Francesca Bussey and O. John Ward (Sydney: University of Sydney, 1997), pp. 187-235.

Bruns, Axel, Blogs, Wikipedia, Second Life, and Beyond: From Production to Produsage (New York: Peter Lang, 2008).

—, 'Produsage: Towards a Broader Framework for User-Led Content', in Proceedings of the 6th ACM SIGCHI Conference on Creativity \& Cognition (New York: ACM, 2007), pp. 99-105.

—, 'Towards Produsage: Futures for User-Led Content Production', in Proceedings: Cultural Attitudes towards Communication and Technology 20o6, ed. by Fay Sudweeks, Herbert Hrachovec, and Charles Ess (Perth, Australia: Murdoch University, 20o6), pp. 275-84.

Burch, Noël, Life to Those Shadows, trans. by Ben Brewster(London: British Film Institute, 199o). Burgess, Jean, and Joshua Green, YouTube: Online Video and Participatory Culture (Cambridge, UK: Polity, 2009).

Burt, C. David, 'Anglican and Other Churches in Second Life', CDBURT, (2010), http://home. comcast.net/ cdburt/site/?/page/Anglican_and_Other_Churches_in_Second_Life/\&PHP SESSID=f12051ce6408454bo279982011c5d45b [accessed 19 November 2010]. 
—, 'Catholic and Orthodox Churches in Second Life', CDBURT, (2010), http://home.comcast. net/ cdburt/site/?/page/Catholic_and_Orthodox_Churches_in_Second_Life/ [accessed 19 November 2010].

Byers, Stephen Francis, Clerical Role Play in the Archdiocese of Lepanto (24 September 2016). Second Life Notecard.

Bynum, Caroline Walker, Christian Materiality: An Essay on Religion in Late Medieval Europe (New York: Zone Books, 2011).

-, Fragmentation and Redemption: Essays on Gender and the Human Body in Medieval Religion (New York: Zone Books, 1991).

-, Holy Feast and Holy Fast: The Religious Significance of Food to Medieval Women (Berkeley: University of California Press, 1987).

—, The Resurrection of the Body in Western Christianity, 200-1336 (New York: Columbia University Press, 1995).

Caciola, Nancy, 'Mystics, Demoniacs, and the Physiology of Spirit Possession in Medieval Europe', Comparative Studies in Society and History, 42.2 (2000), 268-306.

Camille, Michael, 'Before the Gaze: The Internal Sense and Late Medieval Practices of Seeing', in Visuality Before and Beyond the Renaissance: Seeing as Others Saw, ed. by Robert S. Nelson (Cambridge: Cambridge University Press, 2000), pp. 197-223.

Campbell, Emma, Medieval Saints'Lives: The Gift, Kinship and Community in Old French Hagiography (Cambridge, UK: Brewer, 2008).

- 'Sacrificial Spectacle and Interpassive Vision in the Anglo-Norman Life of Saint Faith', in Troubled Vision: Gender, Sexuality, and Sight in Medieval Text and Image, ed. by Emma Campbell and Robert Mills (New York: Palgrave Macmillan, 2004), pp. 97-115.

Campbell, Emma, and Robert Mills, 'Introduction: Troubled Vision', in Troubled Vision: Gender, Sexuality, and Sight in Medieval Text and Image, ed. by Emma Campbell and Robert Mills (New York: Palgrave Macmillan, 2004), pp. 1-14.

-, eds., Troubled Vision: Gender, Sexuality, and Sight in Medieval Text and Image (New York: Palgrave Macmillan, 2004).

Campion, Eleanor, 'Bernard and Alice the Leper: An Odor of Life for Some', Cistercian Studies Quarterly, 39.2 (2004) 127-39.

Cantavella, Rosanna, 'Dos preguntas sobre 'La Celestina': concordancias con obras catalanas medievales', in Cinco siglos de 'Celestina': aportaciones interpretativas, ed. by Rafael Beltrán and José Luis Canet (Valencia, Spain: Universitat de València, 1997), pp. 61-76.

Carozzi, Claude, 'Douceline et les Autres', Cahiers de Fanjeaux, 11 (1976), 251-67.

Carpenter, Jennifer, 'The Communities of a Thirteenth-Century Holy Woman, Ida of Nivelles', in Communities of Women: Historical Perspectives, ed. by Barbara Brookes and Dorothy Page (Dunedin, New Zealand: University of Otago Press, 2002), pp. 27-38.

—, 'A New Heaven and a New Earth: The Vitae of the Mulieres Religiosae of Liège' (unpublished doctoral dissertation, University of Toronto, 1997).

Carroll, Larry, “'Dark Knight” Dilemma: How Did Heath Ledger's Death Affect Film's Marketing?', MTVNews [Online], (11 July 2008) http://www.mtv.com/news/1590791/dark-knight-dilemmahow-did-heath-ledgers-death-affect-films-marketing/ [accessed 8 April 2017].

Carruthers, Mary, 'Meditations on the "Historical Present" and "Collective Memory" in Chaucer and Sir Gawain and the Green Knight', in Time in the Medieval World, ed. by Chris Humphrey and W. M. Ormrod (York: York Medieval Press, 2001), pp. 137-55.

Casey, Cheryl, 'Virtual Ritual, Real Faith: The Revirtualization of Religious Ritual in Cyberspace', Online, 2.1 (2006), 73-9o. 
Cashmore, Ellis, Celebrity/Culture (New York: Routledge, 2006).

Caviness, Madeline Harrison, Visualizing Women in the Middle Ages: Sight, Spectacle, and Scopic Economy (Philadelphia: University of Pennsylvania Press, 2001).

Cawley, Martinus, 'Introduction', in VAS, pp. v-xxx.

—, 'Introduction to the Lives', in $S M G$, pp. 1-26.

Cazelles, Brigitte, Le Corps de sainteté: d'après Jehan Bouche d'Or, Jehan Paulus et quelques vies des XIIe et XIIIe siècles (Geneva: Droz, 1982).

—, The Lady as Saint: A Collection of French Hagiographic Romances of the Thirteenth Century (Philadelphia: University of Pennsylvania Press, 1991).

Chang, Justin, 'Film Review: The Dark Knight', Variety [Online], (6 July 2008), http://variety. com/2008/film/markets-festivals/the-dark-knight-4-1200508584/ [accessed 8 April 2017].

Charlton, Corey, “ANYTHING FOR RATINGS” Cruel Trolls Claim Kim Kardashian's Terrifying Armed Robbery at her Paris Apartment was All a Sick Publicity Stunt', The Sun [Online], (3 October 2016), https://www.thesun.co.uk/news/190460o/cruel-trolls-claim-kim-kardashiansterrifying-armed-robbery-at-her-paris-apartment-was-all-a-sick-publicity-stunt/ [accessed 30 March 2017].

Chaudhuri, Shohini, Feminist Film Theorists: Laura Mulvey, Kaja Silverman, Teresa de Lauretis, Barbara Creed (London: Routledge, 2006).

Chee, Florence, Marcelo Vieta, and Richard Smith, 'Online Gaming and the Interactional Self: Identity Interplay in Situated Practice', in Gaming as Culture: Essays on Reality, Identity and Experience in Fantasy Games, ed. by J. Patrick Williams, Sean Q. Hendricks, and W. Keith Winkler (Jefferson, NC: McFarland, 2006), pp. 154-74.

Cherchi, Paolo, 'Gervase of Tilbury and the Birth of Purgatory', Medioevo romanzo, 14 (1989) 97-110.

Chester, Jason, and Chelsea White, “Bye, bye”: The Chilling Words Heath Ledger Scrawled at the End of a Journal he Kept While Preparing for his Role as the Joker are Revealed as German Doco Resurfaces', Daily Mail [Online], (11 August 2015), http://www.dailymail.co.uk/ tvshowbiz/article-3193027/Documentary-Heath-Ledger-s-father-reveals-journal-actor-keptprepared-role-Joker-resurfaces.html [accessed 21 January 2016].

Chidester, David, 'Sacred', Material Religion, 7.1 (2011), 84-90.

Christie, Ian, 'Early Phonograph Culture and Moving Pictures', in The Sounds of Early Cinema, ed. by Richard Abel and Rick Altman (Bloomington and Indianapolis: Indiana University Press, 2001), pp. 3-12.

Church Pension Fund, Holy Women, Holy Men: Celebrating the Saints. Conforming to General Convention 2009 (New York: Church Publishing, 2010).

Clinnin, Kaitlin, 'Playing with Masculinity: Gender Bending in Second Life', Technoculture: An Online Journal of Technology in Society, 3 (2013), https://tcjournal.org/drupal/vol3/clinnin [accessed 27 September 2016].

Coakley, John Wayland, Women, Men, and Spiritual Power: Female Saints and their Male Collaborators (New York: Columbia University Press, 2006).

Coens, Maurice, 'Les Saints particulièrement honorés à l'Abbaye de Saint-Trond', Analecta Bollandiana, 72 (1954), 397-426.

Cohen, Esther, 'Symbols of Culpability and the Universal Language of Justice: The Ritual of Public Executions in Late Medieval Europe', History of European Ideas, 11 (1989) 407-16, http:// dx.doi.org/10.1016/0191-6599(89)90228-3 [accessed 2 May 2017].

Cohn-Sherbok, Lavinia, ed., Who's Who in Christianity (London: Routledge, 1998).

Collet, Emmanuel, The Treasure of Oignies, trans. by Liz Harrison (Brussels: King Baudouin Foundation, 2012). Electronic book. http://fr.calameo.com/read/o037220509dcd5da6cba2 [accessed 26 February 2017]. 
Combs, C. Scott, Deathwatch:American Film, Technology, and the End of Life (New York: Columbia University Press, 2014).

Congressional Record, $60^{\text {th }}$ Congress, $1^{\text {st }}$ session, vol. XLII, part 5: [Senate, 9 April 1908] p. $45^{2} 6$ and [House of Representatives, 13 April 1908] pp. 4698-99.

Cooper, Sarah, The Soul of Film Theory (Basingstoke, UK: Palgrave Macmillan, 2013).

Corbellini, Sabrina, 'Introduction', in Cultures of Religious Reading in the Late Middle Ages: Instructing the Soul, Feeding the Spirit, and Awakening the Passion, ed. by Sabrina Corbellini (Turnhout: Brepols, 2013), pp. 1-11.

Corinthios, Aurelie, Julia Emmanuele, and Lanford Beard, 'Everything We Know About Kim Kardashian West's Paris Heist', People [Online], (16 March 2017), http://people.com/tv/kimkardashian-robbery-questions-answered/ [accessed 31 March 2017].

Cote, Rachel Vorona, 'The Agony and the Ecstasy of the Ugly Cry', New Republic (1 April 2016), https://newrepublic.com/article/132289/agony-ecstasy-ugly-cry [accessed 21 July 2016].

Courtoy, Ferdinand, 'Le trésor du prieuré d'Oignies aux soeurs de Notre-Dame à Namur et l'oeuvre du Frère Hugo', Bulletin van de Koninklijke Commissie voor Monumenten en Landschappen, 3 (1951-1952), 121-256.

Craun, Marlys, 'The Story of Margery Kempe', Psychiatric Services, 56.6 (2005), 655-56.

Crombie, A.C., Robert Grosseteste and the Origins of Experimental Science, 1100-1700 (Oxford, UK: Clarendon Press, 1953).

Daily Mail Reporter, 'Victoria Beckham, Jessica Simpson and Eva Longoria's Favourite Hollywood Hair Guru Ken Pavés Shares his Secrets', Daily Mail [Online] (3 July 2013), http:// www.dailymail.co.uk/tvshowbiz/article-2355207/Victoria-Beckham-Jessica-Simpson-EvaLongorias-favourite-hair-guru-Ken-Paves-shares-secrets.html [accessed 13 July 2016].

Dalmasso, Anna Caterina, 'Toucher l'écran : le chiasme entre visuel et tactile dans l'expérience filmique', in Merleau-Ponty e l'estetica oggi-Merleau-Pontyet l'esthétique aujourd'hui, ed. by Mauro Carbone, Anna Caterina Dalmasso, and Elio Franzini (Milan:Mimesis, 2013), pp. 67-91.

—, 'Voir selon l'écran: autour d'une rencontre entre visibilité et théorie filmique', in L'empreinte duvisuel:Merleau-Pontyet les images aujourd'hui, ed. by Mauro Carbone (Geneva: MetisPress, 2013), pp. 107-26.

'The Dark Knight', in Metacritic [Online database] (n.p.), http://www.metacritic.com/movie/ the-dark-knight/critic-reviews [accessed 8 April 2017].

Davies, Rebecca, 'The critics' verdict on Heath Ledger in The Dark Knight', The Telegraph [Online], (16 July 2008), http://www.telegraph.co.uk/culture/film/filmreviews/3556524/ The- critics-verdict-on-Heath-Ledger-in-The-Dark-Knight.html [accessed 8 April 2017].

Davis, Donna Z., 'Gendered Performance in Virtual Environments', in Media Disparity: A Gender Battleground, ed. by Cory L. Armstrong (Lanham, MD: Lexington Books, 2013), pp. 133-46.

Davison, Rebecca, “Should have shot her... lol!” Kim Kardashian is Attacked by Cruel Trolls on Social Media Following Horrific Gunpoint Attack in Paris', Daily Mail [Online], (3 October 2016), http://www.dailymail.co.uk/tvshowbiz/article-3819268/Should-shot-lol-KimKardashian-attacked-cruel-trolls-social-media-following-horrific-gunpoint-attack-Paris. html [accessed 31 March 2017].

Deane, Jennifer Kolpacoff, 'Elastic Institutions: Beguine Communities in Early Modern Germany', in Devout Laywomen in the Early Modern World, ed. by Alison Weber (Abingdon, UK: Routledge, 2016), pp. 175-95.

Delehaye, Hippolyte, Les légendes hagiographiques, 2nd edn (Brussels: Bureaux de la Société des Bollandistes, 1906).

Deleuze, Gilles, Cinema 1: The Movement-Image, trans. by Hugh Tomlinson and Barbara Habberjam (Minneapolis: University of Minnesota Press, 1986). 
Delle Stelle, Anne-Laure Méril-Bellini, 'Caritas et familiaritas à l'ombre du Seigneur: les relations des mulieres religiosae des Pays-Bas méridionaux du 13ème siècle avec leur entourage' (unpublished doctoral thesis, Université de Toulouse, 2012).

Denby, David, 'Past Shock: “The Dark Knight” and “WALL-E”', New Yorker, (21 July 2008), http:// www.newyorker.com/magazine/2008/07/21/past-shock [accessed 19 January 2016].

Denery, Dallas G., Seeing and Being Seen in the Later Medieval World: Optics, Theology, and Religious Life (Cambridge: Cambridge University Press, 2005).

Deploige, Jeroen, 'How Gendered was Clairvoyance in the Thirteenth Century?: The Case of Simon of Aulne', in Speaking to the Eye: Sight and Insight through Text and Image (1150-1650), ed. by Thérèse de Hemptinne, Veerle Fraeters, and María Eugenia Góngora (Turnhout: Brepols, 2013), pp. 95-119.

Dietz, Jason, 'Film Critics Pick the Best Movies of the Decade', Metacritic, (3January 2010), http:// www.metacritic.com/feature/film-critics-pick-the-best-movies-of-the-decade [accessed 7 April 2017].

'DNA Testing May Unlock Secrets of Medieval Manuscripts', North Carolina State University, (2009), http://www.eurekalert.org/pub_releases/2009-01/ncsu-dtm010509.php [accessed 21 December 2012].

Doane, Mary Ann, The Emergence of Cinematic Time: Modernity, Contingency, the Archive (Cambridge, MA: Harvard University Press, 2002).

von Dobschütz, Ernst, Christusbilder: Untersuchungen zur christlichen Legende (Leipzig: Hinrichs'suche, 1899).

Donald, James, ed., Chambers's Etymological Dictionary of the English Language (Edinburgh and London: W. \& R. Chambers, 1872).

Donati, Ana R. C., Solaiman Shokur, Edgard Morya, Debora S. F. Campos, Renan C. Moioli, Claudia M. Gitti, Patricia B. Augusto, Sandra Tripodi, Cristhiane G. Pires, Gislaine A. Pereira, Fabricio L. Brasil, Simone Gallo, Anthony A. Lin, Angelo K. Takigami, Maria A. Aratanha, Sanjay Joshi, Hannes Bleuler, Gordon Cheng, Alan Rudolph, and Miguel A.L. Nicolelis, 'Long-Term Training with a Brain-Machine Interface-Based Gait Protocol Induces Partial Neurological Recovery in Paraplegic Patients', Nature Scientific Reports, 6 (2016) article 30383, http://dx.doi. org/10.1038/srep30383 [accessed 16 August 2016].

Dor, Juliette, Lesley Johnson, and Jocelyn Wogan-Browne, eds., New Trends in Feminine Spirituality: The Holy Women of Liège and their Impact (Turnhout: Brepols, 1999).

Dovey, Jon, Freakshow: First Person Media and Factual Television (London: Pluto Press, 2000).

Drax, Bernhard, Skype interview with the author, 4 May 2016.

Drescher, Elizabeth, Choosing Our Religion: The Spiritual Lives of America's Nones (Oxford: Oxford University Press, 2016).

Drout, Michael, 'Crazy Sheep DNA Project Progress', Wormtalk and Slugspeak, (2007), http:// wormtalk.blogspot.co.uk/2007/07/crazy-sheep-dna-project-progress.html [accessed 21 December 2012].

—, 'The Prototype of the Manuscript DNA Extractor Now Sits on My Desk', Wormtalk and Slugspeak, (2010), http://wormtalk.blogspot.co.uk/2010/03/prototype-of-manuscript-dnaextractor.html [accessed 21 December 2012].

—, 'Sheep DNA and Manuscripts (Again)', Wormtalk and Slugspeak, (2009), http://wormtalk. blogspot.co.uk/2009/o1/sheep-dna-and-manuscripts-again-i-meant.html [accessed 21 December 2012].

Dunn, Robert Andrew, 'Identity Theories and Technology', in Handbook of Research on Technoself: Identity in a Technological Society, ed. by Rocci Luppicini (Hershey, PA: IGI Global, 2013), pp. 28-44. 
Dyer, Richard, Heavenly Bodies: Film Stars and Society (New York: St. Martin's Press, 1986).

—, Stars (London: BFI, 1979).

Easton, Martha, 'Transforming and Transcending Gender in the Lives of Female Saints', in The Four Modes of Seeing: Approaches to Medieval Imagery in Honor of Madeline Harrison Caviness, ed. by Elizabeth Pastan, Ellen M. Shortell, and Evelyn Staudinger Lane (London: Ashgate Press, 2009), pp. 333-47.

Ebert, Roger, 'The Dark Knight', rogerebert.com, (16 July 2008), http://www.rogerebert.com/ reviews/the-dark-knight-2008 [accessed 19 January 2016].

'Edison 1901 Projecting Kinescope' [advert], New York Clipper, 16 November 1901, p. 832, Illinois Digital Newspaper Collections, http://idnc.library.illinois.edu/cgi- bin/ illinois?a=d\&d=NYC19o11116\&e=-------en-20--1--txt-txIN------- [accessed 22 January 2016].

Edwards, Leigh H., The Triumph of Reality TV: The Revolution in American Television (Santa Barbara, CA: Praeger, 2013).

Elliott, Dyan, Proving Woman: Female Spirituality and Inquisitional Culture in the Later Middle Ages (Princeton: Princeton University Press, 2004).

—, Spiritual Marriage: Sexual Abstinence in Medieval Wedlock (Princeton: Princeton University Press, 1995).

Ellis, Roger, 'Margery Kempe's Scribe and the Miraculous Books', in Langland, the Mystics and the MedievalEnglish Religious Tradition:Essays in Honour of S. S. Hussey, ed. by Helen Phillips (Cambridge, UK: Brewer, 1990), pp. 161-75.

L'Estrange, Elizabeth, and Alison More, 'Representing Medieval Genders and Sexualities in Europe: Construction, Transformation, and Subversion, 600-1530', in $R M G$, pp. 1-13.

-, eds., Representing Medieval Genders and Sexualities in Europe: Construction, Transformation, and Subversion, 60o-1530 (Farnham, UK: Ashgate, 2011).

Evans, Ruth, 'The Book of Margery Kempe', in A Companion to Medieval English Literature and Culture, c.1350-c.1500, ed. by Peter Brown (Oxford: Blackwell, 2007), pp. 507-21.

'Execution of Czolgosz', New York Times, 15 October 1901, p. 11.

Farley, Margaret A., 'New Patterns of Relationship: Beginnings of a Moral Revolution', Theological Studies, 36.4 (1975), 627-46.

Farmer, Sharon, 'Low Country Ascetics and Oriental Luxury: Jacques de Vitry, Marie of Oignies, and the Treasures of Oignies', in History in the Comic Mode: Medieval Communities and the Matter of Person, ed. by Rachel Fulton and Bruce W. Holsinger (New York: Columbia University Press, 2007), pp. 205-22.

Fetscherin, Marc, and Christoph Lattemann, 'User Acceptance of Virtual Worlds', Journal of Electronic Commerce Research, 9.3 (2008), 231-42.

Fiddyment, Sarah, Bruce Holsinger, Chiara Ruzzier, Alexander Devine, Annelise Binois, Umberto Albarella, Roman Fischer, Emma Nichols, Antoinette Curtis, Edward Cheese, Matthew D. Teasdale, Caroline Checkley-Scott, Stephen J. Milner, Kathryn M. Rudy, Eric J. Johnson, Jiří Vnouček, Mary Garrison, Simon McGrory, Daniel G. Bradley, and Matthew J. Collins, 'Animal Origin of 13 th-Century Uterine Vellum Revealed Using Noninvasive Peptide Fingerprinting', PNAS: Proceedings of the National Academy of Sciences of the United States of America, 112.49 (2015) 15066-15071, http://www.pnas.org/content/112/49/15066 [accessed 14 April 2017].

Fiorenza, Elisabeth Schüssler, But She Said:Feminist Practices of Biblical Interpretation (Boston: Beacon Press, 1992).

—, 'Introduction: Exploring the Intersections of Race, Gender, Status, and Ethnicity in Early Christian Studies', in Prejudice and Christian Beginnings: Investigating Race, Gender, and 
Ethnicity in Early Christian Studies, ed. by Laura Salah Nasrallah and Elisabeth Schüssler Fiorenza (Minneapolis: Fortress Press, 2009), pp. 1-23.

First UCC SL, 'Homepage', First UCC SL, http://firstuccsl.org/index.html [accessed 30 September 2016].

Flory, David A., 'The Social Uses of Religious Literature: Challenging Authority in the ThirteenthCentury Marian Miracle Tale', Essays in Medieval Studies, 13 (1996), 61-69.

Folda, Jaroslav, Crusader Art in the Holy Land:From the Third Crusade to the Fall of Acre, 1187-1291 (Cambridge: Cambridge University Press, 2005).

Folger, Robert, Escape from the Prison of Love: Caloric Identities and Writing Subjects in FifteenthCentury Spain (Chapel Hill: University of North Carolina Press, 2009).

Folkerts, Suzan, 'The Manuscript Transmission of the Vita Mariae Oigniacensis in the Later Middle Ages', in MOS, pp. 221-41.

Fradenburg, Louise, “'So That We May Speak of Them”: Enjoying the Middle Ages', New Literary History, 28.2 (1997), 205-30.

Frankowska-Terlecka, Małgorzata, “Scientia” as Conceived by Roger Bacon', Organon, 6 (1969), 209-31.

Freeman, Phyllis R., Carley Rees Bogarad, and Diane E. Sholomskas, 'Margery Kempe, a New Theory: The Inadequacy of Hysteria and Postpartum Psychosis as Diagnostic Categories', History of Psychiatry, 1 (1990), 169-9o.

Funk, Philipp, Jakob von Vitry: Leben und Werke (Leipzig: Druck, 1909).

Galloway, Penny, 'Neither Miraculous nor Astonishing: The Devotional Practice of Beguine Communities in French Flanders', in NTFS, pp. 107-27.

Ganesvoort, Harper, 'Archive for the "Religion” Category', Around the Grid, (25January 2008-present), https://harper-ganesvoort.com/category/religion/ [accessed 16 August 2016].

Gannes, Liz, 'The Incredible Oversharing Endurance of Kim Kardashian West (Full Session Video)', Recode.net (29 October 2014), http://www.recode.net/2014/10/29/11632436/theincredible-oversharing-endurance-of-kim-kardashian-west-full [accessed 21 July 2016].

Garber, Megan, 'You Win, Kim Kardashian', The Atlantic [Online] (13 May 2015), http://www. theatlantic.com/entertainment/archive/2015/05/kim-kardashian-selfish/393113/ [accessed 19 July 2016].

Germano, William, From Dissertation to Book (Chicago: University of Chicago Press, 2005 (repr. 2013)).

Gemixin, 'UK Second Life Time Converter', ([n.d.]), http://gemixin.co.uk/slconverter/slconvert. php [accessed 18 August 2016].

Gibbons, Ann, 'Goats, Bookworms, a Monk's Kiss: Biologists Reveal the Hidden History of Ancient Gospels', Science [Online], 25 July 2017, http://www.sciencemag.org/news/2017/07/ goats-bookworms-monk-s-kiss-biologists-reveal-hidden-history-ancient-gospels [accessed 18 August 2017].

Giles, David, Illusions of Immortality: A Psychology of Fame and Celebrity (New York: St. Martin's Press, 2000).

Gilleir, Anke, and Alicia C. Montoya, 'Introduction: Women's Literary History', in Women Writing Back/Writing Women Back: Transnational Perspectives from the Late Middle Ages to the Dawn of the Modern Era, ed. by Anke Gilleir, Alicia C. Montoya, and Suzanna van Dijk (Leiden: Brill, 2010), pp. 1-20.

Giordano, Maria Laura, 'Historicizing the Beatas: The Figures Behind Reformation and CounterReformation Conflicts', in Devout Laywomen in the Early Modern World, ed. by Alison Weber (Abingdon, UK: Routledge, 2016), pp. 91-111. 
Givhan, Robin, 'Why are People Mocking Kim Kardashian for Being a Victim of Violent Crime?', Washington Post [Online] (3 October 2016), https://www.washingtonpost.com/news/ arts-and-entertainment/wp/2016/10/03/why-are-we-mocking-kim-kardashian-for-beinga-victim-of-violent-crime/?utm_term=.5f115275 f5 d7 [accessed 30 March 2017].

Goodich, Michael, 'The Contours of Female Piety in Later Medieval Hagiography', Church History, 50.1 (1981), 20-32.

—, ed., Other Middle Ages: Witnesses at the Margins of Medieval Society (Philadelphia: University of Pennsylvania Press, 1998).

Goodman, Anthony, 'Margery Kempe', in Medieval Holy Women in the Christian Tradition, $c$. 1100-c. 1500, ed. by Alastair Minnis and Rosalynn Voaden (Turnhout: Brepols, 2010), pp. 217-38.

Google Trends, 'Top Charts 2014', Google.com ([n.d.]), http:/www.google.com/trends/ topcharts?hl=en\#date $=2014 \&$ geo $=[$ accessed 20 July 2016].

Gounelle, Remi, 'Les origines littéraires de la légende de Véronique et de la Sainte Face: la Cura sanitatis Tiberii et la Vindicta Saluatoris', in Sacre impronte e oggetti «non fatti da mano d'uomo » nelle religioni: Atti del convegno internazionale, Torino, 18-20 maggio 2010, ed. by A. Monaci Castagno (Turin: Edizioni dell'Orso, 2011), pp. 231-51.

Gray, Brandon, “'Dark Knight” Begins Smashingly', Box Office Mojo, (23July 20o8), http://www. boxofficemojo.com/news/?id=2504\&p=s.htm [accessed 19 January 2016].

Gray, Jonathan, Cornel Sandvoss, and C. Lee Harrington, eds., Fandom:Identities and Communities in a Mediated World (New York: New York University Press, 2007).

Green, Shoshanna, Cynthia Jenkins, and Henry Jenkins, "Normal Female Interest in Men Bonking": Selections from the Terra Nostra Underground and Strange Bedfellows', in Fans, Bloggers, and Gamers: Exploring Participatory Culture, ed. by Henry Jenkins (New York: New York University Press, 2006), pp. 61-88.

Griffith, Richard, The Movie Stars (New York: Doubleday, 1970).

Griffiths, Alison, 'Tableaux Morts: Execution, Cinema, and Galvanistic Fantasies', Republics of Letters: A Journal for the Study of Knowledge, Politics, and the Arts, 3.3 (2014) 1-32.

Griffiths, Mark D., Mark N.O. Davies, and Darren Chappell, 'Breaking the Stereotype: The Case of Online Gaming', CyberPsychology \& Behavior, 6.1 (2003), 81-91.

-, 'Demographic Factors and Playing Variables in Online Computer Gaming', CyberPsychology \& Behavior, 7.4 (2004), 479-87.

Grossel, Marie-Geneviève, 'La Vie de Marie d'Oignies par Jacques de Vitry: première biographie féminine?', Bien dire et bien aprandre, 20 (2000), 89-100.

Grossman, Cathy Lynn, 'Faithful Build a Second Life for Religion Online', USA Today [Online], (3 April 2007), http://www.usatoday.com/tech/gaming/2007-04-01-second-life-religion_N. htm [accessed 28 July 2016].

Guarnieri, Romana, 'Pinzochere', in Dizionario degli istituti diperfezione, vol. 6, ed. by Guerrino Pellicia and Giancarlo Rocca (Rome: Edizioni Paoline, 1980), cols. 1721-49.

Gunning, Tom, 'Phantom Images and Modern Manifestations: Spirit Photography, Magic Theater, Trick Films, and Photography's Uncanny', in Cinematic Ghosts: Haunting and Spectrality from Silent Cinema to the Digital Era, ed. by Murray Leeder (London: Bloomsbury, 2015), pp. 17-38 (first publ. in Patrice Petro, ed., Fugitive Images: From Photography to Video (Bloomington: Indiana University Press, 1992), pp. 42-71)).

-, 'What's the Point of an Index? Or, Faking Photographs', in Still Moving: Between Cinema and Photography, ed. by Karen Beckman and Jean Ma (Durham, NC: Duke University Press, 2008), pp. 23-40.

Gurevich, Aaron J., Categories of Medieval Culture, trans. by G. L. Campbell (London, Boston, Melbourne, and Henley: Routledge and Kegan Paul, 1985). 
—, 'Medieval Chronotope', Theoretische Geschiedenis, 22.3 (1995) 225-40.

—, Medieval Popular Culture: Problems of Belief and Perception, trans. by János M. Bak and Paul

A. Hollingsworth (Cambridge: Cambridge University Press, 1985).

Hahn, Cynthia, 'Metaphor and Meaning in Early Medieval Reliquaries', in Seeing the Invisible in Late Antiquity and the Early Middle Ages, ed. by Giselle de Nie, Karl F. Morrison, and Marco Mostert (Turnhout: Brepols, 2005), pp. 239-63.

—, 'Objects of Devotion and Desire: Relics, Reliquaries, Relation, and Response', in Objects of Devotion and Desire: Medieval Relic to Contemporary Art, ed. by Cynthia Hahn (New York: Hunter College, 2011), pp. 8-20.

—, 'Visio Dei: Changes in Medieval Visuality', in Visuality Before and Beyond the Renaissance: Seeing as Others Saw, ed. by Robert S. Nelson (Cambridge: Cambridge University Press, 2000), pp. 169-96.

—, 'The Voices of the Saints: Speaking Reliquaries', Gesta, 36.1 (1997), 20-31.

—, 'What Do Reliquaries Do For Relics?', Numen, 57 (2010), 284-316.

Hamburger, Jeffrey F., The Visual and the Visionary: Art and Female Spirituality in Late Medieval Germany (New York: Zone Books, 1998).

Harding, Wendy, 'Body into Text: The Book of Margery Kempe', in Feminist Approaches to the Body in Medieval Literature, ed. by Linda Lomperis and Sarah Stanbury (Philadelphia: University of Pennsylvania Press, 1993), pp. 168-87.

Hassenger, Jesse, 'Ghostbusters, Frozen, and the Strange Entitlement of Fan Culture', The A.V. Club (25 May 2016), http://www.avclub.com/article/ghostbusters-frozen-and-strange-entitlementfan-cu-237139 [accessed 27 May 2016].

Herrick, Samantha Kahn, Imagining the Sacred Past: Hagiography and Power in Early Normandy (Cambridge, MA: Harvard University Press, 2007).

Hevern, Vincent W., 'Threaded Identity in Cyberspace: Weblogs and Positioning in the Dialogical Self', Identity, 4.4 (2004), 321-35.

Hills, Matt, Fan Cultures (London: Routledge, 2002).

—, 'Media Academics as Media Audiences: Aesthetic Judgments in Media and Cultural Studies', in Fandom: Identities and Communities in a Mediated World, ed. by Jonathan Gray, Cornel Sandvoss, and C. Lee Harrington (New York: New York University Press, 2007), pp. 33-47.

Hiltunen, Kaisa, 'Closeness in Film Experience: At the Intersection of Cinematic and Human Skin', Corpus: The Bodily Turn. Gesture, Gender and Sensation of the Art (Academic Cross Media Network, 2006-2010) ([n.d.]), http://www.corpus-aesthetics.net/doc/closeness_in_film_expirience.pdf [accessed 22 August 2012].

Hogan, Bernie, and Barry Wellman, 'The Immanent Internet Redux', in Digital Religion, Social Media and Culture: Perspectives, Practices and Futures, ed. by Pauline Hope Cheong, Peter Fischer-Nielsen, Stefan Gelfgren, and Charles Ess (New York: Peter Lang, 2012), pp. 43-62.

Hollywood, Amy, The Soul as Virgin Wife: Mechthild of Magdeburg, Marguerite Porete, and Meister Eckhart (Notre Dame: University of Notre Dame Press, 1995).

Holtmeier, Matthew, 'Post-Pandoran Depression or Na’vi Sympathy: Avatar, Affect, and Audience Reception', Journal for the Study of Religion, Nature \& Culture, 4.4 (2010), 414-24.

honestcoyote, 'Comment', MetaFilter (1 June 2016), http://www.metafilter.com/160093/Shescreating-it-and-whatever-she-creates-becomes-part-of-the-story $\# 6550208$ [accessed 3 June 2016].

Hooton, Christopher, 'A Look Inside Heath Ledger's Sinister "Joker journal" for The Dark Knight', Independent [Online], (10 August 2015), http://www.independent.co.uk/arts- entertainment/ films/news/a-look-inside-heath-ledger-s-sinister-joker-journal-10448048.html [accessed 21 January 2016]. 
Horak, Jan-Christopher, 'The Gap Between 1 and o: Digital Video and the Omissions of Film History', Spectator, 27.1 (2007) 29-41.

Houssiau, Albert, 'La liturgie comme manifestation du temps de Dieu dans le temps des hommes', in Rituels: Mélanges offertes au Père Gy O.P., ed. by Paul de Clerck and Eric Palazzo (Paris: Éditions du Cerf, 1990), pp. 327-37.

Howells, Richard, 'Heroes, Saints and Celebrities: The Photograph as Holy Relic', Celebrity Studies, 2.2 (2011), 112-30.

Huffer, Ian, “'What Interest does a Fat Stallone Have for an Action Fan?”: Male Film Audiences and the Structuring of Stardom', in Contemporary Hollywood Stardom, ed. by Thomas Austin and Martin Barker (London: Arnold, 2003), pp. 155-66.

Hussain, Zaheer, and Mark D. Griffiths, 'Gender Swapping and Socializing in Cyberspace: An Exploratory Study', CyberPsychology \& Behavior, 11.1 (2008), 47-53.

Hutchings, Tim, 'Creating Church Online: An Ethnographic Study of Five Internet-Based Christian Communities' (unpublished doctoral thesis, Durham University, 2010).

—, 'The Politics of Familiarity: Visual, Liturgical and Organisational Conformity in the Online Church', Online - Heidelberg Journal of Religions on the Internet, 4.1 (2010) 63-86, http:// nbn-resolving.de/urn:nbn:de:bsz:16-rel-93850 [accessed 24 August 2016].

'icon, n.', in Oxford English Dictionary Online (Oxford: Oxford University Press, 200o-present), http://www.oed.com/ [accessed 4 August 2016].

Immonen, Visa, and Jussi-Pekka Taavitsainen, 'Finger of a Saint, Thumb of a Priest: Medieval Relics in the Diocese of Turku, and the Archaeology of Lived Bodies', Scripta instituti donneriani aboensis, 23 (2011), 141-73.

Ingram, Matthew, 'Why Kim Kardashian Is Almost as Smart About Social Media as Donald Trump', Fortune [Online] (18 July 2016), http://fortune.com/2016/07/18/kardashian-donaldtrump/ [accessed 19 July 2016].

Innes-Parker, Catherine, 'Sexual Violence and the Female Reader: Symbolic "Rape” in the Saints' Lives of the Katherine Group', Women's Studies, 24 (1995), 205-17.

Jansen, Sharon L., 'Margery Kempe Tells Her Story', The Monstrous Regiment of Women (7 October 2015), http://www.monstrousregimentofwomen.com/2015/10/margery-kempetells-her-story.html [accessed 7 June 2015].

Jay, Martin, Downcast Eyes: The Denigration of Vision in Twentieth-Century French Thought (Berkeley: University of California Press, 1994).

—, 'The Rise of Hermeneutics and the Crisis of Ocularcentrism', Poetics Today, 9.2 (1988), 307-26. Jeay, Madeleine, and Kathleen E. Garay, “'To Promote God's Praise and Her Neighbour's Salvation": Strategies of Authorship and Readership Among Mystic Women in the Later Middle Ages', in Women Writing Back/Writing Women Back: Transnational Perspectives from the Late Middle Ages to the Dawn of the Modern Era, ed. by Anke Gilleir, Alicia C. Montoya, and Suzanna van Dijk (Leiden: Brill, 2010), pp. 23-50.

Jefferies, Diana, and Debbie Horsfall, 'Forged By Fire: Margery Kempe's Account of Postnatal Psychosis', Literature and Medicine, 32.2 (2014), 348-64.

Jenkins, Henry, 'Afterword: The Future of Fandom', in Fandom: Identities and Communities in a Mediated World, ed. by Jonathan Gray, Cornel Sandvoss, and C. Lee Harrington (New York: New York University Press, 2007), pp. 357-64.

-, Convergence Culture: Where Old and New Media Collide (New York: New York University Press, 2006).

—,Fans, Bloggers, and Gamers: Exploring Participatory Culture (New York: New York University Press, 2006). 
—, 'Panorama historique des études de fans', trans. by Mélanie Bourdaa, Revue française des sciences de l'information et de la communication, 7 (2015), https://rfsic.revues.org/1645 [accessed 22 March 2016].

—, 'Star Trek Rerun, Reread, Rewritten: Fan Writing as Textual Poaching', in Close Encounters: Film, Feminism and Science Fiction, ed. by Constance Penley, Elisabeth Lyon, and Lynn Spigel (Minneapolis: University of Minnesota Press, 1991), pp. 171-202 (first publ. in Critical Studies in Mass Communication, 5.2 (1988), 85-107).

—, Textual Poaching: Television Fans and Participatory Culture (New York: Routledge, 1992).

Jenkins, Henry, and TWC Editor, 'Interview with Henry Jenkins', Transformative Works and Cultures, 1 (2008), http://journal.transformativeworks.org/index.php/twc/article/view/61 [accessed 22 March 2016].

Jensen, Elizabeth, 'What's All The “Kommotion” About Kim Kardashian On "Wait Wait”?', NPR Ombudsman (17June 2015), http://www.npr.org/sections/ombudsman/2015/06/17/415203751/ what-s-all-the-kommotion-about-kim-kardashian-west-on-wait-wait [accessed 20 July 2016].

Jensen, Richard Bach, 'The United States, International Policing, and the War against Anarchist Terrorism, 1900-1914', in Terrorism: Critical Concepts in Political Science, ed. by David C. Rapoport, 4 vols. (New York: Routledge, 2006), I, pp. 369-400.

Jiménez, Manuel González, 'Beguinos en Castilla: nota sobre un documento sevillano', Historia. Instituciones. Documentos, 4 (1977), 109-14.

Johnson, Phylis, and Donald Pettit, Machinima: The Art and Practice of Virtual Filmmaking (Jefferson, NC: McFarland, 2012).

Johnson, David, and Megan McCluskey, 'See the Most Googled Person in Each Country in 2016', Time.com (22 December 2016), http://time.com/4604267/most-googled-person-2016-donaldtrump/ [accessed 30 August 2017].

Josh, April 28, 2016 Worship (18 April 2016). Second Life Notecard.

Kandiyoti, Deniz, 'Bargaining with Patriarchy', Gender and Society, 2.3 (1988), 274-90.

Kaplan, Louis, 'Where the Paranoid Meets the Paranormal: Speculations on Spirit Photography', ArtJournal, 62.3 (2003) 19-29.

Kardashian, Kourtney, Kim Kardashian, and Khloé Kardashian, Dollhouse (New York: William Morrow, 2011).

—, Kardashian Konfidential (New York: St. Martin's Press, 2010).

Kardashian West, Kim, '@KimKardashian [Facebook Feed]', Facebook, ([n.d.]), https://www. facebook.com/KimKardashian/ [accessed 9 April 2017].

—, '@kimkardashian [Instagram Feed]', Instagram, ([n.d.]), https://www.instagram.com/ kimkardashian/?hl=en [accessed 9 April 2017].

—, '@kimkardashian [Twitter Feed]', Twitter, ([n.d.]), https://twitter.com/KimKardashian [accessed 9 April 2017].

—, 'However, I thought it was important to share this story through my eyes \& not in an interview where my own words could be twisted', tweet by @kimkardashian, (19 March 2017), https:// twitter.com/KimKardashian/status/843528717531996160 [accessed 31 March 2017].

—, Selfish (New York: Rizzoli, 2015).

—, 'Tonight's episode is going to be very tough for me', tweet by @kimkardashian, (19 March 2017), https://twitter.com/KimKardashian/status/843528449507569664 [accessed 31 March 2017].

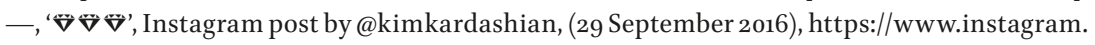
com/p/BK86_2ijyaS/?hl=en [accessed 31 March 3017].

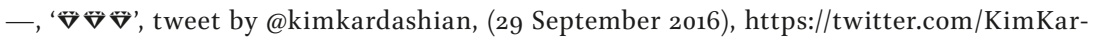
dashian/status/78159052365621248o/photo/1 [accessed 31 March 2017]. 
Karras, Ruth Mazo, Sexuality in Medieval Europe:Doing Unto Others (New York: Routledge, 2005). Kay, Sarah, Courtly Contradictions: The Emergence of the Literary Object in the Twelfth Century (Stanford: Stanford University Press, 2001).

—, 'Flayed Skin as objet a: Representation of Materiality in Guillaume de Delguileville's Pèlerinage de vie humaine', in Medieval Fabrication:Dress, Textiles, Cloth Work, and Other Cultural Imaginings, ed. by E. Jane Burns (New York: Palgrave Macmilllan, 2004), pp. 193-205.

—, 'Legible Skins: Animals and the Ethics of Medieval Reading', postmedieval, 2 (2011), 13-32.

—, 'Original Skin: Flaying, Reading and Thinking in the Legend of Saint Bartholomew and Other Works', Journal of Medieval and Early Modern Studies, 36.1 (2006), 35-74.

Keitt, Andrew W., Inventing the Sacred: Imposture, Inquisition, and the Boundaries of the Supernatural in Golden Age Spain (Leiden: Brill, 2005).

Kennel, Sarah, Diane Waggoner, and Alice Carver-Kubik, In the Darkroom: An Illustrated Guide to Photographic Processes Before the Digital Age (Washington, DC: Thames and Hudson, 2010).

Kienzle, Beverly Mayne, 'Preaching the Cross: Liturgy and Crusade Propaganda', Medieval Sermon Studies, 53 (2009), 11-32.

King, Barry, 'Articulating Digital Stardom', Celebrity Studies, 2.3 (2011), 247-62.

King, Margot H., 'Introduction', in MOS, pp. 35-38.

—, 'The Sacramental Witness of Christina Mirabilis: The Mystic Growth of a Fool for Christ's Sake', in Medieval Religious Women. Volume Two: Peaceweavers, ed. by Lillian Thomas Shank and John A. Nichols (Kalamazoo, MI: Cistercian Publications, 1987), pp. 145-64.

King, Margot H., and Ludo Jongen, 'The Holy Women of Liège: A Bibliography', (2007), http:// monasticmatrix.org/commentaria/holy-women-li\% $3 \%$ A8ge-bibliography [accessed 15 September 2016].

Kirst, Seamus, 'The Kardashian's Social Media Influence', Forbes [Online] (17 December 2015), http://www.forbes.com/sites/seamuskirst/2015/12/17/the-kardashians-social-mediainfluence/ [accessed 19 July 2016].

Kleinberg, Aviad M., 'A Thirteenth-Century Struggle over Custody: The Case of Catherine of Parc-aux-Dames', Bulletin of Medieval Canon Law n.s. 20 (1990), 51-67.

Kripal, Jeffrey J., Mutants and Mystics: Science Fiction, Superhero Comics, and the Paranormal (Chicago: University of Chicago Press, 2011).

-, Roads of Excess, Palaces of Wisdom: Eroticism and Reflexivity in the Study of Mysticism (Chicago: University of Chicago Press, 2001).

- , 'Secrets in the Seats: The Erotic, the Paranormal, and the Free Spirit', in Teaching Mysticism, ed. by William B. Parsons (Oxford: Oxford University Press, 2011), pp. 288-303.

Kuhn, Annette, and Guy Westwell, 'Film Preservation', in Oxford Dictionary of Film Studies (Oxford: Oxford University Press, 2012), pp. 171-72.

Kurtz, Patricia Deery, 'Mary of Oignies, Christine the Marvelous, and Medieval Heresy', Mystics Quarterly, 14.4 (1988), 186-96.

Kuryluk, Ewa, Veronica and Her Cloth: History, Symbolism, and Structure of a "True" Image (Cambridge, MA: Basil Blackwell, 1991).

Lambert, Malcolm, Medieval Heresy: Popular Movements from the Gregorian Reform to the Reformation, 2nd edn (Oxford: Blackwell, 1997).

Lang, Cady, 'These Were the Top 10 Most “Googled” Selfies of 2016', Time.com (14 December 2016), http://time.com/4600104/most-googled-selfies-of-2016/ [accessed 30 August 2017].

Larrington, Carolyne, 'The Candlemas Vision and Marie d'Oignies's Role in its Dissemination', in NTFS, pp. $195^{-214}$. 
Latour, Bruno, We Have Never Been Modern, trans. by Catherine Porter (Cambridge, MA: Harvard University Press, 1993).

Lauwers, Michel, 'Expérience béguinale et récit hagiographique', Journal des savants, 1-2 (1989), 61-103.

Lauwrens, Jenni, 'Can You See What I Mean?: An Exploration of the Limits of Vision in AntiOcularcentric Contemporary Art', De Arte, 85 (2012), 26-41.

Le Crosnier, Hervé, 'Culture, éducation, émancipation: les enjeux du numérique', in Culturenum: jeunesse, culture et éducation dans la vague numérique, ed. by Hervé Le Crosnier (Caen: C\&F éditions, 2013), pp. 177-206.

Le Goff, Jacques, The Birth of Purgatory, trans. by Arthur Goldhammer (Chicago: University of Chicago Press, 1984).

—, In Search of Sacred Time: Jacobus de Voragine and The Golden Legend, trans. by Lydia G. Cochrane (Princeton: Princeton University Press, 2014).

—, The Medieval Imagination, trans. by Arthur Goldhammer (Chicago: University of Chicago Press, 1988).

—, Time, Work, and Culture in the Middle Ages, trans. by Arthur Goldhammer (Chicago: Chicago University Press, 1980).

Lerner, Robert E., The Heresy of the Free Spirit in the Later Middle Ages (Berkeley: University of California Press, 1972).

Lewis, Katherine J., 'Margery Kempe and Saint Making in Later Medieval England', in A Companion to The Book of Margery Kempe, ed. by John Arnold and Katherine J. Lewis (Woodbridge, UK: Brewer, 2004), pp. 195-215.

Linares, Kevin, Kaveri Subrahmanyam, Roy Cheng, and Shu-Sha Angie Guan, 'A Second Life Within Second Life: Are Virtual World Users Creating New Selves and New Lives?', International Journal of Cyber Behavior, Psychology and Learning, 1.3 (2011), 50-71.

Lindberg, David C., 'Alhazen's Theory of Vision and its Reception in the West', Isis, 58.3 (1967), 321-41.

—, 'Medieval Science and its Religious Context', Osiris, 10 (1995), 60-79.

—, Theories of Vision from al-Kindi to Kepler (Chicago: University of Chicago Press, 1976).

Linden Lab, "Church" in Places', Second Life Search, ([n.d.]), http://search.secondlife.com/?query_ term=Church\&collection_chosen=places\&isLef tColOpen=True [accessed 1 August 2016].

—, 'Homepage', Second Life, ([n.d.]), http://secondlife.com/ [accessed 8 August 2016].

—, 'Premium Membership', Second Life, ([n.d.]), https://secondlife.com/premium/ [accessed 30 August 2017].

—, 'Religious Places', Second Life Wiki, (4 January 2016), http://wiki.secondlife.com/wiki/ Religious_Places [accessed 1 August 2016].

—, 'User Statistics', Second Life, ([n.d.]), http://secondlife.com/xmlhttp/secondlife.php [accessed 7 April 2017].

—, 'What Does “SLT” Stand For?', Second Life Wiki, (2011), http://wiki.secondlife.com/wiki/ What_does_\%22SLT\%22_stand_for\%3F [accessed 10 September 2012].

Lipton, Sara, "The Sweet Lean of His Head": Writing about Looking at the Crucifix in the High Middle Ages', Speculum, 80 (2005), 1172-1208.

Loiperdinger, Martin, ed., Celluloid Goes Digital:Historical-Critical Editions of Films on DVD and the Internet. Proceedings of the First International Trier Conference on Film and New Media, October 2002 (Trier: Wissenschaftlicher Verlag, 2003).

Lorenz, Taylor, 'Virtual Reality Is Full of Assholes Who Sexually Harass Me. Here's Why I Keep Going Back', Mic (26 May 2016), https://mic.com/articles/14447o/sexual-harassment-invirtual-reality\#.4Tm4M5wtr [accessed 15 May 2017].

Lowood, Henry, and Michael Nitsche, eds., The Machinima Reader (Cambridge, MA: MIT Press, 2011). 
Ma, Jean, 'Photography's Absent Times', in Still Moving: Between Cinema and Photography, ed. by Karen Beckman and Jean Ma (Durham: Duke University Press, 20o8), pp. 98-118.

Maiberg, Emanuel, 'Why Is “Second Life” Still a Thing?', Motherboard, (29 April 2016), https:// motherboard.vice.com/en_us/article/why-is-second-life-still-a-thing-gaming-virtual-reality [accessed 7 April 2017].

Malaby, Thomas M., Making Virtual Worlds: Linden Lab and Second Life (Ithaca, NY: Cornell University Press, 2009).

Maniura, Robert, 'Icon/Image', Material Religion, 7.1 (2011), 50-56.

Mannaerts, Pieter, 'An Exception to the Rule?: The Thirteenth-Century Cistercian Historia for Mary of Oignies', Journal of the Alamire Foundation, 2 (2010), 233-69.

Marks, Laura U., The Skin of the Film:Intercultural Cinema, Embodiment, and the Senses (Durham: Duke University Press, 1999).

-, Touch: Sensuous Theory and Multisensory Media (Minneapolis: University of Minnesota Press, 2002).

Markus, R. A., 'Living within Sight of the End', in Time in the Medieval World, ed. by Chris Humphrey and W. M Ormrod (York: York Medieval Press, 2001), pp. 23-34.

Marshall, P. David, 'The Promotion and Presentation of the Self: Celebrity as Marker of Presentational Media', Celebrity Studies, 1.1 (2010), 35-48.

Mazzonis, Querciolo, Spirituality, Gender, and the Selfin Renaissance Italy: Angela Mericiand the Company of St Ursula (1471-1540) (Washington, DC: Catholic University of America Press, 2007).

McAvoy, Liz Herbert, Authority and the Female Body in the Writings of Julian of Norwich and Margery Kempe (Cambridge, UK: Brewer, 2004).

McCluskey, Megan, 'See the Most Googled Person in Each Country in 2015', Time.com (22 December 2015), http://time.com/4157975/kim-kardashian-lionel-messi-most-googled-people/ [accessed 2o July 2016].

McDayter, Ghislaine, Byromania and the Birth of Celebrity Culture (Albany: SUNY Press, 2009).

McDonagh, Maitland, 'The Dark Knight: Review', TVGuide [Online], (n.d.), http://www.tvguide. com/movies/dark-knight/review/290942 [accessed 8 April 2017].

McDonnell, Ernest W., The Beguines and Beghards in Medieval Culture, with Special Emphasis on the Belgian Scene (New Brunswick: Rutgers University Press, 1954).

-, 'Jacques de Vitry', in New Catholic Encyclopedia, 15 vols (Washington, DC: Catholic University of America, 2003), VII, pp. 693-94.

McGinn, Bernard, The Flowering of Mysticism: Men and Women in the New Mysticism (1200-1350) (New York: Crossroad, 1998).

McGuire, Brian Patrick, 'Monastic and Religious Orders, c. 1100-c.1350', in Christianity in Western Europe c. 1100-c. 1500, ed. by Miri Rubin and Walter Simons (Cambridge: Cambridge University Press, 2009), pp. 54-72.

—, 'Purgatory, the Communion of Saints, and Medieval Change', Viator, 20 (1989), 61-84.

McLaughlin, Megan, Consorting with Saints: Prayer for the Dead in Early Medieval France (Ithaca, NY: Cornell University Press, 1994).

Meadows, Mark Stephen, I, Avatar: The Culture and Consequences of Having a Second Life (Berkeley, CA: New Riders, 2008).

Mercadante, Linda A., Belief Without Borders: Inside the Minds of the Spiritual But Not Religious (Oxford: Oxford University Press, 2014).

Meyer, Birgit, 'Ghanaian Popular Cinema and the Magic in and of Film', in Magic and Modernity: Interfaces of Revelation and Concealment, ed. by Birgit Meyer and Peter Pels (Stanford: Stanford University Press, 2003), pp. 200-22.

—, 'Media and the Senses in the Making of Religious Experience: An Introduction', Material Religion, 4.2 (2008), 124-34. 
—, 'Medium', Material Religion, 7.1 (2011), 58-64.

Miller, Tanya Stabler, The Beguines of Medieval Paris: Gender, Patronage, and Spiritual Authority (Philadelphia: University of Pennsylvania Press, 2014).

—, 'What's in a Name?: Clerical Representations of Parisian Beguines (1200-1328)', Journal of Medieval History, 33 (2007), 60-87.

Mills, Robert, 'God's Time? Purgatory and Temporality in Late Medieval Art', in Time and Eternity: The Medieval Discourse, ed. by Gerhard Jaritz and Gerson Moreno-Riaño, International Medieval Research 9 (Turnhout: Brepols, 2003), pp. 477-500.

—, 'Havelok's Bare Life and the Significance of Skin', in Reading Skin in Medieval Literature and Culture, ed. by Katie L. Walter (New York: Palgrave Macmillan, 2013), pp. 57-80.

Mitchell, W.J.T., Iconology: Image, Text, Ideology (Chicago: University of Chicago Press, 1986).

—, Image Science (Chicago: University of Chicago Press, 2015).

-, What do Pictures Want?: The Lives and Loves of Images (Chicago: University of Chicago Press, 2005).

Montgomery, Scott B., 'Veronica's Veil', in Women and Gender in Medieval Europe: An Encyclopedia, ed. by Margaret Schaus (New York: Routledge, 2006), pp. 811-12.

More, Alison, 'According to Martha: Extra-Regular Religious Women and the Gospel Life', Franciscana, 10 (2008), 255-80.

—, 'Convergence, Conversion and, Transformation: Gender and Sanctity in Thirteenth-Century Liège', in $R M G$, pp. 33-48.

Morgan, Simon, 'Academic “Pseudo-Event” or a Useful Concept for Historians?', Cultural and Social History, 8.1 (2011), 95-114.

Morris, Bridget, 'Birgittines and Beguines in Medieval Sweden', in NTFS, pp. 159-75.

Morrison, Blake, Mary McCartney, Steve Pyke, Grayson Perry, Katie Mitchell, Sean O'Hagan, Jemima Kiss, Louise Wilson, and Adrian Searle, 'The Power of Photography: Time, Mortality, and Memory', The Guardian [Online] (19 May 2013), http://www.theguardian.com/artanddesign/interactive/2013/may/19/power- photography-time-mortality-memory [accessed 19 January 2016].

Muessig, Carolyn, 'Prophecy and Song: Teaching and Preaching by Medieval Women', in Women Preachers and Prophets through Two Millennia of Christianity, ed. by Beverly Mayne Kienzle and Pamela J. Walker (Berkeley: University of California Press, 1998), pp. 146-58.

Mulder-Bakker, Anneke B., 'General Introduction', in MOS, pp. 1-32.

—, 'Holy Laywomen and Their Biographers in the Thirteenth Century', in LSTC, pp. 1-42.

—, 'The Invention of Saintliness: Texts and Contexts', in The Invention of Saintliness, ed. by Anneke B. Mulder-Bakker (London: Routledge, 2002), pp. 3-23.

—, Lives of the Anchoresses: The Rise of the Urban Recluse in Medieval Europe (Philadelphia: University of Pennsylvania Press, 2005).

—, 'Two Women of Experience, Two Men of Letters, and the Book of Life', in Women and Experience in Later Medieval Writing:Reading the Book of Life, ed. by Anneke B. Mulder-Bakker and Liz Herbert McAvoy (New York: Palgrave Macmillan, 2009), pp. 83-101.

Müller, Jan-Dirk, 'Blinding Sight: Some Observations on German Epics of the Thirteenth Century', in Rethinking the Medieval Senses: Heritage, Fascinations, Frames, ed. by Stephen G. Nichols, Andreas Kablitz, and Alison Calhoun (Baltimore: Johns Hopkins University Press, 2008), pp. 206-17.

Mulvey, Laura, 'Afterthoughts on "Visual Pleasure and Narrative Cinema" Inspired by King Vidor's Duel in the Sun (1949)', in Feminist Film Theory: A Reader, ed. by Sue Thornham (New York: New York University Press, 1999), pp. 31-4o (first publ. in Framework, 15-17 (1981), 12-15).

—, Death 24x a Second: Stillness and the Moving Image (London: Reaktion Books, 2006). 
—, 'Visual Pleasure and Narrative Cinema', in Feminism and Film Theory, ed. by Constance Penley (New York: Routledge, 1988), pp. 57-68 (first publ. in Screen, 16.3 (1975), 6-18).

Mulvey, Laura, and Roberta Sassatelli, 'Interview with Laura Mulvey: Gender, Gaze and Technology in Film Culture', Theory, Culture \& Society, 28 (2011), 123-43.

Mumler, William H., The Personal Experiences of William H. Mumler in Spirit-Photography (Boston: Colby and Rich, 1875).

Musser, Charles, Before the Nickelodeon:Edwin S. Porter and the Edison Manufacturing Company (Berkeley: University of California Press, 1991).

Neaman, Judith S., 'Sight and Insight: Vision and the Mystics', Fourteenth-Century English Mystics Newsletter, $5 \cdot 3$ (1979), 27-43.

Nelson, Robert S., ed., Visuality Before and Beyond the Renaissance: Seeing as Others Saw (Cambridge: Cambridge University Press, 2000).

Neva, Prokofy, Sacred Places in Second Life (25 January 2009). Second Life Notecard.

Newhall, Beaumont 'Photography as a Branch of Art History', College Art Journal, 1.4 (1942) 86-90.

Newman, Barbara, 'Devout Women and Demoniacs in the World of Thomas of Cantimpré', in NTFS, pp. 35-6o.

—, 'Introduction', in TCCSL, pp. 3-51.

—, 'Introduction to The Life of Juliana of Cornillon', in LSTC, pp. 145-75.

- , 'Preface: Goswin of Villers and the Visionary Network', in $S M G$, pp. xxix-xlix.

-, "What Did It Mean to Say "I Saw"?: The Clash between Theory and Practice in Medieval Visionary Culture', Speculum, 80 (2005), 1-43.

Newman, Barbara, and Anneke B. Mulder-Bakker, 'Canon of Thirteenth-Centry Southern Netherlandish Saint's Lives', in LSTC, pp. 43-45.

Newman, Martha G., 'Crucified by the Virtues: Monks, Lay Brothers, and Women in ThirteenthCentury Cistercian Saints' Lives', in Gender and Difference in the Middle Ages, ed. by Sharon Farmer and Carol Braun Pasternack (Minneapolis: University of Minnesota Press, 2003), pp. 182-209.

Ng, Jenna, ed., Understanding Machinima: Essays on Filmmaking in Virtual Worlds (New York: Bloomsbury, 2013).

Nguyen, V. Henry T., Christian Identity in Corinth (Tübingen: Mohr Siebeck, 2008).

Nichols, Stephen G., "'The Pupil of Your Eye”: Vision, Language, and Poetry in Thirteenth-Century Paris', in Rethinking the Medieval Senses: Heritage, Fascinations, Frames, ed. by Stephen G. Nichols, Andreas Kablitz, and Alison Calhoun (Baltimore: Johns Hopkins University Press, 2008), pp. 286-307.

Nichols, Stephen G., Andreas Kablitz, and Alison Calhoun, eds., Rethinking the Medieval Senses: Heritage, Fascinations, Frames (Baltimore: Johns Hopkins University Press, 2008).

Nicholson, Helen J., The Crusades (Westport, CT: Greenwood Press, 2004).

Nickel, Douglas R., 'Talbot's Natural Magic', History of Photography, 26.2 (2002) 132-40.

Nino, Tateru, 'A Mystery!', Dwell on It: The Comic, (2010), http://dwellonit- comic.taterunino. net/archive/86 [accessed 8 August 2016].

Njus, Jesse, 'The Politics of Mysticism: Elisabeth of Spalbeek in Context', Church History, 77.2 (2008), 285-317.

Noble, David F., The Religion of Technology: The Divinity of Man and the Spirit of Invention (New York: Penguin, 1997 (repr. 1999)).

Novikova, Ze, St George Orthodox Church in SL ([n.d.]; received from author 16 April 2016). Second Life Notecard. 
Oakleaf, Meleth, 'Second Life's Pandora Na'vi Roleplay - Breathtaking Beauty and Lag', Alphaville Herald, (24 February 2010), http://alphavilleherald.com/2010/02/second-lifes-pandora-navibreathtaking-beauty-and-lag.html [accessed 8 August 2016].

Oestreicher, Jeannie, and Larry Warner, Imaginative Prayer for Youth Ministry: A Guide to Transforming Your Students' Spiritual Lives into Journey, Adventure, and Encounter (Grand Rapids, MI: Zondervan, 2006).

Ogden, Amy Victoria, 'The Centrality of Margins: Medieval French Genders and Genres Reconfigured', French Forum, 30.1 (2005), 1-23.

von der Osten-Sacken, Vera, Jakob von Vitrys »Vita Mariae Oigniacensis«: Zu Herkunft und Eigenart der ersten Beginen (Göttingen: Vandenhoeck \& Ruprecht, 2010).

Outka, Gene, Agape: An Ethical Analysis (New Haven: Yale University Press, 1972).

Papi, Anna Benvenuti, 'Mendicant Friars and Female Pinzochere in Tuscany: From Social Marginality to Models of Sanctity', in Women and Religion in Medieval and Renaissance Italy, ed. by Daniel Bornstein and Roberto Rusconi, trans. by Margery J. Schneider (Chicago: University of Chicago Press, 1996), pp. 84-103.

Parsons, William B., 'On Being Spiritual But Not Religious: Past, Present, Future(s)', Sacred Matters (16 June 2016), https://sacredmattersmagazine.com/on-being-spiritual-but-notreligious-past-present-future/ [accessed 2 May 2017].

Pavés, Ken, You Are Beautiful: A Beauty Guide for Real Women (New York: Sterling, 2013).

Pearce, Celia, Communities of Play: Emergent Cultures in Multiplayer Games and Virtual Worlds (Cambridge, MA: MIT Press, 2009).

Pelikan, Jaroslav, The Christian Tradition: A History of the Development of Doctrine, 5 vols (Chicago: University of Chicago Press, 1971-1989), III (1980).

Perarnau i Espelt, Josep, 'La Sentència del bisbe de València, Jaume d'Aragó, sobre e beguí Jaume Just i l'Hospital dels beguins (30 de juliol 1372)', Arxiu de Textos Catalans Antics, 27 (2008), 441-51.

Perez, Nissan N., 'Picturing Faith: Christian Representations in Photography' (unpublished doctoral thesis, University of Brighton, 2012), http://eprints.brighton.ac.uk/12141/1 /N.Perez. V1.pdf [accessed 16 January 2016].

-, Revelation: Representations of Christ in Photography (London and Jerusalem: Merrell and The Israel Museum, 2003).

Perk, Godelinde, “Birgitta Never Saw Me In This Way”: The Book of Margery Kempe as Competitive Fan Fiction', paper presented at the Gender and Status Competition in Premodern Societies Conference, Umeå Group for Premodern Studies, Umeå University, Sweden, 27 November 2015, https://www.academia.edu/18877279/_Birgitta_Never_Saw_Me_In_This_Way_The_ Book_of_Margery_Kempe_as_Competitive_Fan_Fiction [accessed 11 August 2016].

Petchesky, Barry, 'Woman Who Commissioned “Ghost” Photos With Dead Daughter Now Charged With Girl's Murder', Jezebel, (1 April 2016), http://jezebel.com/woman-who-commissionedghost-photos-with-dead-daughte-1768422467 [accessed 6 April 2017].

Peters, Edward, Heresy and Authority in Medieval Europe: Documents in Translation (Philadelphia: University of Pennsylvania Press, 1980).

Petroff, Elizabeth Alvida, Body and Soul: Essays on Medieval Women and Mysticism (Oxford: Oxford University Press, 1994).

—, Medieval Women's Visionary Literature (New York: Oxford University Press, 1986).

Peucker, Brigitte, The Material Image: Art and the Real in Film (Stanford: Stanford University Press, 2007).

Pheasant-Kelly, Frances, Fantasy Film Post 9/11 (New York: Palgrave Macmillan, 2013). 
Pomarico, Nicole, 'How Did Kim Kardashian \& Paris Hilton Meet? It Happened Long Before One of Them Employed the Other', Bustle (10 August 2015), http://www.bustle.com/ articles/102617-how-did-kim-kardashian-paris-hilton-meet-it-happened-long-before-oneof-them-employed [accessed 20 July 2016].

Pontifical Council for Social Communications, 'The Church and Internet', (22 February 2002), http://www.vatican.va/roman_curia/pontifical_councils/pccs/documents/rc_pc_pccs_ doc_20020228_church-internet_en.html [accessed 24 August 2016].

—, 'Ethics in Internet', (22 February 2002), http://www.vatican.va/roman_curia/pontifical_councils/pccs/documents/rc_pc_pccs_doc_20020228_ethics-internet_en.html [accessed 24 August 2016].

Pope, Stephen J., "'Equal Regard” versus "Special Relations"? Reaffirming the Inclusiveness of Agape', The Journal of Religion, 77.3 (1997), 353-79.

La Poste (French newspaper), 30 December 1895.

Pou y Martí, José María, Visionarios, beguinos y fraticelos catalanas (siglos XIII-XV) (Madrid, Spain: Colegio "Cardenal Cisneros", 1930 (repr. 1991)).

Prince, Stephen, 'Violence and Psychophysiology in Horror Cinema', in Horror Film and Psychoanalysis: Freud's Worst Nightmare, ed. by Steven Jay Schneider (Cambridge: Cambridge University Press, 2004), pp. 241-56.

Quigley, Christine, The Corpse: A History (Jefferson, NC: McFarland, 1996).

Quinn, Dave, 'Kim Kardashian West Admits Paris Robbers Targeted Her Because of Her Social Media', People [Online], (15 March 2017), http://people.com/tv/kim-kardashian-west-speaksout-paris-robbery-kuwtk-clip/ [accessed 31 March 2017].

Radde-Antweiler, Kerstin, “'Virtual Religion”: An Approach to a Religious and Ritual Topography of Second Life', Online, 3.1 (2008), 174-211.

Le Radical (French newspaper), 30 December 1895.

Raynaud, Dominique, 'La Faveur de l'optique à Oxford: discussion de trois thèses de sociologie de la connaissance sur l'explication de l'intérêt scientifique', LLULL, 24 (2001), 727-54.

Reinhard, CarrieLynn, 'Virtual Worlds, Technology and Cameron's Avatar', Virtual Worlds Research Project, (5 January 2010), http://worlds.ruc.dk/archives/180o [accessed 8 August 2016].

Robinson-Neal, Andreé, 'Enhancing the Spiritual Relationship: The Impact of Virtual Worship on the Real World Church Experience', Online, 3.1 (2008), 228-45.

Rojek, Chris, Celebrity (London: Reaktion, 2001).

—,Fame Attack: The Inflation of Celebrity and Its Consequences (London: Bloomsbury Academic, 2012).

Roukis-Stern, Christina, 'A Tale of Two Dioceses: Prologues as Letters in the Vitae Authored by Jacques de Vitry and Thomas de Cantimpré', in Negotiating Community and Difference in Medieval Europe: Gender, Power, Patronage, and the Authority of Religion in Latin Christendom, ed. by Katherine Allen Smith and Scott Wells (Leiden: Brill, 2009), pp. 33-47.

Round, Julie, and Bronwen Thomas, eds., Real Lives, Celebrity Stories: Narratives of Ordinary and Extraordinary People across Media (London: Bloomsbury Academic, 2014).

Rubin, Miri, Corpus Christi: The Eucharist in Late Medieval Culture (Cambridge: Cambridge University Press, 1991).

Rudy, Kathryn M., 'Dirty Books: Quantifying Patterns of Use in Medieval Manuscripts Using a Densitometer', Journal of Historians of Netherlandish Art, 2.1-2 (2010), http://www.jhna.org/ index.php/past-issues/volume-2-issue-1-2/129-dirty-books [accessed 21 December 2012]. 
—, 'Fragments of a Mental Journey to a Passion Park', in Tributes in Honor ofJames H. Marrow: Studies in Painting and Manuscript Illumination of the Late Middle Ages and Northern Renaissance, ed. by Jeffrey F. Hamburger and Anne S. Korteweg (Turnhout: Brepols, 2006), pp. 405-19. —, 'A Guide to Mental Pilgrimage: Paris, Bibliothèque de L'Arsenal Ms. 212', Zeitschrift für Kunstgeschichte, 63.4 (2000), 494-515.

—, 'Kissing Images, Unfurling Rolls, Measuring Wounds, Sewing Badges and Carrying Talismans: Considering Some Harley Manuscripts through the Physical Rituals they Reveal', Electronic British Library Journal (2011), 1-56. http://www.bl.uk/eblj/2011articles/pdf/ebljarticle52011. pdf [accessed 21 December 2012].

—, Piety in Pieces: How Medieval Readers Customized Their Manuscripts (Cambridge: Open Book Publishers, 2016).

-, Postcards on Parchment: The Social Lives of Medieval Books (New Haven: Yale University Press, 2015).

—, 'Sewing the Body of Christ: Eucharistic Wafer Souvenirs Stitched into Fifteenth-Century Manuscripts, primarily in the Netherlands', Journal of Historians of Netherlandish Art, 8.1 (2016) 41 para, http://www.jhna.org/index.php/vol-8-1-2016/327-rudy [accessed 18 February 2017].

-, Virtual Pilgrimages in the Convent: Imagining Jerusalem in the Late Middle Ages (Turnhout: Brepols, 2011).

—, 'Virtual Pilgrimage through the Jerusalem Cityscape', in Visual Constructs ofJerusalem, ed. by Bianca Kühnel, Galit Noga-Banai, and Hanna Vorholt (Turnhout: Brepols, 2014), pp. 381-93.

Rutherford, Anne, 'Cinema and Embodied Affect', Senses of Cinema, 25 (2003), http://sensesofcinema.com/2003/feature-articles/embodied_affect/ [accessed 20 December 2012].

Salih, Sarah, 'Introduction: Saints, Cults, and Lives in Late Medieval England', in A Companion to Middle English Hagiography, ed. by Sarah Salih (Cambridge: Brewer, 20o6), pp. 1-23.

Salzberg, Ana, 'The (Im)mortality of the Lived-Body: Marilyn Monroe's Screen Presence in The Misfits', e-pisteme, 2.1 (2009) 78-87, http://research.ncl.ac.uk/episteme/issues/issueo2/ contents/e-pisteme\%2oVol.2(1)\%20-\%20Ana\%2oSalzberg.pdf [accessed 27 September 2016 ].

Sanders, Theresa, Celluloid Saints: Images of Sanctity in Film (Macon, GA: Mercer University Press, 2002).

Sandor, Monica, 'Jacques de Vitry and the Spirituality of the Mulieres Sanctae', Vox Benedictina, 5.4 (1988), 289-312.

Sandvoss, Cornel, Fans: The Mirror of Consumption (Cambridge, UK: Polity, 2005).

Sautman, Francesca Canadé, 'Constructing Political Rule, Transforming Gender Scripts: Revisiting the Thirteenth-Century Rule of Joan and Margaret, Countesses of Flanders', in RMG, pp. 49-65.

Scheepsma, Wybren, The Limburg Sermons: Preaching in the Medieval Low Countries at the Turn of the Fourteenth Century (Leiden: Brill, 2008).

Schleif, Corine, 'Haptic Communities: Hands Joined in and on Manuscripts', in Manuscripts Changing Hands, ed. by Corine Schleif and Volker Schier (Wiesbaden, Germany: Harrassowitz Verlag, 2016), pp. 9-77.

—, 'Medieval Memorials: Sights and Sounds Embodied; Feelings, Fragrances and Flavors Remembered', Senses \& Society, 5.1 (2010), 73-92.

Schleiner, Anne-Marie, 'Does Lara Croft Wear Fake Polygons? Gender and Gender-Role Subversion in Computer Adventure Games ', Leonardo, 34-3 (2001), 221-26.

Schmitt, Jean-Claude, Ghosts in the Middle Ages: The Living and the Dead in Medieval Society, trans. by Teresa Lavender Fagan (Chicago: University of Chicago Press, 1998). 
Schmitt, Jean-Claude, and Société d'ethnologie française, Les Saints et les stars : le texte hagiographique dans la culture populaire (Paris: Beauchesne, 1983).

Schneckloth, Clint, Mediating Faith: Faith Transformation in a Trans-Media Era (Minneapolis: Fortress Press, 2014).

Sconce, Jeffrey, 'A Vacancy at the Paris Hilton', in Fandom: Identities and Communities in a Mediated World, ed. by Jonathan Gray, Cornel Sandvoss and C. Lee Harrington (New York: New York University Press, 2007), pp. 328-43.

Scribner, Robert W., Religion and Culture in Germany (1400-180o), ed. by Lyndal Roper, Studies in Medieval and Reformation Thought 81 (Leiden, Boston, and Köln: Brill, 2001).

Seal, Mark, 'The Inside Story of the Kim Kardashian Paris Hotel Heist', Vanity Fair [Online], (2016), http://www.vanityfair.com/style/2016/10/solving-kim-kardashian-west-paris-robbery [accessed 31 March 2017].

Second Pandora, 'Sims', ([n.d.]), http://secondpandora.wordpress.com/pandoran-sims/ [accessed 7 August 2016].

Sensi, Mario, 'Anchoresses and Penitents in Thirteenth- and Fourteenth-Century Umbria', in Women and Religion in Medieval and Renaissance Italy, ed. by Daniel Bornstein and Roberto Rusconi, trans. by MargeryJ. Schneider (Chicago: University of Chicago Press, 1996), pp. 56-83.

Shaviro, Steven, The Cinematic Body (Minneapolis: University of Minnesota Press, 1993).

Shepherd, Tyche, Second Life Grid Survey [Online database], http://www.gridsurvey.com/ [accessed 7 April 2017].

Shriram, Ketaki, and Raz Schwartz, 'All Are Welcome: Using VR Ethnography to Explore Behavior in Immersive Social Reality', in 2017 IEEE Virtual Reality (VR) Proceedings, ed. by Evan Suma Rosenberg, David M. Krum, Zachary Wartell, Betty Mohler, Sabarish V. Babu, Frank Steinicke and Victoria Interrante (Los Angeles: The Institute of Electrical and Electronics Engineers, 2017), 225-26, http://ieeexplore.ieee.org/document/7892258/ [accessed 16 May 2017].

Simon, Gérard, 'Roger Bacon et Kepler lecteurs d'Alhazen', Archives internationales d'histoire des sciences, 146.51 (2001), 38-54.

Simons, Walter, Cities of Ladies: Beguine Communities in the Medieval Low Countries, 1200-1565 (Philadelphia: University of Pennsylvania Press, 2001).

-, 'Holy Women of the Low Countries: A Survey', in Medieval Holy Women in the Christian Tradition c.110o-c.1500, ed. by Alistair Minnis and Rosalynn Voaden (Turnhout: Brepols, 2010), pp. 625-62.

—, 'On the Margins of Religious Life', in Christianity in Western Europe c. 1100-c. 1500, ed. by Walter Simons and Miri Rubin (Cambridge: Cambridge University Press, 2009), pp. 311-23.

Slide, Anthony, Nitrate Won't Wait: A History of Film Preservation in the United States (Jefferson, NC: McFarland, 1992).

Smet, Cornelis, and René Tiron, Histoire de la religion catholique en Brabant (Brussels: La Société Nationale pour la Propagation des Bons Livres, 1839).

Sobchack, Vivian Carol, The Address of the Eye:A Phenomenology of Film Experience (Princeton: Princeton University Press, 1992).

-, Carnal Thoughts: Embodiment and Moving Image Culture (Berkeley: University of California Press, 2004).

- 'Embodying Transcendence: On the Literal, The Material, and the Cinematic Sublime', Material Religion, 4.2 (2008), 194-203.

Sobecki, Sebastian, “The writyng of this tretys”: Margery Kempe's Son and the Authorship of Her Book', Studies in the Age of Chaucer, 37 (2015), 257-83.

Spadaro, Antonio, Cybergrace, trans. by Caroline Smart (Milan: 4ok, 2013). Kindle book.

-, Cybertheology: Thinking Christianity in the Era of the Internet, trans. by Maria Way (New York: Fordham University Press, 2014). 
—, "'Second Life": Il Desiderio di un'“Altra Vita", La Civiltà Cattolica, 3771-72 (2007), 266-78.

Spearing, A.C., 'Margery Kempe', in A Companion to Middle English Prose, ed. by A.S.G. Edwards (Cambridge, UK: D.S. Brewer, 2004), pp. 83-97.

Spencer-Hall, Alicia, 'Christ's Suppurating Wounds: Leprosy in the Vita of Alice of Schaerbeek (†1250)', in 'His brest tobrosten': Wounds and Wound Repair in Medieval Culture, ed. by Kelly DeVries and Larissa Tracy (Leiden: Brill, 2015), pp. 389-416.

—, 'The Horror of Orthodoxy: Christina Mirabilis, Thirteenth-Century "Zombie” Saint', postmedieval, 8.3 (2017) 352-75, https://doi.org/10.1057/pmed.2016.19 [accessed 30 August 2017].

—, 'Marie of Oignies, of Nivelles, or of Villers: The Multiple Textual Identities of a 13th-Century Holy Woman', Open Library of Humanities, 3.1 (2017) 11, 1-34, https://olh.openlibhums.org/ articles/10.16995/olh.88/ [accessed 18 May 2017].

—, 'Post-Mortem Projections: Medieval Mystical Resurrection and the Return of Tupac Shakur', MDCCCXXVI Opticonı826, 13 (2012) 56-71. http://ojs.lib.ucl.ac.uk/index.php/up/article/ view/1327 [accessed 26 September 2016].

—, 'Review of Living Saints of the Thirteenth Century: The Lives of Yvette, Anchoress of Huy; Juliana of Cornillon, Author of the Corpus Christi Feast; and Margaret the Lame, Anchoress of Magdeburg', ed. by Anneke B. Mulder-Bakker (Turnhout: Brepols, 2011), Marginalia, 17 (2013), 54-57, http://www.marginalia.co.uk/journal/17cambridge/17cambridge_reviews.pdf [acessed 27 September 2016].

—, 'Textual Authority and Symbolic Capital: Birgitta of Sweden's Inclusion in Walter Bower's Scotichronicon', in Across the Sólundarhaf: Connections between Scotland and the Nordic World. Selected Papers from the Inaugural St. Magnus Conference 2011, ed. by Andrew Jennings and Alexandra Sanmark (=Journal of the North Atlantic, Special Volume 4 (2013)), pp. 107-19, http://www.eaglehill.us/JONAonline/articles/JONA-Sp-4/20-Spencer-Hall.shtml [accessed 27 September 2016].

Staley, Lynn, 'Introduction', in $M K B$, pp. 1-16.

—, Margery Kempe's Dissenting Fictions (University Park: Pennsylvania State University Press, 1994).

Starkey, Kathryn, 'Visual Culture and the German Middle Ages', in Visual Culture and the German Middle Ages, ed. by Kathryn Starkey and Horst Wenzel (New York: Palgrave Macmillan, 2005), pp. 1-12.

Starkey, Kathryn, and Horst Wenzel, eds., Visual Culture and the German Middle Ages (Basingstoke, UK: Palgrave Macmillan, 2005).

Stefanone, Michael A., Derek Lackaff, and Devan Rosen, 'We're All Stars Now: Reality Television, Web 2.0, and Mediated Identities', in HT 'o8: Proceedings of the Nineteenth ACM Conference on Hypertext and Hypermedia, ed. by Peter Brusilovsky and Hugh Davis (New York: ACM, 2008), pp. 107-12.

Stevens, Dana, 'No Joke: The Dark Knight, Reviewed', Slate (2008), http://www.slate.com/articles/ arts/movies/2008/07/no_joke.html [accessed 8 April 2017].

Stewart, Garrett, Between Film and Screen: Modernism's Photo Synthesis (Chicago: University of Chicago Press, 1999).

Stoner, Abby, 'Sisters Between: Gender and the Medieval Beguines', Ex Post Facto, 4.2 (1995), http://userwww.sfsu.edu/epf/journal_archive/volume_IV,_no._2_-_sp._1995/stoner_a.pdf \ [accessed 23 April 2014].

Strieber, Whitley, and Jeffrey J. Kripal, The Super Natural: A New Vision of the Unexplained (New York: Penguin, 2016).

Sudyam, Mary, 'Bringing Heaven down to Earth: Beguine Constructions of Heaven', in Envisaging Heaven in the Middle ages, ed. by Carolyn Muessig and Ad Putter (London: Routledge, 2007), pp. 91-107. 
Sunny Jo, 'One More Time Tribute Photos', Sunny Jo Photography, (n.d.), http://sunnyjophotography.com/one-more-time-tribute-photos/one-more-time-tribute-photos [accessed 6 April 2017].

Sutton, Damian, Photography, Cinema, Memory: The Crystal Image of Time (Minneapolis: University of Minnesota Press, 2009).

Sweetman, Robert, 'Thomas of Cantimpré, Mulieres Religiosae, and Purgatorial Piety: Hagiographical Vitae and the Beguine 'Voice", in A Distinct Voice: Medieval Studies in Honor of Leonard E. Boyle, O.P, ed. by Jacqueline Brown, William P. Stoneman and Leonard E. Boyle (Notre Dame: University of Notre Dame Press, 1997), pp. 6o6-28.

Szerszynski, Bronislaw, Nature, Technology and the Sacred (Oxford: Blackwell Publishing, 2005).

Talbot, William Henry Fox, 'Some Account of the Art of Photogenic Drawing, or, The Process by Which Natural Objects May Be Made to Delineate Themselves without the Aid of the Artist's Pencil', in Photography, Essays and Images: Illustrated Readings in the History of Photography, ed. by Beaumont Newhall (New York: Museum of Modern Art, 1980), pp. 23- 32 (first publ. as individual work (London: R. and E.J. Taylor, 1839)).

Teasdale, Matthew D., Sarah Fiddyment, Jiří Vnouček, Valeria Mattiangeli, Camilla Speller, Annelise Binois, Martin Carver, Catherine Dand, Timothy P. Newfield, Christopher C. Webb, Daniel G. Bradley, and Matthew J. Collins, 'The York Gospels: A One Thousand Year Biological Palimpsest', bioRxiv preprint (24 July 2017) 1-15 http://www.biorxiv.org/content/ early/2017/07/24/146324 [accessed 19 August 2017]

Teeman, Tim, 'The Dark Knight: the first review', The Times [Online], (15July 2008), https://www. thetimes.co.uk/article/the-dark-knight-the-first-review-r8tgpb7rs6z [accessed 8 April 2017].

Tillyard, Stella, 'Celebrity in 18th-Century London', History Today, 55.6 (2005), 20-27.

Tolhurst, Fiona, 'Julian of Norwich and Margery Kempe as Contemporary Cult Figures', in Medieval Afterlives in Contemporary Culture, ed. by Gail Ashton (London: Bloomsbury, 2015), pp. 187-99.

Toro, Eduard Vives, 'Heterdoxia franciscana en las tierras de ponent catalanas y en Aragón', in Relacions històriques entre Aragó i Catalunya. Visions interdisciplinars. Relaciones históricas entre Aragóny Cataluña. Visiones interdisciplinares., ed. by Francesc Closa and Josep Manuel Martínez (Zaragoza and Lleida, Spain: Prensas de la Universidad de Zaragoza; Edicions de la Universitat de Lleida, 2004), pp. 171-94.

Turkle, Sherry, Alone Together: Why We Expect More from Technology and Less from Each Other (New York: Basic Books, 2011).

Turner, Graeme, 'Approaching Celebrity Studies', Celebrity Studies, 1.1 (2010), 11-20.

Urriah, Nalates, 'Second Life News Week 2 - \#2', Nalates' Things \& Stuff: Second Life and Virtual Worlds (17 January 2016), http://blog.nalates.net/2016/o1/17/second-life-news-week-2-2/ [accessed 22 August 2016].

Usai, Paolo Cherchi, The Death of Cinema: History, Cultural Memory, and the Digital Dark Age (London: BFI, 2001).

Vansteenkiste, J. C., 'Thomas of Cantimpré', in New Catholic Encyclopedia, 15 vols (Washington, DC: Catholic University of America, 2003), XIV, pp. 32-33.

Vauchez, André, 'Prosélytisme et action antihéretique en milieu féminin au XIIIe siècle: la Vie de Marie d'Oignies (1213) par Jacques de Vitry', Problèmes d'histoire du christianisme, 17 (1987), 95-110.

—, Sainthood in the Later Middle Ages, trans. by Jean Birrell (Cambridge: Cambridge University Press, 1997). 
Vela, Agustín Rubio, and Mateu Rodrigo Lizondo, 'Els beguins de València en el segle XIV. La seua casa-hospital i els seus llibres', in Miscel-lània Sanchis Guarner, ed. by Antoni Ferrando, 3 vols (Valencia and Barcelona, Spain: Universitat de València and Publicacions de l'Abadia de Montserrat, 1992), III, pp. 185-228.

Verrips, Jojada, 'Offending Art and the Sense of Touch', Material Religion, 4.2 (2008), 204-25.

Voaden, Rosalynn, God's Words, Women's Voices: The Discernment of Spirits in the Writing of Late-Medieval Women Visionaries (Woodbridge, UK: Boydell and Brewer, 1999).

Vollmer, Ulrike, Seeing Film and Reading Feminist Theology: A Dialogue (New York: Palgrave Macmillan, 2007).

Voss, Christiane, 'Film Experience and the Formation of Illusion: The Spectator as "Surrogate Body" for the Cinema', Cinema Journal, 50.4 (2011), 136-50.

Voyager, Daniel, 'Looking at the Second Life Grid Statistics for Q1 2017 \& Sansar Opening Date TBC', Daniel Voyager's Blog (3 April 2017), https://danielvoyager.wordpress.com/2017/04/o3/ looking-at-second-life-grid-statistics-during-q1-2017/ [accessed 7 April 2017].

Wagner, Rachel, 'Our Lady of Persistent Liminality: Virtual Church, Cyberspace, and Second Life', in God in the Details: American Religion in Popular Culture, ed. by Eric Michael Mazur and Kate McCarthy (London: Routledge, 2011), pp. 271-9o.

Walls, Jerry L., Purgatory: The Logic of Total Transformation (Oxford: Oxford University Press, 2012).

Washington Evening Star (American newspaper), 9 April 1908.

Watson, Nicholas, 'Desire for the Past', Studies in the Age of Chaucer, 21 (1999), 59-97.

-, 'The Making of The Book of Margery Kempe', in Voices in Dialogue: Reading Women in the Middle Ages, ed. by Linda Olson and Kathryn Kerby-Fulton (Notre Dame: University of Notre Dame Press, 2005), pp. 395-427.

—, 'The Phantasmal Past: Time, History, and the Recombinative Imagination', Studies in the Age of Chaucer, 32 (2010), 1-37.

'Ways To Cope With The Depression Of The Dream Of Pandora Being Intangible', AVATAR Forums, (2009), http://www.avatar-forums.com/showthread.php?43-Ways-to-cope-withthe-depression-of-the-dream-of-Pandora-being-intangible/ [accessed 6 June 2014].

Weisl, Angela Jane, 'Confession, Contrition, and the Rhetoric of Tears: Medievalism and Reality Television', in Medieval Afterlives in Popular Culture, ed. by Gail Ashton and Daniel T. Kline (New York: Palgrave Macmillan, 2012), pp. 129-43.

Weiß, Bardo, Die deutschen Mystikerinnen und ihr Gottesbild, 3 vols (Paderborn, Germany: Ferdinand Schöningh, 2004).

Wertheim, Margaret, The Pearly Gates of Cyberspace: A History of Space from Dante to the Internet (London: Virago, 1999).

Westervelt, Amy, 'Will Virtual Reality Be Just Another Way to Objectify Women?', Elle (22 June 2016), http://www.elle.com/culture/a37146/will-virtual-reality-just-be-another-way-toobjectify-women/ [accessed 15 May 2017].

White Jr, Lynn, Medieval Religion and Technology: Collected Essays (Berkeley: University of California Press, 1978).

Wiethaus, Ulrike, 'The Death Song of Marie d'Oignies: Mystical Sounds and Hagiographical Politics in Medieval Lorraine', in The Texture of Society: Medieval Women in the Southern Low Countries, ed. by Ellen E. Kittell and Mary A. Suydam (New York: Palgrave Macmillan, 2004), pp. 153-79.

Williams, Linda, 'Film Bodies: Gender, Genre, and Excess', Film Quarterly, 44.4 (1991), 2-13.

Williamson, Milly, 'Female Celebrities and the Media: The Gendered Denigration of the "Ordinary" Celebrity', Celebrity Studies, 1.1 (2010), 118-20. 
Windeatt, Barry, 'Introduction', in MKBEng, pp. 9-28.

—, 'Introduction', in The Book of Margery Kempe: Annotated Edition, ed. by Barry Windeatt (Cambridge, UK: D.S. Brewer, 2004), pp. 1-35.

Wogan-Browne, Jocelyn, and Marie-Elisabeth Henneau, 'Liège, the Medieval "Woman Question", and the Question of Medieval Women', in NTFS, pp. 1-32.

Wojcik, Daniel, 'Spirits, Apparitions, and Traditions of Supernatural Photography', Visual Resources, 25.1-2 (2009) 109-36.

Wong, Julia Carrie, 'Sexual Harassment in Virtual Reality Feels All Too Real - "It’s Creepy Beyond Creepy"', The Guardian (26 October 2016), https://www.theguardian.com/technology/2016/ oct/26/virtual-reality-sexual-harassment-online-groping-quivr [accessed 15 May 2017].

Wood, Helen, 'From Media to Identity to Mediated Identity', in The SAGE Handbook of Identities, ed. by Margaret Wetherell and Chandra Talpade Mohanty (London: SAGE, 2010), pp. 258-76.

Wright, Benjamin A., 'Women, Heresy, and Crusade: Toward a Context for Jacques de Vitry's Relationship to the Early Beguines', in A Mirror for Medieval and Early Modern Studies: Selected Proceedings of the Newberry Center for Renaissance Studies 2012 Multidisciplinary Graduate Student Conference, ed. by Laura Aydelotte, Mary Channen Caldwell, Julia Finch, Anuradha Gobin, Kati Ihnat, Caryn O'Connell, Abigail Stahl and Jennifer Toms (Chicago: The Newberry Library, 2012), pp. 149-58.

Yee, Nicholas, 'The Norrathian Scrolls: A Study of EverQuest', Version 2.5 (May 2001) 1-76, http:// www.nickyee.com/report.pdf [accessed 22 August 2016]. Online .pdf report.

—, 'WoW Gender-Bending', The Daedalus Project: The Psychology of MMORPGs (28 July 2005), http://www.nickyee.com/daedalus/archives/oo1369.php [accessed 22 August 2016].

Yoshikawa, Naoë Kukita, Margery Kempe's Meditations: The Context of Medieval Devotional Literatures, Liturgy, and Iconography (Cardiff: University of Wales Press, 2007).

—, 'Mysticism and Medicine: Holy Communion in the Vita of Marie d'Oignies and the Book of Margery Kempe', Poetica, 72 (2009), 109-18.

Ziegler, Joanna E., 'Reality as Imitation: The Role of Religious Imagery Among the Beguines of the Low Countries', in Maps of Flesh and Light: The Religious Experience of Medieval Women Mystics, ed. by Ulrike Wiethaus (Syracuse: Syracuse University Press, 1993), pp. 112-26.

\section{Audiovisual Sources}

Avatar, dir. by James Cameron (20 ${ }^{\text {th }}$ Century Fox, 2009$)$, on DVD $\left(20^{\text {th }}\right.$ Century Fox Home Entertainment, 2010).

AVATAR Second life. Part 1, (YouTube video, 5:53: posted by Christophe Dupuy, uploaded on 1 May 2010), http://www.youtube.com/watch?v=djay_lRhCqk\&list=PL9BB $37 B_{106 C C D} \mathrm{~A}_{7} \mathrm{~A}$ [accessed 8 April 2017].

Azhar, Azeem, and Yuval Harari, 'Homo Deus: A Conversation Between Yuval Harari and Azhar Azeem'. Exponential View podcast, 53:36. 3 March 2017, https://soundcloud.com/ exponentialview/homo-deus-a-conversation-between-yuval-harari-and-azeem-azhar [accessed 21 March 2017].

Beauty and the Beast, dir. by Gary Trousdale and Kirk Wise (Buena Vista Pictures, 1991), on DVD (Buena Vista Home Entertainment, 2010). 
The Birth of A Baby Na'vi Second Life (Zet'ey baby girl), (YouTube video, 2:48: prod. by InWorld Films, posted by Suzie Anderton, uploaded on 6 June 2013), http://www.youtube.com/ watch?v=Da-TzOBpNc4 [accessed 8 April 2017].

The Dark Knight, dir. by Christopher Nolan (Warner Bros. Pictures, 2008), on DVD (Warner Home Video, 2008).

Displaced Person, dir. by Daniel Eisenberg (Daniel Eisenberg, 1981), on DVD (Video Data Bank, School of the Art Institute of Chicago, 2011). Short film only available in box-set Postwar: The Films of Daniel Eisenberg; DVD reference data relate to this collection.

The Drax Files: World Makers [Episode 13: Creations for Parkinson's], (YouTube video, 4:59: prod. and posted by Draxtor Despres, uploaded on 1 November 2013), https://www.youtube.com/ watch?v=nyiiWxNguGo [accessed 16 August 2016].

EverQuest, (MMORPG: developed and published by Sony Online Entertainment; released 16 March 1999).

Execution by Hanging, prod. by Mutoscope (1898).

Execution by Hanging, prod. by Mutoscope and Biograph (1905).

Execution of Czolgosz, with Panorama of Auburn Prison, dir. by Edwin S. Porter (Thomas A. Edison, 1901), available online in the Library of Congress, http://www.loc.gov/item/oo694362/ [accessed 21 January 2016].

The Execution of Mary Queen of Scots, dir. by Alfred Clark (Thomas A. Edison, 1895), available online in the Library of Congress, http://www.loc.gov/item/oo694120 [accessed 21 January 2016].

Fast and Furious 7, dir. by James Wan (Universal Pictures, 2015), on DVD (Universal Pictures, 2015).

Jessica Simpson: A Public Affair, executive produced by Rod Aissa and Matt Anderson, directed by Jennifer Morton (prod. by Music Television, 2006).

Kardashian West, Kim, and Kara Swisher, 'If My Naked Selfies Offend You, Don't Look at Them', Recode Decode, hosted by Kara Swisher. Recode.net podcast, 33:33. 6 June 2016, https://art19. com/shows/recode-decode/episodes/e4c2928e-6a25-43oc-b3e1- 874e558862b9 [accessed 2o July 2016].

—, 'Interview at Re/code's Code Mobile'. Recode.net online video, 30:17. 27 October 2014, http:// www.recode.net/2016/6/6/11864134/kim-kardashian-naked-selfies-podcast-kara-swisher [accessed 2o July 2016].

Keeping Up With the Kardashians, created by Ryan Seacrest and Eliot Goldberg (prod. by BunimMurray Productions and Ryan Seacrest Productions, 2007-present).

Kim Kardashian's Best Ugly Crying Moments, (YouTube video, 1:17: posted by Fun Trolly, uploaded 23 October 2013), https://www.youtube.com/watch?v=UAOUJ_xk7Wo [accessed 8 April 2017].

Kourtney \& Kim Take Miami (marketed as Kourtney \& Khloé Take Miami for first two seasons), created by Ryan Seacrest and Jonathan Murray (prod. by Bunim-Murray Productions and Ryan Seacrest Produtions, 2009-2013).

Kourtney \& Kim Take New York, created by Ryan Seacrest, Mary-Ellis Bunim, and Jonathan Murray (prod. by Bunim-Murray Productions and Ryan Seacrest Productions, 2011-2012).

The Misfits, dir. by John Huston (United Artists, 1961), on DVD (MGM Home Video, 2012).

Pesca, Mike, Amy Dickinson, Maz Jobrani, Peter Grosz, Bill Kurtis, and Kim Kardashian West, 'Not My Job: Kim Kardashian Gets Quizzed On Kim Jong Un', Wait, Wait...Don't Tell Me! radio show (10:48), National Public Radio, 13June 2015, http://www.npr.org/2015/06/13/413926893/ not-my-job-kim-kardashian-gets-quizzed-on-kim-jong-un [accessed 20 July 2016].

The Price of Beauty (also marketed as Jessica Simpson: The Price of Beauty), executive produced by Joe Simpson and Jessica Simpson, directed by Tony Croll (prod. by RDF USA, 2010). 
The Simple Life, created by Mary-Ellis Bunim and Jonathan Murray (prod. by 20 th Century Fox Television, Bunim-Murray Productions, 2003-2007).

SLAVATAR TO NA'VI(Escape To Pandora), (YouTube video, 9:43: posted by Ali Mishref, uploaded on 6 April 2010), http://www.youtube.com/watch?v=LmGmOrYHP74 [accessed 8 April 2017].

Star Trek franchise (various series), created by Gene Rodenberry (prod. by various, 1966-2005).

Too Young to Die - Heath Ledger, dir. by Dag Freyer (2012), season 1, episode 3 of Liebling der Götter (prod. by ARTE).

Toy Story, dir. by John Lasseter (Buena Vista Pictures, 1995), on DVD (Walt Disney Home Video, 2000).

World of Warcraft, (MMORPG: developed and published by Blizzard Entertainment; released 23 November 2004 in Australasia and North America, 11 February 2005 in Europe).

The X Factor franchise (various nation-specific series), created by Simon Cowell (prod. by Thames, FremantleMedia, and Syco Entertainment, 2004-present). 


\section{Index}

9/11 see terrorism

Abad-Santos, Alex 185

Abundus of Huy 54-55

academy, the $175,190-92$

and medievalism in the 1980 s $180-81$

and objectivity 191

and photography 104

fans in $190-92$

feminist approaches in 56

spectators in 44

Academy Awards, the 5o, 90, 163, 179

acafen 191

Acre 28, 150, 190

actors, film and television 89-91, 162-63, 165-66; see also celebrity; Ledger, Heath computer-mediated 199-200, 202 conflation with film character 98-100, 148 typecasting of 45

actuality films $79-80$

Adams, Douglas 212

Ad nostrum qui see Vienne, Council of

Aelred of Rievaulx 13n9

agape 14-16

agape-ic encounter 15-16, 19-20, 59, 60 and Sobchack, Vivian Carol 16-18 manuscript as agent of 54 spiritual valency of 18

Agnes, abbess of Aywières 35

Agnes of Montepulciano 78n54

Alchemy, Barbie 221-22

Alhazen (Ibn al-Haitham) 114-15

Alice of Schaerbeek 21-22, 33-34, 38-39, 102-03, 140-41, 219, 248

Alphabetum narrationum (An Alphabet of Tales) see Arnold of Liège

Altberg, Ebbe 196

Amat, Trigit 228-30

Amengol, Peter $78 \mathrm{n}_{54}$

anarchy 83,99

antinomianism 30

Antwerp 25

apostles, the 206; see also St. Peter; St. Paul

Apostles'Creed 205

Aquinas, Thomas 84

Aragon, Crown of $41 \mathrm{n} 148$

Aristotle 108n6, 113-14

Arnold of Liège $167,169-70$

Arnulf II of Ghistelles 22, 102-04

Arnulf of Villers 54, 55, 57-58

Ascension, Feast of 128-29

asceticism $34,44,57-58,80,82-83,86,96$, 165-66, 211, 222

Atkinson, Clarissa W. 147, 180

Augustine 142, 143 (Fig. 9)
Augustinian Order 28-29, 188n19o

Auslander, Philip 197-98

Australia 216, 224, 239

autobiography 168

autocorrect 178

Avatar 199-204

AVATAR Forums 201

avatar(s), online 13, 52, 62, 194-95, 198, 200, 202, 204, 207, 209, 214-22, 228-29, 242

and imitatio Christi 228-30

and offline body 216-17, 220-22, 228-29, 242

as authentic representation(s) 215, 217-20, 242

as digital soul 220

definition of 214-15

gender-swapping of $235-36$

in Avatar 199-200, 202

symbolic value of $218-20$

Avicenna 114

Aykroyd, Peter H. 49

Aywières, monastery 35, 37-38, 94, 212

Bacon, Roger 107-11, 113-17, 123-25, 141

Opus majus 109

Bale, Christian 98

ballet 49

Baker, Norma Jean see Monroe, Marilyn

Barthes, Roland and the 'punctum' 75,79

and the 'studium' 79

Bartholomew of Tienen 31

Bastida, Rebeca Sanmartín 41

Batchen, Geoffrey 104-05

Batman 90-91, 97-98, 100-101

Bazin, André 77

beatas 41; see also beguines

beatification 187

Beatrice of Nazareth 21-22, 31, 33, 37, 74-75, 118, 122-26, 129-30, 246-47

Beatrice, nun of Sint-Truiden 104-05

Beauty and the Beast 11, 14, 41-42

beguinages 27-29, 33-34, 53

beguines 22-30, 40-42, 154

as heretics 30,153

church of, in Sint-Truiden 244

clerical support for $28-30,153,156$

definition of $30-36,40$

institutionalized beguines 33-35, 53; see also beguinages

references to beguines in the corpus 31 use of term in modern scholarship 31-32

Belgium 28, 148n13

Bellour, Raymond 111

Benedictine Order 23, 40, 62

Berlioz, Jacques 165 
Bernard the Pentitent 54

Bethlehem 193

Bible, books of

Acts $84 \mathrm{n} 86,128$

I Corinthians 79, 84, 102

II Corinthians 84n86, 126, 219

Ezekiel 119

Exodus 124

Genesis 177

Hebrews $84 \mathrm{n} 86,124 \mathrm{n} 67$

Jeremiah $124 \mathrm{n} 67$

Job 102, 124n67

John $78 \mathrm{n} 58,121,136,215$

Luke $78 \mathrm{n}_{5} 8,126 \mathrm{n}_{73}, 136,243,250$

Mark 121, 243

Matthew 24, 95, 218, 243, $25^{\circ}$

Numbers 121

Philippians 84n86

Proverbs $124 \mathrm{n} 67$

Psalms 124n67, 233

Revelations $32 \mathrm{n} 77,78$

Romans 24, 84n86, 205

I Thessalonians $84 \mathrm{n} 86$

I Timothy 24

II Timothy $84 \mathrm{n} 86$

Biddick, Kathleen 56n188, 191n201, 245n13

Biernoff, Suzannah 108, 118

Bizoke 40; see also beguines

blogs, online $144,180,199$

blood 34, 99, 112, 118, 126, 130, 138n134, 213, 215, $221,223,226,243$

as stigmata 75,246

Bollandists, the 32,164

Bonum universale de apibus see Thomas of Cantimpré

book(s) of life

Christ as 138

hagiography as $32-33$

of modern women 254

visions of 206

Book of Margery Kempe see Kempe, Margery

Boniface VIII 244

Borland, Jennifer 139, 141-43

Brabant 150

Brabant-Liège 25, 29 (Fig. 4), 32, 37, 40-42, 52, $54,151,249,253$

Brown, Catherine 142-43, 253

Brown, Jennifer N. 31-32, 158

Bruges 25

Bruns, Axel 203

and 'produsage' 203-04, 240-41

Brussels 25, 140n141

Byers, Stephen Francis 238

Bynum, Caroline Walker 56, 214-15

Holy Feast and Holy Fast 191-92

Caesarius of Heisterbach 96, 138

Cambrai, diocese of 22, 28 (Fig. 3), 38

La Cambre, abbey 38-39, 219 camera, the

digital 70

film 15, 121-22, 200

in online virtual environments 203

in smart devices $5^{0}$

metaphorical, of patriarchy 182

of the mind 20

photographic $5^{2}$

Polaroid 70

Campbell, Emma 108, 110

canonization $33,105,187$

Canterbury 174

Cantimpré, abbey 29

capitalism $68,83,98$

Carozzi, Claude 251

Carpenter, Jennifer 36-37

Carruthers, Mary 93

Castile 41

Casey, Cheryl 195

Catharism see heresy

Catherine of Louvain 36-37

Catherine of Parc-aux-Dames see Catherine of Louvain

Catherine of Siena $78 \mathrm{n}_{54}$

Cawood, diocese of 169

Cazelles, Brigitte 220

celebrity $61,147-92,247$

and exceptionality $165-66$

and fans $61,149-50,154,15^{8-64}, 176$; see also fans

and hagiography $61,147-55,161,163-66$

and morality $153-54,165$; see also exempla

as mediatized existence $148,151-52,161-62$, $165^{-66,186,198}$

Classic Hollywood model of 51-52, 148-49, 162-63

costs and privileges of $51,155,165-66,247$

hierarchy of $163-64,175-76,186$

manufacture of $51-5^{2}, 149-50,158-59$, $162-63,174-79,181-87,198-99$

'normal' celebrity 198-99

self-production of 174-79, 181-87, 198-99

signification of $61,148,177$

Chang, Justin 98-99

Chee, Florence 213

Chronica majora see Matthew Paris

Christ 21, 24, 58, 65, 76, 84, 93, 96, 107, 153, 173, 188, 205, 217, 219-20, 223, 226-28, 230-31, 243-47, 249-50, 252; see also Eucharist, the; imitatio Christi; Passion, the; resurrection and communion of saints 205-07 as celebrity 177

as divine film 122, 127, 129, 130

as perfect and whole $121,127,205,230$

as projector 78

as screen 139

embodied in manuscript(s) $138-39,144$

images of see 'Face of Christ Superimposed On An Oak Leaf'; Veronica, icon 
in imaginative prayer 194

physicality of, in visions $75,118-19,121-22$, $126-27,136,215,230$

Second Coming of $73,84,93,95-96$

statues of 53,244

visions of $24,58,72,75-76,95,107,118-19$, 121, 126-30, 134, 136, 169, 176-77, 18o, 193, 206-07, 210, 215, 226-28, 233

Christians, non-denominational 209, 212, 214, $218,223,231$

Christina Mirabilis 21-22, 35, 37-39, 46n16o, 55, 78-83, 86-89, 93-97, 103-05, 161, 248, 251

Christina of Stommeln $46 \mathrm{nn}_{1} 6 \mathrm{o}$

Church, Anglican 208, 224

Church of England 180

Church, Episcopal 180, 236

Church of Jesus Christ of Latter-day Saints 218-19

Church, Methodist 224

Church, Orthodox 208

Church, Pentecostal 223

Church, Roman Catholic 153, 165, 195, 217, 220 ,

224,236

and communion of saints 205

and Eucharist online 223-24, 227, 238-39

control over mysticism 18-19, 76, 227, 231

control over time 93-94

need for holy women 43-44, 46-47, 69-70,

$82-83,121,132-33,15^{2-53}, 155,232,243$,

247-49

needed by holy women $24,51,240-41,243$,

$$
\text { 249-5o }
$$

cinema ; see also film; machinima; spectatorship and ecstasy 11-20

and hagiography $43-47$

as immersive experience $44,49,93$

hybrid forms of $80-81$

lived experience of $11,15-16,49,54$

technological development of $60,77,85$

cinema theatre $11,14,16-17,42,102,109,112,122$, 130-31, 136, 197

'cinesthesia' see Sobchack, Vivian Carol

Cistercian Order 22-23, 31, 34, 37, 57-59, 62, 127

Clairvaux, abbey 39

clergy 24, 223-24, 227, 231, 237-39, 248-49

'cultural clergy' 50-51

role-play of, online $237-39$

Cobb, Kacee 165

coenaesthesia 111-12, 143

Cologne 133

Communion see Eucharist, the

computer-generated imagery see technology

Constance, Thomas 171

Coquenunne 40; see also beguines

Le Corps du cinéma see Bellour, Raymond

Corpus Christi, Feast of 35n100, 38, 107, 132-33, 244n6

Commandments, the Ten 124

confession $154,177,225,248$
Confessions see Augustine

consubstantiation 119, 223

coresthesia 136-45

'cosmic mind', the 19-20, 47-48

Crucifixion, the see Passion, the

Crusade, the Fifth $15^{\circ}$

Crusade, the Albigensian $82-83,15^{2-53}, 155$; see also heresy

crying

of Ida of Nivelles 233

of Kim Kardashian West 173-74

of Margery Kempe 167, 170-73, 180

of Marie of Oignies 167, 170-73, 180

'ugly crying' 174

Cura sanitatis Tiberii 243

Cum de quibusdam mulieribus see Vienne, Council of

Czolgosz, Leon 80-83

Dark Knight, The 50, 89-91, 97-102

De aspectibus (Perspectiva; Kitāb al-manāzir) see Alhazen

Delehaye, Hippolyte 32

De institutione inclusarum see Aelred of Rievaulx

De lineis, angulis et figuris see Robert Grosseteste

De natura rerum see Thomas of Cantimpré

De secretis mulierum see Pseudo-Albert

democracy $82-83,101$

demons 35, 57, 87, 99, 133, 154-55, 169, 177

Denby, David 90

Denery, Dallas G. 108

Deploige, Jeroen $56-57$

Devil, the 99, 154-55; see also demons

Dialogus miraculorum see Caesarius of Heisterbach

Dibbell, Julian 194

disability 212-13

disease see illness

Displaced Person 111

Ditty, Jeanie 68-69

Ditty, Macy Grace 68

DNA 143-44

documentaries 9on119, 162-63

docu-tainment 51,165

Dominican Order 29, 35, 41, 132, 152, 159-6o, $167,171,206$

Douceline of Digne $74 \mathrm{n}_{32}, 251 \mathrm{n} 44$

Drax, Bernhard 198, 203, 241

Duke University 222

Dutch 25, 39, 151-52, 211-12

DVDs 42, 85, 92, 197

Dyer, Richard 61, 148-49

ecstasy $11,15,18-21,41,53,72-74,76-77,79,92$, 118-19, 121, 125, 131, 134-35, 147, 206-07, 210-11, $213,215,226,232-34,237,246,250,25^{2}$ and cinema 11-20 
and photography $73-76,79$

mutual experiences of 210-11, 214, 232-34

witnesses of 74-75

Edison, Thomas A. $80-81$

Elisabeth of Spalbeek 21-22, 33, 36, 39, 46-47, $92-93,211,243,246,250-5^{2}$

Elliott, Dyan 248,251

Ellis, Roger 169

Empire, Holy Roman 29, 156

England 40-41, 62, 65, 148n13, 149, 151, 168-69, 181

English, language 151, 168-70, 173

Enlightenment, the 18,110

Enslen, Johann Carl 65, 70

Etienne of Bourbon 159-60, 167

Eucharist, the 28, 107, 121, 125, 154, 205, 217, 237,

$239,248-49$

devotion to $34-35,78,132 \mathrm{n} 103$

medicinal power of 170

mystical $76,126-28,226-28,237$

online $223-26,226-27,238$

reception of, provoking ecstasy 74,76

sensuous visions of $126-28,226-28$

souvenirs of $137-38$

spiritual $224-25$

Europe 21, 40-41, 108ng, 147, 150, 169, 244

Evans, Ruth 168

Eve, biblical figure 177

EverQuest see gaming, online

Eve of Saint-Martin 38, 132-33, 207, 212-13, 207, 244

Execution of Czolgosz, with Panorama of Auburn Prison $80-83$

execution films $79-83$

Execution by Hanging, An 8o

Execution of Mary Queen of Scots, The 80

exempla $96,152,165,167$

and hagiography $43-44,69,81$

and reality TV 165

collections of $152,166-67$

execution films as $82-83$

'Ghost of Beaucaire' exemplum see Gervase of Tilbury

Marie of Oignies in 166-67, 169

extromission $61,107-08,115-17,123,141$

eye, the $20,25,35,52,61,66,75,80,83,92,103$, $109,113,115,117,119,122-26,131,134,136,193$, $216,237,247,254$

Facebook see social media

'Face of Christ Superimposed On An Oak Leaf' $65-67,70$

fairy tales 48

Fall, the 62

fanfiction $172-73,190-92$

$\operatorname{fan}(\mathrm{s})$

academics as $190-92$

as active media consumers and skilled crit-

ics 149-50, 172, 191; see also fanfiction

becoming celebrities $15^{8-61,187}$ dependence on celebrity object(s) 150, 154, 158-6o, 187

hagiographers as 61 ; see also Jacques of Vitry

historical emergence of $149-50$

of Jacques of Vitry 61, 160-61

of Kim Kardashian West 52, 183-84

of Marie of Oignies 61, 149-59, 187

Farley, Margaret A. 14-15

Fast and Furious 7 89n115

Feiss, Hugh $3^{2}$

Fetscherin, Marc 198, 211

film 50, 151; see also cinema

and emotions 200-01

and fallacy of immortality $84-85$

and reality $45-46,125-26,131$

and time $60-61,95,101,197$

as educative and entertaining $43-44,49-50$

body of $89,91,111,130$

composition of $60,77,86,89,103$

God as 43, 89, 91, 132, 134, 139

materiality of 127

real deaths in $80-83$

tropes and conventions in 45

film stock $84-85$

filters, photographic 179

Fiorenza, Elisabeth Schüssler 55

First United Church of Christ and Conference Centre in Second Life 194, 223

Flanders 40, 56n189

Flemish, language $38,15^{2}, 212$

Florival (Bloemendaal), monastery 31

Folda, Jaroslav 189

Folger, Robert 117

forums, online 201

Fradenburg, Louise 142-43

Frascati 28

France 27 (Fig. 2), 29, 36, 40, 82, 148n13, 151, 160,205

Franco of Archennes 54

Frauenfrage, the 27

Frazier, Brianna 186

French, language 25, 38, 57n19o, 151-52, 211-13

Fulk of Toulouse $25 \mathrm{n} 48,15^{2-54}$

Galen 87

gaming, online 215,221

and Second Life 198, 204, 235

EverQuest 235-36

World of Warcraft 236

Gerald of Wales 245, 252

Gerlach of Houthem 54

German, language $15^{2}$

Germano, William 52

Germany 27 (Fig. 2), 40-41, 46n16o, 65, $90 n 119$, 151

Gervase of Tilbury

'Ghost of Beaucaire' exemplum 88

Otia imperialia $83,244 \mathrm{n} 4$

Ghent 25 
'Ghost of Beaucaire' exemplum see Gervase of Tilbury

ghosts 67-69; see also paranormal, the

GIFs 95

Giles of Nivelles $29 n 55$

Gilleir, Anke 40

Gobert of Aspremont 54

God

as film $42-43,89,91,126,130-31,134-35$, 137,139

as index 75

as light $122-23,219$

as originator of celebrity 147

as photographer 77

as projectionist 122

as projector $85-86,89,112,122-25$

as viewing subject $15^{-16}, 122-24,135^{-3} 6$

of Photoshop 69

of TV 50

Godfrey Pachomius 54

Godfrey the Sacristan (of Villers) 54

Goldwyn, Samuel 147

Goodman, Antony 169

Google 179-80, 241

Gospel of Nicodemus 243

Goswin of Bossut 22, 38-39, 55, 57-58

Gregory IX 43, $15^{\circ}$

Grosseteste, Robert 115, 125n69

De lineis, angulis et figuris 113

Guiard of Cambrai 132

Guiard of Laon 38

Guido of Nivelles 29

hagiography

and book(s) of life $32-33$

and celebrity production $52,148-49$

and photography 69-70

and relationship to objective reality 29,61 , $133,164,240$

as authentic $46,69-70$

as cinematic $12,20-21,43-47,80-83$

as entertaining and instructional $43-44$,

49-50, 69

as exemplary $80-83$

as media 11-14

as panopticon 156

as pop culture 47

as textual relic(s)/reliquaries $187,190,253$

Bollandists' definition of $32-33$

problem of mediation in $12,147-49,15^{8}$, 160,168

repetition in $44-45$

reputation of, in academia 47

temporality of $81-82$

Hahn, Cynthia 252-53

Hainaut 30

hair $162-64$

Harari, Yuval 63

Harding, Wendy 182-83 hardware $85,117,199,204 \mathrm{n}_{51}, 221,234,240$

computers 85, 92, 194-96, 203, 207, 209, 219, 221, 241

DVD players 92

internet connection 199, 204n51, 207, 221, 240-41

iPads 42

robotics 222

smart devices $50,92,178,182$

Henneau, Marie-Elisabeth 37

heresy $121,169,187$

anarchy as 83

and purgatory $82-83,154-55$

of Catharism $82-83,152-55$

of Free Spirit 30

of Lollardy 174

Herkenrode, monastery 37

Hessle 169

Hilton, Paris $176,178,181-82$ Simple Life, The 176,178

Hilton, Walter 180

Historia occidentalis see Jacques of Vitry

Hitchhiker's Guide to the Galaxy see Adams, Douglas

Hollywood 162, 181, 203

Classic Hollywood, celebrity production in $51,147,149$

Hollywood, Amy $56 \mathrm{n} 188$

Holtmeier, Matthew 200

Holy Feast and Holy Fast see Bynum, Caroline Walker

Holy Land, the 150

holy men

mystical visions of $233-35,249$

of Liège, as corpus $54-55$

recent scholarship on $55-59$

holy women

and beguines $30-36$

and celebrity $147-92$

and monastic life 34-35, 214

and politics of visibility 74, 104, 133, 156, $25^{2}$

and Virgin Mary 136

antagonized by lay community 35-36, 214

as anchoresses/recluses $23,33,40,213$

as collective audience $40-43$

as collective spectatorial body $131-36$

as conduits for God 127-28, 130, 133-35, 156-58, 220

as exceptional 166

as exemplary 43-44, 46-47, 81-83, 153; see also exempla

as living saints 46

as photographic $74-77,105$

as screens $124-25,133,139$

as specular objects $74-76,104$

as spiritually useful $75,104,157-5^{8}$

as target of slander $34-35,155$

as 'vernacular photo-objects' 105

as virgins 22-23, 32-33, 37 
as wives and mothers $23,33,151$ conflict with Church $30,76,156,186,214$ descriptors for 32

devotion to Church 154, 227-28, 240 geographical distribution of $40-43,156$ lifestyle of 24-25 manuscript tradition of $39,53-54,140-41$, 151,187 masculinization of 58 need for Church 24, 51, 240-41, 243, 249-50 need for men (clergy and hagiographers) 28-29, 44-46, 51, 150, 155-56, 187, 237, 248-49

needed by Church 43-44, 46-47, 69-70, $82-83,121,132-33,152-53,155,232,243$, $247-49$ needed by men (clergy and hagiographers) $43,147-50,158-59,162,234,249$ of Liège, as corpus 21-40 terminology for biographies of $32-33$ visual acuity of $125^{-2} 8$

Honorius III 29, 156

Horak, Jan-Christopher 85

Hornbach Sanctuary, the 144

horror, film genre 46n16o, 48, 112

Horsfall, Debbie 177

Howells, Richard 147

Hugh of Floreffe 23, 134-35

Hugh of Saint-Cher 132

Hugolino of Segni see Gregory IX

Humbert of Romans 159-60, 167

Humiliata 40; see also beguines

Hutchings, Tim 238

'iCloud hack', the 178-79

icons $53,62,220,243-47,253$ and celebrity $147,162-63,179,247$

Ida of Léau 21-22, 31, 33-34, 39, 46, 73-74, 76

Ida of Louvain $21-22,33,35-36,45,58,74-75$, $135,193,234,237-39$

Ida of Nivelles 21-22, 33-35, 37-39, 55, 58, 72, 206, 210-11, 232-33, 246-47

illness $25,35,56 \mathrm{n} 188,75,78,135,163,177,224$, 238,243

leprosy 34, 102-04, 140-41, 151, 219, 248

Parkinson's disease 221

imitatio Christi 58, 75, 228, 230

Immonen, Visa 251

impression

holy women bearing, of Christ 74-75, $245-46$

in medieval optical theories $61,107,136$

Incarnation, the $73,119-20,122,230,245$ and time $73,95-96$

index, the $60,65,68,70-71,74-75,142,245$

indulgences $97-98,155,187,244$

Innes-Parker, Catherine 20

Innocent III 155, 206, 244

Instagram see social media instant messaging, online 196, 207

internet, the see also 'produsage'; technology and content distribution 50-51, 199, 240-41 and fandom 149-50, 191

as religious space $62-63,194-95,220-21$; see also Second Life, religion in

as Web 2.0 149, 199, 203, 240

intromission $61,107-08,114-17,123,141$

iPads see hardware

Isabelle of Huy 31

Islamic State (ISIL; ISIS; Daesh) 82

Italian, language 151

Italy 40-41, 188-89 (Figs. 10-11), 237

Jacob of Maerlant $15^{2}$

Jacobus of Voragine 243-44

Jacques of Troyes see Urban IV

Jacques of Vitry 23-24, 28-29, 32, 34, 38, 40, 42-43, 54, 61, 70, 147-51, 156-61, 163-64,

$166-167,186-90$

Historia occidentalis 57

Sermones ad status 40

Jansen, Sharon L. 174

Jay, Martin 109

Jean of Vignay 152

Jefferies, Diana 177

Jenkins, Henry 172, 191

Jerusalem 13n9, 169, 190, 243

'Jesus Cross with Animation' see Amat, Trigit

Jews 37, 104

Joan of Flanders $56 \mathrm{n} 189$

'John' (SL Resident) 237-38

John XXII 30

John the Baptist 169, 206

John of Cambrai 133

John of Cantimpré $54-55$

John of Caulibus 13n9, 193-94

John the Evangelist 206

John of Lausanne $38,133,244 \mathrm{n} 6$

John of Liroux 28-29, 206

John I of Mont-Cornillon 35, 213

John of Nivelles $28,29 n 55$

John of Willambroux 151

Joker, the 90-91, 97-101; see also Ledger, Heath

Jongen, Ludo 36

Jordan of Saxony 206

Julian of Norwich $78 \mathrm{n}_{54}$

Juliana of Mont-Cornillon 21, 23, 31, 35, 38, 72, 92, 118-19, 128-29, 131-33, 212-13, 231-32, 240, 244

Jutta of Borgloon 38

Kandiyoti, Deniz 249-50

Kardashian, Khloé 183

Kardashian Konfidential 183

Kardashian, Kourtney 173, 183

Kardashian West, Kim

and celebrity production $175,179,181-86$

and social media $181-85$ 
criticism of $51^{-} 5^{2}, 174-75,185^{-8} 8$

robbery of, in 2016 184-85

Selfish $178-79$

sex-tape of 178

subjectivity of $178-79,183,185-86$

'ugly crying' of $173-74$

use of selfies $178-80,182-83$

Kay, Sarah 81, 140

Keefer, Zachary 68

Keeping Up With the Kardashians 173, 176, 178, $183-84$

Kempe, John 169, 174

Kempe, Margery 21, 41, 51, 167-77, 179-82, 192

Kerkom, monastery 34, 212

King, Barry 199-200

King, Margot H. 26

King's Lynn 169

Kripal, Jeffrey J. 19-21, 47-48

kyriarchy, the $55^{-59}$

Lachey, Nick 178

Laon 244

Lateran IV, Council of $87-88,248$

language(s)

inclusive 59

miraculously traversing barriers of 38 , 211-12

mystical 156,212

vernacular 25, 57n19o, 105, 151-52, 169-70, 205, 213

Larrington, Carolyne 169-70

Latin $21,39,53,105,139,151-52,173,205,213$

Latour, Bruno 59-60

Lattemann. Christoph 198, 213

Lauwers, Michel 36

Ledger, Heath 89-92, 98-101

Léau 31

Legenda aurea see Jacobus of Voragine

Le Goff, Jacques 93

Leicester 169

Lepanto, archdiocese of (in Second Life) 238-39

leprosy see illness

Lewis, Katherine J. 168, 181

Liège, city 25

Liège, diocese of 22-24, 28 (Fig. 3), 29, 31n64, 37, light $132-33,154,15^{6}$

and $\sin 124-25$

emitted from eyes of holy women 122-23

God as $122-25,219$

God as projector of $112,122-25$

in paranormal visions $19-20$

in photographic process $60,65,71,74$

in theories of Roger Bacon 114, 116, 124-25

Lille 211

Linares, Kevin 235

Linden Lab 194, 196, 202, 211, 241

liturgy 91-96, 157, 180, 189, 237

Lollardy see heresy
Lombardy 40

Loon 38

Lord's Prayer, the 194

Lotharingia 160

Louvain 53

Dominican monastery in 29,161

Low Countries 25, 26-29 (Figs 1-4), 30, 41, 151

'low culture' 48, 50, 104-05, 112

'Luke' (SL Resident) 239

Lumière brothers 77

Lutgard of Aywières 21, 23, 33, 35, 37-39, 46, 55, $57,94-95,156,161,206,215,251 n 49$

Lyon, Second Council of 88

Maagdendaal, monastery 210, 232-34

machinima 202-03, 241

Malaby, Thomas M. 216

male gaze $15,108,110$

manuscripts $37,39,53-54,56 \mathrm{n} 190,112$

abrasions on $139-42$

and 'agape-ic encounter' 54

and coresthesia 143

annotations on $142-43$

as body $54,138,140-41,144-45,187-90$

as body of Christ 138

haptic engagement with 54, 112-13, 136-45

modification of, by owners 137

Margaret of Castello $78 \mathrm{n}_{54}$

Margaret of Flanders $56 \mathrm{n} 189$

Margaret of Magdeburg 40

Margaret of Ypres 21, 23, 35-36, 38-39, 55, 72, $125-27,161,215,226-28$

María de Santo Domingo 41

Marie de France 97

Marie of Lille 211

Marie of Oignies 21, 23-25, 29, 32-34, 36-37, $39,41-44,55,63-63,70,147,148 \mathrm{n}_{13}, 150-59$, 166-67, 169-73, 187, 192, 198, 206, 251-52

Marks, Laura U. 110-11, 221, 223

marriage, chaste $23,36,151,169$

Marshall, Paul 19

Marshall, P. David 153

martyrdom 14, 20, 81-82, 139, 155, 230

Mary Magdalene 72,181

massively multiplayer online role-playing games (MMORPGs) see gaming, online

'Matthew' (SL Resident) 237-38

Matthew Paris 40, 246

McDayter, Ghislaine 190

McDonagh, Maitland 99

McDonnell, Ernest W. 147

McGinn, Bernard 21, 43-47

McKinley, William 8o-83

Mechelen 53

media

and identity production 52, 198-99; see also celebrity

as intrinsic to religion $12-13$

hagiography as 11-14 
immersive properties of $13,49,93$

liveness of 197-98, 205-06

models of production and consumption $5^{0-51,183,203-04}$

multimodality of $13,245-46$

media, digital 50, 6o, 82, 95, 197, 199

and digitization 85

and disruption of traditional consumption models 203-04

and perception of incorruptibility 85

streaming of 42, 50, 197

Meditaciones vite Christi see John of Caulibus meditation, manuals for $193-94$

memes, online 174,185

Meyer, Birgit 12-13, 48n171

Middle Ages, the

and modern era 11, 19-21, 47, 59-6o, 142-45, 191-93, 220-21, 230, 253-54

as colonialist Other 253

optical theories of 107-17, 136-37, 215

temporal frameworks of 71-73, 91-97

Middle East, the 100

millenarianism 62

Mills, Robert 108, 110

miracle(s)

etymology of term 65

of photography $65^{-67}$

religious $37,44,46,61,86,96,135,137,147$, $163,187,217,243,251$

Le Mirouer des simples ames see Porete,

Marguerite

mirrors $65,115,182,253-54$

Misfits, The 89n115

Misonne, Daniel $3^{2}$

Mitchell, Katie 73

Mitchell, W.J.T. 13

mitre, parchment $188-90$

monks 54, 58-59, 72, 96, 127, 174, 188n19o, 237-38

Monroe, Marilyn 162-63

Montoya, Alicia C. 40

More, Alison 57

Mormonism see Church of Jesus Christ of Latter-day Saints

Mors Pilati, 243n3

Moses, biblical figure 123-24, 134

movie see film

movie theatre see cinema theatre

Mulder-Bakker, Anneke B. 32-33, 40, 47, 54, 56

Mulvey, Laura $15,59,71,87$

Mumler, William H. 67-68

mummification 77

museum, the $104-05,188$

Namur 28n $52,31,38$

National Public Radio 186

Nativity, the 193

Na'vi, the 199-202

'Navitars' 201 (Fig. 12), 202-204 neomedievalism 6o, 142; see also Middle Ages,

the

Netherlands, the 40

neurons, mirror 221

New Catholic Encyclopedia 164

Newman, Barbara 21, 36, 54, 56, 121, 204

Newman, Martha G. $5^{8}$

New York 80

New Yorker, The 90

Neytiri 200

Nicholas of Cantimpré 164

nightmares 48

Nivelles 28n2, 150-51

Njus, Jesse 211-13

Norbert of Xanten 27

Norfolk 169

Norse, language $15^{1}$

Norwich 171

nuns $27,30-31,33-35,57,74,76,79,94,104-05$, 206

ocularcentrism 108-10

Odilia of Liège $35^{-3} 6$

Oignies $147,25^{2}$

beguinage of $28 \mathrm{n}_{5} 2$

church of $15^{\circ}$

priory of $28,29 n 53,149-51,188,25^{1}$

Opus majus see Bacon, Roger

orality $182-83$

Oscars, the see Academy Awards, the

Otia imperialia see Gervase of Tilbury

Other, the 20, 253

Oxford English Dictionary, The 214, $220 n 118$

Pacific Time 207-08

Pan-American Exposition, the 80

Papebroeck, Daniel 164

Papelarda 40; see also beguines

paraplegia 199, 222

parchment 138, 140-41, 188-90; see also skin; vellum

Parc-les-Dames (Vrouwenpark), monastery 37

Parkinson's disease see illness

Passion, the $58,75,92-93,118-19,215,228-30$, 246,250

Premonstratensian Order 27, 234

Pandora 199-200

Pandora sims, in Second Life 200, 202

panopticon, the $156,182,254$

paranormal, the $19-20,47-50,63,65,67 \mathrm{ng}$; see also ghosts

Paris 28n52, 38, 77, 107, 132, 147, 150, 184, 186

Paris Fashion Week 184-86

patriarchy, the $55^{-5} 5^{6}, 174$

and feminist scholarship 56 ; see also

kyriarchy, the

and modern women $165^{-} 66,181-82,185^{-86}$, 254

and women's humanity $185-86$ 
as panopticon 182,254

bargaining with $236-37,249-53$

beauty standards under $165-66,181-82,236$

Pavés, Ken 162-63, 165, 167

You Are Beautiful 163

Pearce, Celia 213-15

Peter of Villers $54-55$

Peucker, Brigitte 127

Pheasant-Kelly, Frances 100

Philip of Clairvaux 22, 46, 92, 211, 243, $25^{\circ}$

Philip III of France 36

Philippine of Porcellet $74 \mathrm{n}^{2}$

photogenic drawing 65,70

photography 50 ; see also Barthes, Roland;

index, the; selfies

and affect 104-05

and death $77,91,103$

and digital manipulation 68-69; see also

filters, photographic

and divinity $65^{-69}$

and hagiography 69-70

and photographic function $70-71$

and promise of salvation 73

and reality $52,65-69,70,74-75$

as miraculous $63,65-67$

haptic engagement with 105

invention of 65

populist, as vernacular 104-05

spiritualist $67-69$

temporality of $60,67,70-71,73,77,89$, 103-04

photo-montage 65,70

Photoshop 67-69, 173

Pierre of Nemours $15^{\circ}$

pilgrimage 13n9, 133, 169, 190, 211

Pixar Animation Studios 85

Polaroid camera see camera

pop culture

and 'cultural clergy' 50-51

and hagiography 47

and populist photography 105

as container for mysticism $48-5^{\circ}$

as 'low culture' $5^{0}$

as product of 'cultural laity' $50-5^{1}$

temporal mode of 95

Porete, Marguerite 30

pornography 20, 112

La Poste 77

post-Pandoran depression 200-01

preacher(s) $26,107,152,166,171,173$

Jacques of Vitry's career as $149-50,157-60$, 249

women as $154,15^{6-}-57,25^{\circ}$

Presentation, the 170

Price of Beauty, The see Simpson, Jessica

'produsage' see Bruns, Axel

projector, the $20,44,77-78,85-86,89,103,112$, 122-25

prophecy $20,35-37,72,94,132,155,159,249-5^{0}$
Pseudo-Albert 87

Pseudo-Bonaventure 193

'punctum', the see Barthes, Roland

purgatory

and communion of saints 205

and heresy $82-83,154-55,248$

and the purgatorial body 88-91, 103

doctrine(s) of $87-88,97,248$

experienced on earth 78

intercession for souls in 97, 205, 248

reality of $82,87,154-55,205$

temporality of $89,96-102$

Radde-Antweiler, Kerstin 234

Le Radical 77

La Ramée, monastery 31, 35, 37, 76, 233

Ratio recta see John XXII

Ray J 178

Raynaud, Dominique 110

reader(s)

and imagination $45,70,86$

as agent of reanimation 81

as offscreen $132-33$

as 'photographed photograph' 75

as Veronica(s) 247

direct address(es) to $75,94-95,130,135$, 166, 247

following gaze in text $121-22$

haptic interaction with manuscript 13,54 , $105,136-45,206$

inhabiting narratives 206,247

instructed by vitae 43-44, 46-67, 103-04, 166

trans-temporal community of 141-43, 145

reading

as seeing $120,136-37,188$

as tactile experience $137-42$

reality $\mathrm{TV}$ see $\mathrm{TV}$

real life $45,79,178-79$

as in life offline 211, 213-14, 218, 221, 233-35, 238-39

relics $62,150,187,190,212,246,25^{1-} 5^{2}$

reliquaries $252-53$

repetition

and cinema 45, 84, 93, 197

of motifs in hagiography $44-46$

resurrection

and cinema $77-78$

and the glorified body 86

Catholic doctrine(s) of $78-79,83$

of Christ 84, 94-96

of Christina Mirabilis 77-78, 86-87, 95-96

vs. resuscitation $83-84,87$

Ribaucourt, Colette 165

Rojek, Chris 176

Rolle, Richard 180

Rome 131, 150, 169, 205, 207, 243-44, 246, 252

Roosevelt, Theodore 83

Rudy, Kathryn M. 138 
saints 190, 206; see also holy women

saints, communion of 204-15

accessed in visions 204-07, 232

and language 211-12

and ontology of liveness 205-06

in Second Life 209-11, 213-14

location of 206-07

temporality of 206-07, 216

St. Birgitta of Sweden 148n13, 176, 18 1

St. Boniface of Lausanne 38

St. Catherine $72,181,206$

Saint-Catherine, monastery 35,85

Saint-Denis, collegiate church 29

St. James 150

St. John 217

Saint-John, collegiate church 28

St. Margaret 81-82, 139-141

Saint-Martin, church 38, 132

Saint-Nicholas-of-Oignies, church 28

Saint Patrick's Purgatory see Marie de France

St. Paul 84, 131, 205, 207, 219

St. Peter 131, 144, 207

Saint-Peter, basilica 244

St. Philip 150

Saint-Sepulchre, hospital 29

Saint-Spirito, hospital 244

St. Veronica see Veronica

Saldana, Zoe 200

Salzinnes, abbey 31

Sanders, Theresa 81

Santiago 169

Saxony 40

Scheepsma, Wybren 36

Schleif, Corine 144

Schneider, Athanasius 238

science fiction, film genre $46 \mathrm{n} 16 \mathrm{o}$

Sconce, Jeffrey 181-82

screen(s) 124, 167, 176, 252

Christ as 139

cinema screens $14,25,48,61,80,103,110$, $112,122-23,126,128,130-31,133,135,200$

computer screens 195, 202, 221

desire for 200-02; see also Sobchack, Vivian

Carol; spectatorship, embodied

holy women as $125-26,133,138,252$

narratives as 137

second screen(s) 124-25

sky as 128

text as 132

Scully, Jake 199, 202

Second Life see also avatars; machinima; 'produsage'

and communion of saints 206-11

and disability 212-13, 221-22

and heresy 231,239

and identity production $5^{2}$

and language 211

as collaborative performance $198,203-04$

as private commercial entity 241 author's research study in 196-97, 208-09, 212-14, 217-19, 223-25, 231, 236-39, 242

churches in 194, 208-09, 209 (Fig. 13), 212-13, $220,223,225,231,237-39$

clerical role-play in $237-39$

Eucharist in 223-27

imitatio Christi in 228-30

interactivity of 197-98, 205-06, 213

meaningful community in $211-14,231$

overview of $195-96$

prayer in 194, 209 (Fig. 13), 210, 216, 225, 242

religion in $52,62,194-97,198-10,212-14$, 217-29, 222-26, 228-30, 238-39, 242

role-playing Avatar in 202-04

Second Life Marketplace 211, 228

Second Life Time 207-08

Second Looking, the 73

selfies see Kardashian West, Kim

Selfish see Kardashian West, Kim

sensorium, medieval 107-09, 136-37, 157-58

Serenade, Fran 221-22

Sermones ad status see Jacques of Vitry

sickness see illness

Silicon Valley 63

Simon, abbot of Foigny 206

Simon of Aulne 54, 56-57

Simons, Walter 30, 37

Simple Life, The see Hilton, Paris

Simpson, Jessica

as exemplum 165

as legitimate celebrity 51,163

construction of celebrity 181; see also Pavés, Ken

Jessica Simpson: A Public Affair 162

Price of Beauty, The 163, 165-67, 181

singing, mystical $156-5^{8}$

Sint-Truiden

abbey of 39,86

town of $35,78,85,244$

Sobchack, Vivian Carol 59, 80

and 'cinesthesia' 111-12, 118-19, 123, 125, 143

and ecstatic cinema $16-18$

and embodied spectatorship 110-12, 118-19, $123,125,135,138-30,143$

and 'sensual catechresis' 128-30, 135

skin $19,57,141,246$

avatar skins 236

of film 130

of film spectator 112

of manuscript readers 140

parchment as $137,140-41,144,190$

smart devices see hardware

snapchat see social media

snuff, film genre 81

social media 51, 150-51, 199

and orality 183

Facebook 183, 241

Instagram $183^{-84}$

Snapchat 184 
Twitter $183-85$

YouTube 174, 241

software $63,85,202,204 n_{51}, 211,221-22,234$,

240-41

Spadaro, Antonio 194

Spain 41

Spearing, A.C. 168

species $61,107-08,113-17,122-23,136$

spectator(s) 11, 15, 17-18, 45, 49, 84, 90, 92-93,

100-02, 110-12, 133, 245, 253 see also 'agape-ic

encounter'

academic 44,112

as producers and performers $203^{-04}$

bodily responses of $61,112,128-31,134,137$; see also spectatorship, embodied

emotions of 111, 128, 131, 200-02

engagement with screen $14,17,49,93,110$, $118,125,128-31,200-02$

following camera's movements $121-22$

of execution films $80-81,83$

'ordinary' 50, 112

shared experiences of 41-42, 93, 197

spectatorship

contexts of 41-43

embodied 6o-61, 110-12, 127-31, 134-36; see also Sobchack, Vivan Carol

identification with narratives onscreen 61 , 200-01

temporality of cinematic 93, 101-102, 197

Speculum ecclesiae see Gerald of Wales

Speculum historiale see Vincent of Beauvais

spiritual, as opposed to religious $18,48,220$

Spryngolde, Robert 168

Staley, Lynn 168

star see celebrity

stardom see celebrity

Starkey, Kathryn 108, 136-37

Star Trek 212

stasis

of death $85,87,91$

of holy women in rapture $73-76,78,131$, 246,250

of photography $73,77,103$

Stevens, Dana 100

stigmata see blood

Strieber, Whitley 19-21, 47-48

'studium', the see Barthes, Roland

Summa theologica see Aquinas, Thomas

Sunny Jo 68-69

supernatural, the see paranormal, the

Supplement to Marie of Oignies' vita see

Thomas of Cantimpré

Sutton, Damian 71, 73

Sweden $40 n 143$

Swedish, language $15^{1}$

synaesthesia 13,15, 111-12, 126, 128-29, 143

Szerszynski, Bronizlaw 62-63
Taavitsainen, Jussi-Pekka 251

Talbot, William Henry Fox $65^{-6} 7,70$

talent shows see TV

talk shows see TV

tears see crying

technology 12, 6o; see also internet, the;

hardware

and disability 212-13

and media consumption 50, 91-92, 198-99, 203-04

and religion $62-63,214,220-21$; see also

Second Life

obsolescence of 85

of computer-generated imagery 202

of performance capture 199-200

physical and emotional responses to 221-22

Teeman, Tim 99

terrorism

of demons 99

of Islamic State 82, 99

of the Joker 91, 97-101

post-9/11 99-101

theatre $49,197-98$

Thérouanne, diocese of 23,28 (Fig. 3 )

Thomas of Cantimpré 22-23, 29, 38, 46, 54-55,

$61,70,79,86,87,94-95,161-65$

Bonum universale de apibus 152, 164

De natura rerum 164

Supplement to Marie of Oignies' vita 38, 55, 160,164

Thuin 234

time

and cinema $61,77-78,89,93,95,102$

and hagiography $81-82$

and mystical visions $60-61,71-73$

and photography $60,67,70-71,73,86,89$ 103-04

and the medieval Church 93-94

in communion of saints 206-08, 216

'in real time' 211, 213-14

in Second Life 207-08, 216

of liturgy 91-96, $25^{\circ}$

of medieval narrative 93

of purgatory 96-102

linear vs. polytemporal 59-6o

looping of 94-95

medieval temporalities 71-73, 91-97

mortal time 72-74, 93, 95, 97

sacred time $71-72,74,93$

secularization of 102

Toy Story 85, 199

Transiturus de hoc mundo see Urban IV

transubstantiation 126-27

Trent, Council of 224

Trinity, the 119-20, 127, 247

Troyes, diocese of 38

Trump, Donald 179

Tusculum see Frascati 
TV 50, 158, 165-66, 197, 205, 212 reality TV $51,150,162-63,165-66,173-76,178$, 181-83, 185; see also docu-tainment talent shows 158 talk shows 162

Twitter see social media

\section{United Church of Christ 194, 223-24}

United Kingdom 217

United States of America 83, 162, 179-8o, 209, 213-14, 218, 220, 223, 231, 236-38, 242, 247n26

Urban IV 132-33, 244

Transiturus de hoc mundo 132

\section{València $41 \mathrm{n} 148$}

Vatican, the 194, 223-24

Vatican Secretary of State, the 194

veil(s) 37, 76, 124, 243-44, 252-53; see also

Veronica, icon

vellum 137, 143-44; see also parchment; skin

Veronica, icon $243-45,252$

and St. Veronica 243-44

holy women as $62,243,245-47,253-54$

indexicality of 245

modern women as 254

popularity with holy women $53,244-45$

reader(s) becoming 247

textual tradition of $243-47$

VHS 197

Vienne, Council of 30

Villers, abbey 38-39, 54-55, 57-59

Vincent of Beauvais 152,169

Vindicta Saluatoris $243 n 3$

Virgin Mary 188

as container of Christ 136

visions of $37,72,134,169,193,206,212$

virgins, holy 22-23, 32-33, 37, 40, 177, 251n 49

virtual environments, online 6o, 62, 197-98, 213-14; see also Second Life

visions, mystical

and earthly agency $24,132,249$

and the paranormal $19-20,47^{-} 5^{\circ}$

and time 60-61, 71-74, 206-08

and virtuality 193-94, 211

as authentic $125^{-26}, 130$

as immersive and interactive 193-94, 206

as means to bypass Church 230-32, 237, 239

as mutually constitutive $123-24$

dependence on earthly realm 240-41

fusing with object of 112, 118-19, 126, 128-30, 230-31, 241

materiality of $19,23-24,74-75,118,123$, 126-31, 215, 222, 226-28

of men $233-35,249$

of purgatory $96-97,205$

offering personal relationship with divinity $76,158,230-31,239$

providing theological knowledge 119-21, $123,126,131-32,156-58,226-27,231-32$ reciprocal 210-11, 214, 232-34

space accessed in see saints, communion of witnesses of 74-76, 124-25, 130-35, 207 vision

and divine truth 109-10, 114, 122-23, 126

and feeling (physical and emotional)

107-09, 111-12

and gender 110-11

medieval theories of $61,107-10,113-18$, 136-37, 214-15

mutuality of 107-11, 115-17

piety of $125^{-26}$

power dynamics of 14-16, 19-20, 108, 110-12, 116-18, 123-24, 136, 216; see also male gaze

vita mixta $25,133,150,155$

vocalization, mystical 128-29, 131, 207; see also

singing, mystical

voice chat, online 196, 207

Voss, Christiane 111, 125

Wace 81

Wagner, Rachel 195

'Wait Wait...Don't Tell Me!' see National Public Radio

Walker, Paul 89n115

Walmart 163

Watson, Nicholas 12, 190-91

Web 2.0 see internet, the

weepies, film genre 112

West, Kanye 173n125

Who's Who in Christianity 180

Wickliffe, Conway 91n121

Willambroux, leprosarium 29, 151

William of Dongelbert 39

William of Ryckel 39, 212

Williams, Linda 112

Windeatt, Barry 168

Wogan-Browne, Jocelyn 37

women see also patriarchy, the acceptable womanhood $181-82$ and Eucharist 226

and heresy 154

and production of femininity 179, 236

and public sphere 174

and $\sin 177$

commodification of $186-87$

dearth of in 1980 os medievalist canon 180

female celebrities as hyperreal of 165-66, 181-82; see also Simpson, Jessica;

Kardashian West, Kim

harassment of, online $236-37$

multiple social roles of 178

'real women' 162, 186, 254

World of Warcraft see gaming, online

Worthington, Sam 199-200, 202

$\mathrm{X}$ factor, the 158,247

$X$ Factor, The 158 
Yee, Nicholas 236

Yolendis, nun in Aywières 206

Yoshikawa, Naoë Kukita 169-70

YouTube see social media

Yvette of Huy 21, 23, 33-34, 37, 39, 127, 134-35, 217
Zeger of Lille $35,38,72,227$

Ziegler, Joanna E. 53

zombies $77-78$ 